Prepared in cooperation with the South Carolina Department of Transportation

\title{
Development and Evaluation of Live-Bed Pier- and Contraction-Scour Envelope Curves in the Coastal Plain and Piedmont Provinces of South Carolina
}
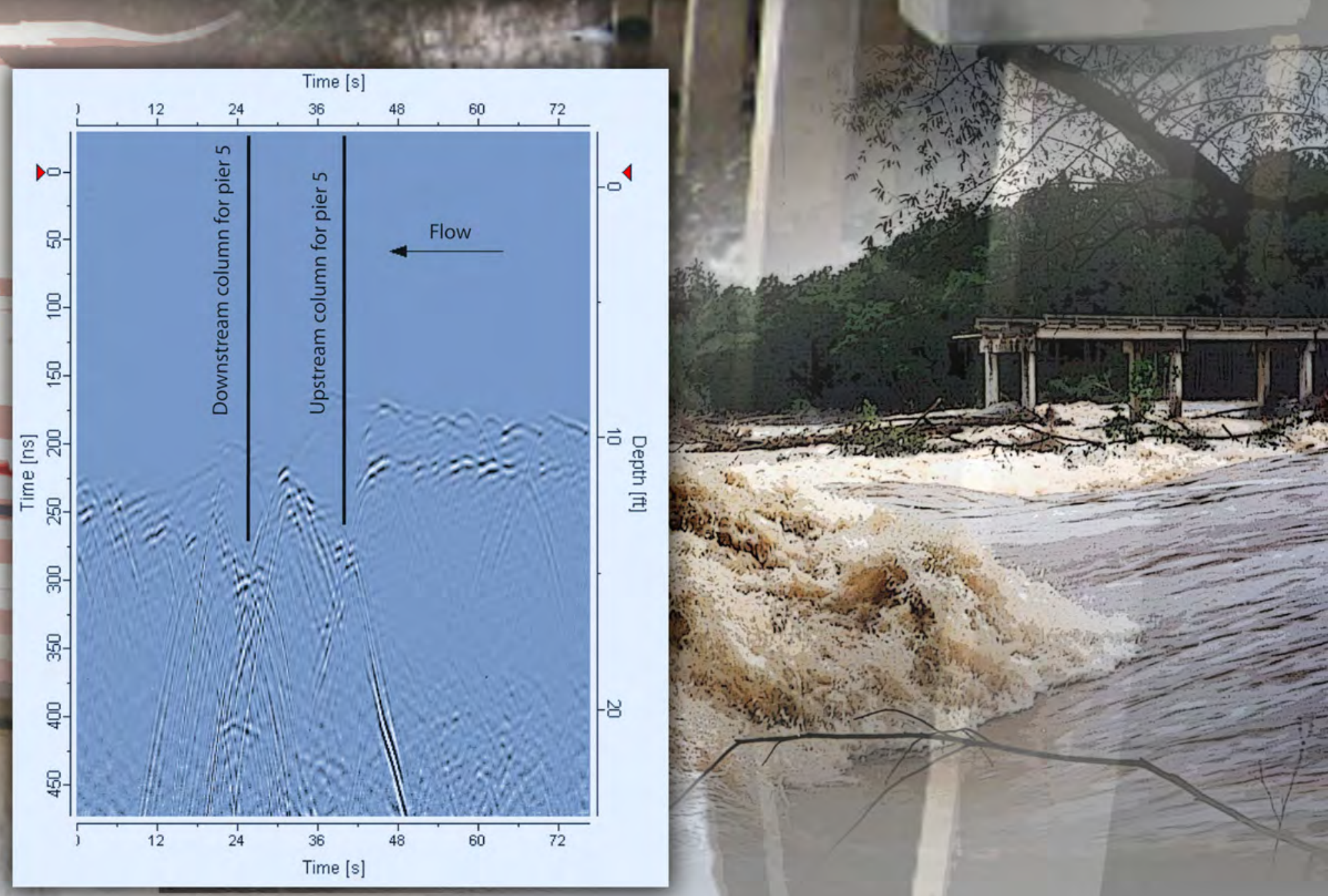

Scientific Investigations Report 2009-5099 


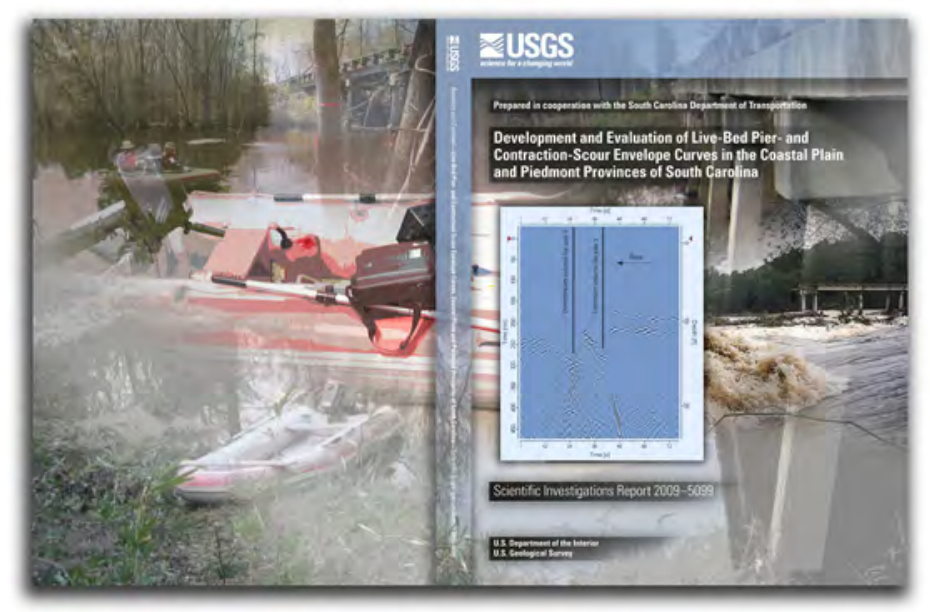

Cover photographs taken by the USGS South Carolina Water Science Center, 1995-2009. 


\section{Development and Evaluation of Live-Bed Pier- and Contraction-Scour Envelope Curves in the Coastal Plain and Piedmont Provinces of South Carolina}

By Stephen T. Benedict and Andral W. Caldwell

Prepared in cooperation with the

South Carolina Department of Transportation

Scientific Investigations Report 2009-5099 


\title{
U.S. Department of the Interior \\ KEN SALAZAR, Secretary
}

\author{
U.S. Geological Survey \\ Suzette M. Kimball, Acting Director
}

\section{U.S. Geological Survey, Reston, Virginia: 2009}

\begin{abstract}
For more information on the USGS — the Federal source for science about the Earth, its natural and living resources, natural hazards, and the environment, visit http://Www.usgs.gov or call 1-888-ASK-USGS

For an overview of USGS information products, including maps, imagery, and publications, visit $h$ ttp://www.usgs.gov/pubprod

To order this and other USGS information products, visit http://store.usgs.gov
\end{abstract}

Any use of trade, product, or firm names is for descriptive purposes only and does not imply endorsement by the U.S. Government.

Although this report is in the public domain, permission must be secured from the individual copyright owners to reproduce any copyrighted materials contained within this report.

Suggested citation:

Benedict, S.T., and Caldwell, A.W., 2009, Development and evaluation of live-bed pier- and contraction-scour envelope curves in the Coastal Plain and Piedmont Provinces of South Carolina: U.S. Geological Survey Scientific Investigations Report 2009-5099, 108 p. 


\section{Contents}

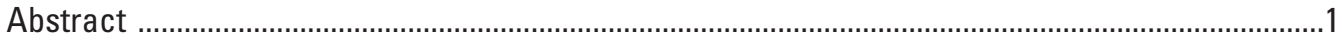

Introduction

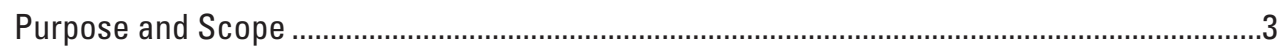

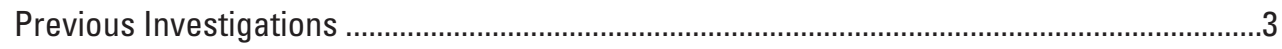

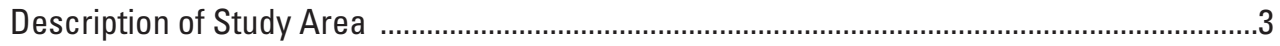

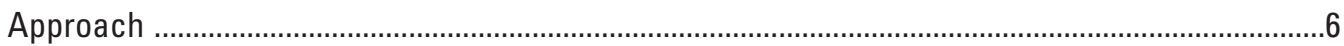

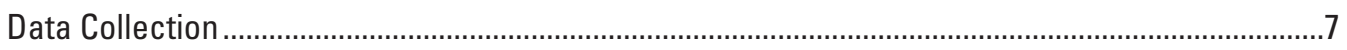

Live-Bed Scour Conditions ......................................................................................................

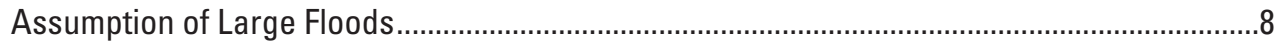

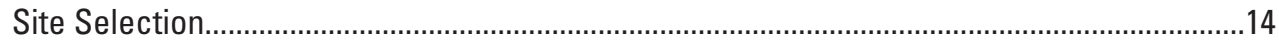

Techniques for the Collection and Interpretation of Field Data ............................................14

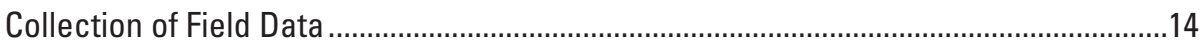

Interpretation of Field Data ......................................................................................

Development of the Predicted Bridge-Scour Database …….....................................................18

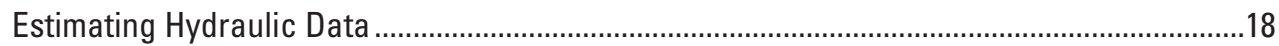

Estimates of the Maximum Historic Flows ...........................................................................18

Predicted Live-Bed Pier Scour ...........................................................................................19

Predicted Live-Bed Contraction Scour ...................................................................................2

Development of the South Carolina Live-Bed Pier-Scour Envelope Curve......................................25

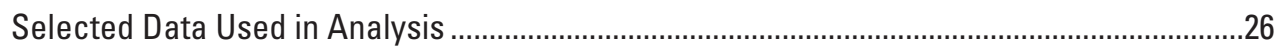

Variables Influencing Pier Scour ...........................................................................................28

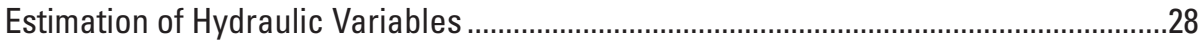

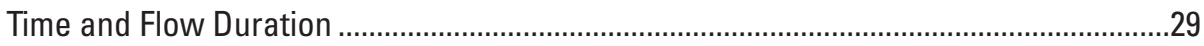

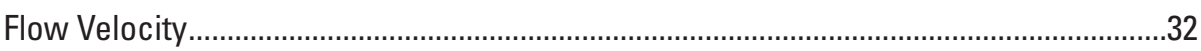

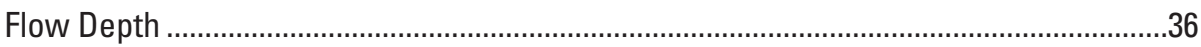

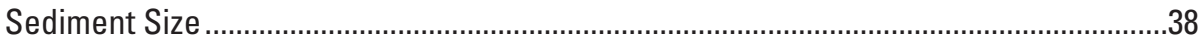

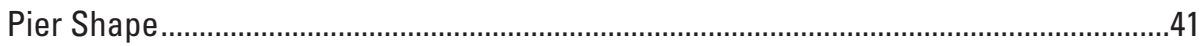

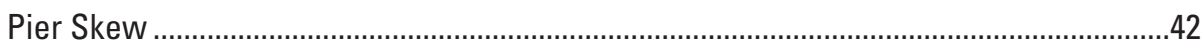

Pier Width and the South Carolina Live-Bed Pier-Scour Envelope Curve .............................43

Envelope Curves for Laboratory and Field Data .............................................................43

Equation for the South Carolina Pier-Scour Envelope Curve ...........................................48

Evaluation of Selected Methods for Predicting Live-Bed Pier Scour in South Carolina .................49

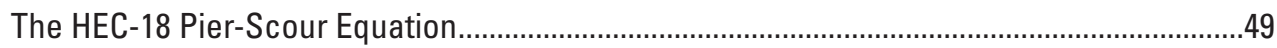

The South Carolina Modified Pier-Scour Equation ...................................................................51

The South Carolina Live-Bed Pier-Scour Envelope Curve .........................................................53

Guidance for Evaluating Live-Bed Pier-Scour Depth in South Carolina..........................................55

Evaluating Scour Depth at Pier Widths Less Than or Equal to 6 Feet ....................................55

Evaluating Scour Depth at Pier Widths Greater Than 6 Feet .................................................56

Evaluating Top Widths of Pier-Scour Holes..........................................................................5 
Development of the South Carolina Live-Bed Contraction-Scour Envelope Curves........................58

Live-Bed Contraction Scour in the Coastal Plain and Piedmont .............................................59

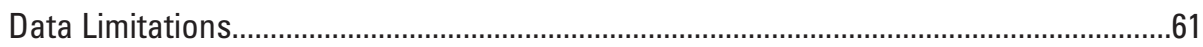

Other Sources of Field Data ..............................................................................................64

Comparison of Measured and Predicted Contraction-Scour Depths Using the

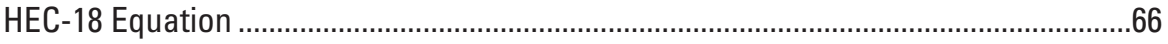

Dimensionless Envelope Curves for Live-Bed Contraction Scour .........................................68

Field Envelope Curve for Live-Bed Contraction Scour .........................................................82

Comparison of Methods for Assessing Live-Bed Contraction Scour ....................................87

Guidance and Limitations for Assessing Live-Bed Contraction Scour ..................................88

Channel Bends and Natural Constrictions of Flow ......................................................88

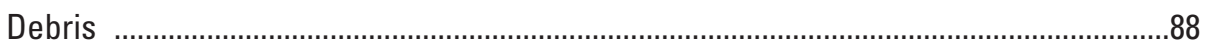

Elevation of Scour-Resistant Subsurface Soils .........................................................94

The Geometric-Contraction Ratio ……………………………………………….....97

The Quantitative Assessment of Live-Bed Contraction Scour.........................................97

Limitations of the Envelope Curves...............................................................................98

Selecting a Reference Surface for Live-Bed Contraction Scour .............................................98

Pier Scour Within and the Location of Live-Bed Contraction Scour .......................................98

The South Carolina Live-Bed Pier- and Contraction-Scour Database ..............................................99

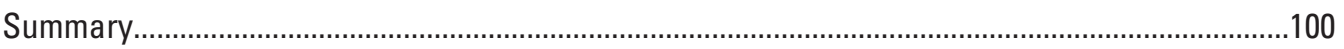

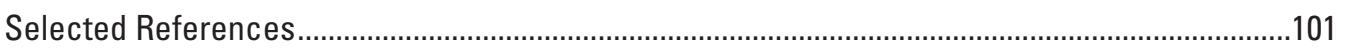

Appendix 1. Explanation of Variables in the South Carolina Live-Bed Pier-

and Contraction-Scour Database ..................................................................................103

Appendix 2. South Carolina bridge-scour study sites and reference numbers for figure 2 . 


\section{Figures}

1-2. Maps showing-

1. Locations of clear-water scour study sites from previous investigations of scour in South Carolina...

2. Locations of physiographic provinces and live-bed bridge-scour study sites in South Carolina

3-6. Graphs showing-

3. Distribution of streambed slopes for selected bridges in the Coastal Plain and Piedmont Physiographic Provinces of South Carolina.

4. Distribution of drainage areas for selected bridges in the Coastal Plain and Piedmont Physiographic Provinces of South Carolina.

5. Distribution of the ratio of the approach channel flow velocity to the critical velocity of the median grain size for selected bridges in the Coastal Plain and Piedmont Physiographic Provinces of South Carolina.

6. Distribution of bridge age at selected bridges in the Coastal Plain and Piedmont Physiographic Provinces of South Carolina, 2005.

7-9. Photographs showing-

7. Collection of subsurface channel and scour data at structure 454004100500 on S.C. Route 41, crossing Black Mingo Creek in Williamsburg County, South Carolina

8. Collection of subsurface channel and scour data at structure 427006200500 on Road S-62, crossing the South Tyger River in Spartanburg County, South Carolina.

9. Vibracore system used to collect subsurface sediments

10. Example of ground-penetrating radar longitudinal profile at structure 262050110100 on U.S. Route 501, crossing the Little Pee Dee River in Horry County, South Carolina.

11. Graph showing distribution of pile and pier widths for selected bridges in

the Coastal Plain and Piedmont Physiographic Provinces of South Carolina.

12. Sketch showing generalized profile of bridge pile bent

13-15. Photographs showing-

13. Timber pile bent at structure 337008500100 on Road S-85, crossing Hard Labor Creek in McCormick County, South Carolina

14. Steel H-pile bent at structure 237006800100 on Road S-68, crossing the Reedy River in Greenville County, South Carolina.

15. Square concrete pile bent at structure 174000900200 on S.C. Route 9 , crossing the Little Pee Dee River in Dillon County, South Carolina

16. Sketch showing generalized profile of pier on spread footing and pile group ...............22

17. Photograph showing pier supported on pile groups at structure 264002220100 on S.C. Route 22, crossing the Waccamaw River in Horry County, South Carolina..............22

18. Generalized profile of composite bent ..................................................................23

19. Photograph showing composite bent at structure 182001500100

on U.S. Route 15, crossing the Edisto River in Dorchester County, South Carolina 
20-21. Graphs showing-

20. Relation of measured live-bed pier-scour depth and pier width for selected sites in the Piedmont and Coastal Plain Physiographic Provinces of South Carolina ..

21. Relation of measured live-bed pier-scour depth and pier width for selected laboratory and field data

22. Illustration of scour at a cylindrical pier.

23. Illustration showing generalized relation of pier-scour depth to time 29

24-52. Graphs showing-

24. Simulated 100 -year-flow hydrographs for 200 -square-mile basins in the Piedmont and lower Coastal Plain Physiographic Provinces of South Carolina......29

25. Hydrograph durations at 95 percent of the peak flow estimated from simulated 100-year-flow hydrographs for various basin sizes in the Piedmont and lower Coastal Plain Physiographic Provinces of South Carolina ......30

26. Relation of measured live-bed pier-scour depth and the estimated peak-flow duration for historic peak flows at selected sites in the Coastal Plain and Piedmont Physiographic Provinces of South Carolina 31

27. Generalized relation of flow intensity and relative pier scour based on laboratory investigations.

28. Distribution of sediment gradation for selected bridges in the Coastal Plain and Piedmont Physiographic Provinces of South Carolina

29. Relation of measured live-bed pier-scour depth and approach-flow velocity for laboratory data.

30. Relation of measured live-bed pier-scour depth and the approach-flow velocity for historic peak flows at selected sites in the Coastal Plain Physiographic Province and Piedmont Physiographic Province of South Carolina

31. Relation of measured live-bed pier-scour depth and approach-flow depth for laboratory data

32. Relation of measured live-bed pier-scour depth and the approach-flow depth for historic peak flows at selected sites in the Coastal Plain and Piedmont Physiographic Provinces of South Carolina.

33. General relation of relative sediment size to relative pier scour based on laboratory investigations.

34. Relation of measured live-bed pier-scour depth and median sediment size for laboratory data

35. Relation of measured live-bed pier-scour depth and the median sediment size at selected sites in the Coastal Plain and Piedmont Physiographic Provinces of South Carolina

36. Relation of measured live-bed pier-scour depth and pier width grouped by pier shape for selected sites without pier skews in the Coastal Plain and Piedmont Physiographic Provinces of South Carolina.

37. Relation of measured live-bed pier-scour depth, with and without pier skews, and pier width for selected sites in the Coastal Plain and Piedmont Physiographic Provinces of South Carolina.

38. Relation of pier width to live-bed pier-scour depth and relative scour for selected laboratory data.

39. Relation of pier width to measured live-bed pier-scour depth, and relative scour for selected data from laboratory investigations and field data from selected sites in South Carolina. 
40. Relation of live-bed pier-scour depth and pier width for selected data from the National Bridge Scour Database and selected sites in South Carolina..

41. Relation of pier width to measured scour depth for selected sites with known maximum historic flows in South Carolina.

42. Relation of live-bed pier-scour depth and pier width for selected sites in the Coastal Plain and Piedmont Physiographic Provinces of South Carolina

43. Relation of measured live-bed pier-scour depth to predicted pier-scour depth neglecting the complex pier computation and using the complex pier computation for the maximum historic flows at selected sites in South Carolina

44. Relation of pier width to prediction error neglecting the complex pier computation and using the complex pier computation for live-bed pier-scour depth using the HEC-18 pier-scour equation for selected sites in the Coastal Plain and Piedmont Physiographic Provinces of South Carolina

45. Relation of relative scour to the dimensionless variable, $\left(b / y_{1}\right)^{3} \mathrm{Fr}^{2}$, for laboratory data used to develop the original HEC-18 pier-scour equation and data from selected sites in South Carolina

46. Relation of measured live-bed pier-scour depth to the predicted pier-scour depth for maximum historic flows at selected sites in South Carolina

47. Relation of measured to predicted live-bed pier-scour depth for selected sites in the Coastal Plain and Piedmont Physiographic Provinces of South Carolina

48. Relation of measured to predicted pier scour using the South Carolina live-bed pier-scour envelope-curve equation for all data in the National Bridge Scour Database

49. Relation of measured scour-hole top width to predicted scour-hole top width based on the HEC-18 equation for selected sites in the Coastal Plain and Piedmont Physiographic Provinces of South Carolina.

50. Relation of measured pier-scour depth to scour-hole top width minus the pier width for selected sites in the Coastal Plain and Piedmont Physiographic Provinces of South Carolina

51. Relation of pier width to scour-hole top width for selected sites in the Coastal Plain and Piedmont Physiographic Provinces of South Carolina

52. Relation of elevation difference between the bottom of live-bed contraction-scour hole and the scour-resistant subsurface layer to the most likely estimate of the measured live-bed contraction-scour depth, and the worst-case estimate of the measured live-bed contraction-scour depth at selected sites in South Carolina

53-54. Topographic contour maps showing-

53. Example of clear-water contraction scour created by a severe contraction at structure 211009511400 on Interstate 95, crossing the Pee Dee River floodplain in Florence County, South Carolina, August 19, 1996.

54. Example of clear-water contraction scour created by severe contraction at structure 212030100100 on U.S. Route 301, crossing Douglas Swamp in Florence County, South Carolina, July 31, 1996. 
55-76. Graphs showing-

55. Relation of measured live-bed contraction-scour depth and the geometric-contraction ratio for selected field data

56. Relation of measured to predicted live-bed contraction-scour depth for the most likely estimate of measured scour, and the worst-case estimate of measured scour at selected sites in South Carolina and selected data from the National Bridge Scour Database and Hayes (1996)

57. Relation of prediction error for live-bed contraction-scour depth to the ratio of contracted to approach channel flow $\left(Q_{2} / Q_{1}\right)$, and the ratio of approach to contracted channel width $\left(W_{1} / W_{2}\right)$, at selected sites in South Carolina and selected data from the National Bridge Scour Database and Hayes (1996)

58. Relation of measured to predicted live-bed contraction-scour depth at selected sites in South Carolina and selected data from the National Bridge Scour Database and Hayes (1996).

59. Relation of prediction error for live-bed contraction-scour depth to the ratio of contracted to approach channel flow $\left(Q_{2} / Q_{1}\right)$ and the ratio of approach to contracted channel width $\left(W_{1} / W_{2}\right)$ at selected sites in South Carolina and selected data from the National Bridge Scour Database and Hayes (1996)

60. Relation of normalized live-bed contraction-scour depth to the contracted flow ratio $\left(Q_{2} / Q_{1}\right)$, at selected sites in South Carolina and selected data from the National Bridge Scour Database compared with theoretical envelope curves generated with the Laursen (1960) equation for field data having width ratios less than or equal to 1 and field data having width ratios less than 1.5 and greater than 1 .

61. Relation of normalized live-bed contraction-scour depth to the contracted flow ratio $\left(Q_{2} / Q_{1}\right)$, at selected sites in South Carolina and selected data from the National Bridge Scour Database and Hayes (1996) compared with theoretical envelope curves generated with the Laursen (1960) equation ......74

62. Relation of measured live-bed contraction-scour depth and the approach channel flow depth for selected sites in the Coastal Plain and Piedmont Physiographic Provinces of South Carolina.

63. Relation of normalized live-bed contraction-scour depth to the contracted flow ratio $\left(Q_{2} / Q_{1}\right)$, at selected sites in South Carolina and selected data from the National Bridge Scour Database and Hayes (1996) with envelope curves for the Coastal Plain and Piedmont Physiographic Provinces of South Carolina

64. Relation of normalized live-bed contraction-scour depth to the geometric-contraction ratio at selected sites in South Carolina and selected data from the National Bridge Scour Database and Hayes (1996) compared with the theoretical envelope curve generated with the Laursen (1960) equation with the flow ratio set to 1 .

65. Relation of the channel flow ratio $\left(Q_{2} / Q_{1}\right)$ to the geometric-contraction ratio at selected sites in the Coastal Plain and Piedmont Physiographic Provinces of South Carolina......

66. Relation of measured contraction-scour depth and the approach channel flow depth for live-bed and clear-water contraction-scour data at selected sites in South Carolina. 
67. Relation of normalized live-bed contraction-scour depth to the geometric-contraction ratio at selected sites in South Carolina and selected data from the National Bridge Scour Database and Hayes (1996) with envelope curves for the Coastal Plain and

Piedmont Physiographic Provinces of South Carolina

68. Relation of measured to predicted live-bed contraction-scour depth at selected sites in South Carolina and selected data from the National Bridge Scour Database and Hayes (1996)

69. Relation of prediction error for live-bed contraction-scour depth to the ratio of contracted to approach channel flow $\left(Q_{2} / Q_{1}\right)$ and the ratio of approach to contracted channel width $\left(W_{1} / W_{2}\right)$ at selected sites in South Carolina and selected data from the National Bridge Scour Database and Hayes (1996).

70. Relation of prediction error for live-bed contraction-scour depth to the geometric-contraction ratio, and the approach flow depth, at selected sites in South Carolina and selected data from the National Bridge Scour Database and Hayes (1996)

71. Relation of the geometric-contraction ratio and measured live-bed contraction-scour depth with envelope curves for the most likely estimate of measured scour depth and the worst-case estimate of measured scour depth at selected sites in South Carolina and selected data from the National Bridge Scour Database and Hayes (1996)

72. Comparison of the live-bed contraction-scour envelope for the South Carolina data to selected clear-water contraction-scour data collected in South Carolina

73. Selected data associated with maximum historic flows compared with the South Carolina field envelope curve

74. Relation of measured to predicted live-bed contraction-scour depths at selected sites in South Carolina and selected data from the National Bridge Scour Database and Hayes (1996)

75. Relation of prediction error for live-bed contraction-scour depth to the geometric-contraction ratio, and the approach-flow depth at selected sites in South Carolina and selected data from the National Bridge Scour Database and Hayes (1996).

76. Box plots for the prediction error associated with the HEC-18 modified Laursen (1960) equation, the dimensionless envelope curves in figure 67, and the South Carolina field envelope curve in figure $71 A$, when applied to field measurements from selected sites in South Carolina and selected data from the National Bridge Scour Database and Hayes (1996). . .87

77. Aerial photograph showing examples of channel bends that can increase scour potential at structure 262050110100 on U.S. Route 501 crossing the Little Pee Dee River in Horry County, South Carolina, and structure 092060100300 on U.S. Route 601 crossing the Congaree River in Calhoun County, South Carolina ......89 
78-81. Photographs showing-

78. Examples of debris accumulation that can increase scour potential at structure 307011200100 on Road S-112 crossing the Enoree River in Laurens County, South Carolina, and structure 307026300100 on Road S-263 crossing the Enoree River in Laurens County, South Carolina.

79. Examples of debris accumulation that can increase scour potential at structure 367004500100 on Road S-45 crossing the Enoree River in Newberry County, South Carolina, and structure 342007620100 on U.S. Route 76 crossing the Great Pee Dee River in Marion County, South Carolina.

80. Example of debris accumulation that can increase scour potential at structure 427095600100 on Road S-956 crossing the North Pacolet River in Spartanburg County, South Carolina.

81. Failure of structure 304041800300 on S.C. Route 418 crossing the Enoree River in Laurens County, South Carolina, during the August 1995 flood, and after the flood

82. Example of ground-penetrating radar longitudinal profile showing scour created by debris accumulation at structure 367004500100 on Road S-45 crossing the Enoree River in Newberry County, South Carolina.

83-86. Graphs showing-

83. Scour from the August 1995 flood likely created by debris accumulation at structure 307011200100 on Road S-112 crossing the Enoree River in Laurens County, South Carolina.

84. Scour from the August 1995 flood likely created by debris accumulation at structure 307026300100 on Road S-263 crossing the Enoree River in Laurens County, South Carolina.

85. Scour from the September 1945 flood likely created by debris accumulation and coffer dam at structure 342007620100 on U.S. Route 76 crossing the Great Pee Dee River in Marion County, South Carolina.

86. Relation of elevation differences between the bottom of live-bed contraction scour holes and the scour-resistant subsurface layer to the geometric-contraction ratio at selected sites in South Carolina. 


\section{Tables}

1. Estimate of maximum historic flows at selected bridge crossings in South Carolina ....10

2. Pier-skew correction coefficients for pile bents..............................................................42

3. Range of selected characteristics for 42 measurements of live-bed pier scour collected at 30 bridges in the Piedmont Physiographic Province of South Carolina

4. Range of selected characteristics for 99 measurements of live-bed pier scour collected at 45 bridges in the Coastal Plain Physiographic Province of South Carolina..

5. Range of selected characteristics for 54 measurements of live-bed contraction scour collected at 54 bridges in the Coastal Plain Physiographic Province of South Carolina.

6. Range of selected characteristics for 35 measurements of live-bed contraction scour collected at 35 bridges in the Piedmont Physiographic Province of South Carolina

7. Range of selected characteristics for 12 measurements of live-bed contraction scour collected at 8 bridges in the National Bridge Scour Database and from Hayes (1996)

8. Range of selected characteristics for 42 measurements of clear-water contraction scour created by severe contractions collected at 40 bridges in the Coastal Plain Physiographic Province and 2 bridges in the Piedmont Physiographic Province of South Carolina. 


\section{Conversion Factors, Datums, Abbreviations, and Acronyms}

\begin{tabular}{lcl}
\hline \multicolumn{1}{c}{ Multiply } & By & \multicolumn{1}{c}{ To obtain } \\
\hline inch (in.) & Length & \\
foot (ft) & 25.4 & millimeter $(\mathrm{mm})$ \\
mile $(\mathrm{mi})$ & 0.3048 & meter $(\mathrm{m})$ \\
& 1.609 & kilometer $(\mathrm{km})$ \\
\hline square mile $\left(\mathrm{mi}^{2}\right)$ & Area & \\
\hline & 2.590 & square $\mathrm{kilometer}\left(\mathrm{km}^{2}\right)$ \\
\hline cubic foot $\left(\mathrm{ft}^{3}\right)$ & Volume & \\
\hline & 0.02832 & cubic meter $\left(\mathrm{m}^{3}\right)$ \\
\hline foot per foot $(\mathrm{ft} / \mathrm{ft})$ & Flow Rate & \\
foot squared per second $\left(\mathrm{ft}^{2} / \mathrm{s}\right)$ & 0.02832 & meter per $\mathrm{meter}\left(\mathrm{m} / \mathrm{m}^{3}\right)$ \\
cubic foot per second $\left(\mathrm{ft}^{3} / \mathrm{s}\right)$ & 0.02832 & meter squared $\mathrm{per} \mathrm{second}\left(\mathrm{m}^{2} / \mathrm{s}\right)$ \\
foot per second $(\mathrm{ft} / \mathrm{s})$ & 0.02832 & cubic meter $\mathrm{per} \mathrm{second}\left(\mathrm{m}^{3} / \mathrm{s}\right)$ \\
\hline
\end{tabular}

Horizontal coordinate information is referenced to North American Datum of 1983 (NAD 83).

Vertical coordinate information is referenced to North American Vertical Datum of 1988 (NAVD 88).

Elevation, as used in this report, refers to distance above a vertical datum.

$\begin{array}{ll}\text { GPR } & \text { Ground-penetrating radar } \\ \text { FHWA } & \text { Federal Highway Administration } \\ \text { HEC-18 } & \text { Hydraulic Engineering Circular 18 } \\ \text { NBSD } & \text { National Bridge Scour Database } \\ \text { SCLBSD } & \text { South Carolina Live-Bed Scour Database } \\ \text { SCDOT } & \text { South Carolina Department of Transportation } \\ \text { USGS } & \text { U.S. Geological Survey } \\ \text { WSPRO } & \text { Water-Surface PROfile model } \\ \text { KHz } & \text { Kilohertz } \\ < & \text { Less than } \\ \leq & \text { Less than or equal to } \\ > & \text { Greater than } \\ \geq & \text { Greater than or equal to }\end{array}$




\title{
Development and Evaluation of Live-Bed Pier- and Contraction-Scour Envelope Curves in the Coastal Plain and Piedmont Provinces of South Carolina
}

\author{
By Stephen T. Benedict and Andral W. Caldwell
}

\section{Abstract}

The U.S. Geological Survey, in cooperation with the South Carolina Department of Transportation, used groundpenetrating radar to collect measurements of live-bed pier scour and contraction scour at 78 bridges in the Piedmont and Coastal Plain Physiographic Provinces of South Carolina. The 151 measurements of live-bed pier-scour depth ranged from 1.7 to 16.9 feet, and the 89 measurements of live-bed contraction-scour depth ranged from 0 to 17.1 feet. Using hydraulic data estimated with a one-dimensional flow model, predicted live-bed scour depths were computed with scour equations from the Hydraulic Engineering Circular 18 and compared with measured scour. This comparison indicated that predicted pier-scour depths generally exceeded the measured pier-scour depths, and at times predicted pier-scour depths were excessive (overpredictions were as large as 23.1 feet). For live-bed contraction-scour depths, predicted scour was sometimes excessive (overpredictions were as large as 14.3 feet), but often observed contraction scour was underpredicted.

For live-bed pier scour, trends in laboratory and field data were compared and found to be similar. The strongest explanatory variable was pier width, and an envelope curve for assessing the upper bound of live-bed pier scour was developed using pier width as the primary explanatory variable. Relations in the live-bed contraction-scour data also were investigated, and several envelope curves were developed using the geometric-contraction ratio as the primary explanatory variable. The envelope curves developed with the field data have limitations, but the envelope curves can be used as supplementary tools for assessing the potential for live-bed pier and contraction scour in South Carolina.

Data from this study were compiled into a database that includes photographs, measured scour depths, predicted scour depths, limited basin characteristics, limited soil data, and modeled hydraulic data. The South Carolina database can be used in the comparison of sites with similar characteristics to evaluate the potential for scour. In addition, the database can be used to evaluate the performance of various analytical methods for predicting live-bed pier and contraction scour.

\section{Introduction}

The U.S. Geological Survey (USGS), in cooperation with the South Carolina Department of Transportation (SCDOT), investigated clear-water abutment, contraction, and pier scour at 168 bridges (fig. 1) in the Piedmont and Coastal Plain Physiographic Provinces of South Carolina (Benedict, 2003; Benedict and Caldwell, 2006). These regions in South Carolina will hereafter in the report be referred to as the Piedmont and Coastal Plain. In South Carolina, clear-water scour primarily occurs on the floodplain; therefore, these investigations focused on the collection of data on the bridge overbanks and not in the main channel. The general objectives of these previous studies were to (1) collect historic field measurements of scour at sites that could be associated with major floods, (2) use the field data to assess the performance of the scourprediction equations listed in the Federal Highway Administration Hydraulic Engineering Circular No. 18 (HEC-18; Richardson and Davis, 2001), and (3) develop regional envelope curves as supplementary tools to help evaluate predicted scour in South Carolina.

The analyses from these investigations showed that the HEC-18 clear-water scour-prediction equations, in general, overpredicted scour depths and were often excessive. On occasion, significant underprediction occurred, indicating that the equations could not be relied upon to consistently give reasonable estimates of scour. Although the HEC-18 equations provide a valuable resource for assessing scour, the trends in the analysis highlighted the need for engineering judgment to determine if predicted scour is reasonable. To assist engineers in developing and applying this judgment, the collected field data were organized into regional envelope curves that displayed the range and trend for the upper limit of scour for each component of clear-water scour. While the regional envelope curves have limitations (Benedict, 2003; Benedict and Caldwell, 2006), they can be used as a supplementary tool to evaluate predicted scour as well as the potential for scour in South Carolina.

Based on the success of the previous studies on clearwater scour, the USGS, in cooperation with the SCDOT, began a field investigation in 2004 to study live-bed contraction 


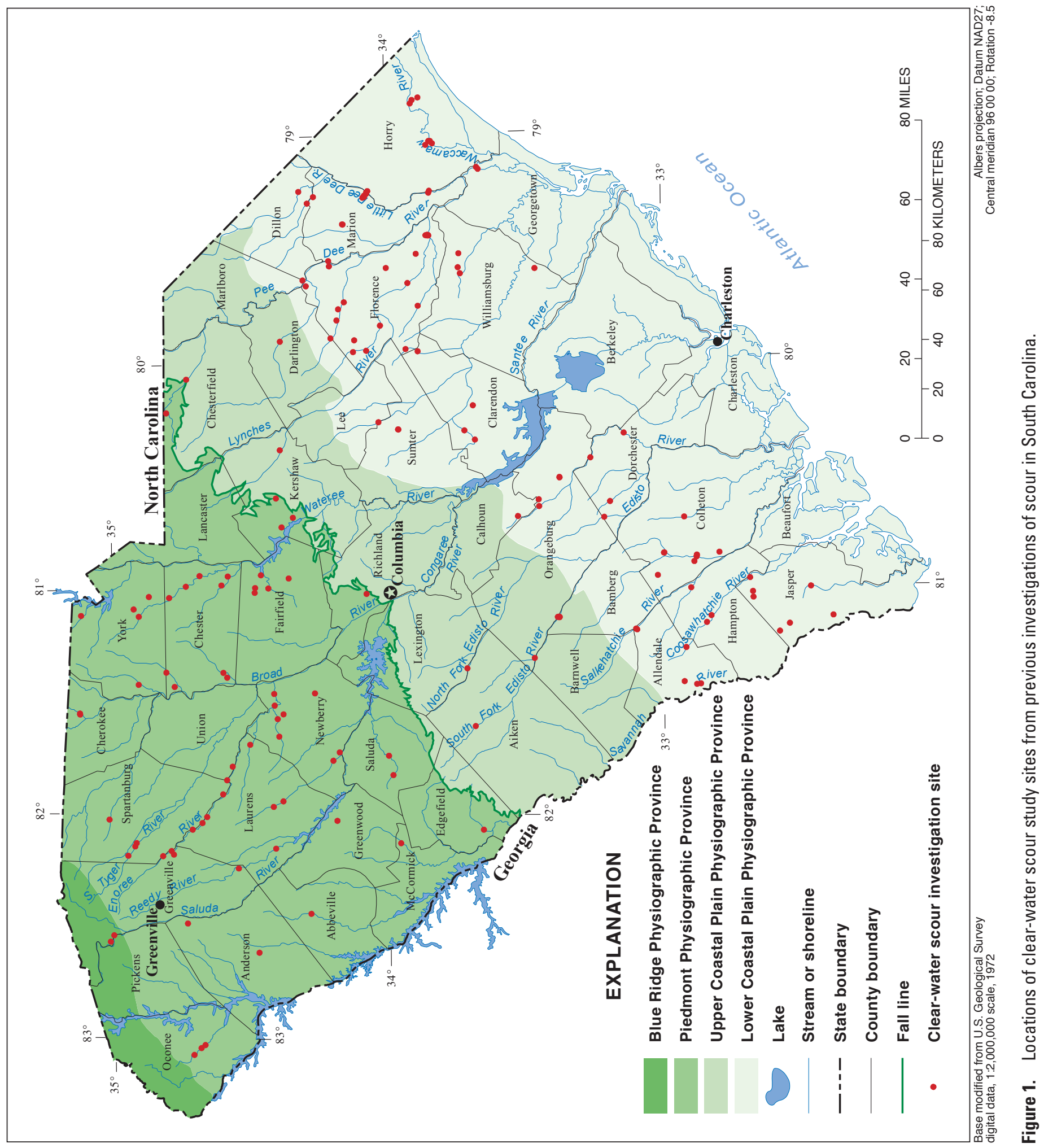


and pier scour. Because live-bed scour primarily occurs in the main channel of South Carolina streams, data collection focused on this part of the bridge opening of Piedmont and Coastal Plain bridges (fig. 2). The objectives of this investigation were to (1) collect field observations of live-bed contraction scour and pier scour at selected bridges in the Piedmont and Coastal Plain of South Carolina using ground-penetrating radar (GPR); (2) compare the observed scour with theoretical scour in order to evaluate the current scour-prediction methods in HEC-18 (Richardson and Davis, 2001); (3) investigate various physical relations that may help explain live-bed scour processes in South Carolina; and (4) if possible, develop regional envelope curves to help evaluate live-bed contraction and pier scour in South Carolina. If regional envelope curves for live-bed contraction and pier scour can be developed, then a full suite of envelope curves for the primary components of scour (clear water and live bed) will be available to help engineers evaluate predicted scour as well as the potential for scour in South Carolina.

Field data for bridge scour are limited; therefore, scour trends observed in the South Carolina data may help agencies in other States understand anticipated scour trends. The scour trends in South Carolina will likely be most applicable to States with similar regional characteristics. Agencies in States with differing regional characteristics may gain valuable insights regarding anticipated scour trends, and if desired, can use the approach in the South Carolina investigation to develop regional bridge-scour envelope curves for their own States.

\section{Purpose and Scope}

The purpose of this report is to describe (1) techniques used to collect live-bed contraction- and pier-scour data at 78 bridges in the Piedmont and Coastal Plain of South Carolina, (2) a comparison of predicted live-bed contraction- and pier-scour depths to measured scour depths, (3) selected relations in the field data, and (4) envelope curves that can be used to estimate ranges of anticipated live-bed contraction and pier scour at bridges in the Piedmont and Coastal Plain of South Carolina. In addition, a compilation of the data developed for each bridge is available for download at http://pubs.usgs.gov/ sir/2009/5099/. This compilation, which can be viewed using Microsoft Access ${ }^{\circledR}$, includes photographs, measured scour depths, predicted scour depths, limited basin characteristics, limited soil data, and modeled hydraulic data.

\section{Previous Investigations}

The USGS, in cooperation with the SCDOT, investigated scour in South Carolina in four previous studies. In the first investigation of level-1 bridge scour (1990-92), limited structural, hydraulic, geomorphic, and vegetative data were collected at 3,506 bridges and culverts in South Carolina, and observed- and potential-scour indexes were developed for each site (Hurley, 1996). These indexes, along with other variables, were used by the SCDOT to select sites in need of additional bridge-scour investigation.
In the second cooperative investigation of level-2 bridge scour (1992-95), detailed bridge-scour studies of 293 bridges in South Carolina were conducted using methods presented in HEC-18 (Richardson and others, 1991, 1993). Predicted scour depths determined in these studies were compared to bridgefoundation elevations to provide an indicator of the vulnerability of the bridges to failure. This information was used by the SCDOT to assist in determining if additional studies and (or) remedial actions were required to protect bridges from the threat of scour.

The level-1 and level-2 bridge-scour studies gave a qualitative overview of scour, which helped form general concepts of the type, magnitude, and frequency of scour throughout South Carolina. In addition, the level-2 bridge-scour studies provided evidence of the apparent discrepancy between the predicted and measured scour. This information was helpful in developing the approach for the third cooperative investigation, which was of clear-water contraction and abutment scour at selected bridges in the Piedmont and Coastal Plain. Clearwater abutment scour was investigated in the Piedmont and Coastal Plain, while the investigation of clear-water contraction scour was limited to the overbanks of Piedmont streams (Benedict, 2003). In the third investigation, field data were collected at 146 bridges, limited comparisons were made of predicted and measured scour depths, and field-data envelope curves were developed for evaluating clear-water abutment and contraction scour in South Carolina.

Based on the success of the initial field investigation of abutment and contraction scour, another cooperative investigation was initiated in October 2002 to investigate clear-water pier scour in the Piedmont and Coastal Plain and clear-water contraction scour in the Coastal Plain (Benedict and Caldwell, 2006). In this fourth investigation, field data were collected at 116 bridges, limited comparisons were made of predicted and measured scour depths, and field-data envelope curves were developed for evaluating clear-water pier and contraction scour in South Carolina. The assumptions and techniques used in these four previous investigations were used for the current investigation of live-bed contraction and pier scour.

\section{Description of Study Area}

South Carolina has an area of about 31,100 square miles $\left(\mathrm{mi}^{2}\right)$ and is divided into three physiographic provinces - the Blue Ridge, Piedmont, and Coastal Plain. The Coastal Plain is divided into upper and lower regions (fig. 2). The study area includes most of South Carolina but generally excludes the Blue Ridge and the tidally influenced area of the lower Coastal Plain. (Note: The Waccamaw River at S.C. Route 22 experienced a flood near the 100 -year flow magnitude in 1999. Although this site is tidally influenced at low flows, it functions similar to a non-tidal river at high flows and, therefore, was included in the investigation. This was the only site with any significant tidal influence that was included in the investigation.) 


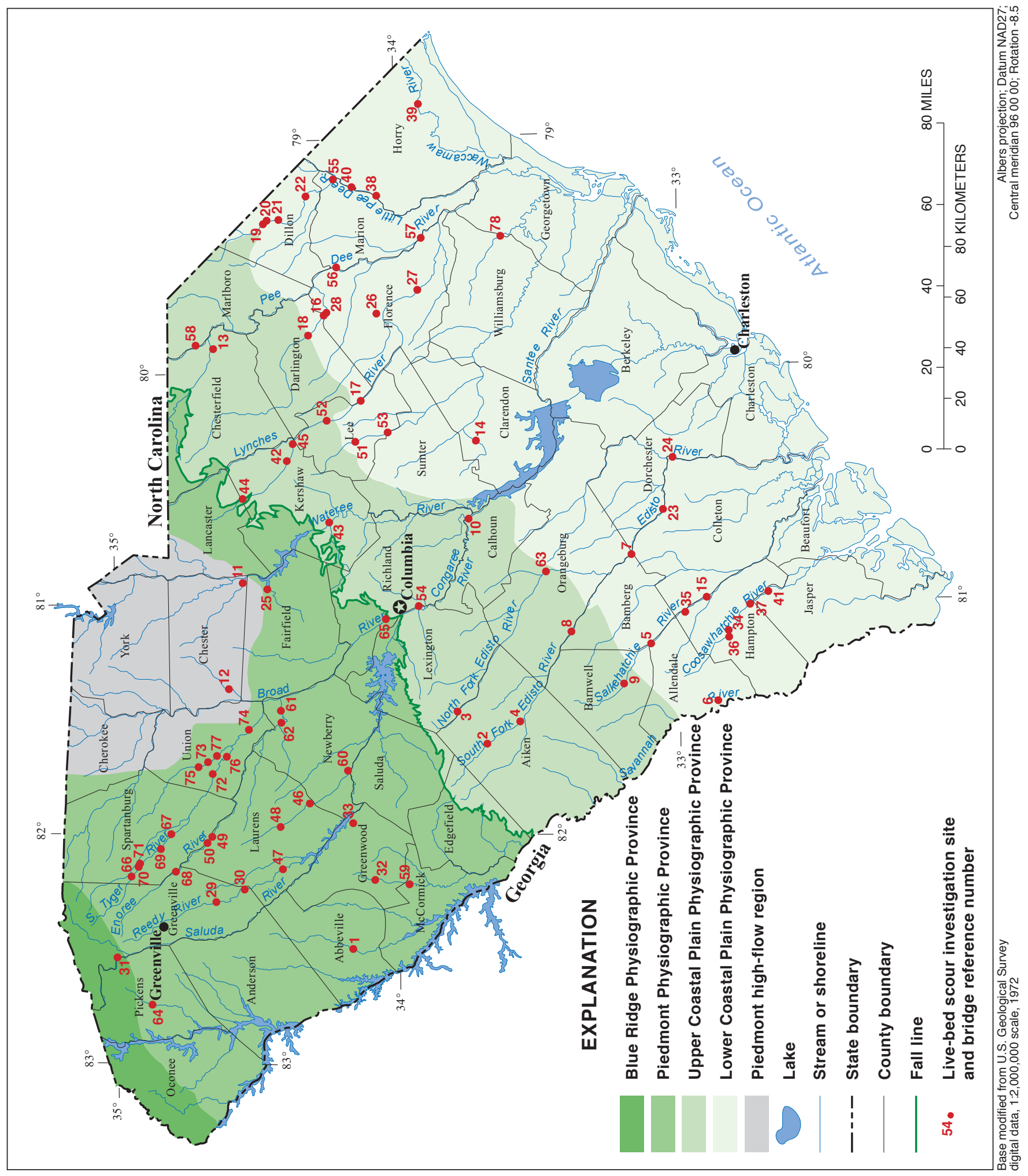

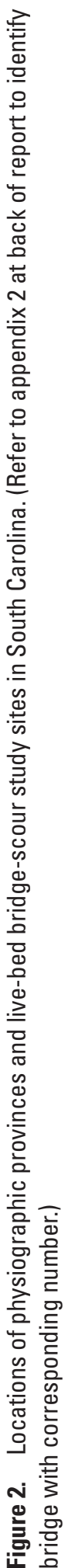


The Piedmont covers approximately 35 percent of South Carolina and lies between the Blue Ridge and Coastal Plain (fig. 2). Land-surface elevations range from about 400 feet (ft) near the Fall Line (Coastal Plain boundary) to about 1,000 ft at the Blue Ridge boundary. The general topography includes rolling hills, elongated ridges, and moderately deep to shallow valleys. The drainage patterns are well developed with welldefined channels and densely vegetated floodplains. Streambed slopes in the Piedmont range from approximately 0.00015 to 0.0100 foot per foot (ft/ft; Guimaraes and Bohman, 1992).

The geology of the Piedmont consists of fractured crystalline rock overlain by moderately to poorly permeable siltyclay loams. Alluvial deposits along the valley floors consist of clay, silt, and sand, and form varying degrees of cohesive soils (Guimaraes and Bohman, 1992). The channel sediments typically consist of sand overlaying decomposed rock or bedrock.

In this investigation, 32 bridges in the Piedmont were surveyed for live-bed contraction and pier scour. Limited data indicate that peak flows are higher in the northeastern region of the Piedmont than in the western region (Guimaraes and Bohman, 1992; Feaster and Tasker, 2002). This area is designated as the Piedmont high-flow region (fig. 2), and 3 of the 32 Piedmont sites are located in this region. (One site is located just outside of the high-flow region. Flows at the site are thought to be similar to or influenced by the high-flow region; therefore, this site was considered to be within the Piedmont high-flow region.) Streambed slopes and drainage areas for the 32 sites range from 0.00015 to $0.00210 \mathrm{ft} / \mathrm{ft}$ (fig. 3) and 21 to $5,250 \mathrm{mi}^{2}$ (fig. 4), respectively.

The upper Coastal Plain is bounded by the Piedmont and lower Coastal Plain, and covers approximately 20 percent of the State (fig. 2). The general topography in the upper Coastal Plain consists of rounded hills with gradual slopes, and land-surface elevations that range from less than $200 \mathrm{ft}$ to more than $700 \mathrm{ft}$. The geology consists primarily of sedimentary rocks composed of layers of sand, silt, clay, and gravel underlain by igneous rocks (Zalants, 1990). A shallow surface layer of permeable sandy soils is common. Low-flow channels bounded by densely vegetated floodplains characterize upper Coastal Plain streams, and the channel sediments typically consist of sand overlaying rock. Streambed slopes are moderate, ranging from approximately 0.0005 to $0.0040 \mathrm{ft} / \mathrm{ft}$ (Guimaraes and Bohman, 1992). In this investigation, 16 bridges in the upper Coastal Plain were surveyed for live-bed contraction and pier scour.

The lower Coastal Plain covers about 43 percent of the State (fig. 2). The topographic relief in the lower Coastal Plain is less pronounced than that of the upper Coastal Plain, and

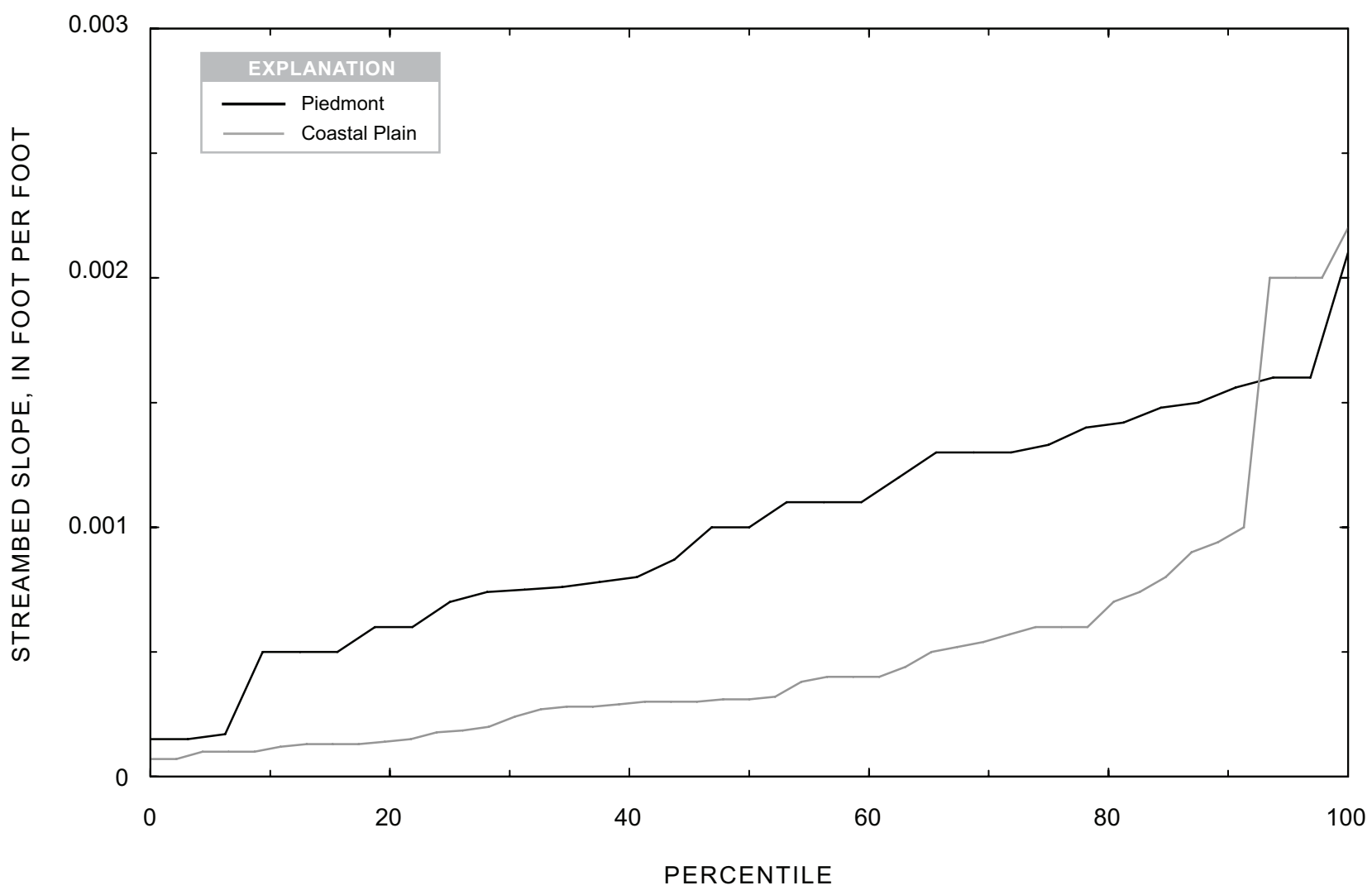

Figure 3. Distribution of streambed slopes for selected bridges in the Coastal Plain and Piedmont Physiographic Provinces of South Carolina. 


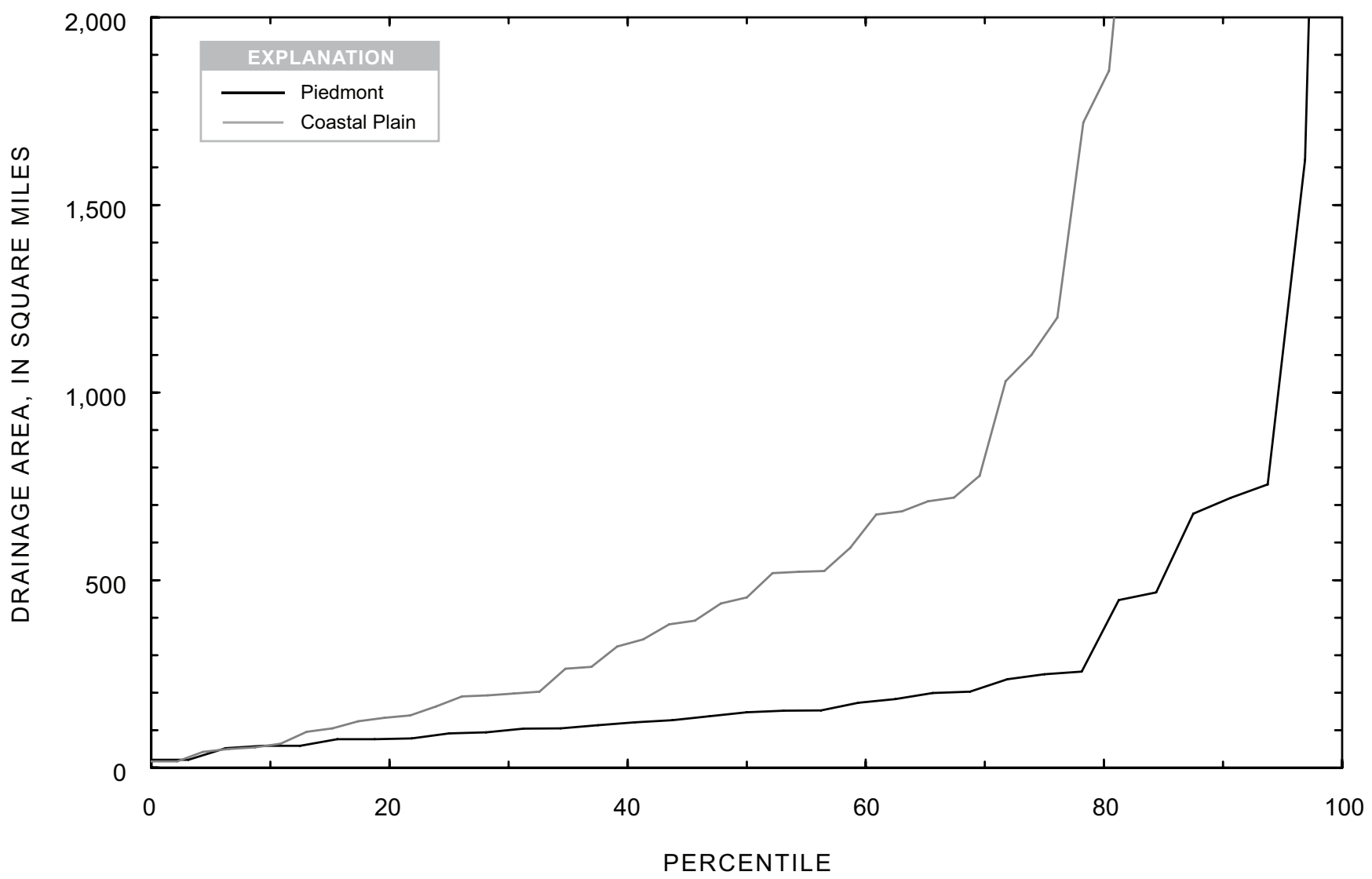

Figure 4. Distribution of drainage areas for selected bridges in the Coastal Plain and Piedmont Physiographic Provinces of South Carolina. (Note: Vertical scale has been truncated for graph clarity at small drainage areas.)

land-surface elevations range from $0 \mathrm{ft}$ at the coast to nearly $200 \mathrm{ft}$ at the boundary with the upper Coastal Plain. The geology of the lower Coastal Plain consists of loosely consolidated sedimentary rocks of sand, silt, clay, and gravel overlain by permeable sandy soils (Zalants, 1991). As in the upper Coastal Plain, the low-flow channels bounded by densely vegetated floodplains characterize the lower Coastal Plain streams, and the channel sediments typically consist of sand overlaying sedimentary rock. Streambed slopes range from approximately 0.0001 to $0.0040 \mathrm{ft} / \mathrm{ft}$, and streamflow patterns are tidally influenced near the coast (Guimaraes and Bohman, 1992). In this investigation, 30 bridges in the lower Coastal Plain were surveyed for live-bed contraction and pier scour. Streambed slopes and drainage areas for the 46 sites in the upper and lower Coastal Plain range from 0.00007 to $0.00220 \mathrm{ft} / \mathrm{ft}$ (fig. 3) and 17 to 9,360 $\mathrm{mi}^{2}$ (fig. 4), respectively.

\section{Approach}

Laboratory investigations of bridge scour have frequently used envelope curves to display the trends of scour and to develop tools for evaluating the potential for scour (Breusers and others, 1977; Dongol, 1993; Melville and Coleman, 2000). With the current use of computers to model complex physical phenomena, the use of envelope curves for evaluating bridge scour seems too simplistic and somewhat archaic. However, the use of simple envelope curves, in large measure, stems from the limited understanding of the complex mechanisms that create scour. The following quotations from selected researchers highlight this fact. In the findings of an extensive literature review of pier scour, Breusers and others (1977) state:

"...as in many other fields of sediment transport, up to now no entirely satisfactory theoretical and experimental results have been obtained, because the process involved of water and sediment movement are too complicated and experimental data are incomplete and sometimes conflicting."

Melville and Coleman (2000), in their extensive summary of the state of the knowledge and practice of bridge scour, state:

"The theoretical basis for the structural design of bridges is well established. In contrast, the mechanisms of flow and erosion in mobile-boundary channels have not been well defined and it is not 
possible to estimate with confidence the river boundary changes that may occur at a bridge subject to a given flood. This is not only due to the extreme complexity of the problem, but also to the fact that river characteristics, bridge constriction geometry, and soil and water interaction are different for each bridge as well as for each flood."

The limited understanding of the "extreme complexity" associated with bridge scour has necessitated the use of envelope curves for defining scour trends in laboratory investigations and is a practice that likely will be associated with this discipline for years to come. Although envelope curves of laboratory data cannot provide a precise estimate of bridge scour, they are useful tools in helping the practitioner understand the upper-bound trends of scour for various conditions. Known problems, however, are associated with small-scale laboratory investigations of bridge scour, including oversimplification of site conditions within the laboratory and scaling issues, both of which may lead to unreasonable estimates of scour when scaled to the field (Ettema and others, 1998).

One approach to minimizing these problems is to use field data, rather than laboratory data, to define bridge-scour envelope curves. The use of field envelope curves may eliminate problems associated with small-scale laboratory investigations and provide the practitioner with a better understanding of scour trends within the field setting. This is the approach used in the current investigation to develop tools for evaluation of live-bed pier scour and contraction scour in South Carolina. Numerous field observations of live-bed pier and contraction scour data were collected in the Coastal Plain and Piedmont of South Carolina, and dominant explanatory variables were used to develop envelope curves to define the upper bound of scour. While the envelope curves have limitations, they are valuable supplementary tools for assessing the potential for live-bed pier and contraction scour in South Carolina.

\section{Data Collection}

The USGS has collected historic scour data from field investigations in South Carolina and developed regional envelope curves for clear-water abutment, contraction, and pier scour since 1996. These envelope curves can be used to help evaluate the potential for bridge scour in these regions of South Carolina. The current investigation focuses on the development of envelope curves for live-bed contraction and pier scour. When using field envelope curves to evaluate scour potential, it is important to understand the type of data used to develop the envelope curve and the limitations of those data. The following sections describe assumptions regarding live-bed scour conditions and large floods, criteria for site selection, and techniques for collecting and interpreting the field data.

\section{Live-Bed Scour Conditions}

In the previous investigations (Benedict, 2003; Benedict and Caldwell, 2006), data collection focused on clearwater bridge scour in contrast to live-bed scour. Clear-water scour occurs at a bridge when upstream approach flows do not transport bed sediments into the area of scour. Scour holes developed under these conditions do not refill, and a nonobscured record of the maximum scour depth is preserved at the bridge. This record can be readily measured during lowflow and post-flood investigations, and the measured scour represents the maximum clear-water scour that has occurred during the life of the bridge. In South Carolina, clear-water scour primarily occurs on the floodplain, and in the previous investigations, data collection was limited to the floodplain section of the bridge opening. In contrast, live-bed scour occurs at a bridge when the approaching flow velocity exceeds the critical velocity for eroding sediments of a given size; therefore, sediments are transported along the streambed and into the area of scour. Because sediments are being transported into the area of scour, scour holes partially or totally refill with sediments as flood flows recede, making it difficult to measure scour depths during low-flow and post-flood conditions. In South Carolina, live-bed scour primarily occurs in the main channel, and data collection for the current investigation (2009) focused on scour in the main channel of the bridge opening.

Because the scour data in this investigation were collected in the main channel, it is appropriate to assume that the data reflect live-bed scour conditions. This assumption can be substantiated by comparing the approach flow velocity in the main channel to the critical velocity of the channel sediments. For the 46 bridges in the Coastal Plain, the average unconstricted velocity in the approach channel for the 100-year flow ranged from approximately 1.2 to 8.6 feet per second (ft/s) with a mean value of $3.1 \mathrm{ft} / \mathrm{s}$. (The 100 -year flow is defined as a flow that might occur one time in a 100 -year period, rather than exactly once every 100 years [Feaster and Tasker, 2002]). The ratio of the approaching channel flow velocity to the critical velocity of the median grain size for the Coastal Plain bridges indicates that approximately 70 percent of the bridges, theoretically, should have live-bed scour conditions in the channel (fig. 5). (Critical velocity was estimated with the equation presented in HEC-18 [Richardson and Davis, 2001]. While some error may be associated with the HEC-18 equation in the prediction of critical velocity, it is a widely accepted equation used for assessing critical velocity.) A review of the 14 Coastal Plain sites that appear to be clearwater scour in nature suggests that 9 of the sites likely have live-bed scour conditions. Four of these sites have ratios of approaching channel flow velocity to critical velocity of 0.96 and greater, indicating that they likely have live-bed scour conditions at high flows. Additionally, five sites have welldefined sand channels indicating that they likely have live-bed scour conditions. 


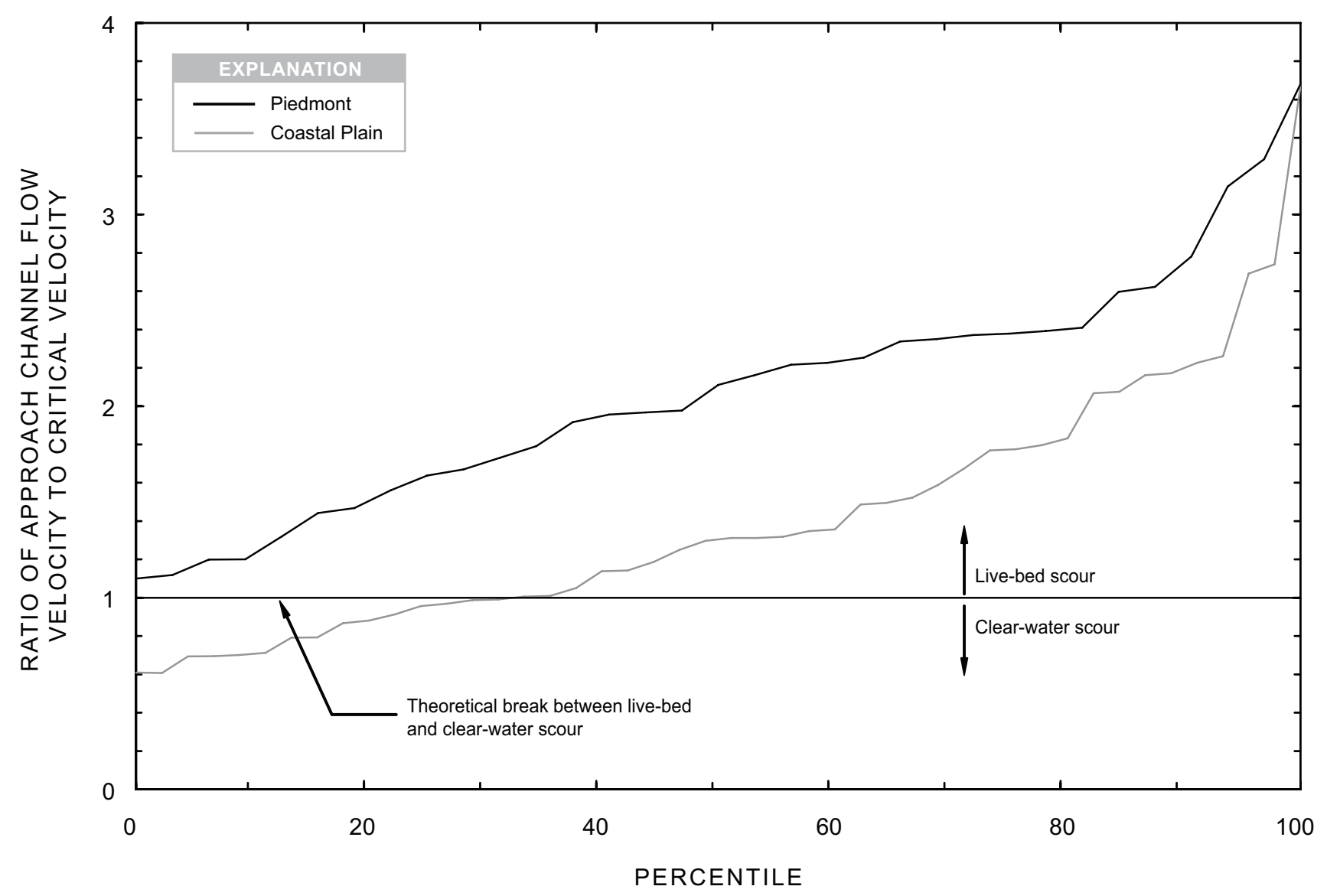

Figure 5. Distribution of the ratio of the approach channel flow velocity to the critical velocity of the median grain size for selected bridges in the Coastal Plain and Piedmont Physiographic Provinces of South Carolina.

For the 32 bridges in the Piedmont, the average unconstricted velocity in the approach channel for the 100-year flow ranged from approximately 2.4 to $9.3 \mathrm{ft} / \mathrm{s}$ with a mean value of $5.3 \mathrm{ft} / \mathrm{s}$. The percentile plot for the ratio of the approaching channel flow velocity to the critical velocity of the median grain size for the Piedmont bridges indicate that all of the bridges, theoretically, should have live-bed scour conditions in the channel (fig. 5).

The data in figure 5 indicate that live-bed scour conditions prevail in the channels of 64 bridges studied in the current investigation. Because of the uncertainty with hydraulic flow estimates (as well as reasons previously noted), the remaining 14 bridges also could be live-bed scour in nature. Therefore, while there is some uncertainty regarding prevailing scour conditions at these 14 sites, for purposes of this study, the data indicate that it is reasonable to assume that contraction- and pier-scour data collected in this investigation represent scour resulting from live-bed scour conditions.

\section{Assumption of Large Floods}

As demonstrated in the previous investigations (Benedict, 2003; Benedict and Caldwell, 2006), when sufficient scour data are collected at a large number of bridges, the data can be used to develop envelope curves for evaluating ranges of anticipated scour depths for given site conditions. For example, if collected data for live-bed pier-scour depths range from 0.0 to $7.8 \mathrm{ft}$ for a 4 -ft-wide pier in the sandy sediments of South Carolina channels, it would be reasonable to assume that an upper limit for scour depth at bridges with similar site conditions would be approximately $7.8 \mathrm{ft}$. When using observed scour data in such a manner, it must be assumed that the collected field data represent scour resulting from floods, such as those approaching the 100-year flood-flow magnitude. If the collected field data represent scour that has resulted only from minor floods, then the data cannot be used to evaluate scour resulting from large floods. However, if the measured data represent scour resulting from large floods, it is reasonable to use such data to evaluate the scour potential at other bridges with similar site characteristics.

The assumption that live-bed contraction- and pier-scour data collected in this investigation represent scour resulting from large flows is critical. The previous clear-water scour investigations (Benedict, 2003; Benedict and Caldwell, 2006) justified this assumption by demonstrating from risk analysis, streamgage records, and historic flood records that approximately 80 percent of the bridges from each investigation likely had flows equal to or exceeding 70 percent of the 100 -year 
flow. A similar approach is used in the current investigation to justify the assumption that measured scour is associated with large flows.

Benedict (2003) defines a large flow as any flow that equals or exceeds 70 percent of the 100 -year flow magnitude. Although this definition of a large flow is arbitrary, it was chosen, in part, because 70 percent of the 100-year rural flow, as determined by the South Carolina flood frequency regression equations (Feaster and Tasker, 2002), is approximately equal to the 25-year rural flow. If 70 percent of the 100 -year rural flow is assumed equal to the 25 -year rural flow, then a risk analysis can be made. The equation for risk (Bedient and Huber, 1988) is defined as follows:

$$
\text { Risk }=1-(1-1 / \mathrm{T})^{\mathrm{n}} \text {, }
$$

where

Risk is the probability that the T-year event will occur at least once in $\mathrm{n}$ years;

$\mathrm{T}$ is the recurrence interval, in years; and

$\mathrm{n}$ is the period for assessing risk, in years.

Using risk analysis, Benedict (2003) demonstrated that bridges 30 years or older have a high probability (71 percent) of having flows equaling or exceeding the 25 -year rural flow. In the current investigation, 72 of 78 bridges were 30 years or older in 2005 (fig. 6), indicating that large flows likely had occurred at these bridges. In addition, three of the six bridges less than 30 years old are known to have had flows exceeding the 25-year recurrence interval. The risk analysis, in conjunction with known maximum historic flows, indicates that large flows likely have occurred at approximately 96 percent of the bridges in this investigation, giving support to the assumption that a significant portion of the scour data collected in the investigation represents scour resulting from large flows.

The assumption of large flows can be further substantiated with streamgage data. A review of the streamgage records in South Carolina indicated that 61 of the bridges in this investigation were located at or near a streamgage or indirect measurement site having streamflow records partially or fully concurrent with the life of the bridge. (Note: Three of these bridges are indirect flow measurement sites.) Twenty-two of these bridge crossings were located at a streamgage or indirect measurement site, while 39 were located near a streamgage or indirect measurement site. Using the streamgage records, the maximum historic flows were estimated for these 61 bridge crossings (table 1). While the lack of full concurrence between

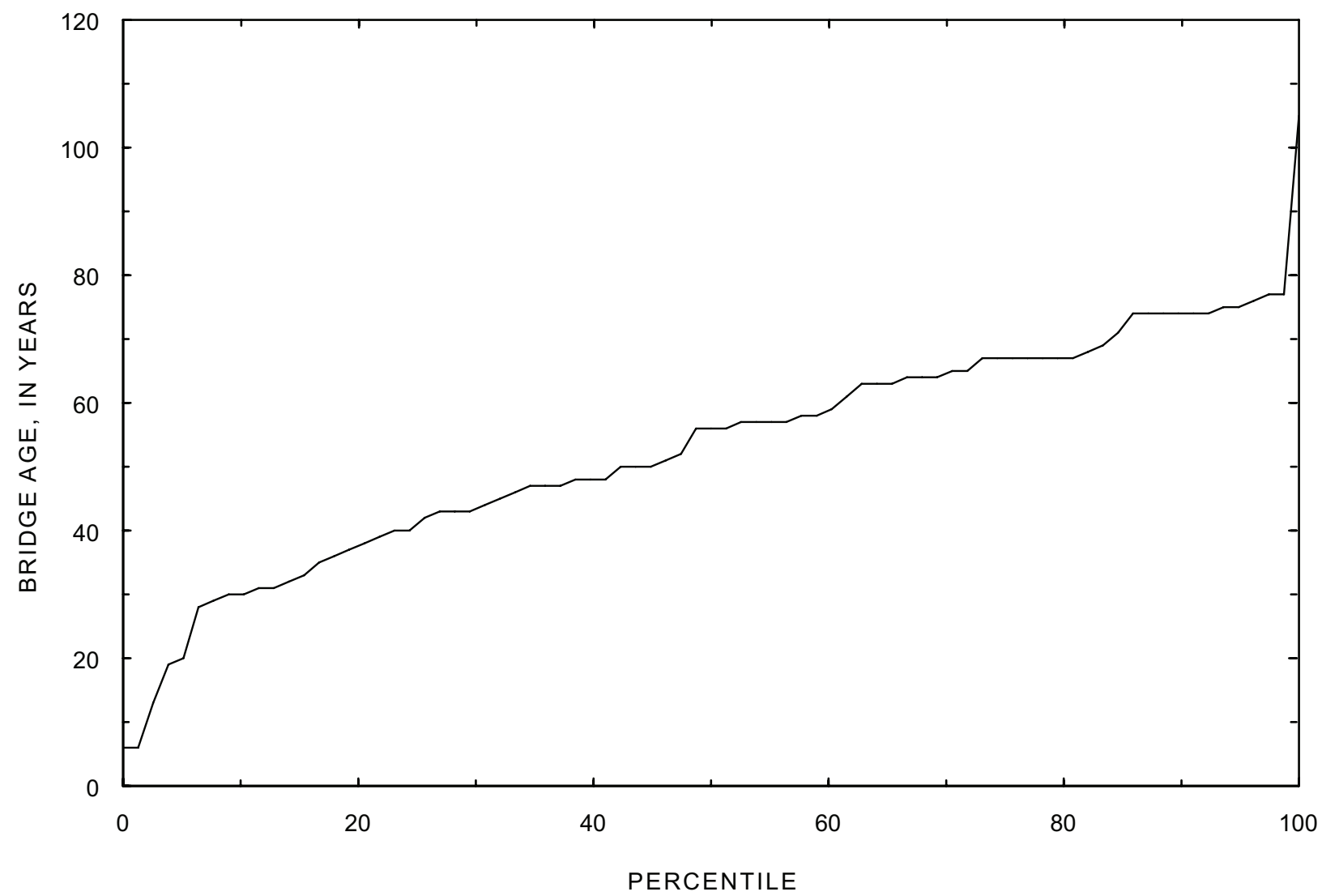

Figure 6. Distribution of bridge age at selected bridges in the Coastal Plain and Piedmont Physiographic Provinces of South Carolina, 2005. 


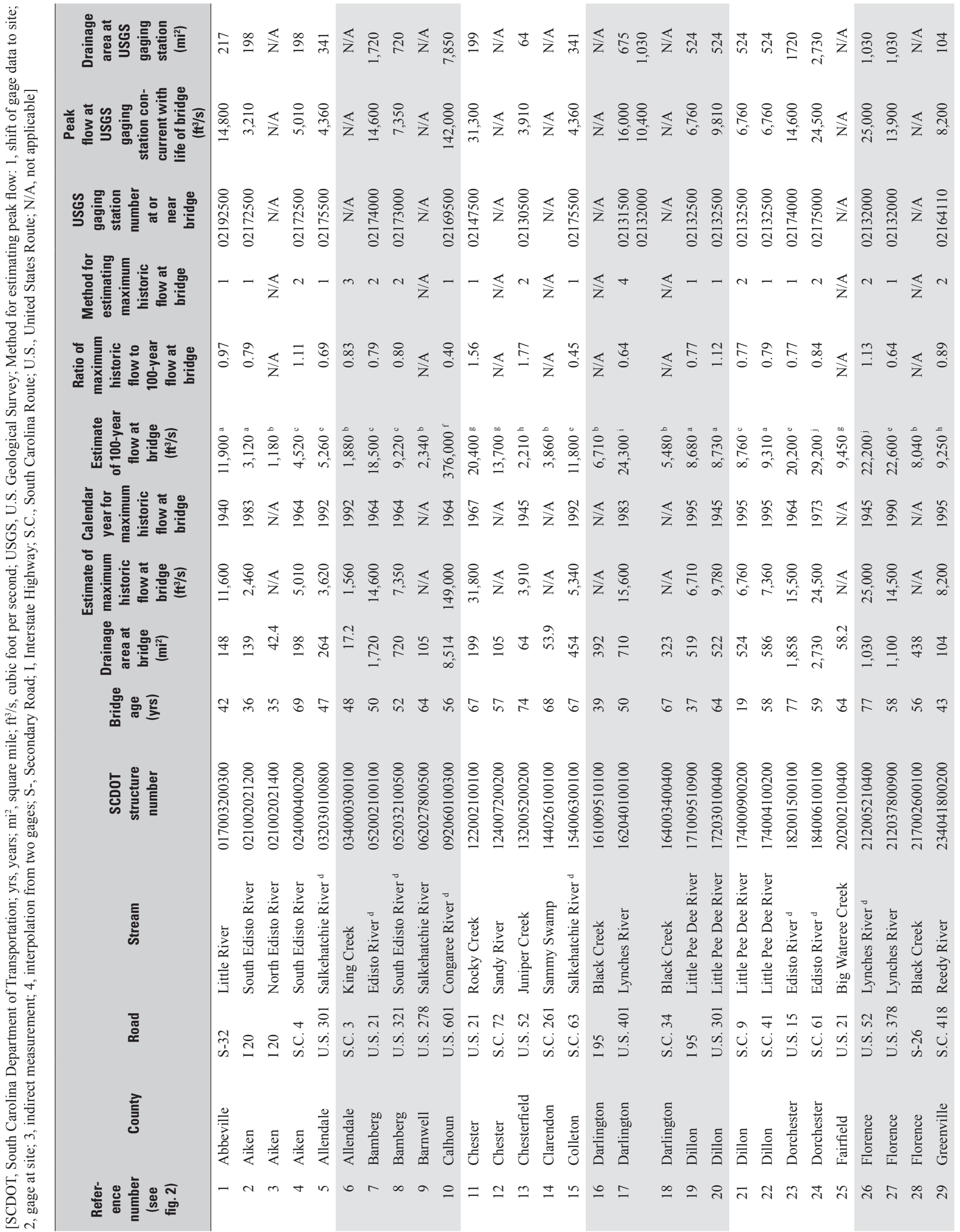




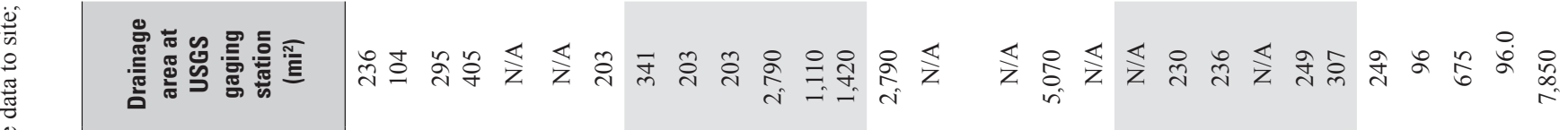

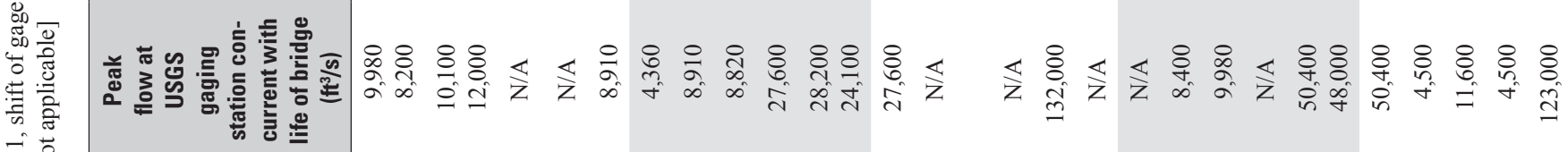
$\rightarrow \vec{\circ}$

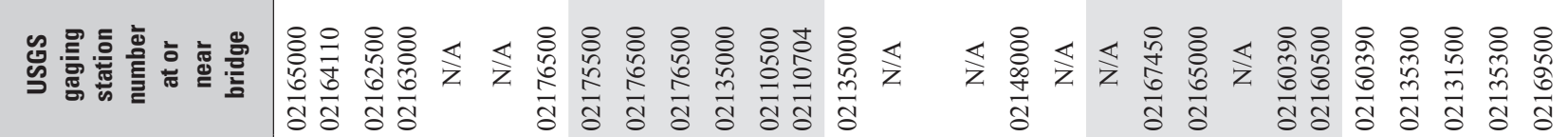

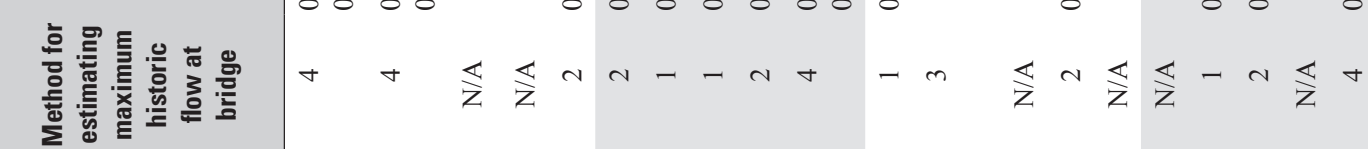

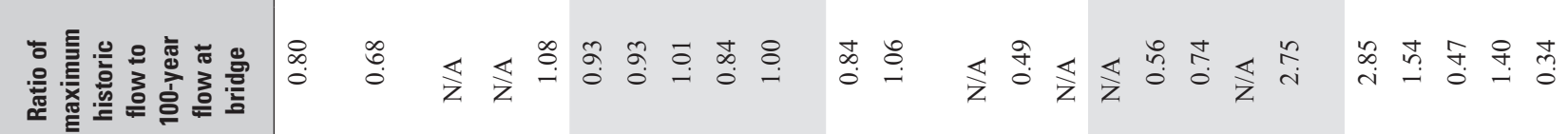

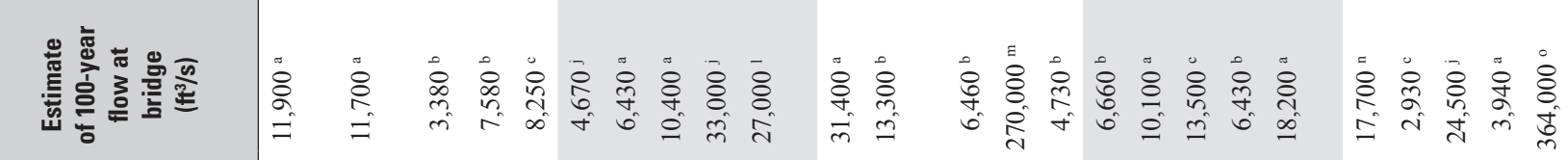

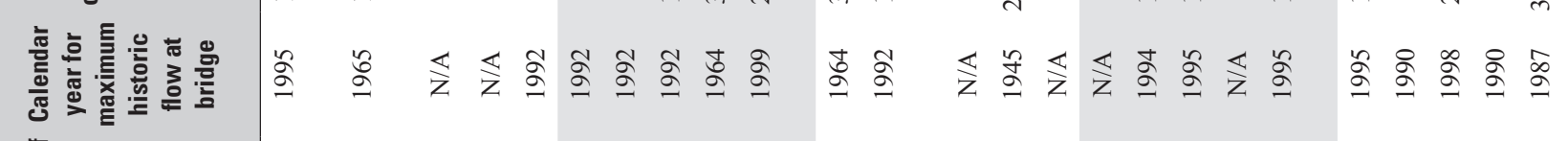

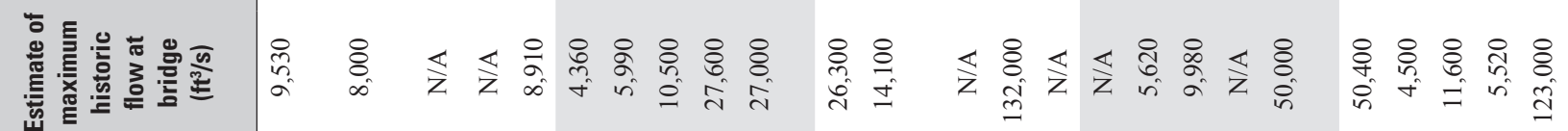

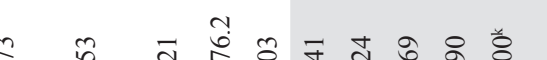




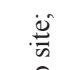

올

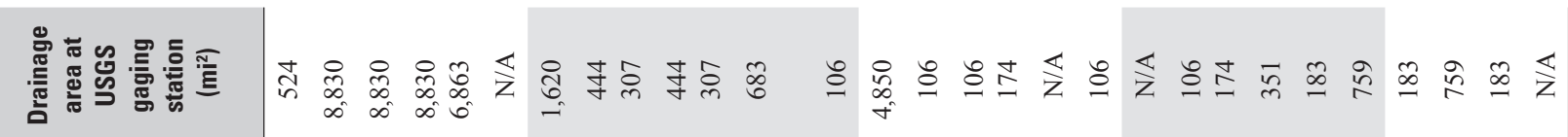

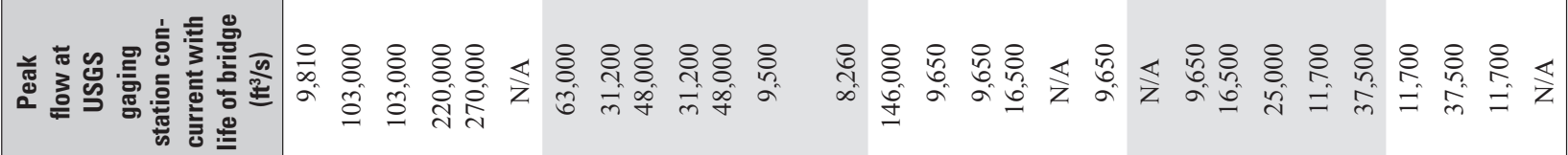

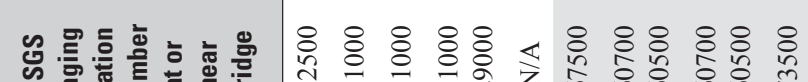

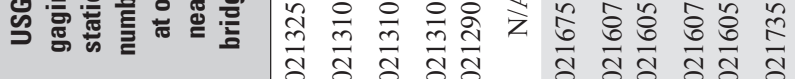

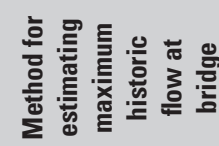

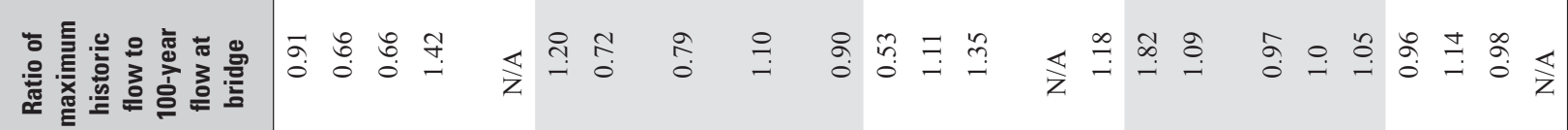

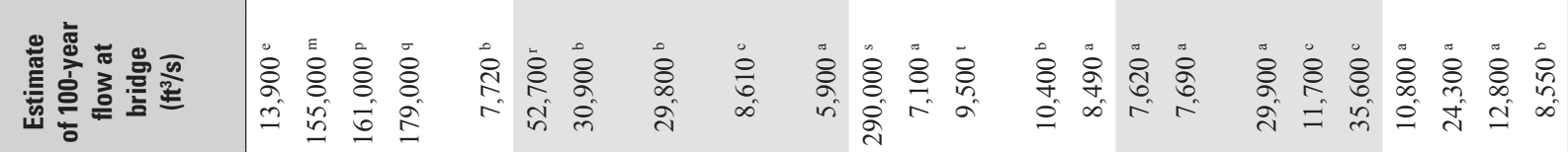

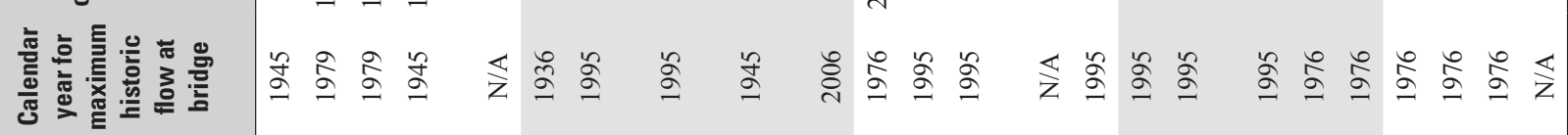

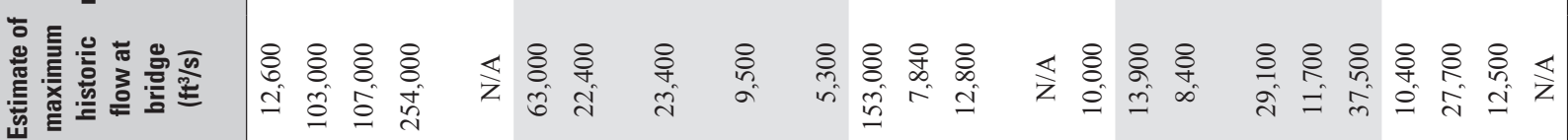

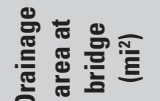
๑) 产喜旁

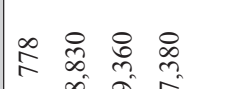

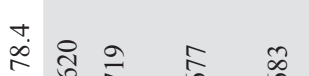

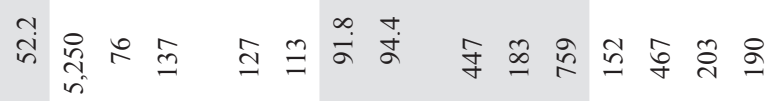
$\stackrel{b}{6}$ in

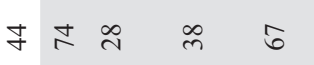
가의

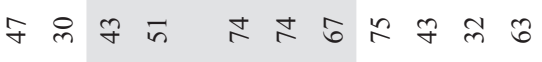

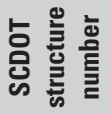

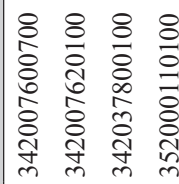

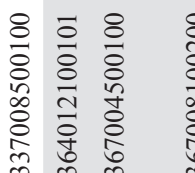

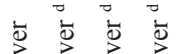

旅范

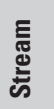

苋

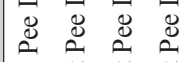

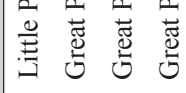

Uै

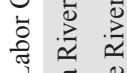

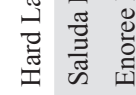

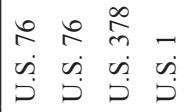

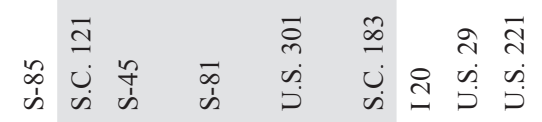

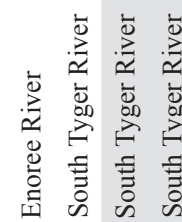

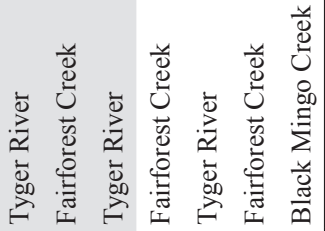

ฮั

守文

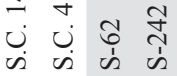

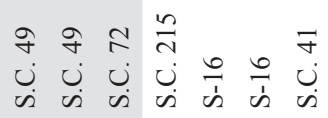

בั้

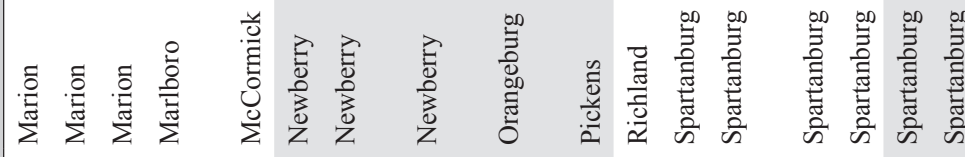

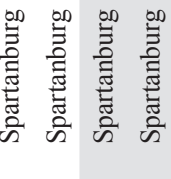

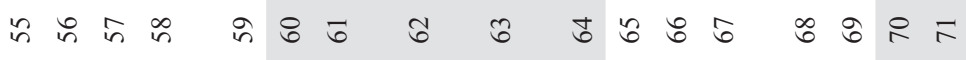

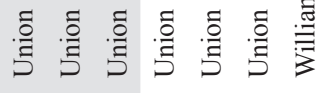




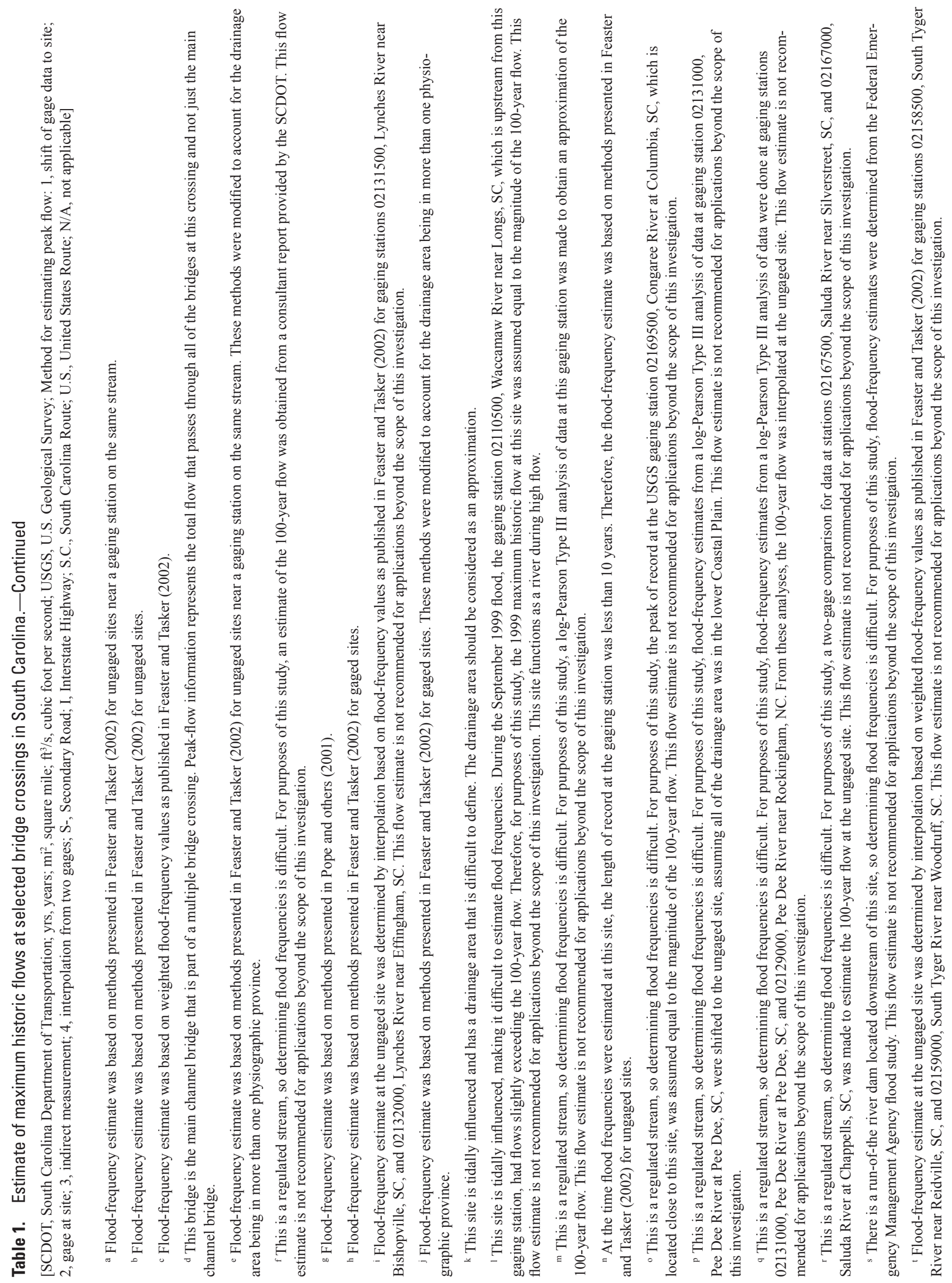


the bridge life and gage record at some sites limited the ability to determine the maximum historic flow over the full life of the bridge, the maximum historic flows based on the partially and fully concurrent gages provide valuable understanding of peak flows at the sites. Estimates of the maximum historic flows were obtained by (1) shifting streamgage data to the ungaged bridge site using methods presented in Feaster and Tasker (2002), (2) using streamgage data located at the bridge, (3) using indirect measurements of peak flows at the bridge from previous documentation of historic floods, and (4) interpolating streamgage data by drainage area when a bridge was located between or near two streamgages. The ratio of peak flow to the 100-year flow for the 61 bridge crossings ranges from 0.34 to 2.85 with a median ratio of 0.91 . Ratios are approximately 0.7 or greater for 48 of the 61 bridges, and an additional 8 bridges have ratios between 0.5 and 0.7 . These ratios indicate that the scour measurements at these bridges are good representations of scour resulting from large floods.

Streamgage records are not available for the remaining 17 bridges. These bridges have ages ranging from 35 to 74 years, indicating that they have a high probability of having experienced a large flood. Based on age and risk analysis at these 17 bridges, along with the streamgage records at the other 61 bridges, there is supporting evidence that floods at or near the 100-year flow have occurred at many, if not at most, of the sites in this investigation. This supports the assumption that the scour data collected in this investigation represent scour resulting from large floods. Therefore, the data likely will provide a good indicator for anticipated ranges of scour related to flows near the 100-year flow magnitude at bridges in South Carolina.

\section{Site Selection}

The collection of live-bed scour data at sites having experienced large flows was an important objective of this investigation. To identify sites that had experienced such flows, several sources of data were used. Initially, USGS streamgage records were reviewed to identify sites at or near streamflow gaging stations that had experienced large historic flows. Additionally, the SCDOT bridge inventory database was reviewed to identify older bridges that would have high probabilities for having withstood large historic floods. Using this list of potential sites, 78 bridges in South Carolina were selected for data collection: 32 bridges in the Piedmont and 46 bridges in the Coastal Plain. Sixty-one of these bridges were located at or near a streamflow gaging station, thus providing a means to assess the maximum historic flows at these sites. Ages of the 78 bridges ranged from 6 to 105 years (fig. 6), with a median age of 56. Seventy-two of the bridges are 30 years or older, indicating that they have a high probability of having experienced a large flood. In the selection process, an attempt was made to select bridge sites that would provide adequate representation of drainage-area size, bridge length, bridge contraction, and pier type. To minimize costs, sites with previously developed Water-Surface-PROfile models (Shearman, 1990) were used when possible. (For the remainder of the report, the Water Surface-PROfile model will be referred to as WSPRO or the WSPRO model.) A primary source of such sites was previous investigations in South Carolina. Eighteen of the bridges used in this investigation were from the level-2 bridge scour study (1992-95), and 22 of the bridges used in the previous clear-water scour investigations (Benedict, 2003; Benedict and Caldwell, 2006) also were used in the current investigation. Sixteen multiple-opening bridge crossings were used in this investigation; all were in the Coastal Plain, and field data were collected only at the main bridge and not at the overflow bridges. Additionally, there were 62 single-bridge crossings. Dual bridges, which are parallel bridges in close proximity to each other spanning the same stream, were considered to be one bridge rather than separate bridges.

\section{Techniques for the Collection and Interpretation of Field Data}

Techniques similar to those used in the aforementioned previous investigations were used to collect field data of live-bed contraction and pier scour. The basic field data collected at each site included (1) measurements of scour depths; (2) samples of bed material; and (3) photographs, sketches, and written descriptions of each site. Historic clear-water scour holes on the overbanks do not refill with sediments and, therefore, are highly visible and easily measured with conventional survey techniques. In contrast, live-bed scour holes in the main channel are inundated and have been partially or totally refilled with sediments, making field measurements of scour problematic because the results of scour are not visually apparent. Therefore, to measure historic live-bed scour, some type of subsurface investigation method, such as a geophysical technique, must be used. For this investigation, groundpenetrating radar (GPR) was used to estimate the depth of scour in the channel and around the piers.

\section{Collection of Field Data}

During this investigation, GPR data were collected using a RAMAC/X3M ${ }^{\mathrm{TM}}$ radar control unit and a 100-megahertz shielded antenna manufactured by MALA GeoScience. Data were viewed and stored on a laptop computer connected to the radar control unit. For access to points within a river channel, the GPR system was deployed by using variously sized inflatable boats. The antenna was placed in the bottom of the inflatable boat so that its radiating surface was as close to the air-water interface as possible. The inflatable boat provided a stable platform and had minimal effect on the radar signal transmission and reflection. In non-wadeable streams (depths greater than $3 \mathrm{ft}$ ), a 12-ft-long inflatable boat propelled by a motor was used to carry two crew members and the GPR system (fig. 7). In wadeable streams (depths $3 \mathrm{ft}$ or less), a small inflatable boat that carried only the GPR system was pushed or towed by hand (fig. 8). In the largest rivers, the small inflatable 


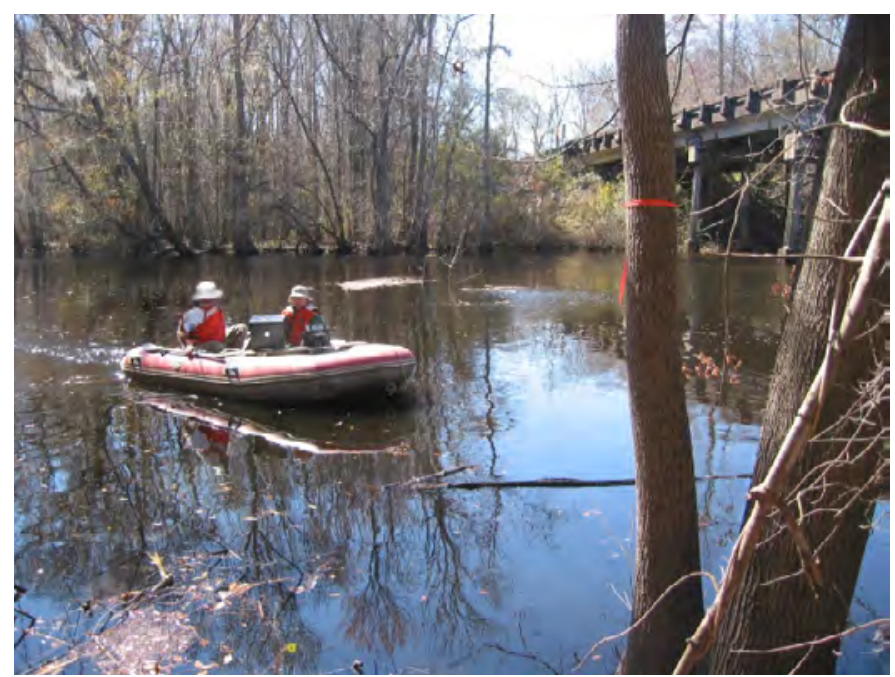

Figure 7. Collection of subsurface channel and scour data at structure 454004100500 on S.C. Route 41, crossing Black Mingo Creek in Williamsburg County, South Carolina. (Photograph by the U.S. Geological Survey, South Carolina Water Science Center, February 28, 2007.)

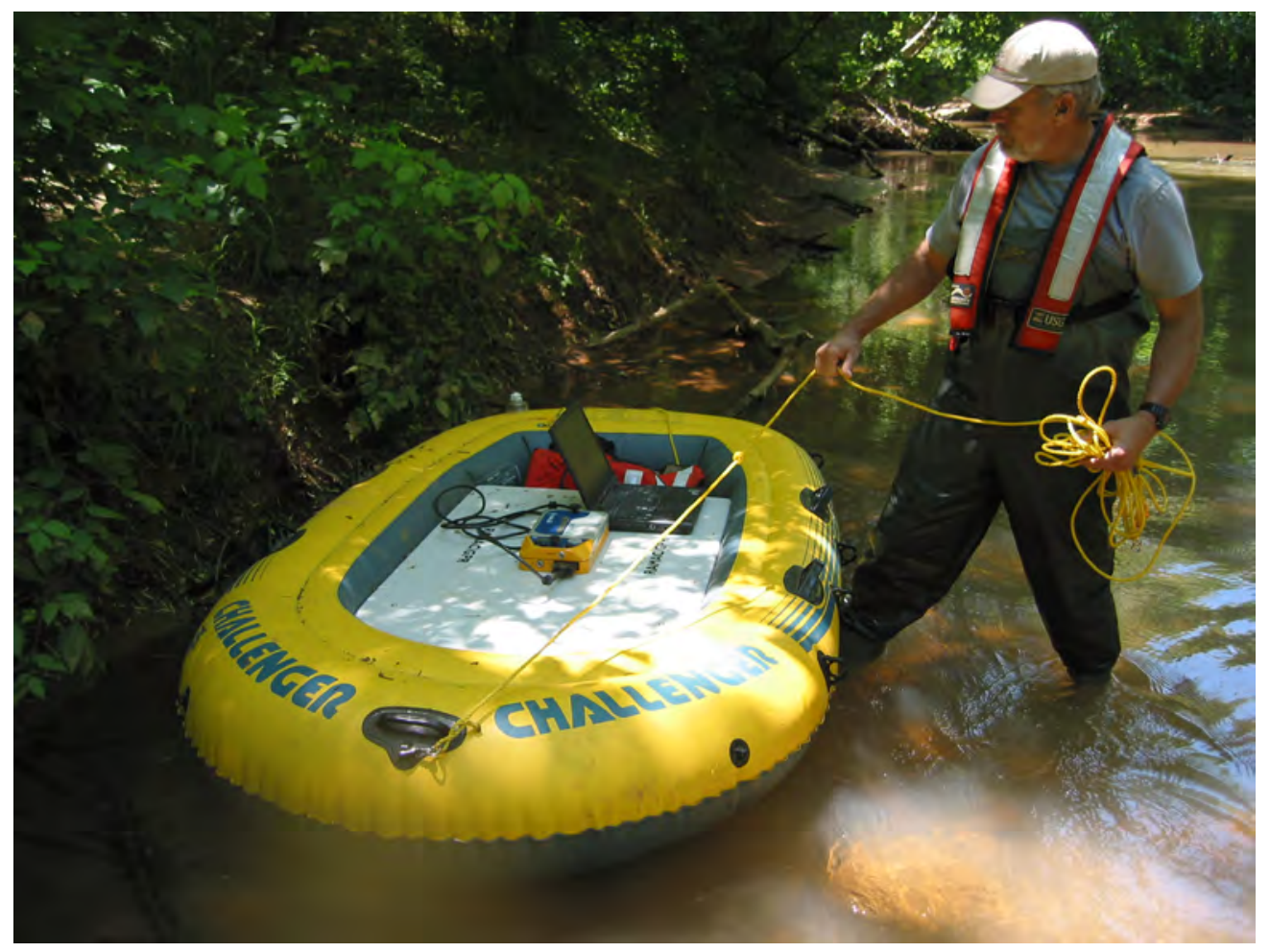

Figure 8. Collection of

subsurface channel and scour data at structure 427006200500 on Road S-62, crossing the South Tyger River in Spartanburg County, South Carolina. (Photograph by the U.S. Geological Survey, South Carolina Water Science Center, May 26, 2005.) boat with the GPR system was tied to the side of a larger boat to facilitate maneuvering in the strong currents.

Extensive GPR data collection of the areas that have potential to scour is essential. Numerous longitudinal and cross-sectional GPR traces were collected within the channel to determine the depth and areal extent of contraction and pier scour at a given site. Whereas each bridge site had unique features that determined the number and location of GPR profiles, the basic field data collected at each live-bed scour site included: (1) longitudinal traces of the streambed along the left and right sides and middle of the channel to help define the longitudinal extent of live-bed contraction scour;
(2) cross-sectional traces of the channel at the upstream and downstream bridge faces and at distances of 25, 50, 100, 150, and $200 \mathrm{ft}$ upstream and downstream from the bridge faces (in some instances, stream geometry dictated additional cross sections at 300,400 , and $1,000 \mathrm{ft}$ to ensure capturing the extent of contraction scour at the site); and (3) longitudinal traces along the left and right sides of each pier and along the pier faces to better define the extent and depth of pier scour within the channel.

When water depths were approximately $3 \mathrm{ft}$ or greater, a Lowrance ${ }^{\circledR}$ model X-16, 192-kilohertz (kHz) black and white chart-recording fathometer was used to verify the bathymetry 
data collected by the GPR system. The X-16 system is a recording depth sounder powered by a 12 -volt direct current power supply and consisted of a control unit and a lightweight transducer. The transducer has a 20 -degree beam angle that is suited for operating in shallow to medium water depths. The control unit has a built-in belt-driven chart recorder that records bathymetric data graphically on the chart paper. Pier locations and site-specific comments were written directly on the paper during data collection. The amplitude of the reflected signal was displayed using a gray scale. The fathometer delineated existing scour holes, and interestingly, the depth of penetration of the fathometer commonly equaled the thickness of refilled sediments identified in the GPR data. Even though the traces from the fathometer did not always show the same extent of infill in the scour holes indicated by GPR data, they served as a verification of the benthic surface topography shown by GPR and assisted in the interpretation of the GPR data.

After GPR data were collected, bed-material samples were taken for grain-size distribution analysis within the areas of observed scour and refill and at mid-channel upstream from the unscoured areas. A Petite-Ponar dredge sampler was deployed to collect samples from non-wadeable sites. (The Petite Ponar ${ }^{\circledR}$ sampler is used for sampling hard bottoms such as sands and clays. It is a self-tripping sampler with hinged jaws and a spring-loaded pin that releases when the sampler makes contact with the bottom.) At wadeable sites, the samples were collected by scooping sediment with a bucket. Pictures, sketches, and a general description of the site were made as needed.

To verify the accuracy and interpretation of the GPR data, additional sediment data were collected at 13 selected sites by vibracoring. Vibracoring is one of many subsurface sedimentacquisition (sediment coring) techniques. Vibracoring obtains sediment samples by vibrating a core barrel into the sediment (fig. 9). The vibrating mechanism of a vibracorer operates on hydraulic or electrical power from an external source. The vibrating mechanism is attached to the core tube and is driven into sediment by the force of gravity, enhanced by vibration energy. The core tube was driven to refusal to ensure a representative sediment sample was obtained. The core barrel was extracted using a pulley system and an aluminum tripod. The cores were taken to the office where they were cut into two halves lengthwise, and the sample was reviewed and documented.

\section{Interpretation of Field Data}

A GPR system, which can be used on land or in water, transmits short pulses of electromagnetic energy from a transmitting antenna. When used on water (as it was for this investigation), the electromagnetic energy is transmitted through the water column and into the channel bed. As the electromagnetic energy encounters soil interfaces that have differing electrical properties, a portion of the energy will be reflected back to the GPR antenna identifying the location of that interface. The remainder of the energy is transmitted further into the channel-bed material. In the case of live-bed scour, loose sediments that refill the scour hole commonly have electrical properties distinct from the in situ sediments at the bottom of the scour hole. The differing electrical properties allow the GPR system to distinguish this interface, which can be used to identify the maximum live-bed scour depth. Refilled sediments can have the same electrical properties as the in situ

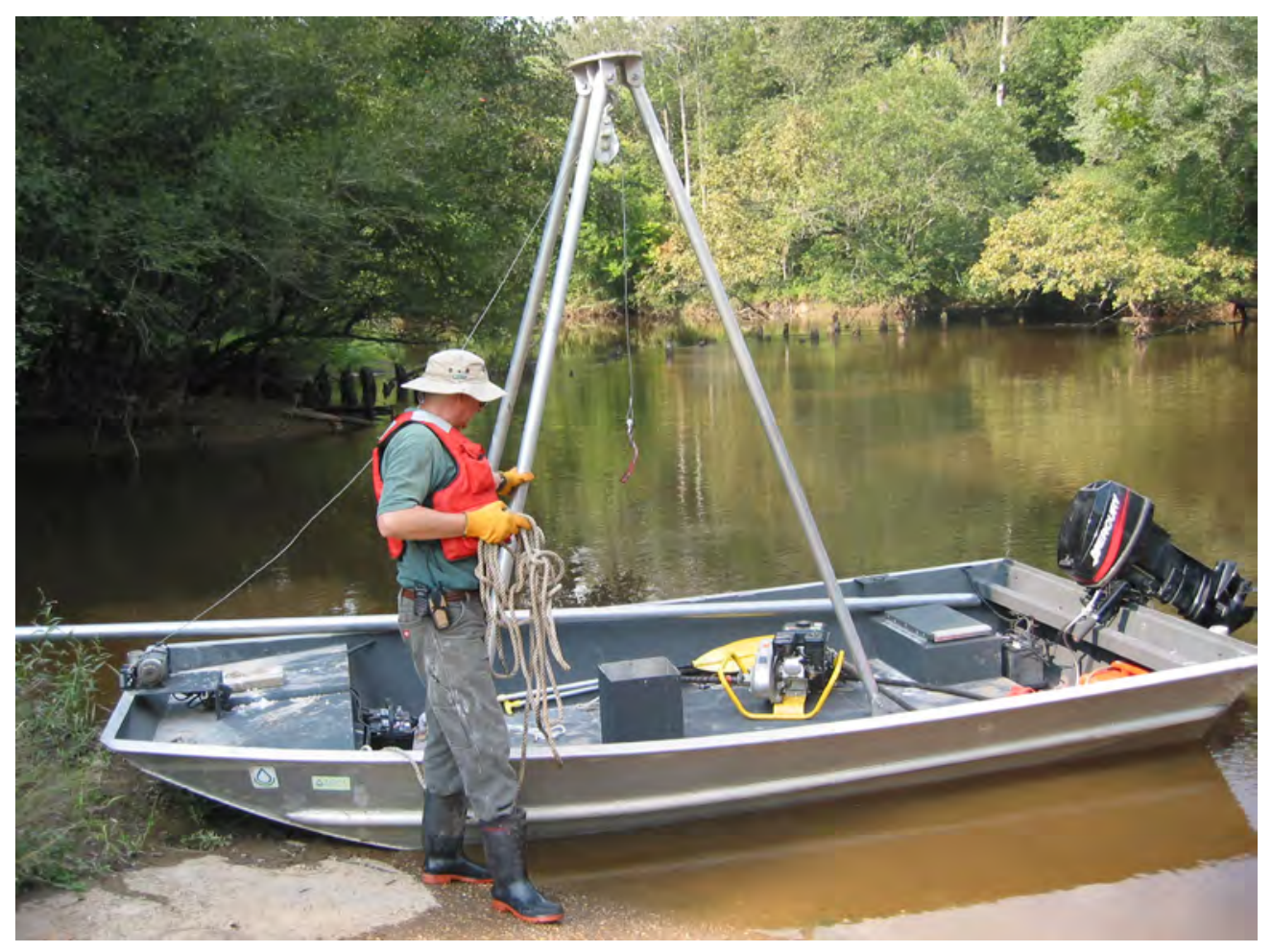

Figure 9. Vibracore system used to collect subsurface sediments. (Photograph by the U.S. Geological Survey, South Carolina Water Science Center, September 11, 2006.) 
sediments at the bottom of the scour hole, making it difficult to discern historic scour. Scour that occurs in the channels of South Carolina streams, however, commonly cuts into an older subsurface geologic formation and is refilled with loose sand. The electrical properties of the older geologic formation are typically distinct from those of the loose sands, providing a soil interface that is readily visible in GPR data, thus allowing an assessment of scour.

GPRs have been used successfully to locate and estimate scour depths associated with historic live-bed scour (Placzek and Haeni, 1995; Webb and others, 2000), but the technology has limitations. The penetration depths achieved using GPR techniques depend on the frequency of the antenna used and properties of the streambed materials. A high antenna frequency gives high resolution, but less penetration, and vice versa (MALA GeoScience, Software Manual). Penetration by GPR is effective in resistive materials (sandy sediments, freshwater) and less effective in conductive materials (clayey soils, rock, saltwater). The GPR techniques work best in shallow (20 ft or less) freshwater with granular bottom and subbottom sediments (Placzek and Haeni, 1995). The depth of penetration in conductive and resistive materials can range from less than 3 to $100 \mathrm{ft}$, respectively.

The electromagnetic data collected with a GPR system will typically have a high degree of accuracy; however, the interpretation of those data is not a precise science. Some error, therefore, is introduced into the evaluation of historic bridge-scour depths, and uncertainty is increased. At times, the clarity of the GPR data makes it difficult to interpret scour depths with confidence. Each bridge site has unique features, such as sediment characteristics, geology, and river morphology, which will determine the difficulty and accuracy of the interpretation of scour depths. The uncertainty associated with GPR scour measurements cannot be removed, but if a large sample of field data is collected, the regional range and trend of live-bed contraction and pier scour can be approximated, providing useful information for evaluating predicted and potential scour.

Soil-boring data from SCDOT bridge plans are a valuable resource to assist in the interpretation of geophysical data collected with a GPR system. The borings can be used to identify subsurface materials and the locations at which soil characteristics change, which commonly correspond to changes in the reflection patterns of the GPR data. As noted previously, live-bed scour in the channels of South Carolina streams commonly cuts into older geologic formations. The scour holes are partially or totally refilled with loose sands, forming a soil interface that is readily distinguished in the GPR data. This scour and refill pattern, in conjunction with the SCDOT bridge plan borings, can be helpful in data interpretation.

An example of a GPR longitudinal profile taken at the twin bridges on U.S. Route 501 crossing the Little Pee Dee River in Horry County, South Carolina, is shown in figure 10. The GPR longitudinal trace (moving from downstream to upstream along the middle of the channel) clearly displays an existing contraction-scour hole that begins near the upstream bridge and ends approximately $200 \mathrm{ft}$ downstream from the twin bridges. (Note: Because of varying boat speed, the

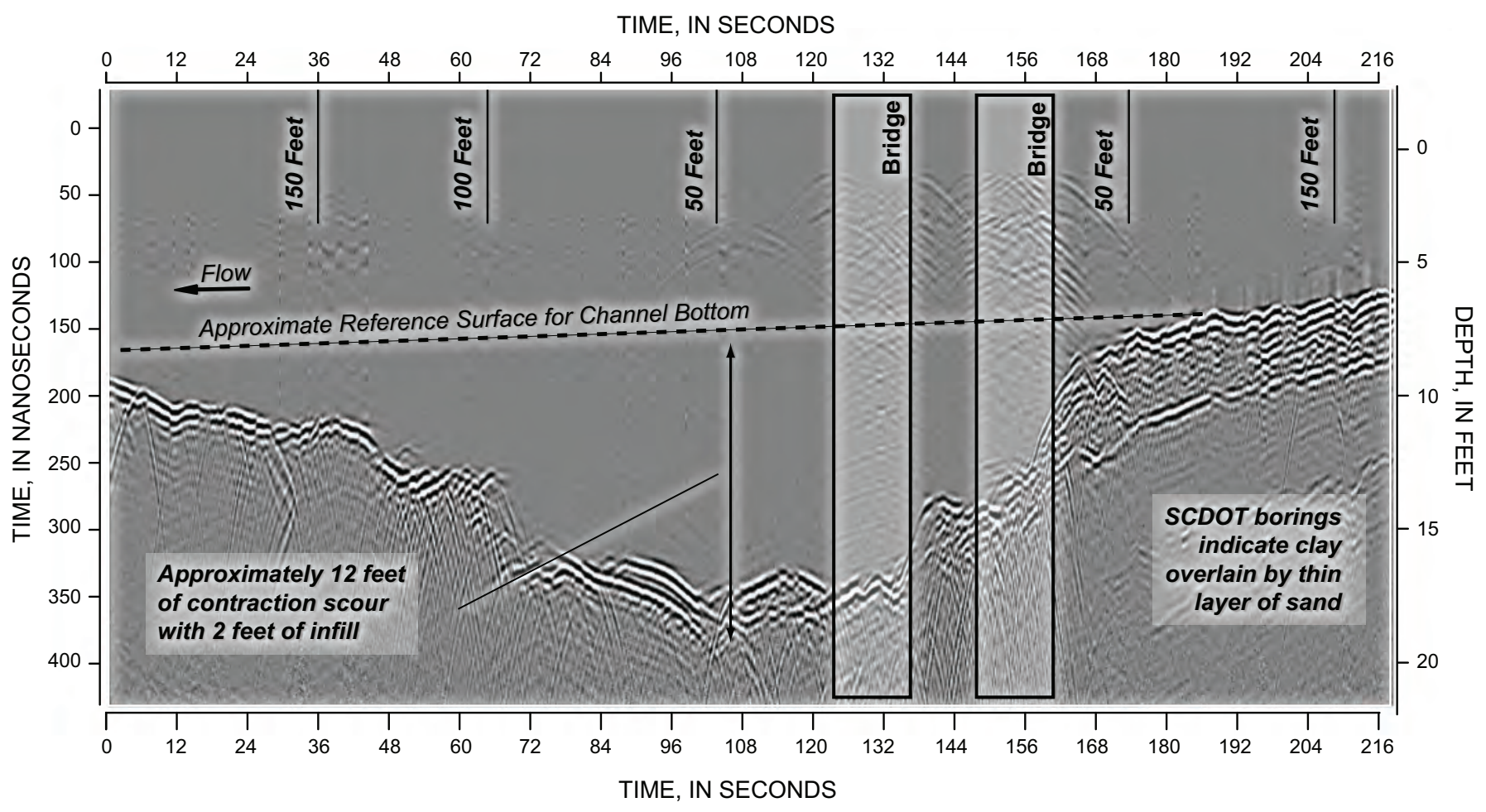

Figure 10. Example of ground-penetrating radar longitudinal profile at structure 262050110100 on U.S. Route 501, crossing the Little Pee Dee River in Horry County, South Carolina. (Depth scale through sediments is unadjusted and approximate only.) 
distance markers along the profile are not uniform.) The bridge plan borings for this Coastal Plain site indicate that a thin layer of sand on the channel bottom overlies a marine clay. The GPR profile shows a layer of material approximately 3 -ft thick that runs along the channel bed (alternating black and white lines in figure 10). Bed samples obtained during the site visit indicate that the material along the channel bed is sand; therefore, this 3-ft layer in the GPR profile is reasonably interpreted to be a sandy sediment. This interpretation is consistent with the bridge plan borings. Below the 3 -ft layer, the GPR reflection is weak, indicating the presence of a material that absorbs much of the electromagnetic energy. This weak reflection pattern is typical of a clay material, indicating that the material below the 3 -ft layer is likely a clayey soil. Again, this interpretation is consistent with the SCDOT bridge plan borings. The interface between the sandy and clayey soils indicates the maximum contraction-scour depth that has likely occurred at this site. The contraction-scour depth is approximately $10 \mathrm{ft}$ with an additional $2 \mathrm{ft}$ of sediment infill.

\section{Development of the Predicted Bridge-Scour Database}

Predicted scour was computed for each bridge using the maximum historic flow at sites where streamflow records were available and the 100-year flow where such records were not available. Methods and equations described in HEC-18

(Richardson and Davis, 2001) were used to calculate predicted live-bed pier and contraction scour. The hydraulic variables required for these equations were obtained from the WSPRO model. Computer programs were written to automate the extraction of hydraulic data from the WSPRO output files and to calculate predicted scour. Predicted scour depths and variables required to compute these depths are available in a database downloadable from http://pubs.usgs.gov/sir/2009/5099/.

\section{Estimating Hydraulic Data}

Data collected for this study represent maximum live-bed scour depths for the life of a bridge rather than scour produced by a unique flow event. The limitation of such data is that measured scour cannot be associated with the hydraulic conditions that produced the scour. Because many of the scourprediction equations are driven by hydraulic properties, such as flow depth and flow velocity, direct verification of these equations was limited in this study. In an attempt to minimize this limitation, the one-dimensional model WSPRO was used for each bridge to provide information about hydraulic conditions during large flows. Selected hydraulic data generated from WSPRO were used in the scour-prediction equations to make a limited comparison of predicted and measured scour. Hydraulic properties from WSPRO and scour-prediction variables were entered in a database, and these data, along with field data, were used to investigate relations that may help explain live-bed contraction and pier scour in South Carolina. For more details on standard techniques for developing the WSPRO models and their limitations, refer to Benedict (2003).

\section{Estimates of the Maximum Historic Flows}

In the previous investigations of clear-water scour in South Carolina (Benedict, 2003; Benedict and Caldwell, 2006), the hydraulic conditions that may have created the measured scour were approximated using the 100-year flow for all sites and the maximum historic flow at sites where data were available. Because the number of sites with estimates of the maximum historic flow were limited in the previous investigations, hydraulics based on the 100-year flow were the primary data used in the analysis, and hydraulics based on the maximum historic flow were used as supplementary data. In the current investigation (2009), however, a large percentage of the bridges (61 of 78) had estimates of the maximum historic flow; therefore, a slightly different approach was used in the analysis, in which a value for the maximum historic flow was assigned to each bridge. For the 61 sites having estimates of the maximum historic flow based on streamflow records or indirect measurements, the analysis of those sites was based on the maximum historic flow. For the remaining 17 bridges, where estimates of historic flows could not be readily determined, the 100-year flow was assumed to approximate the maximum historic flow and was used in the analysis of those sites. As noted previously (see report section "Assumption of Large Floods"), the ages for these 17 bridges range from 35 to 74 years, indicating that they have a high probability of having experienced a large flood. The bridge age range and associated probabilities provide some justification for using the 100-year flow to approximate the maximum historic flow at these sites; therefore, for purposes of this study, the term "maximum historic flow" will refer to the flow estimates at the 61 bridges based on historic flow records and the flow estimates at the 17 bridges based on the 100-year flow.

Table 1 provides a listing of the gage data and methods used to estimate the maximum historic flows at the 61 sites having historic flow records. For more details on the estimate of the maximum historic flows at these sites, refer to the report section "Assumption of Large Floods." The following methods were used to determine the maximum historic flows for the other 17 bridges. For the two bridge sites influenced by the Piedmont high-flow region (fig. 2; Sandy River at S.C. Route 72 in Chester County and Big Wateree Creek at U.S. Route 21 in Fairfield County), Feaster and Tasker (2002) suggest using the equations developed for the North Carolina Piedmont (Pope and others, 2001). The North Carolina Piedmont equations can give significantly larger peak-flow magnitudes than the South Carolina equations. This should be kept in mind when reviewing sites in this region. For the remaining 15 sites, the 100-year flow was computed using the flood-frequency 
equations and methods presented in Feaster and Tasker (2002). Predicted scour depths, based on the HEC-18 scour equations (Richardson and Davis, 2001) and the maximum historic flows, as previously defined, were compared with measured scour depths to evaluate the performance of the HEC-18 equations. In addition, the hydraulic and scour-prediction data generated with the maximum historic flows were used to investigate relations of scour in South Carolina.

\section{Predicted Live-Bed Pier Scour}

Pile bents are a common foundation for bridges in South Carolina and are the primary foundation at approximately 60 percent of the bridges studied in this investigation (fig. 11). Pile bents consist of a row of piles driven into the ground and interconnected by a bent cap at the top of the piles (fig. 12) that provides support for the bridge deck. The three types of piles observed in this study were round timber, steel $\mathrm{H}$, and square concrete (figs. 13, 14, and 15, respectively). The widths of these piles varied from 0.8 to $1.6 \mathrm{ft}$.

The other 40 percent of bridges studied were supported by piers on spread footings or on pile groups (figs. 11, 16, and 17). The piers generally are larger than piles and range in width from 1.7 to $6.0 \mathrm{ft}$. On bridges that have been widened to accommodate additional traffic lanes, a combination of piers and piles is commonly used to form a composite bent to support the bridge. Composite bents typically have piers supporting the original structure with piles added upstream and downstream from the old piers to support the newly added lanes (figs. 18 and 19). Although pile bents and piers are structurally different bridge supports, the scour processes are the same; therefore, the local scour that occurs at either support will be called pier scour throughout this report.

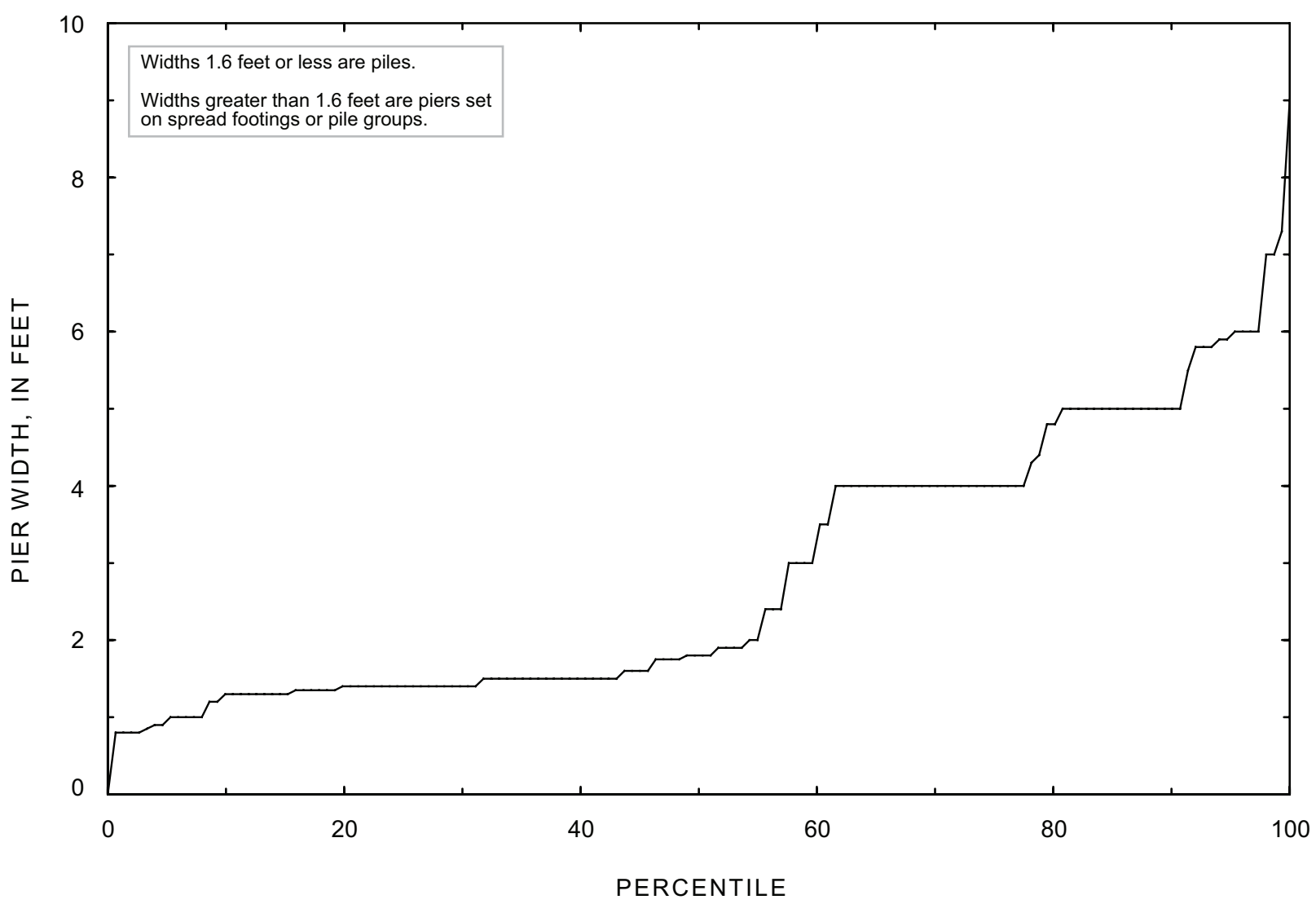

Figure 11. Distribution of pile and pier widths for selected bridges in the Coastal Plain and Piedmont Physiographic Provinces of South Carolina. 


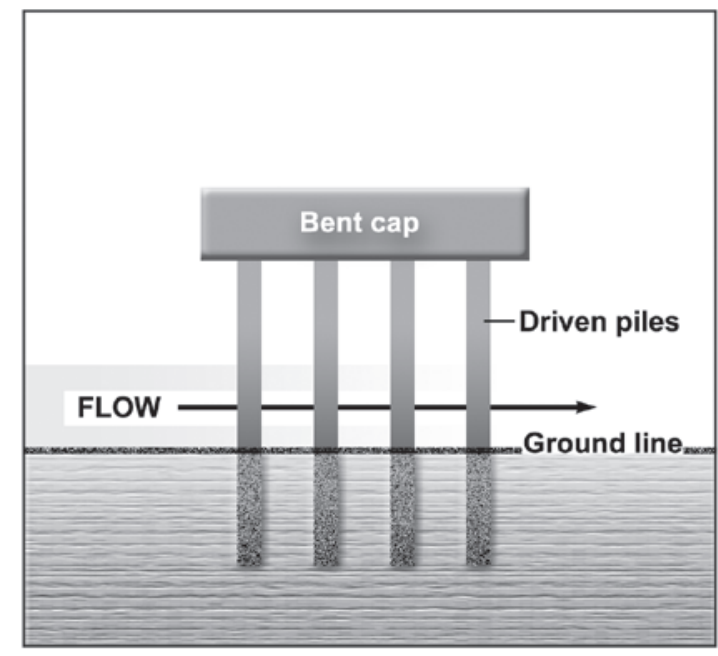

Figure 12. Generalized profile of bridge pile bent (from Benedict, 2003).

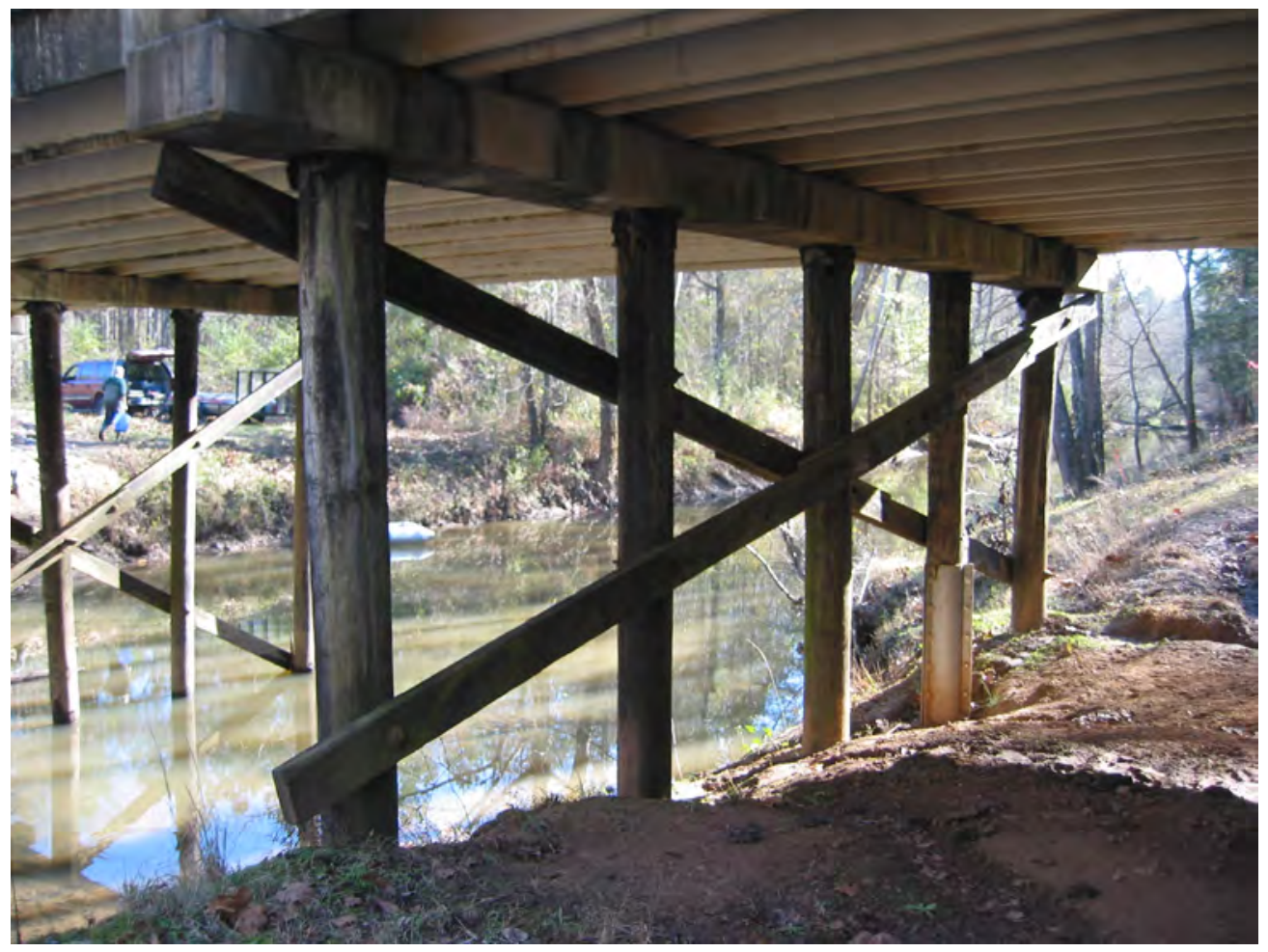

Figure 13. Timber pile bent at structure 337008500100 on Road S-85, crossing Hard Labor Creek in McCormick County, South Carolina. (Photograph by the U.S. Geological Survey, South Carolina Water Science Center, December 4, 2006.) 


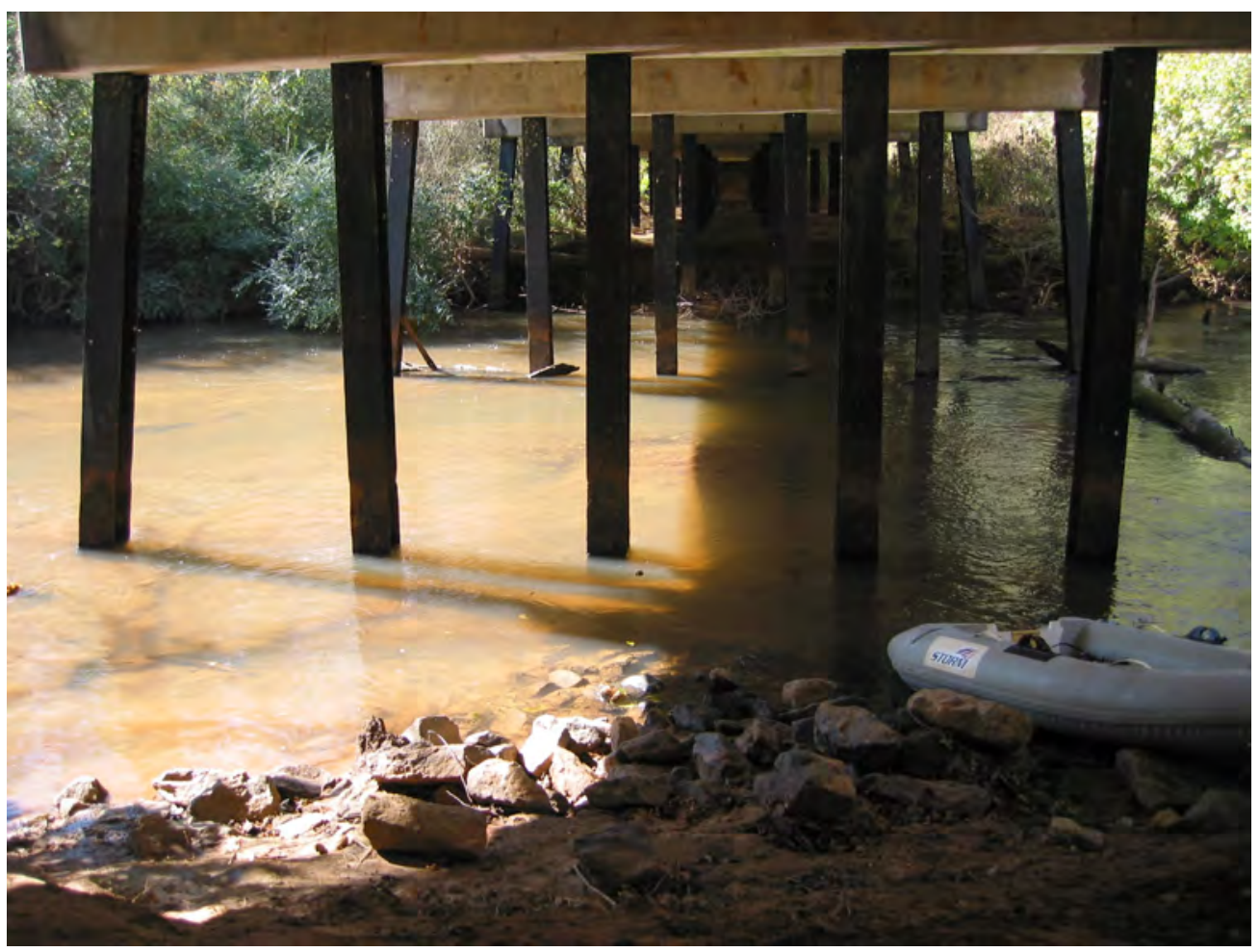

Figure 14. Steel H-pile bent at structure 237006800100 on Road S-68, crossing the Reedy River in Greenville County, South Carolina. (Photograph by the U.S. Geological Survey, South Carolina Water Science Center, October 25, 2006.)

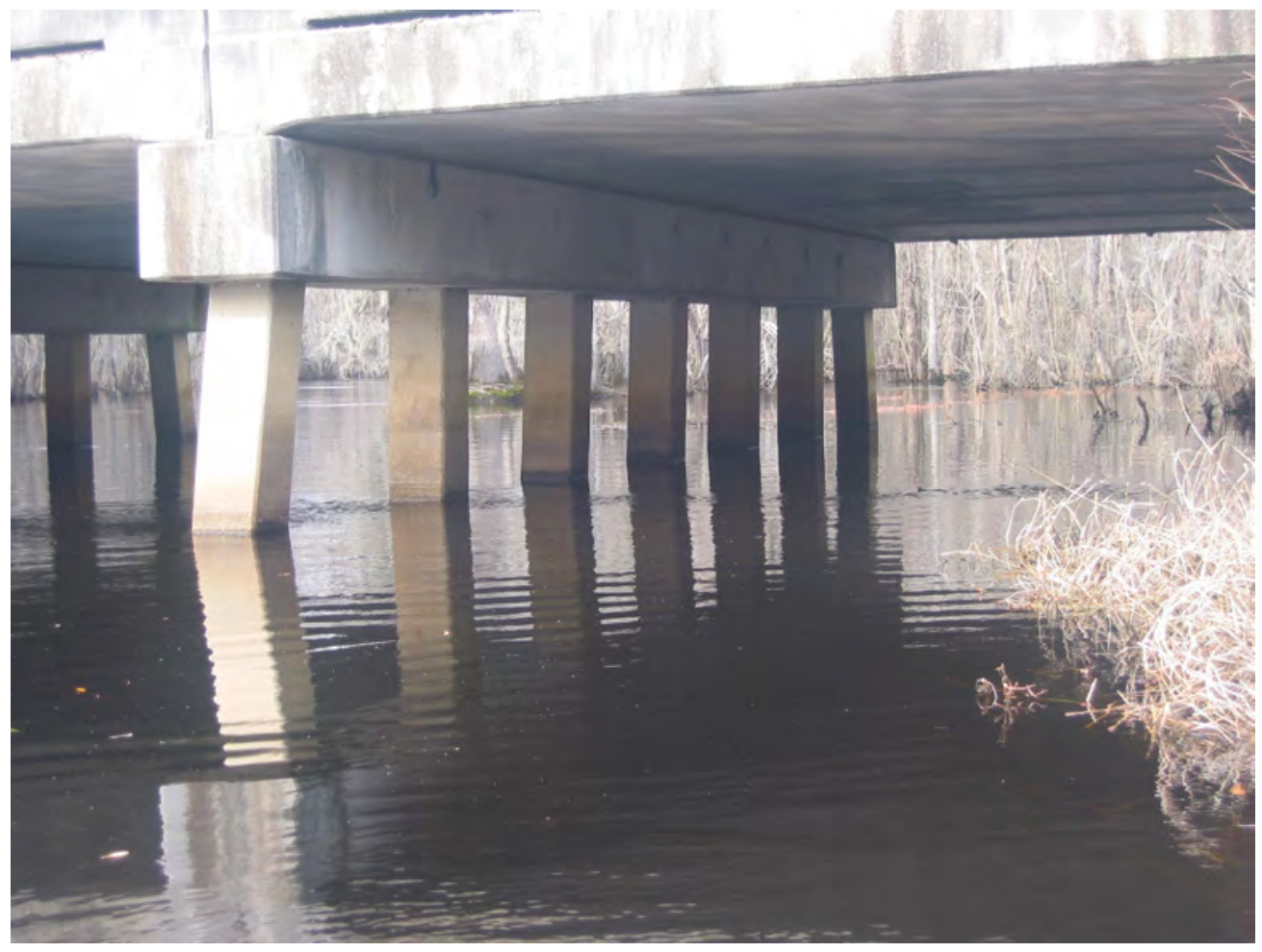

Figure 15. Square concrete pile bent at structure 174000900200 on S.C. Route 9 , crossing the Little Pee Dee River in Dillon County, South Carolina. (Photograph by the U.S. Geological Survey, South Carolina Water Science Center, March 9, 2006.) 


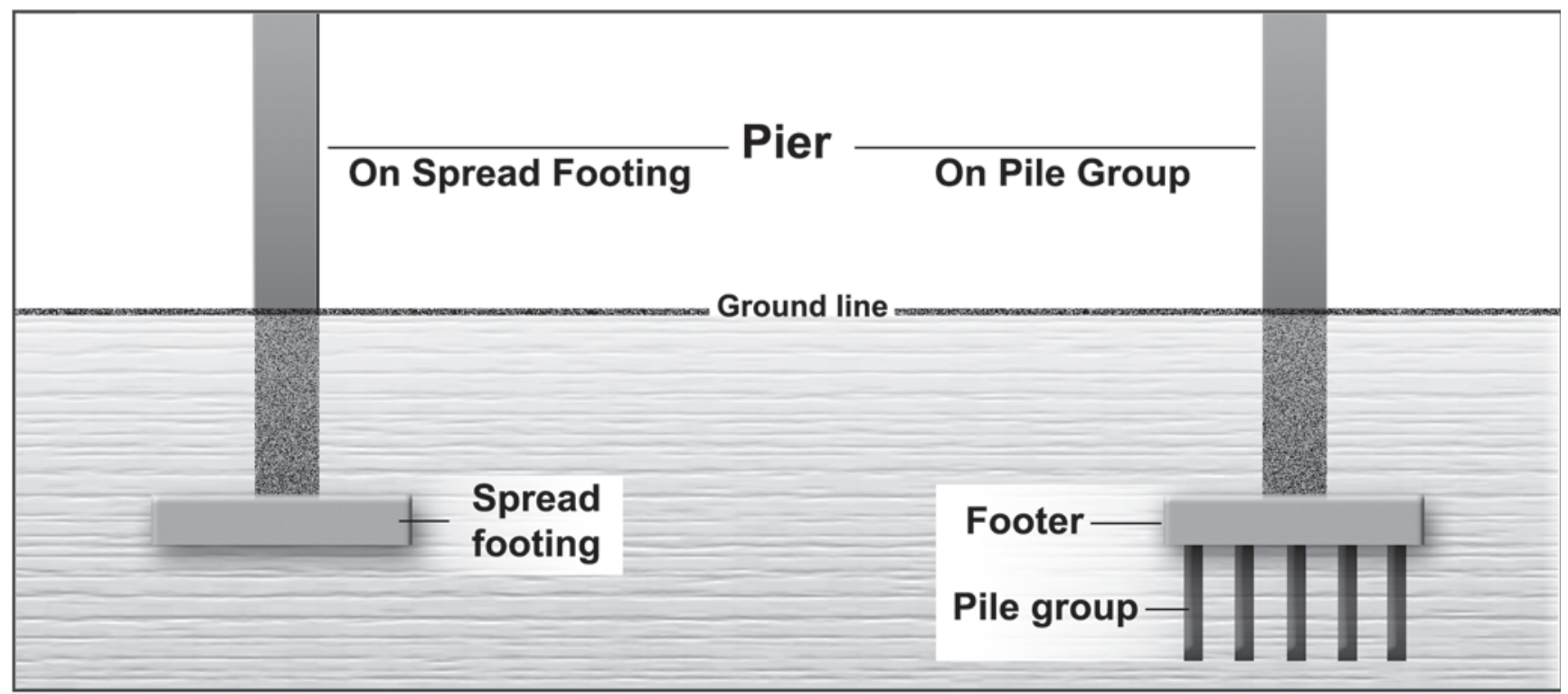

Figure 16. Generalized profile of pier on spread footing and pile group (from Benedict, 2003).

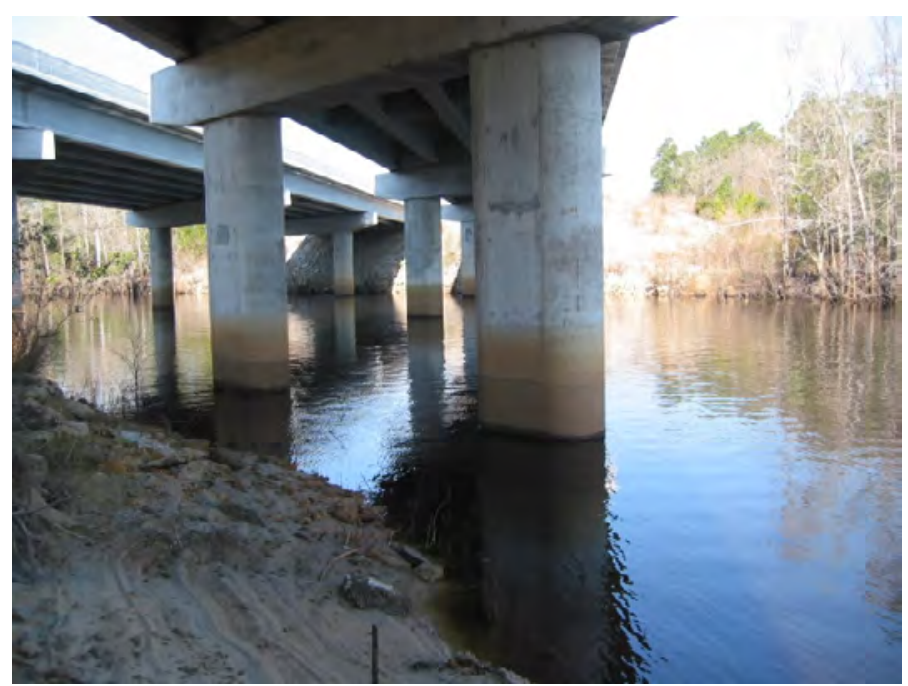

Figure 17. Pier supported on pile groups at structure 264002220100 on S.C. Route 22, crossing the Waccamaw River in Horry County, South Carolina. (Photograph by the U.S. Geological Survey, South Carolina Water Science Center, February 27, 2007.) 


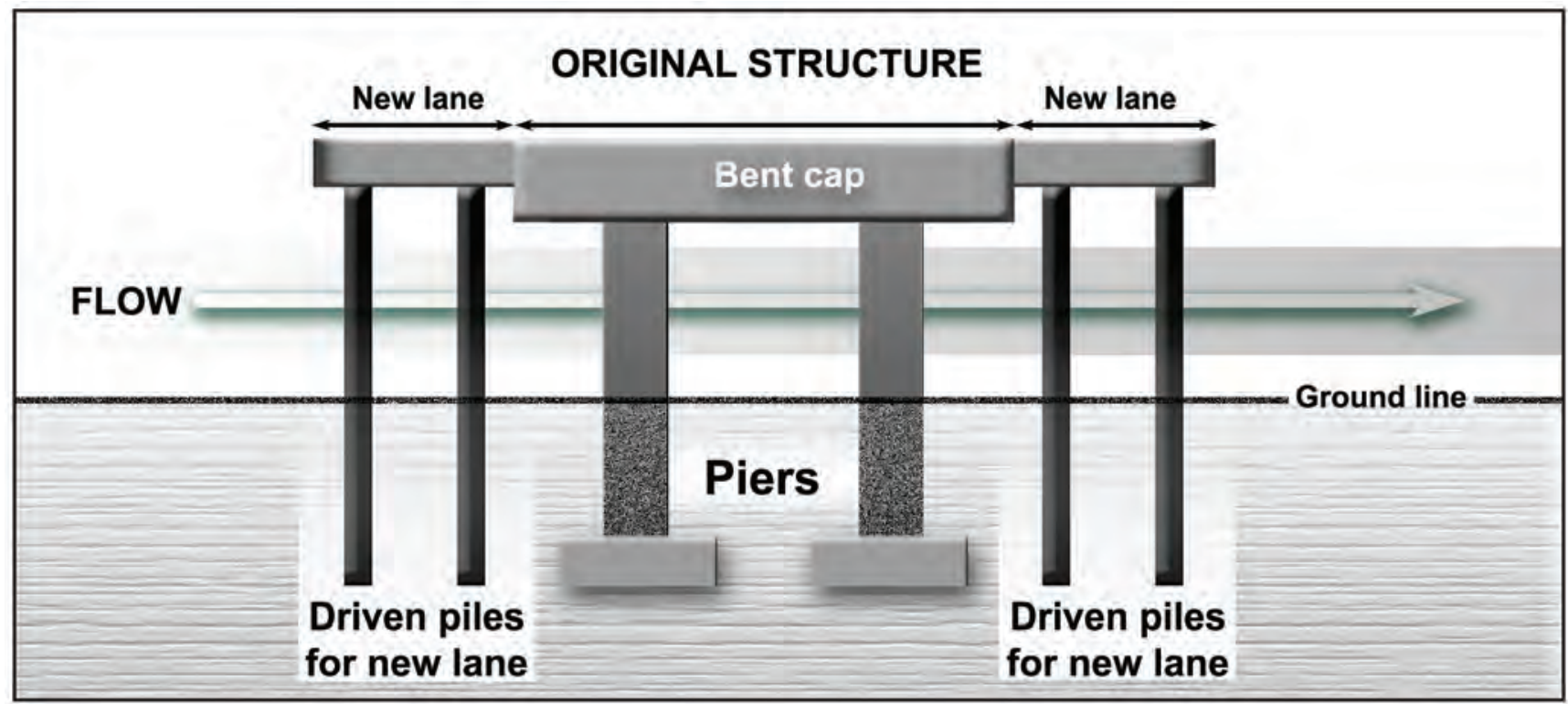

Figure 18. Generalized profile of composite bent (from Benedict, 2003).

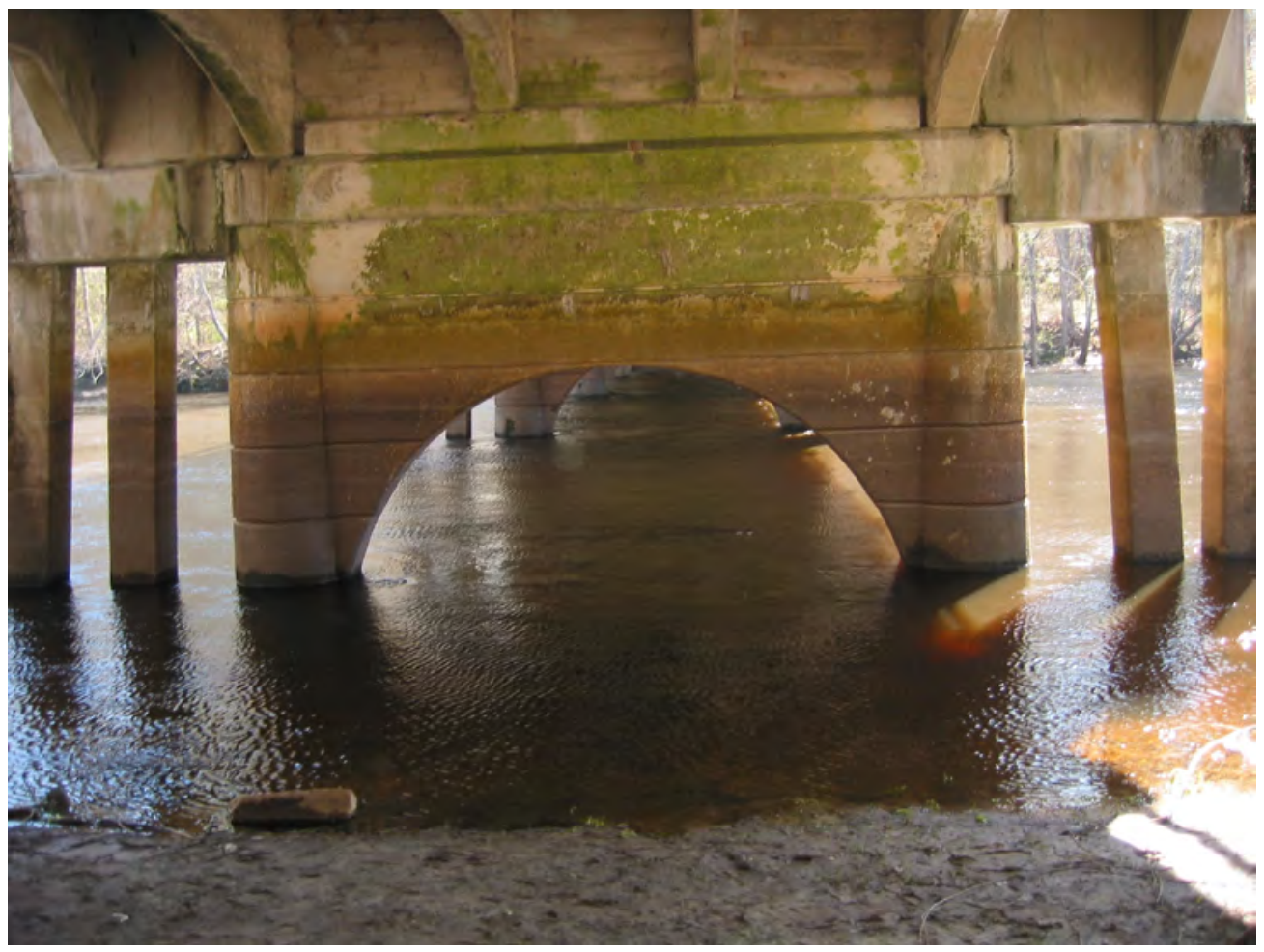

Figure 19. Composite bent at structure 182001500100 on U.S. Route 15, crossing the Edisto River in Dorchester County, South Carolina. (Photograph by the U.S. Geological Survey, South Carolina Water Science Center, March 14, 2006.) 
Predicted pier scour was computed using the HEC-18 (Richardson and Davis, 2001) equation as presented below:

$$
\frac{y_{s}}{b}=2.0 K_{1} K_{2} K_{3} K_{4}\left[\frac{y_{1}}{b}\right]^{0.35}{ }^{2} r_{1}{ }^{0.43}
$$

where

$y_{s}$ is the predicted pier-scour depth, in feet;

is the pier width, in feet;

$K_{1}$ is the dimensionless correction coefficient for pier-nose shape;

$K_{2} \quad$ is the dimensionless correction coefficient for flow angle of attack;

$K_{3}$ is the dimensionless correction coefficient for streambed conditions;

$K_{4}$ is the dimensionless correction coefficient for streambed armoring;

$y_{1}$ is the approach-flow depth, in feet; and

$F r_{1}$ is the approach-flow Froude number defined as

$$
F r_{1}=V_{1} /\left(g y_{1}\right)^{0.5}
$$

where

$V_{1} \quad$ is the mean approach velocity, in feet per second; and

$g \quad$ is the acceleration of gravity, in feet per square second.

When applying this equation to compute local scour around piers and pile bents, the following assumptions and methods were used. In general, the width of the pier or pile was determined by using the pier or pile dimension parallel with the bridge face opening and perpendicular to the direction of flow. For composite bents with columns of varying widths (figs. 18 and 19), the width of the column where the pier-scour measurement was taken was used to represent the pier width in the HEC-18 equation. Most bridges in this study had piers or piles that were constant in width along the vertical axis; however, several bridges had piers that diminished in width as elevation increased. In such cases, the pier width at the water line at low-flow conditions was used in the HEC-18 equation. Although the pier or pile bent length is not used directly in the HEC-18 equation, it is required to determine the correction coefficient for flow angle of attack. For pile and composite bents, the pier length was determined by summing the length of each pile or pier parallel with the direction of flow. For solid piers, the pier dimension parallel with the flow was used to represent the pier length.

The correction coefficient for pier-nose shape, $K_{1}$, was obtained from HEC-18 (Richardson and Davis, 2001). Pile bents with square piles were assumed to have the shape of a square-nosed pier, whereas pile bents with circular piles were treated as a group of cylinders.

The correction coefficient for flow angle of attack, $K_{2}$, also was obtained from HEC-18. To determine this coefficient an estimate must be made of the high-flow angle of attack.
This angle typically is based on visualizing the flow patterns during high-flow conditions and, as such, has a measure of subjectivity. Field inspections and USGS topographic maps were used to estimate the high-flow angle of attack. In general, a single angle of attack was determined for each bridge crossing and applied to all piers at that bridge.

In the case of multiple columns, HEC-18 recommends that if the spacing between the columns is 5 pier widths or greater, the correction coefficient for the angle of attack, $K_{2}$, should not exceed 1.2. Even though this recommendation is specific to cylindrical columns, it was applied in this study to pile bents with cylindrical or square piles (figs. 13, 14, and 15). If the spacing between piles was equal to or greater than 5 times the pile width, the $K_{2}$ skew correction coefficient was limited to 1.2. The application of this limit to multiple columns with square geometry was based on observed trends in the previous field investigation (Benedict and Caldwell, 2006) that indicated little or no influence from adjacent square piles when the piles were spaced approximately 5 or more pile widths apart. Multiple-column bents at bridges that had not been widened typically had uniform column spacings that were 5 pier widths or greater (figs. 13, 14, and 15), and the skew correction coefficient could be limited to 1.2. However, at bridges that had been widened, column spacings typically were irregular (figs. 18 and 19). In the case of irregular column spacings, the column spacings were reviewed, and judgment was used to determine if limiting the skew correction coefficient to 1.2 was appropriate.

The streambed conditions at piers and pile bents were assumed to be live bed for all cases (see report section "LiveBed Scour Conditions") because this study primarily focused on the occurrence of live-bed scour in the main channel. Therefore, the correction coefficient for streambed conditions, $K_{3}$, was set to 1.1 for all pier-scour computations. The smallest median grain size $\left(\mathrm{D}_{50}\right)$ required for applying the streambed armoring correction coefficient, $K_{4}$, is 2 millimeters ( $\mathrm{mm}$ ). The largest $\mathrm{D}_{50}$ for all bridges in the study was $1.7 \mathrm{~mm}$ with an average $\mathrm{D}_{50}$ of $0.74 \mathrm{~mm}$. The effects of bed armoring on pier scour, therefore, were considered negligible, and the correction coefficient, $K_{4}$, was set to 1.0 for all computations of pier scour.

To calculate the Froude number at a given pier, the stream-tube algorithm within the WSPRO model (Shearman, 1990) was applied to the bridge cross section to obtain estimates of the flow velocity and depth. This algorithm divides the bridge cross section into 20 stream tubes of equal conveyance and computes the flow area and the average velocity within each tube. The stream tube that corresponds with the location of a given pier or pile bent was selected, and the velocity and depth associated with that tube were used to compute the Froude number for the pier or pile bent of interest.

When complex piers have spread footings and (or) pile groups exposed to flow, HEC-18 (Richardson and Davis, 2001) provides guidance for assessing scour resulting from these conditions. In this investigation, 68 pier-scour measurements were associated with spread footings and (or) pile groups; 59 of these 68 measurements had adequate structural 
data to make a complex pier-scour computation. Following the guidance in HEC-18, 25 of the 59 complex piers required a complex pier-scour computation. Predicted scour was computed for piers where field measurements of scour were collected, and the scour-prediction variables were stored in a database. For further details on the variables stored in the database, see appendix 1 .

\section{Predicted Live-Bed Contraction Scour}

Live-bed contraction scour occurs when bed sediments upstream from a contraction are transported into the contraction-scour hole. The low-flow velocities and thick vegetation on the floodplains of most South Carolina streams limit the transport of bed materials, creating clear-water rather than live-bed scour conditions on the floodplain. In contrast, sediments in well-defined low-flow channels are available for transport and typically subjected to live-bed contraction scour within the limits of the defined channel. (For justification of this assumption, see report section "Live-Bed Scour Conditions.") For computing live-bed contraction scour, HEC-18 (Richardson and Davis, 2001) recommends the use of a modified version of the Laursen (1960) equation for live-bed scour at long contractions, which is defined as:

$$
\frac{y_{2}}{y_{1}}=\left[\frac{Q_{2}}{Q_{1}}\right]^{6 / 7}\left[\frac{W_{1}}{W_{2}}\right]^{k_{1}} \text { and }
$$

$$
y_{s}=y_{2}-y_{1}=(\text { average contraction-scour depth }),
$$

where

$y_{1} \quad$ is the average flow depth in the upstream main channel, in feet;

$y_{2}$ is the average flow depth in the main channel at the contracted section, in feet;

$Q_{1} \quad$ is the flow in the upstream main channel transporting sediment, in cubic feet per second;

$Q_{2} \quad$ is the flow in the main channel at the contracted section, in cubic feet per second;

$W_{1} \quad$ is the bottom width of the upstream main channel, in feet;

$W_{2} \quad$ is the bottom width of the main channel at the contracted section adjusted by subtracting the pier width(s) within the channel, in feet;

$k_{1} \quad$ is an exponent determined from $\omega, V_{*}$, and the tables in HEC-18;

$y_{s} \quad$ is the average scour depth, in feet;

$\omega$ is the fall velocity of the median bed material $\mathrm{D}_{50}$, in feet per second; and

$V_{*} \quad$ is the shear velocity in the upstream main channel, in feet per second, which is defined as

$$
V_{*}=\left(g y_{1} S_{1}\right)^{1 / 2}
$$

where

$$
\begin{aligned}
& g \quad \text { is the acceleration of gravity, in feet per } \\
& \text { square second; and } \\
& S_{1} \quad \begin{array}{l}
\text { is the energy grade line of the main channel, } \\
\text { in foot per foot. }
\end{array}
\end{aligned}
$$

The live-bed contraction-scour equation defines $W_{1}$ and $W_{2}$ as the bottom widths at the upstream and contracted channel, respectively. In natural channels, the bottom width is often difficult to define. In such cases, HEC-18 (Richardson and Davis, 2001) recommends the use of the width at the top of the main channel (also called the channel top width) for defining $W_{1}$ and $W_{2}$. This convention was used in all computations of live-bed contraction scour, and the channel top widths were defined as the distance between the channel banks. The flows in the upstream and contracted channels were defined as the flow bounded by the channel banks. This flow was determined by prorating the total flow by the ratio of conveyance within the channel to that of the entire cross section. The average flow depth in the upstream channel was determined by dividing the channel flow area by the channel top width. The energy grade line of the upstream channel was determined from the WSPRO model (Shearman, 1990). The $\mathrm{D}_{50}$ was determined from a grain-size analysis of a sediment grab sample obtained from the main channel. The fall velocity for the $\mathrm{D}_{50}$ was determined from an algorithm developed by the USGS (Richard J. Huizinga, U.S. Geological Survey, written commun., 1997). The algorithm uses a best-fit equation of the fall-velocity curve presented in HEC-18 (Richardson and Davis, 2001).

Predicted scour depths and the variables used to compute those depths were stored in the predicted live-bed contractionscour database. For further details on the stored variables, see appendix 1.

\section{Development of the South Carolina Live-Bed Pier-Scour Envelope Curve}

Laboratory investigations use envelope curves to display the upper limits and trends of pier scour and to develop predictive equations (Breusers and Raudkivi, 1991; Melville and Coleman, 2000). The use of envelope curves in such a manner is based on the widely accepted concept that pier-scour depths have upper limits that will rarely, if ever, be exceeded (Breusers and Raudkivi, 1991; Melville and Coleman, 2000). The frequent use of envelope curves to define upper limits of pier scour in laboratory investigations indicates that it is reasonable to use envelope curves to understand the trends of the upper limits of scour in the field. Using this approach, Benedict and Caldwell (2006) conducted a field investigation of clear-water pier scour in the Piedmont and Coastal Plain of South Carolina and developed envelope curves that defined the upper limits of clear-water pier scour in those regions. Following a similar pattern to that of Benedict and Caldwell (2006), the current investigation develops envelope curves for live-bed pier scour in the Piedmont and Coastal Plain of South Carolina. 
To develop an envelope curve that displays the range and trend of scour, the use of a dominant explanatory variable in the development of the curve is important. The following sections contain brief reviews of selected variables that have been shown to influence pier scour in the laboratory setting, and the variables' influences on live-bed pier scour in South Carolina are discussed. Based on these findings, an appropriate explanatory variable was selected for developing the South Carolina live-bed pier-scour envelope curve, and the envelope curve and its limitations are described.

\section{Selected Data Used in Analysis}

The field data in the current investigation includes 151 measurements of live-bed pier scour collected at 78 bridges. As with any dataset, some measurements have anomalies that may cause those measurements to fall outside the range for most of the data, indicating that they should be used with qualifications or excluded from the data analysis. In the current investigation, 13 measurements were noted to have anomalies associated with debris, unusual site conditions, or large pier skews. Five of these measurements were associated with significant debris that would tend to increase scour beyond that of a pier without such conditions. These measurements were excluded from the analysis. Additionally, five measurements had unusual site conditions that made the pier-scour measurement questionable. These measurements also were excluded from the analysis. Three measurements had large skews at long, solid piers, which significantly influenced the pier-scour depth and required qualification of the data. While these data could not be used in some parts of the analysis because of the large skew, the data were used to show the effect of skew at such piers and to verify the application of the pier-scour envelope curve at solid, skewed piers. Based on the data exclusions as noted above, 141 of the 151 measurements of live-bed pier scour were used in the analysis, with 42 measurements collected at 30 bridges in the Piedmont, and 99 measurements collected at 45 bridges in the Coastal Plain. Figure 20 shows the relation of measured livebed pier-scour depth to pier width and identifies the data with noted anomalies.

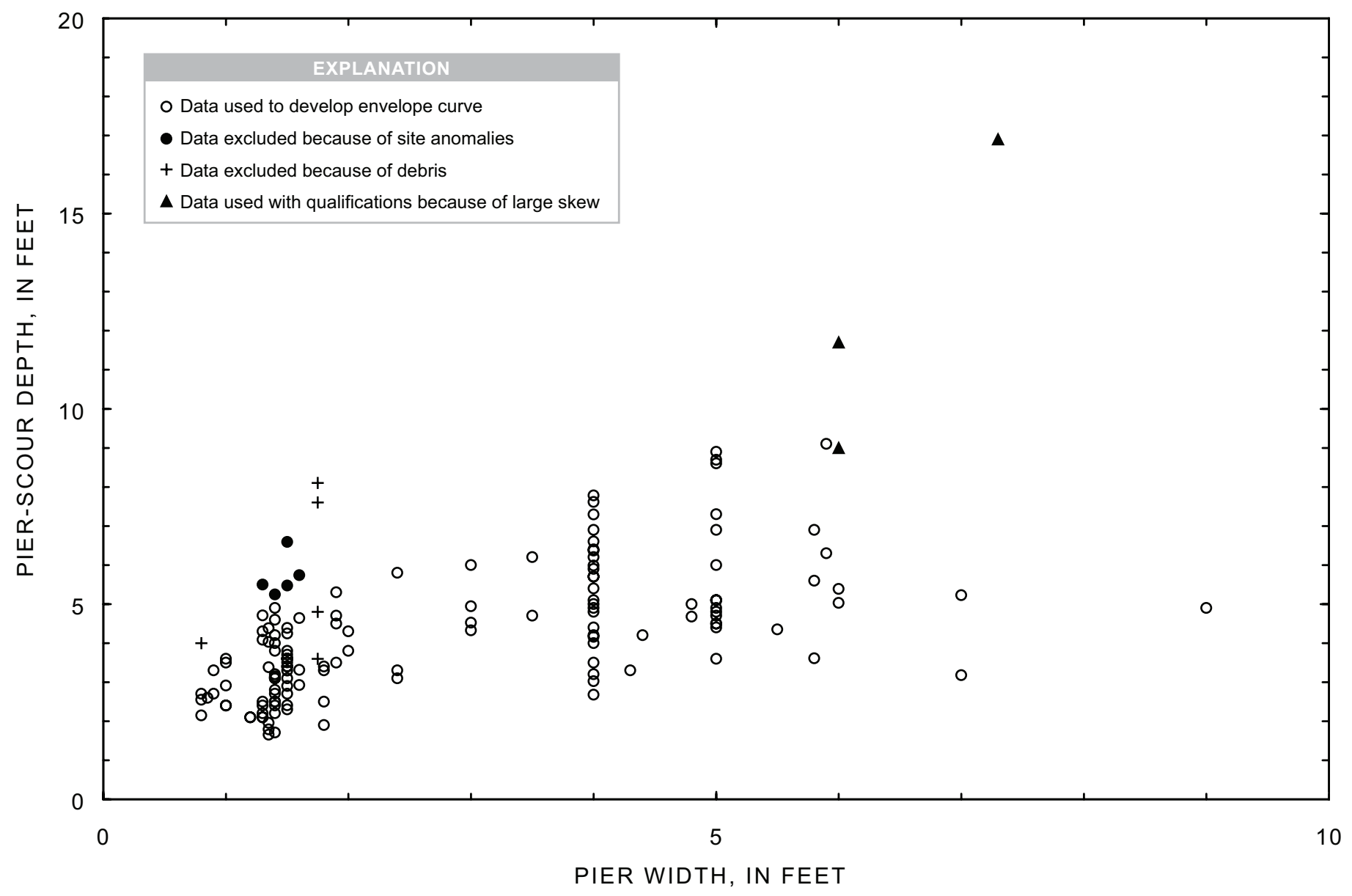

Figure 20. Relation of measured live-bed pier-scour depth and pier width for selected sites in the Piedmont and Coastal Plain Physiographic Provinces of South Carolina. 
To assess the validity of the trends observed in the South Carolina field data, selected data from the laboratory and other sources of field data were compared to the South Carolina data. The laboratory data were taken from the work of Yanmaz and Cicekdag (2001) in which 205 measurements of live-bed pier scour from previous laboratory studies were tabulated for an investigation of a composite reliability model for local pier scour. The compiled laboratory data included measurements from Chabert and Engeldinger (1956), Tarapore (1962), Laursen (1963), Shen and others (1966), Hancu (1971), White (1975), Basak and others (1977), Jain and Fischer (1979), and Melville (1984). (Note: For the remainder of the report, these laboratory data will be cited from Yanmaz and Cicekdag [2001].) The sediment sizes for the Yanmaz and Cicekdag (2001) laboratory data were similar to those of the South Carolina field data, having a range from 0.15 to $3 \mathrm{~mm}$ with a median size of $0.5 \mathrm{~mm}$. The pier widths ranged from 0.13 to $1.33 \mathrm{ft}$ with a median width of $0.33 \mathrm{ft}$. In addition to the data from Yanmaz and Cicekdag (2001), the laboratory data used to develop the original HEC-18 pier-scour equation (Richardson and others, 1991) also were used for selected comparisons to the field data. (The laboratory data used to develop the original
HEC-18 pier-scour equation were provided by J.S. Jones, U.S. Federal Highway Administration, written commun., October 2003, and will be referred to as the HEC-18 laboratory data for the remainder of the report.) The HEC-18 laboratory data include 121 measurements with sediment sizes ranging from 0.24 to $0.52 \mathrm{~mm}$ with a median size of $0.52 \mathrm{~mm}$ and pier widths that range from 0.16 to $0.5 \mathrm{ft}$ with a median width of $0.33 \mathrm{ft}$. The additional field data used for comparison with the South Carolina data were taken from the USGS National Bridge Scour Database (NBSD; U.S. Geological Survey, 2001). The selected field data from the NBSD included 92 measurements of live-bed pier scour collected at 16 bridges in 9 different States (Alaska, Arkansas, Colorado, Georgia, Indiana, Louisiana, Ohio, Minnesota, and Missouri) with grain sizes similar to those of the South Carolina field data having a range from 0.12 to $1.82 \mathrm{~mm}$ with a median size of $0.54 \mathrm{~mm}$. The pier widths range from 2.5 to $18.1 \mathrm{ft}$ with a median width of $9.3 \mathrm{ft}$. The selected NBSD data excluded measurements with significant effects from debris and pier skew.

To provide some perspective on how these data compare to each other, figure 21 shows the relation of pier width to pier-scour depth for the Yanmaz and Cicekdag (2001)

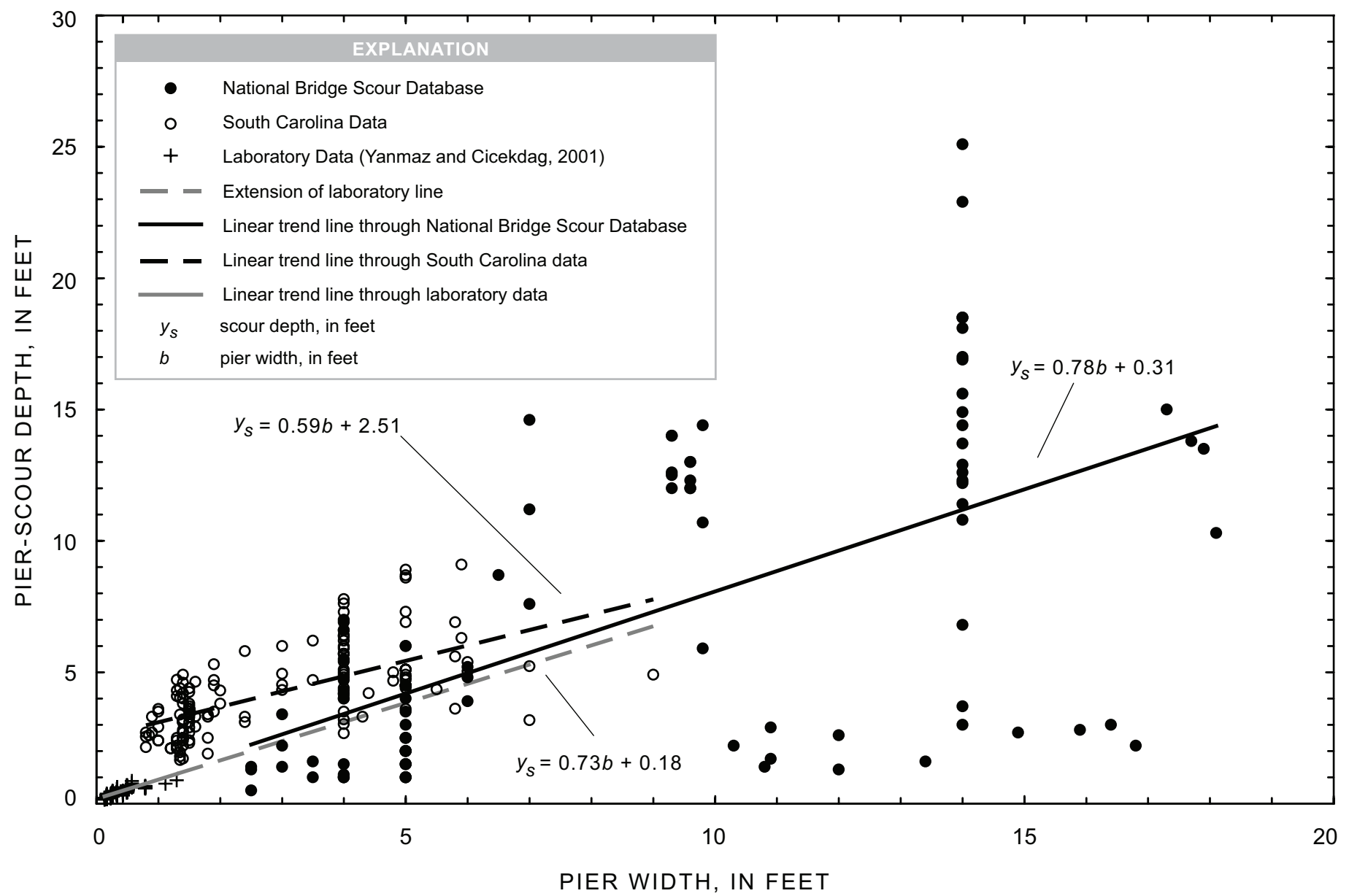

Figure 21. Relation of measured live-bed pier-scour depth and pier width for selected laboratory and field data. 
laboratory data, the NBSD data, and the South Carolina data. The trend lines for each dataset are similar, indicating that the South Carolina data are reasonable and are capturing the general trends for live-bed pier scour. However, it should be noted that the trend line for the South Carolina data is approximately 1 to $2 \mathrm{ft}$ above the lines for the laboratory and NBSD data. This difference can in part be attributed to the error associated with the GPR interpretation. This relatively small error will have little affect on the development of an envelope curve for live-bed pier scour, but should be kept in mind when reviewing trends associated with these data.

\section{Variables Influencing Pier Scour}

Local bridge scour is the erosion of streambed material from around flow obstructions, such as piers and abutments. The mechanism that causes the erosion is the combined effect of flow acceleration and the resulting vortices that are induced by the obstructions (Richardson and Davis, 2001). In the case of piers, three principal flow features that contribute to the development of scour were identified in laboratory studies. These include downflow at the face of the pier, the horseshoe vortex at the bottom of the pier, and the wake vortices downstream from the pier (Melville and Coleman, 2000; Richardson and Davis, 2001; fig. 22). The downflow acts like a vertical jet eroding sediments at the pier face. The eroded sediments then are transported by the horseshoe vortex past the pier and into the area of the wake vortices. Melville and Coleman (2000) describe the wake vortices as vacuum cleaners that can erode bed sediments downstream from the pier as well as continue the downstream transportation of the sediments eroded by the downflow. The interaction of these flow patterns creates a scour hole at a pier that is located near the pier base. Pier scour typically is classified as clear-water or live-bed scour, which designates the sediment-transport conditions along the upstream bed during the scouring process. The prevailing sediment-transport conditions will influence the rate at which pier scour develops; therefore, researchers have typically distinguished between live-bed and clear-water pier scour in their investigations. While it is important to understand the differences between live-bed and clear-water pier scour, it should be

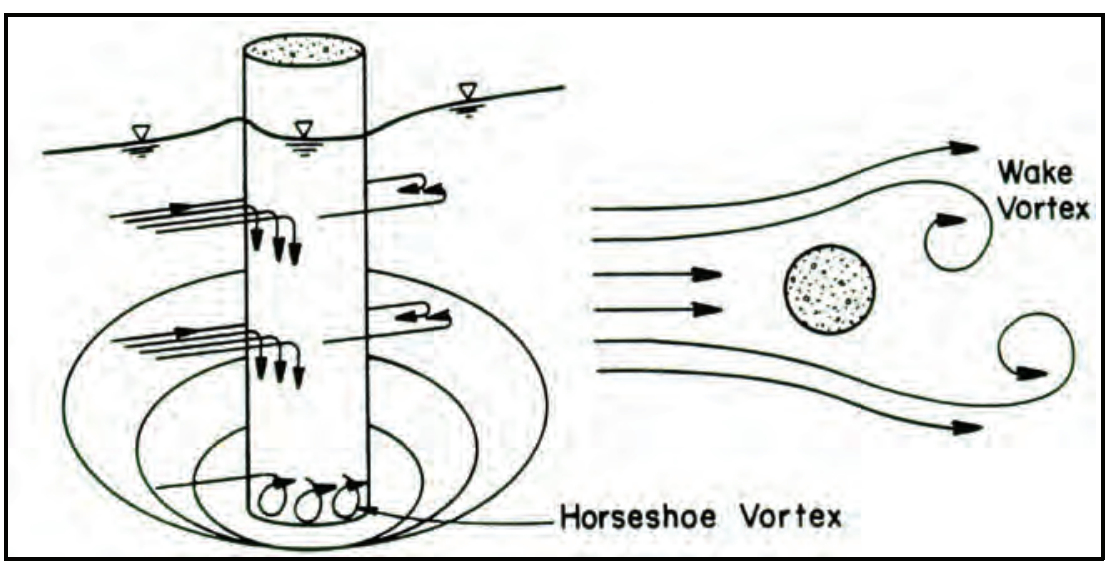

noted that the scour processes are similar and that the maximum value of scour depth associated with these types of pier scour also are similar (Melville and Coleman, 2000; Richardson and Davis, 2001). In this investigation, live-bed pier scour was a primary interest, and focus will be given to this type of scour in the review of influencing variables.

Numerous laboratory studies have been done to investigate the variables that influence pier scour. Some of the more notable publications on this topic include Laursen and Toch (1956), Neill (1964), National Cooperative Highway Research Program (1970), Breusers and others (1977), Breusers and Raudkivi (1991), and Melville and Coleman (2000). These authors generally agree that the prominent variables that influence pier scour include the velocity of approaching flow, the depth of approaching flow, sediment characteristics, pier geometry, pier alignment with flow, and flow duration. Because conditions in the field can be substantially different from the simplified conditions of the laboratory, direct application of laboratory results to the field will likely include some error. However, it is appropriate to assume that the trends in the field will be similar to those of the laboratory, making the laboratory investigations a valuable resource for understanding pier scour under field conditions. With this assumption in mind, a brief description of selected laboratory findings and how they relate to live-bed pier scour in South Carolina is presented. Because the variable pier width was used to develop the South Carolina pier-scour envelope curve, the influence of pier width on pier-scour depth will be reviewed in the section "Pier Width and The South Carolina Live-Bed Pier-Scour Envelope Curve."

\section{Estimation of Hydraulic Variables}

Hydraulic variables associated with the field measurements in this investigation were determined using the onedimensional model, WSPRO (Shearman, 1990), in conjunction with the estimates of the maximum historic flows, as defined previously (see report section "Estimates of the Maximum Historic Flows").

The hydraulic variables obtained from the WSPRO models (Shearman, 1990) provide valuable information about hydraulic trends at each bridge, but should be viewed as approximate rather than measured hydraulic data. The approximated hydraulic data likely will introduce some error into the analysis for this investigation. However, the large number of field measurements used in this study, in conjunction with the maximum historic flows known at 61 bridges, provides a reasonable means for evaluating the trends of live-bed pier and contraction scour in South Carolina.

Figure 22. Illustration of scour at a cylindrical pier (from Richardson and Davis, 2001). 


\section{Time and Flow Duration}

Laboratory investigations indicate that the development of a pier-scour hole is time dependent (Breusers and Raudkivi, 1991; Melville and Coleman, 2000; Richardson and Davis, 2001). As scour initially begins, the rate at which the pierscour depth increases is relatively fast. As time progresses, the rate of scour diminishes, and the scour depth asymptotically approaches an equilibrium condition where changes in pierscour depth are minimal. Once equilibrium-scour conditions are attained, flow duration has little influence on scour depth and is no longer a significant explanatory variable. Figure 23 shows a generalized relation of pier-scour depth to time for clear-water and live-bed scour conditions. While these types of pier scour can attain the same equilibrium-scour depth, the figure highlights the differences in time dependency between clear-water and live-bed pier scour. In the case of clear-water pier scour, the time to reach equilibrium-scour depth in the laboratory requires days. In contrast, live-bed pier scour in the laboratory may reach equilibrium-scour depth in hours. These trends have implications for pier scour in the field, where streamflows associated with floods often peak and recede within hours rather than days. For clear-water pier scour, short flow durations for floods make it improbable that equilibriumscour depths, as observed in the laboratory, will be attained in the field (Melville and Coleman, 2000). In the case of live-bed pier scour, where equilibrium conditions are reached more

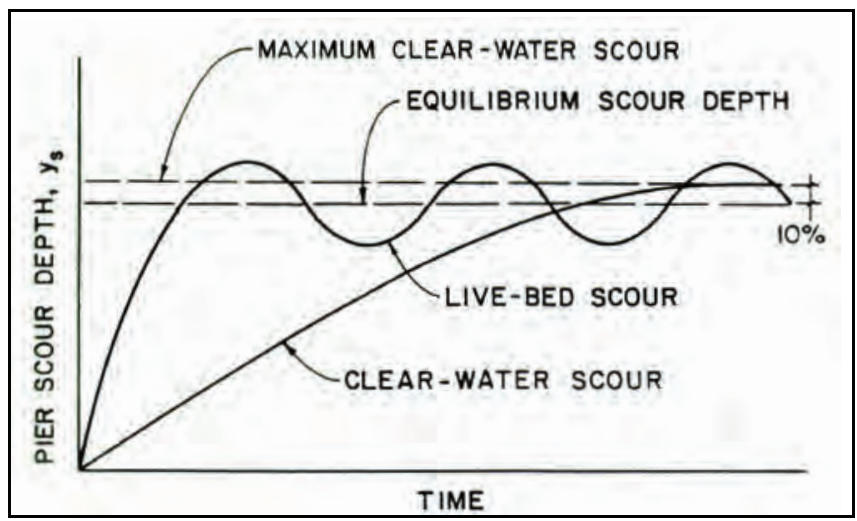

Figure 23. Generalized relation of pier-scour depth to time (from Richardson and others, 2001).

quickly, the flow durations associated with floods likely are sufficient to attain a state of equilibrium similar to those in the laboratory.

To provide some understanding of flow durations under field conditions in South Carolina, Benedict (2003) used regionalized dimensionless hydrographs (Bohman, 1990) to estimate flow durations associated with the 100-year flow. Figure 24 shows regionalized dimensionless hydrographs for a $200-\mathrm{mi}^{2}$ basin in the lower Coastal Plain and Piedmont of

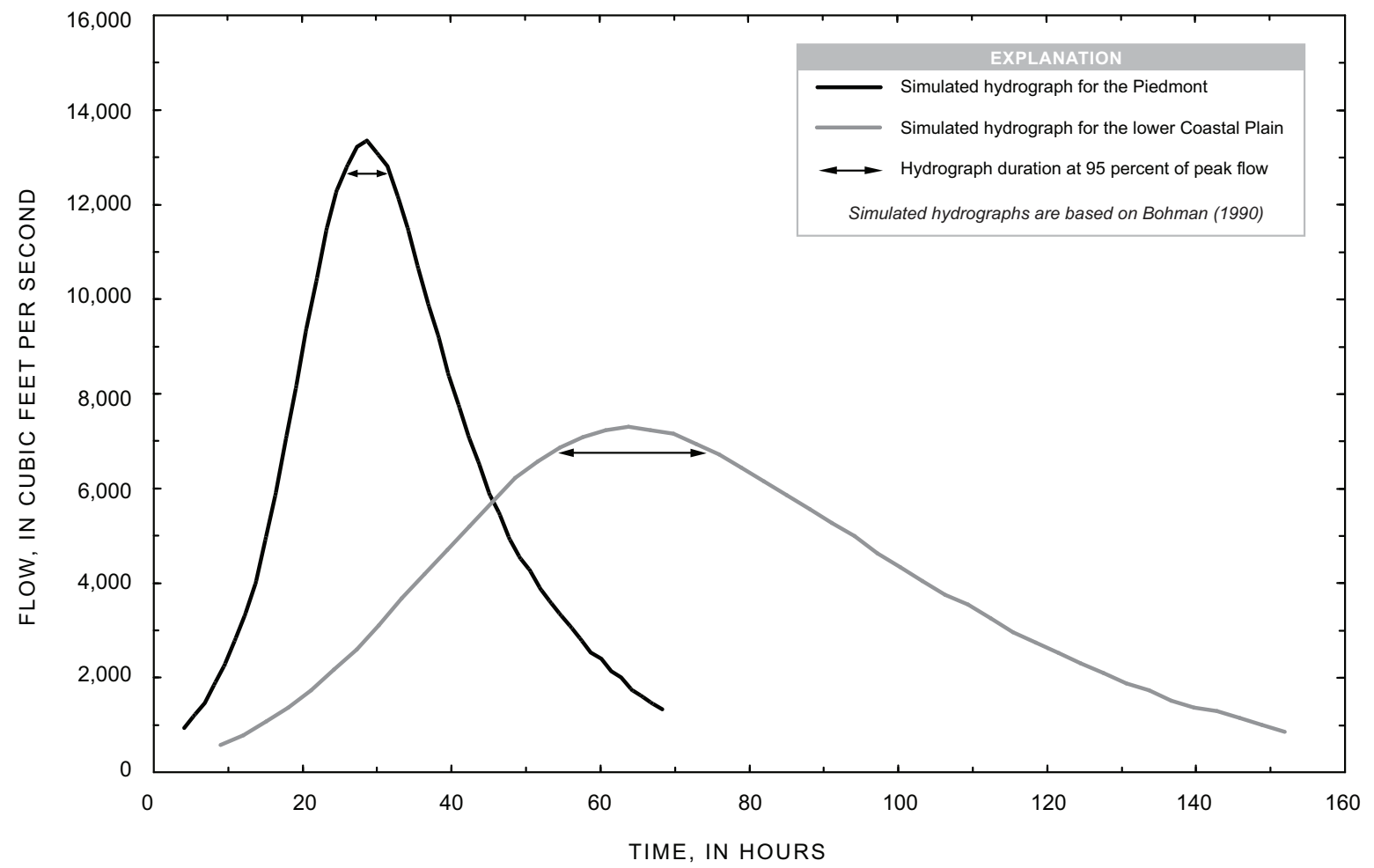

Figure 24. Simulated 100-year-flow hydrographs for 200-square-mile basins in the Piedmont and lower Coastal Plain Physiographic Provinces of South Carolina (from Benedict, 2003). 
South Carolina, highlighting that Piedmont hydrographs have significantly larger peaks and shorter durations than those of the Coastal Plain. Assuming that the hydrograph duration for 95 percent of the 100-year flow (see fig. 24 for definition) represents the duration of the 100-year peak flow, Benedict (2003) showed that South Carolina drainage basins smaller than 2,000 $\mathrm{mi}^{2}$ will have sustained flow durations of approximately 3 to 21 hours in the Piedmont and 12 to 40 hours in the Coastal Plain for flows approaching the 100-year flow magnitude (fig. 25). Such flow durations likely are sufficient to attain live-bed equilibrium pier-scour conditions. Drainage areas for bridges used in the current study range from 17.2 to $9,360 \mathrm{mi}^{2}$ (table 1), indicating that the flood-flow durations at these sites likely are sufficient to attain live-bed equilibrium conditions. Because flood-flow durations at the study sites likely are sufficient to attain live-bed equilibrium conditions, the live-bed pier-scour depths collected in this study should approximate equilibrium-scour depths associated with the historic floods occurring at each site. Additionally, because the collected data will likely reflect equilibrium-scour depths, flow duration should not be a strong explanatory variable and can be neglected in the development of an envelope curve that may help explain the upper limits of live-bed pier scour in South Carolina.

To provide perspective on the relation of live-bed pierscour depth and peak-flow duration for field data, a graphical relation of measured live-bed pier-scour depth and the estimated peak-flow duration for the maximum historic flows in the Coastal Plain and Piedmont of South Carolina is shown in figures $26 A$ and $B$, respectively. The peak-flow duration for each site was estimated by using methods presented in Bohman (1990), assuming that the hydrograph duration at 95 percent of the historic flow represents the duration for the historic peak flow. Because pier width is a dominant explanatory variable, data were grouped by selected pier widths. Figure 26 shows a large scatter of data within the pier-width categories and appears to indicate, especially in the Coastal Plain, that pier-scour depth generally increases with flow duration. A closer review, however, indicates that this trend is probably more a function of pier width than of flow duration, and a brief explanation follows.

Flow duration is proportional to drainage area (fig. 25), so that as drainage area increases, flow duration increases. Therefore, if the variable drainage area were substituted for flow duration in figure 26, there would be a similar pattern in which pier-scour depth increased with drainage area. (Mueller [1996] also found such a relation in the NBSD data.) As drainage area increases, channels become wider, requiring longer bridge spans and thus wider piers. The trend in the field data is that pier width tends to increase with drainage area. This trend is evident in figure 26 where longer flow durations, and thus larger drainage areas, are associated with wider piers. The influence of flow duration on pier-scour depth is not properly displayed on figure 26 because scour depth increases with pier

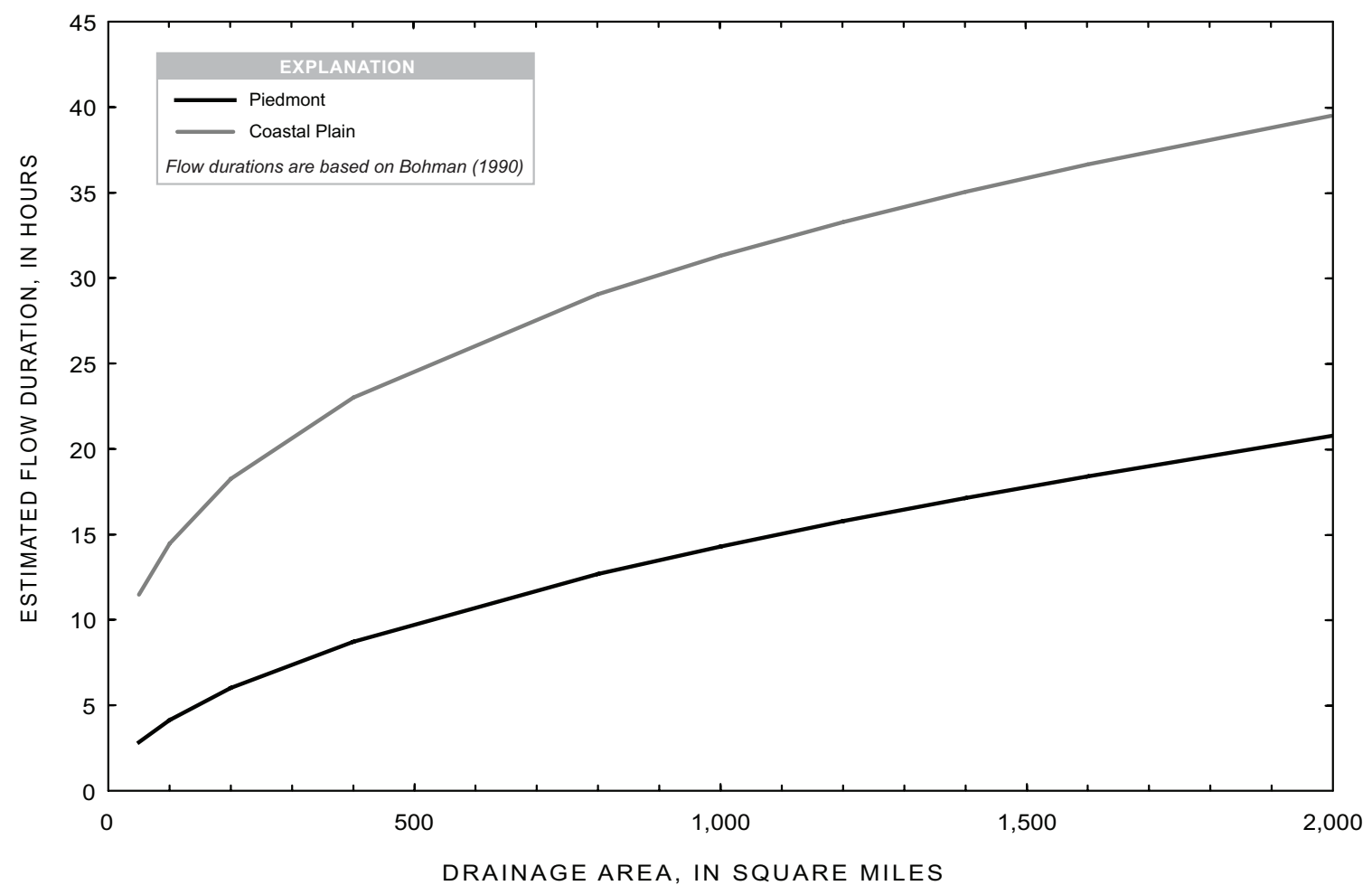

Figure 25. Hydrograph durations at 95 percent of the peak flow estimated from simulated 100 -yearflow hydrographs for various basin sizes in the Piedmont and lower Coastal Plain Physiographic Provinces of South Carolina (from Benedict, 2003). 
A.

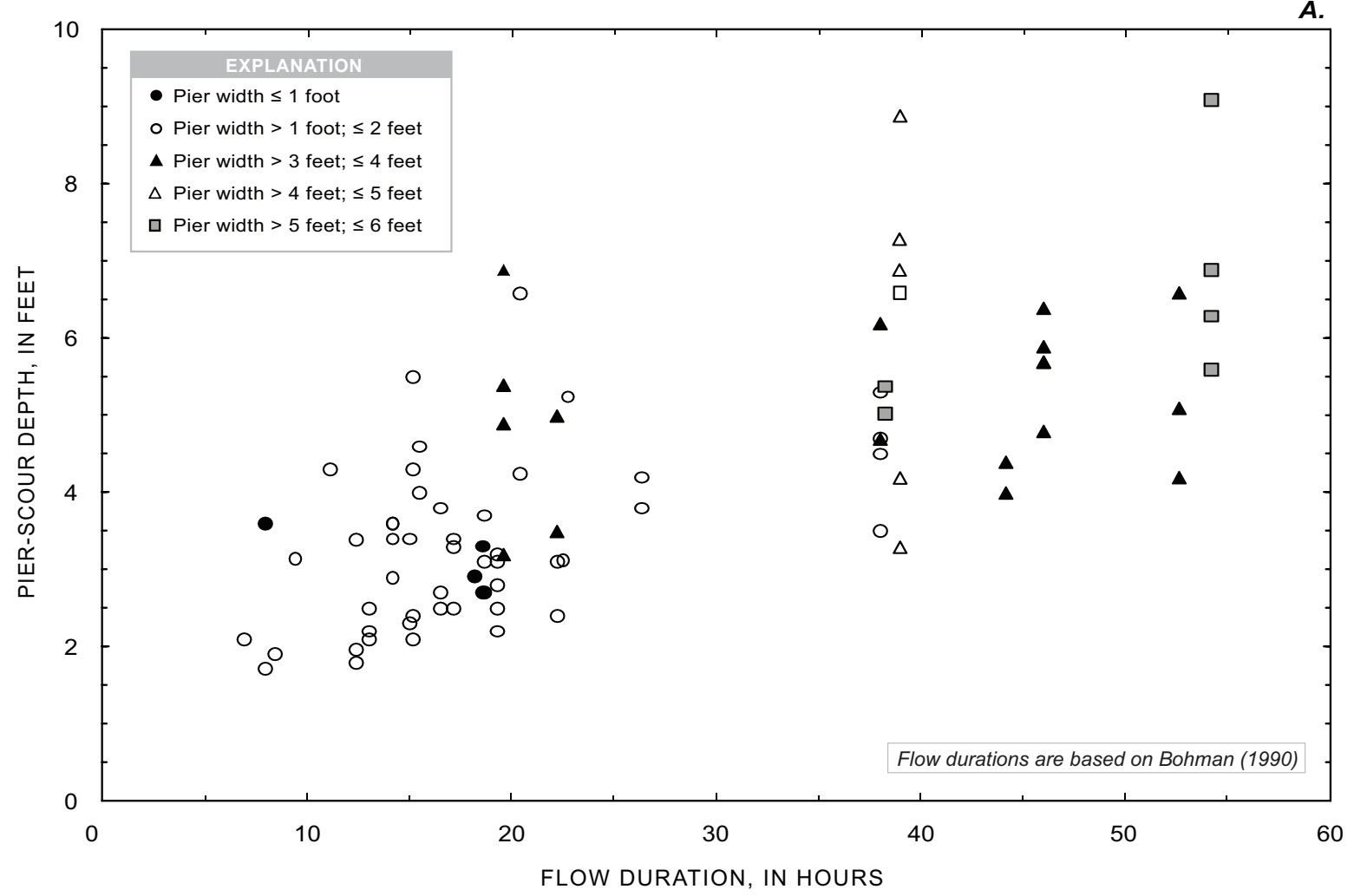

B.

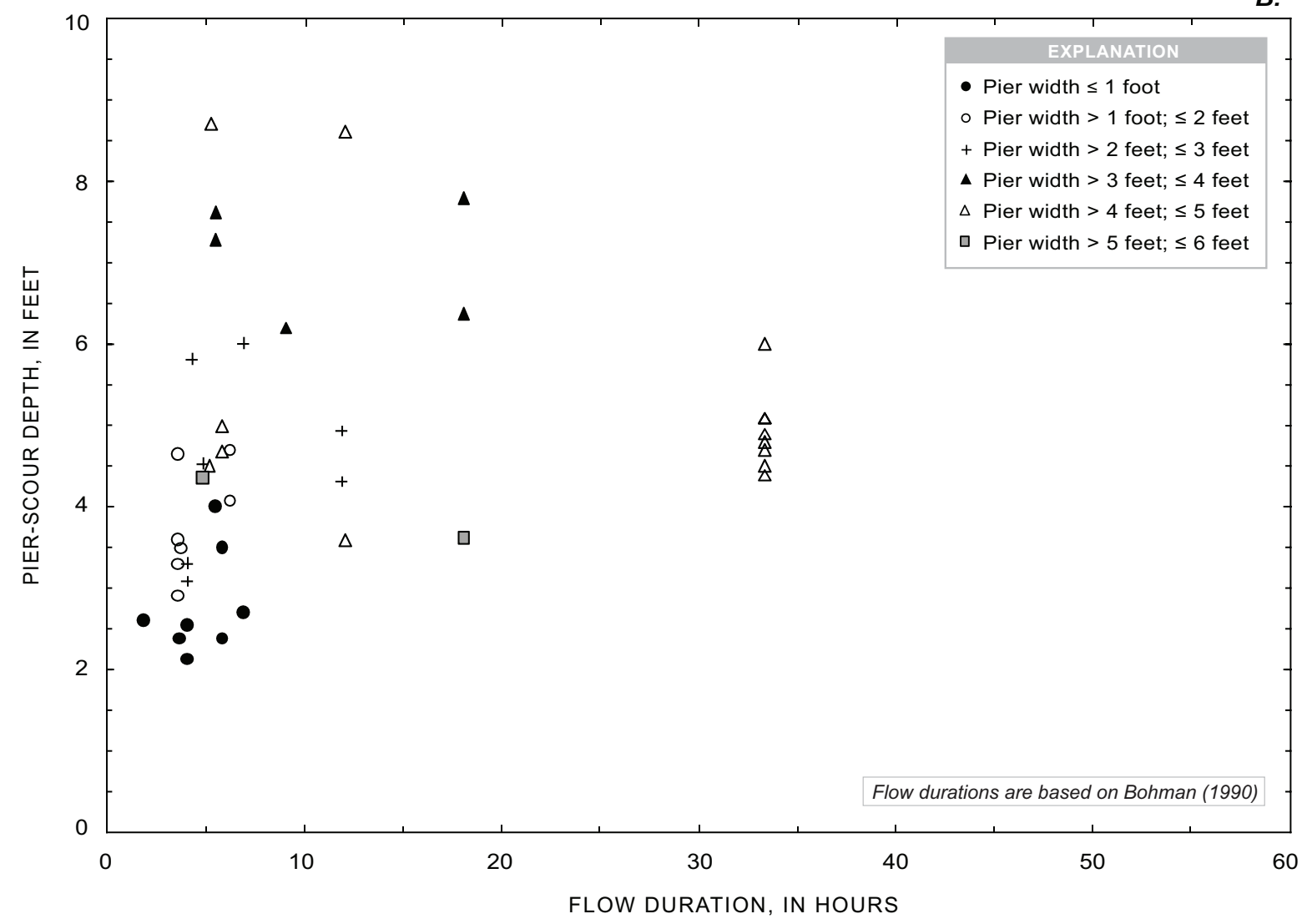

Figure 26. Relation of measured live-bed pier-scour depth and the estimated peak-flow duration for historic peak flows at selected sites in the (A) Coastal Plain and (B) Piedmont Physiographic Provinces of South Carolina. 
width and pier width and flow duration tend to increase with drainage area. The data grouped by pier width have significant scatter, but the trend of increasing scour depth with flow duration is not as prominent in the pier groups, indicating that scour depth for common pier widths is not as strongly influenced by flow duration. This is most evident for the grouped data for pier widths greater than $3 \mathrm{ft}$ and less than or equal to $4 \mathrm{ft}$ for the Coastal Plain (fig. 26A). While it is likely that pier width is a primary variable influencing the trends seen in figure 26, flow duration and thus drainage area size may also have some bearing on the increased scour. Therefore, drainage area size should be kept in mind when qualitatively evaluating the potential for pier scour.

\section{Flow Velocity}

A typical laboratory relation showing the general influence of flow velocity on equilibrium-scour depths for uniform and non-uniform sediments is shown in figure 27 (Breusers and Raudkivi, 1991; Melville and Coleman, 2000). The vertical axis represents the relative scour, which is defined as the equilibrium pier-scour depth divided by the pier width. The horizontal axis represents flow intensity, which is defined as the ratio of the average approach flow velocity to the critical velocity required to initiate motion for a given sediment size. The relation in figure 27 indicates that for uniform sediments clear-water pier-scour depth increases almost linearly with increasing approach flow velocity. When the flow velocity reaches the critical velocity of the bed sediments (flow intensity is equal to 1 ), scour depth reaches a maximum called the threshold peak (Melville and Coleman, 2000), and the scour process transitions from clear-water to live-bed conditions. At this transition, bed sediments begin to move along the bed and into the scour hole, and pier-scour depth initially decreases and then begins to increase again to a second peak called the live-bed peak (Melville and Coleman, 2000). The live-bed peak occurs near a flow intensity of 4 and is slightly less than the magnitude for the threshold peak (Breusers and Raudkivi, 1991; Melville and Coleman, 2000). The fact that threshold and live-bed peaks for uniform sediments are close in magnitude implies that the maximum equilibrium live-bed scour depths for uniform sediments is not strongly influenced by flow velocity.

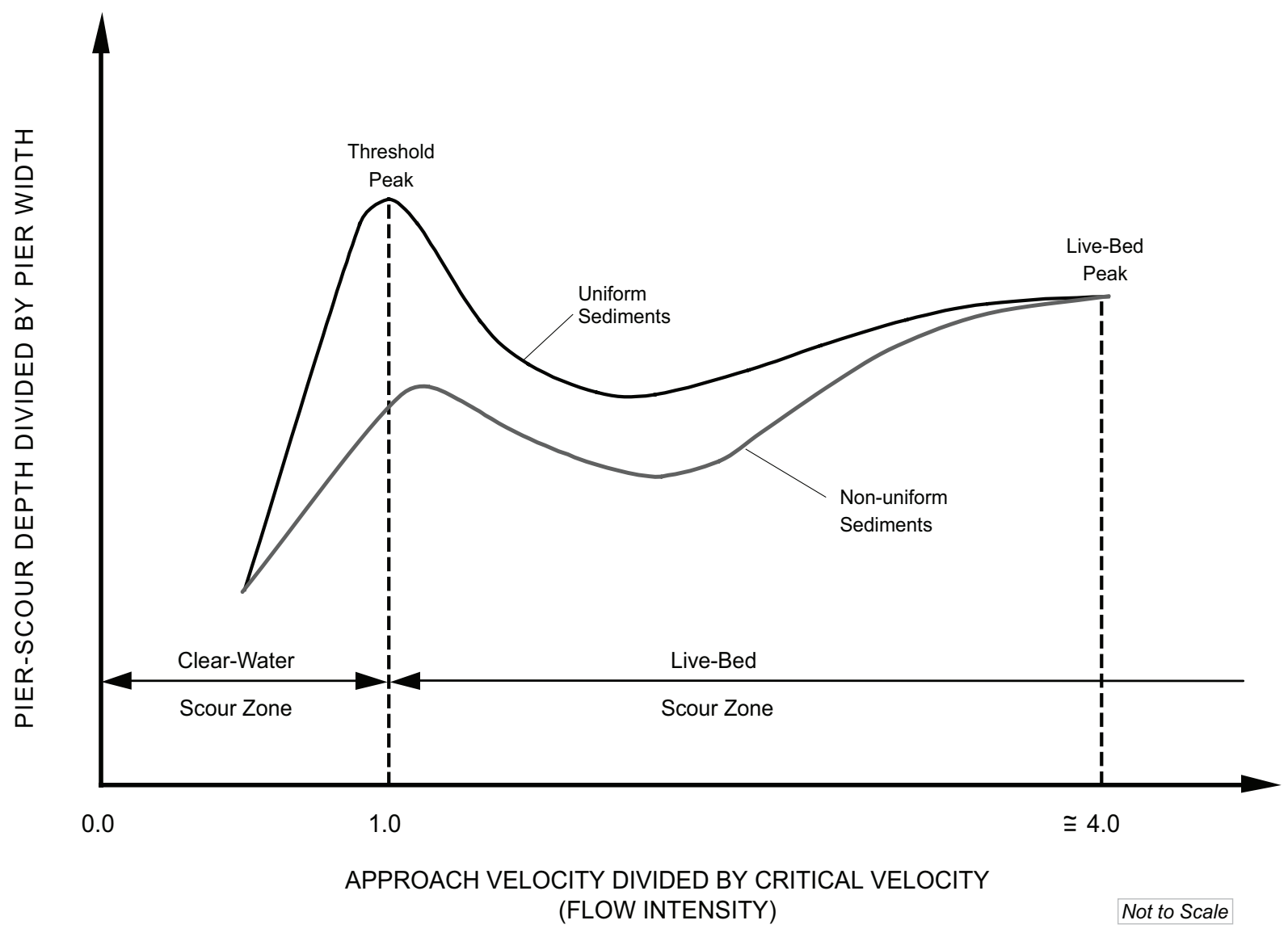

Figure 27. Generalized relation of flow intensity and relative pier scour based on laboratory investigations (modified from Breusers and Raudkivi, 1991). 
For non-uniform sediments, the threshold peak will be smaller than that for uniform sediments and will occur at a flow intensity greater than 1 (fig. 27). These variations are caused by the armoring of the scour-hole bed. Scour in non-uniform sediments initially erodes the smaller grain sizes leaving the larger grain sizes to armor the bed and thus reduce scour depth associated with the threshold peak. As velocity increases, the armored layer in the scour hole is eventually removed, allowing scour to resume and eventually reach the live-bed peak. The live-bed peaks for uniform and nonuniform sediments will be similar in magnitude and occur near the same flow intensity. The degree to which pier scour in a non-uniform sediment deviates from the curve for uniform sediment is dependent on the sediment gradation. A common indicator of the sediment gradation is the geometric standard deviation of the grain-size distribution. An equation from Yang (1996) computes this value:

$$
\sigma_{g}=\sqrt{\frac{D_{84.1} / D_{15.9}}{}}
$$

where

$\sigma_{g} \quad$ is the geometric standard deviation of the grain-size distribution (this will be called the sediment gradation for the remainder of the report);

$$
\begin{aligned}
& D_{84.1} \quad \text { is the grain size (in millimeters) for which } \\
& 84.1 \text { percent of the grain-size distribution } \\
& \text { is finer; and } \\
& D_{15.9} \quad \begin{array}{l}
\text { is the grain size (in millimeters) for which } \\
15.9 \text { percent of the grain-size distribution } \\
\text { is finer. }
\end{array}
\end{aligned}
$$

If the sediment gradation is approximately 1.3 or smaller, the sediment is considered uniform (Melville and Coleman, 2000), and pier-scour depth will develop similar to that of a uniform sediment (fig. 27). As the sediment gradation increases beyond 1.3, the threshold peak will diminish, and the flow intensity at which the threshold peak occurs will increase. While sediments with gradations greater than 1.3 are non-uniform, Breusers and Raudkivi (1991) note that for a sediment gradation of 2.0 or less, scour patterns closely follow those of a uniform sediment.

The distribution of the sediment gradation for the streams in this investigation indicate that all streams have non-uniform sediments (fig. 28). Approximately 70 percent of the sites have sediment gradations of about 2 or less, indicating that pierscour processes at a large percentage of the South Carolina sites will be similar to those of a uniform sediment. Because the maximum live-bed scour depth for uniform sediments is not strongly influenced by velocity, it is reasonable to anticipate that velocity associated with peak flows will have a minor influence on the live-bed pier-scour depths in South Carolina.

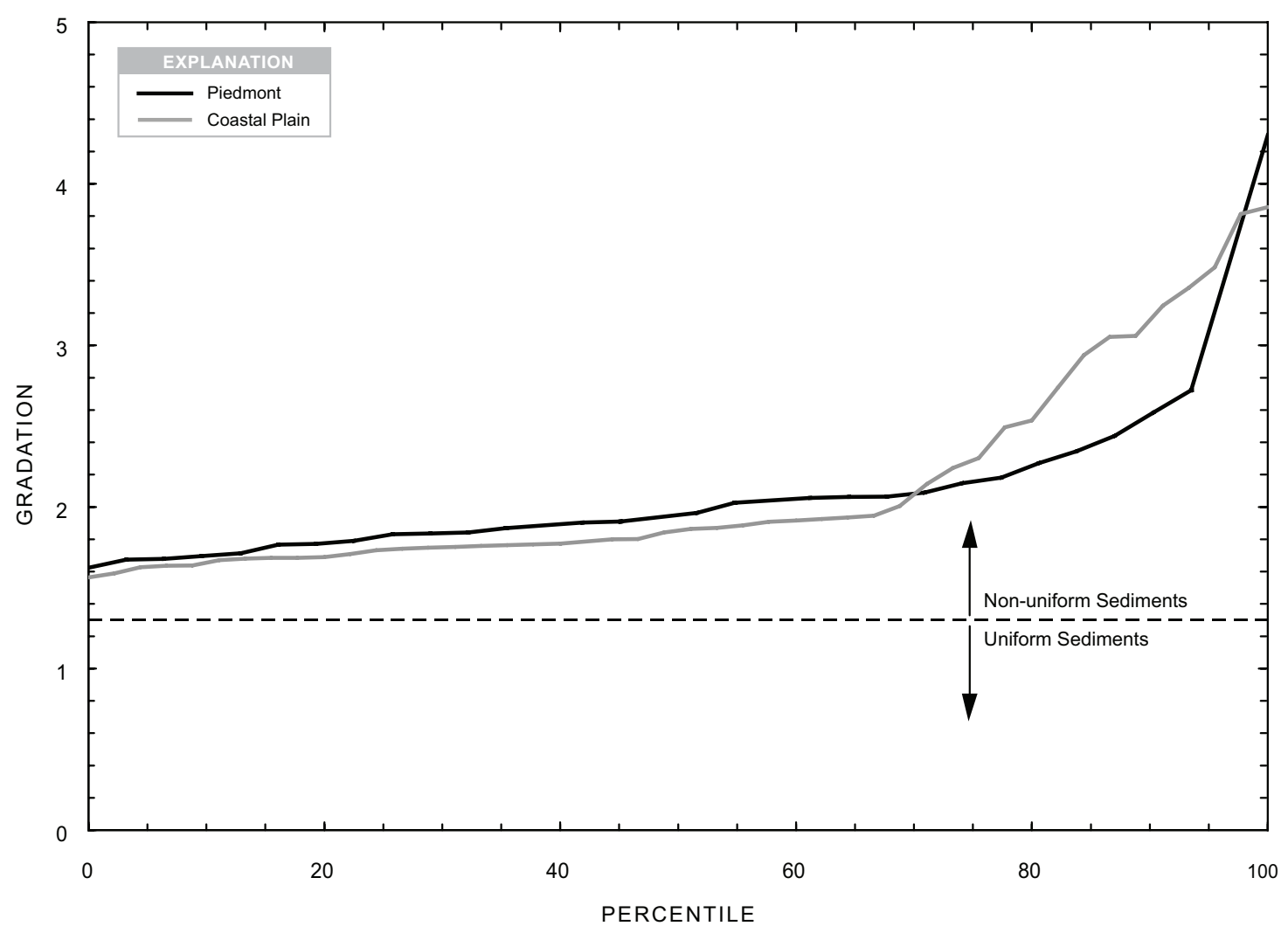

Figure 28. Distribution of sediment gradation for selected bridges in the Coastal Plain and Piedmont Physiographic Provinces of South Carolina. 
The relation of flow velocity to equilibrium live-bed pier-scour depth for selected laboratory data was taken from Yanmaz and Cicekdag (2001; fig. 29). The data were grouped by selected pier widths of $0.17,0.33$, and $0.5 \mathrm{ft}$, and logarithmic trend lines were drawn through each group of data. (Note: The trend lines in figure 29 were projected beyond the limits of the data to provide perspective on possible trends for larger flow velocities.) The significant scatter around each trend line can be attributed in part to the varying sediment sizes associated with the data. However, the data and trend lines clearly indicate that as flow velocity increases, its influence on scour depth diminishes, and above a flow velocity of approximately $2 \mathrm{ft} / \mathrm{s}$, its influence is relatively small. While the scale of the laboratory data differs from that of the field, it is reasonable to assume that it captures the general trends that should be anticipated in the field.

Figure 30 shows the relation of measured live-bed pier-scour depth to the flow velocity approaching the pier for selected data from the Coastal Plain (fig. 30A) and Piedmont (fig. $30 B$ ) of South Carolina. Because pier width is a strong explanatory variable, selected data were grouped by pier width. Additionally, because a larger number of pier-scour measurements occurred in the pier-width groups for 0.8 to $1.5 \mathrm{ft}$ and $4 \mathrm{ft}$, these data were selected to represent the trends for each region. (Note: The number of live-bed pier-scour measurements in the Piedmont is significantly less than those of the Coastal Plain, and the trends in the Piedmont data may not be as reliable as those for the Coastal Plain. The trends for both regions are similar, however, indicating that the trends in the Piedmont are reasonable.) The trend lines through the data indicate that the influence of approach flow velocity on live-bed pier-scour depth is weak, with only a slight increase in scour depth with increasing velocity. Most of the field data have approach-flow velocities that are $2 \mathrm{ft} / \mathrm{s}$ or greater, and the trends of the field data are consistent with that of the laboratory where the influence of approach-flow velocity on pierscour depth is relatively weak at a value greater than $2 \mathrm{ft} / \mathrm{s}$. A comparison of the slopes for the laboratory trend lines for velocities greater than $2 \mathrm{ft} / \mathrm{s}$ [approximately $0.051 \mathrm{ft} /(\mathrm{ft} / \mathrm{s})$ ] with those of the field data [average slope is $0.047 \mathrm{ft} /(\mathrm{ft} / \mathrm{s})$ ] indicates that these slopes are similar, further indicating that the qualitative trends of the field data are consistent with the those of the laboratory data.

The similarity of qualitative trends for the laboratory and field data indicates that the South Carolina field data are capturing the general trends for live-bed pier scour. The comparison also indicates that approach-flow velocity should have minimal influence on equilibrium live-bed pier-scour depths for the typical range of peak-flow velocities in South Carolina. Therefore, excluding the approach-flow velocity in the development of live-bed pier-scour envelope curves is appropriate.

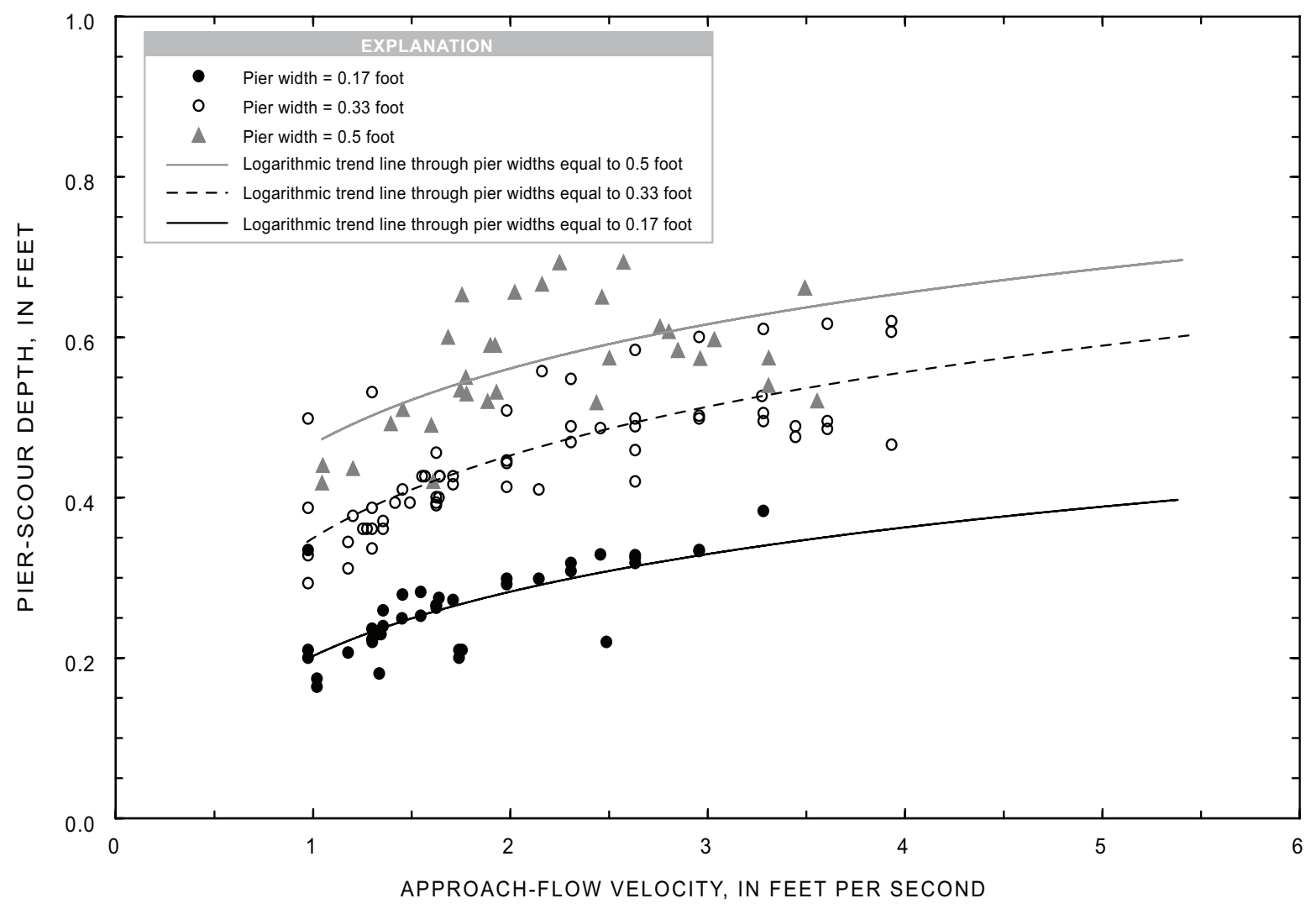

Figure 29. Relation of measured live-bed pier-scour depth and approach-flow velocity for laboratory data (Yanmaz and Cicekdag, 2001). 


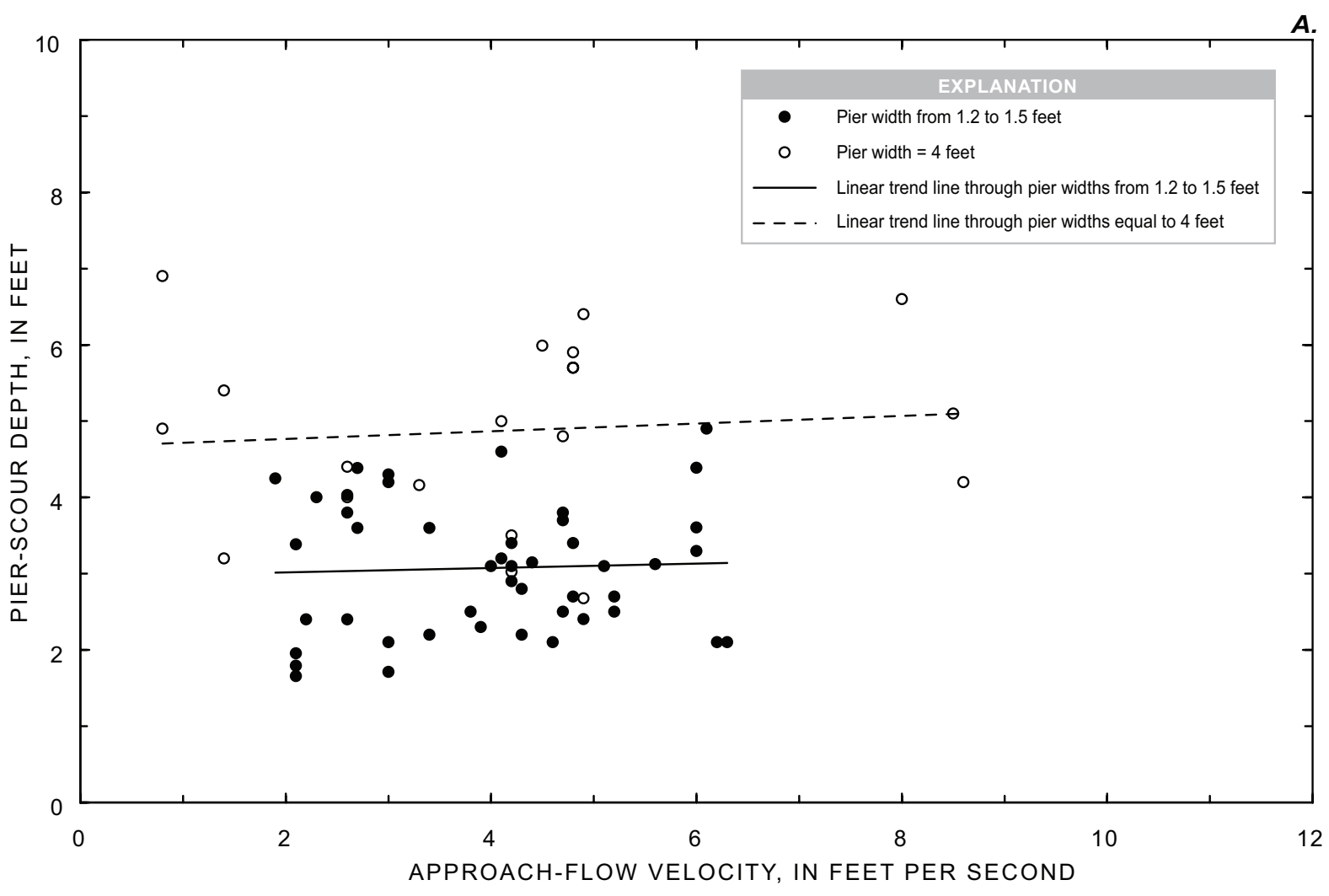

B.

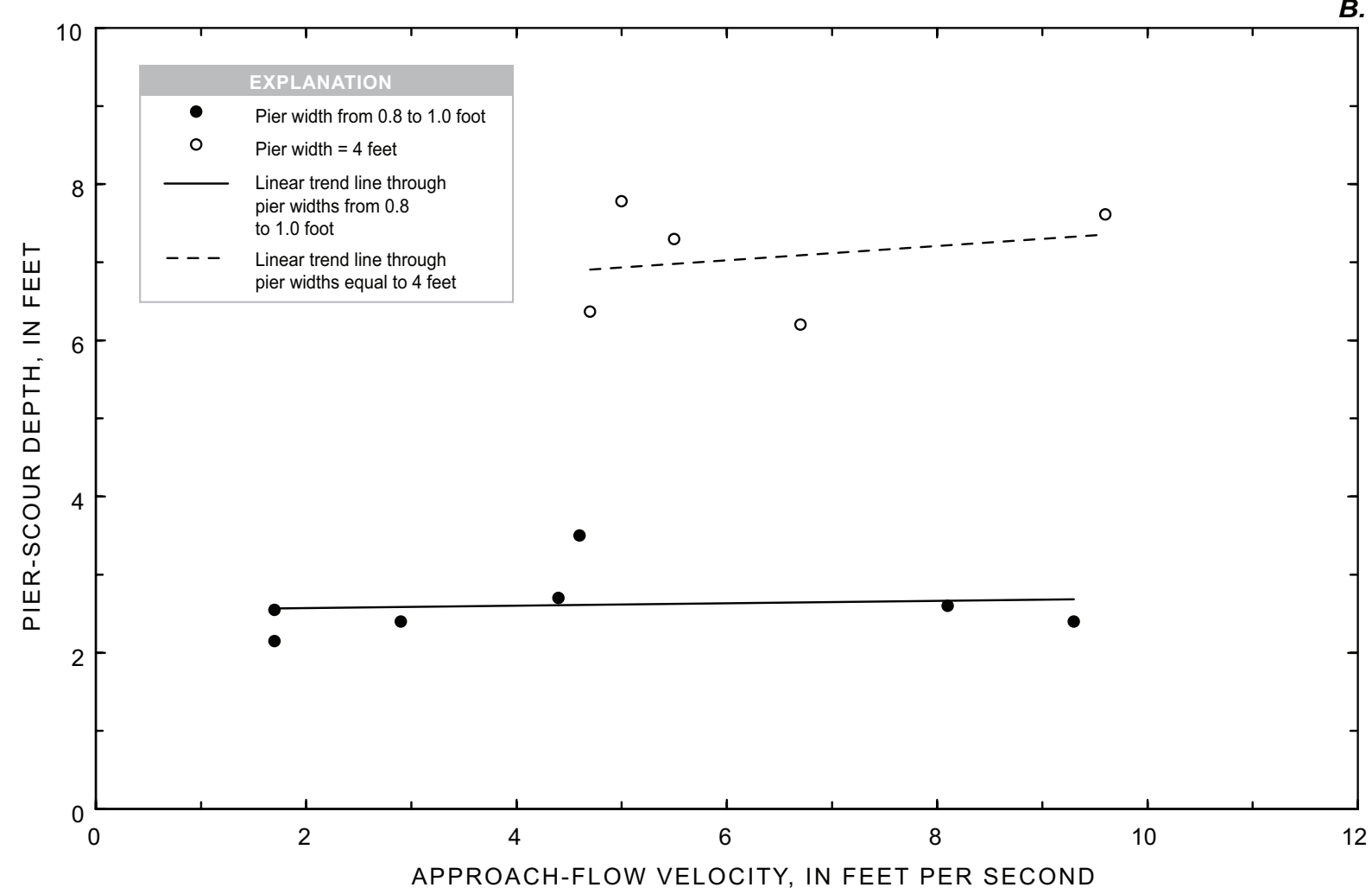

Figure 30. Relation of measured live-bed pier-scour depth and the approach-flow velocity for historic peak flows at selected sites in the (A) Coastal Plain Physiographic Province and (B) Piedmont Physiographic Province of South Carolina. 


\section{Flow Depth}

Results of laboratory investigations indicate that equilibrium live-bed pier-scour depths asymptotically increase with increasing approach-flow depth (Breusers and Raudkivi, 1991; Melville and Coleman, 2000). The relation between live-bed pier-scour depth and approach-flow depth for selected laboratory data (Yanmaz and Cicekdag, 2001) is shown in figure 31. The data are associated with the same laboratory measurements shown in figure 29 and are grouped by pier width in the same manner. Based on the description of laboratory trends from Breusers and Raudkivi (1991) and Melville and Coleman (2000), it is appropriate to use a logarithmic trend line to capture the data trends in figure 31. (Note: The trend lines in figure 31 were projected beyond the limits of the data to provide perspective on possible trends for larger flow depths.) As with figure 29, the significant scatter around the trend lines is likely caused, in part, by variation in sediment size. While the range of the flow depths for the laboratory data is small, the data and trend lines indicate that as flow depth increases, its influence on equilibrium pier-scour depth diminishes. Based on these trends, researchers have concluded that there is a unique flow depth relative to pier width beyond which pier-scour depth becomes independent of flow depth. Breusers and Raudkivi (1991) conclude that equilibrium pier-scour depth becomes independent of flow depth when the relative flow depth (flow depth divided by pier width) exceeds a dimensionless value of approximately 2 to 3 . Melville and Coleman (2000) recommend a relative flow depth of 1.5 .

The relation of live-bed pier-scour depth to the historic flow depth approaching the pier is shown for selected data from the Coastal Plain (fig. 32A) and Piedmont (fig. 32B) of South Carolina. The data are the same as those in figure 30 and are grouped by pier width in the same manner. The trend lines through the data indicate that the influence of approachflow depth on live-bed pier-scour depth is weak, with the Coastal Plain data showing a slight increase in scour depth with increasing flow depth and the Piedmont data showing a slight decrease. These trends are similar to the general laboratory trends (fig. 31) where the influence of flow depth on scour depth is small for larger flow depths. A comparison of the slopes for the laboratory trend lines (fig. 31) for flow depths greater than $1 \mathrm{ft}$ (average slope is $0.03 \mathrm{ft} / \mathrm{ft}$ ) with those of the field data in figure 32 (average slope is $0.01 \mathrm{ft} / \mathrm{ft}$ ) shows that these slopes are similar, further indicating that the field data display qualitative trends similar to the laboratory data. The South Carolina live-bed pier-scour measurements have relative flow depths (flow depth divided by pier width) that range from 1.9 to 26.3 with a median value of 6.4. These values of relative flow depth, in general, exceed the threshold values recommended by Breusers and Raudkivi (1991) and Melville and Coleman (2000), at which equilibrium pier-scour depth becomes independent of flow depth, giving justification for why the South Carolina live-bed pier-scour data is largely independent of flow depth.

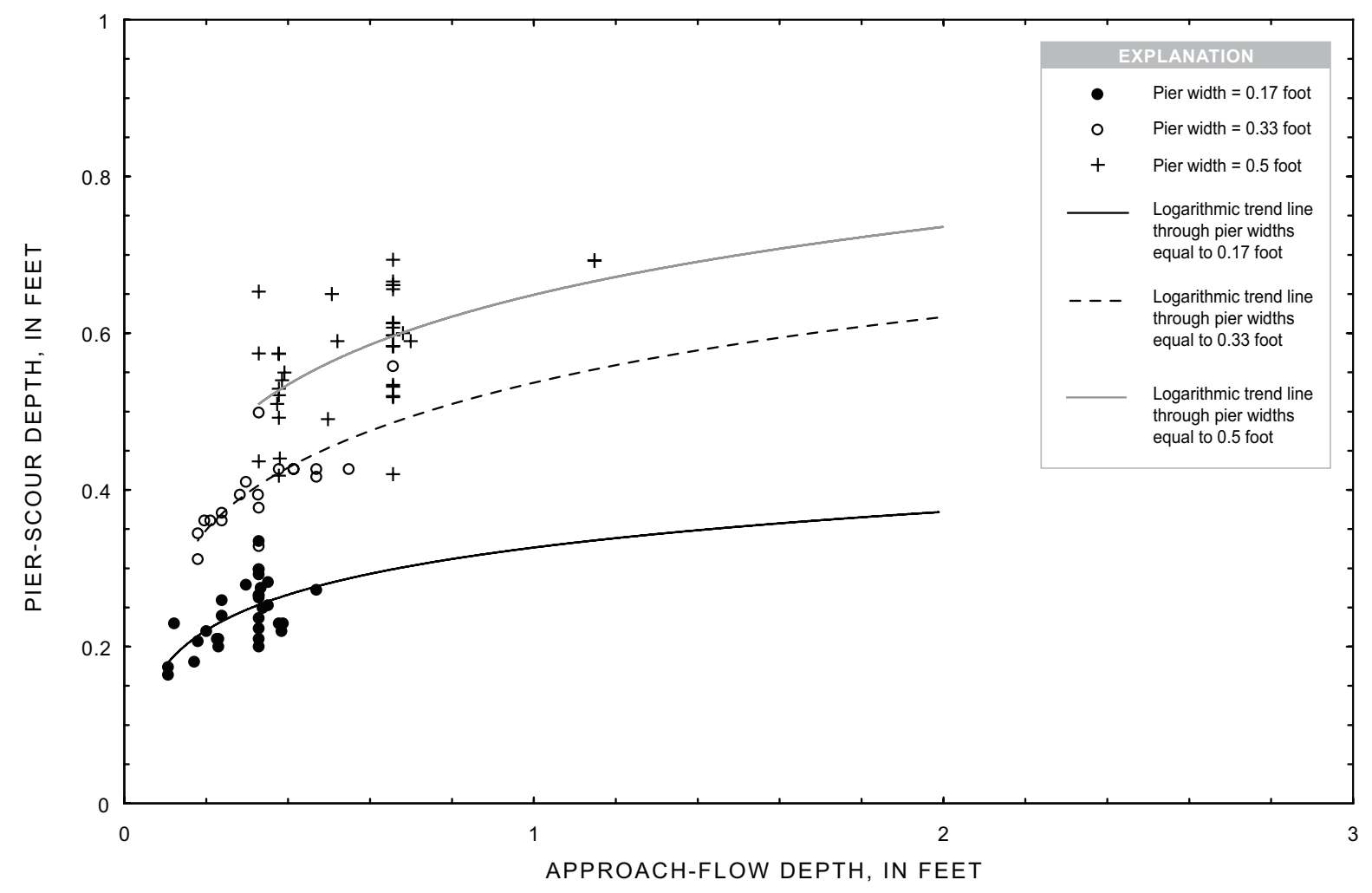

Figure 31. Relation of measured live-bed pier-scour depth and approach-flow depth for laboratory data (Yanmaz and Cicekdag, 2001). 

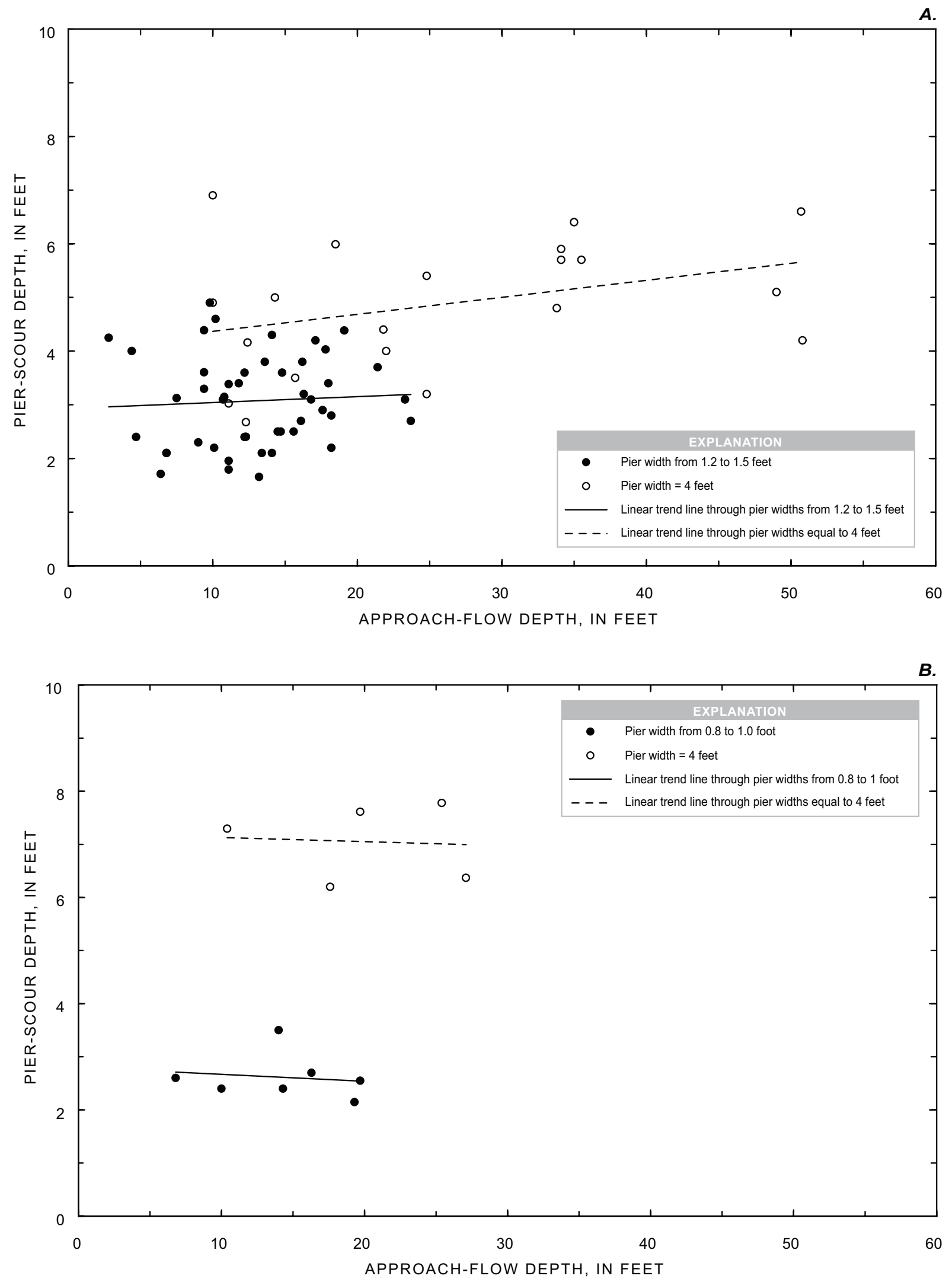

Figure 32. Relation of measured live-bed pier-scour depth and the approach-flow depth for historic peak flows at selected sites in the $(A)$ Coastal Plain and (B) Piedmont Physiographic Provinces of South Carolina. 
As noted previously, the similarity of trends for the laboratory and field data in figures 31 and 32 indicates that the South Carolina field data are capturing the general trends for live-bed pier scour. The comparison also indicates that approach-flow depth will have minimal influence on equilibrium live-bed pier-scour depths for the typical range of peak-flow depths in South Carolina. Therefore, excluding the approach-flow depth in the development of live-bed pier-scour envelope curves is appropriate.

\section{Sediment Size}

A typical laboratory relation from Melville and Coleman (2000) shows the general influence of sediment coarseness on equilibrium-scour depths for uniform sediments (fig. 33). The shape of this curve is similar for non-uniform sediments, with the maximum scour being lower because of the effect of armoring. The vertical axis in figure 33 represents the relative scour, and the horizontal axis represents the inverse of the relative grain size. Relative grain size is defined as the ratio of the median grain size $\left(D_{50}\right)$ to the pier width $(b)$. Figure 33 indicates that when the dimensionless ratio of $b / D_{50}$ is less than about 50, the grain size is relatively coarse, and pierscour depths will be diminished. In contrast, when $b / D_{50}$ is about 50 or greater, the grain size is relatively fine, and the potential for scour is at a maximum. Figure 33 also indicates that when $b / D_{50}$ is 50 or greater, the relative scour remains constant, and variation in grain size (within the relatively finesediment range) has no influence on equilibrium-scour depths. These two trends have important implications for understanding the effect of sediment size on live-bed pier scour in South Carolina. Because sediment sizes in South Carolina are typically fine, the potential for scour (with respect to the influence of sediment size) is at its maximum and is relatively constant even when sediment size varies. Sediment size is concluded to be a weak explanatory variable for live-bed pier scour in South Carolina and can be excluded when developing relations or envelope curves that help explain pier-scour trends because the potential for scour in relatively fine sediments is constant regardless of grain size.

Although river sediments in South Carolina are not uniform, they frequently have sediment gradations of 2 or less (fig. 28) and therefore will function, with respect to pier scour, similarly to a uniform sediment (Breusers and Raudkivi, 1991). The dimensionless variable $b / D_{50}$ can provide some insight into the effect of sediment size on pier-scour depths in South Carolina. For the 151 measurements of pier scour in this study, $D_{50}$ ranges from 0.24 to $1.7 \mathrm{~mm}$, pier widths range from 0.8 to $9 \mathrm{ft}$, and the dimensionless variable $b / D_{50}$ ranges from 179 to 3,810 . The upper limit of $b / D_{50}$ greatly exceeds 50 ,

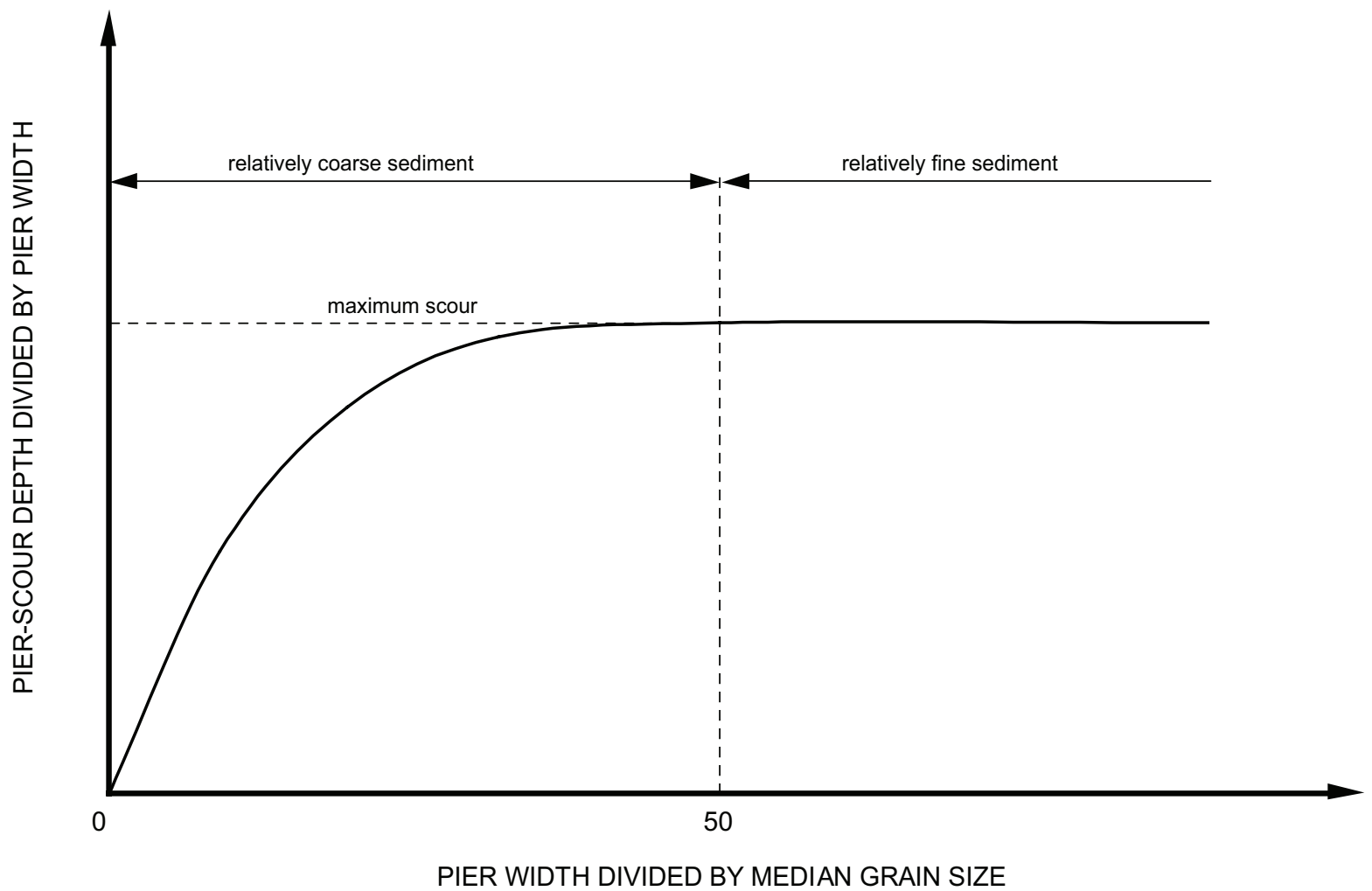

Not to Scale

Figure 33. General relation of relative sediment size to relative pier scour based on laboratory investigations (from Melville and Coleman, 2000). 
indicating that river sediments in South Carolina are relatively fine; therefore, conditions promote the maximum potential for scour. Additionally, because the potential for scour in relatively fine sediments is constant (see relatively fine sediment range in figure 33) and does not vary as grain size varies, it is appropriate to assume that sediment size will not be a strong explanatory variable for pier scour in South Carolina. Therefore, grain size can be excluded when developing relations or envelope curves that help explain live-bed pier scour in South Carolina.

The relation between live-bed pier-scour depth and median sediment size for selected laboratory data (Yanmaz and Cicekdag, 2001) is shown in figure 34. The data are associated with the same laboratory measurements shown in figure 29 and are grouped by pier width in the same manner. As with figure 29, significant scatter around the trend lines is caused, in part, by variation in flow depth and flow velocity. For pier widths of 0.17 and $0.33 \mathrm{ft}$ and median sediment sizes of $0.7 \mathrm{~mm}$ and less, the general trend is for the upper bound of pier-scour depth to slightly decrease with increasing median sediment size. For median sediment sizes greater than $0.7 \mathrm{~mm}$, the limited data suggest that scour depths slightly increase with increasing sediment size. This pattern likely is caused by the transition from ripple- to non-ripple-forming sediments. Ripple-forming sediments are sands with grain sizes approximately $0.7 \mathrm{~mm}$ or less that form ripples on the channel bed. In contrast, non-ripple-forming sediments have grain sizes larger than approximately $0.7 \mathrm{~mm}$ and form relatively flat channel beds. Laboratory investigations have shown that ripples tend to limit scour from developing to the same depth as that for a flat bed (Breusers and Raudkivi, 1991; Melville and Coleman, 2000). The transition from decreasing to increasing scour for pier widths equal to $0.33 \mathrm{ft}$ occurs at the approximate breakpoint for ripple and non-ripple sediments $(0.7 \mathrm{~mm})$ giving some explanation for the trends in figure 34 . Regardless of these patterns associated with ripple and nonripple sediments, the trend lines through the data are relatively flat, indicating that sediment size has minimal influence on equilibrium pier-scour depth.

Figure 35 shows the relation of live-bed pier-scour depth to the median grain size for selected data from the Coastal Plain (fig. 35A) and Piedmont (fig. 35B) of South Carolina. The data are the same as those in figure 30 and are grouped by pier width in the same manner. While there is significant scatter in the data, the flat trend lines indicate that the influence of median sediment size on live-bed pier-scour depth is weak, which is consistent with the trends in the laboratory data (fig. 34). It is interesting to note that the Coastal Plain data for pier widths equal to $4 \mathrm{ft}$ (fig. $35 \mathrm{~A}$ ) have a similar trend to the laboratory data for pier widths equal to $0.33 \mathrm{ft}$ (fig. 34).

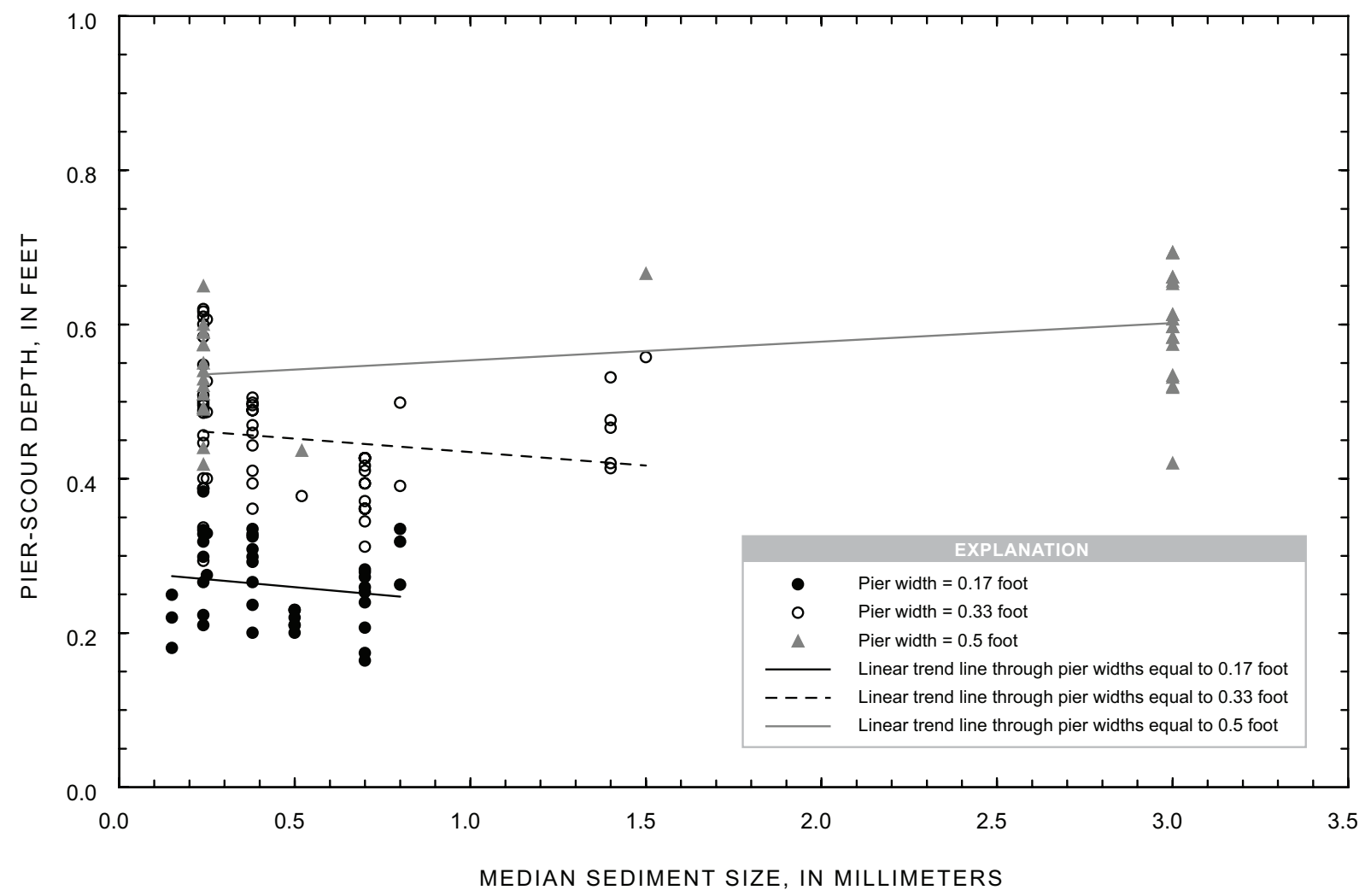

Figure 34. Relation of measured live-bed pier-scour depth and median sediment size for laboratory data (Yanmaz and Cicekdag, 2001). 
A.

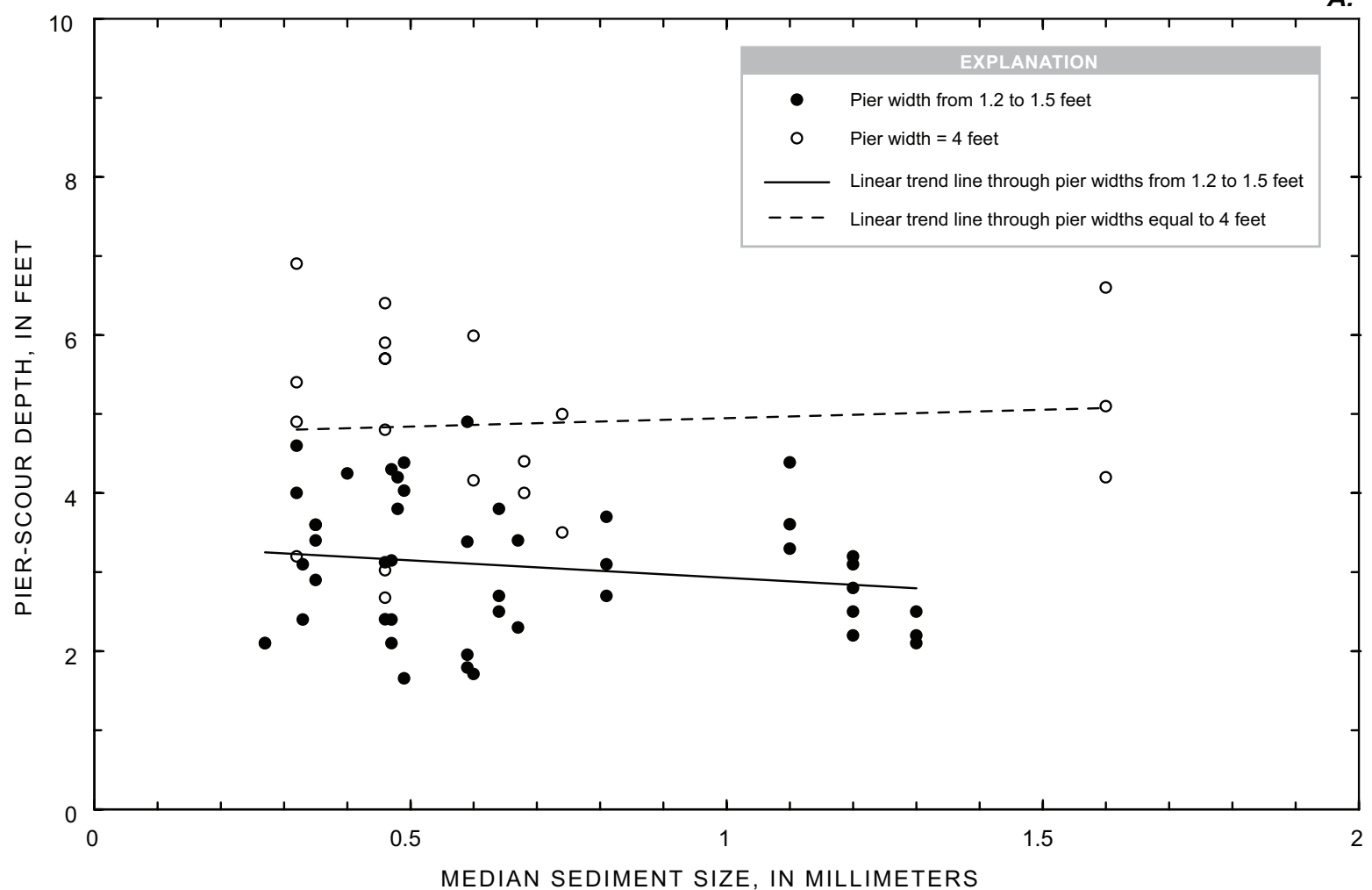

B.

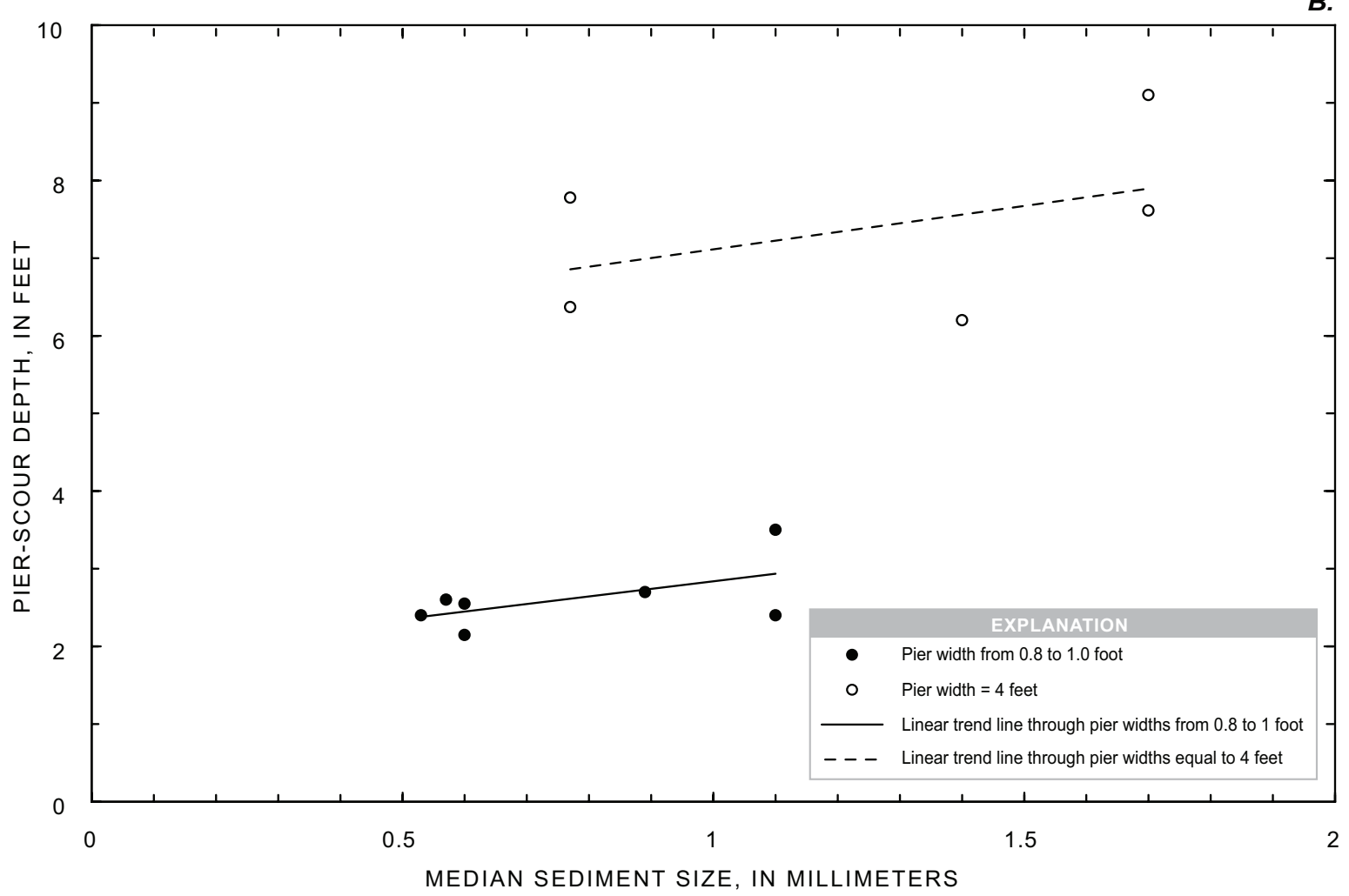

Figure 35. Relation of measured live-bed pier-scour depth and the median sediment size at selected sites in the $(A)$ Coastal Plain and $(B)$ Piedmont Physiographic Provinces of South Carolina. 
Scour depths generally decrease with increasing median sediment size up to about $0.7 \mathrm{~mm}$. The field data are sparse for larger grain sizes, but the limited data indicate an increase in scour depth for median sediment sizes greater than $0.7 \mathrm{~mm}$. Of further interest is the trend in the Piedmont data (fig. 35B). Sediment sizes for these data are predominantly greater than $0.7 \mathrm{~mm}$, which is the approximate grain size where scour depth in the laboratory data for pier widths of $0.33 \mathrm{ft}$ (fig. 34) begins to increase with increasing sediment size. The Piedmont data show a mild increase of scour depth with increasing sediment size, verifying the trend of the laboratory data.

The similarity of trends for the laboratory and field data in figures 34 and 35 indicates that the South Carolina field data are capturing the general trends for live-bed pier scour. The comparison also indicates that median sediment size will have minimal influence on equilibrium live-bed pier-scour depths for the typical range of median sediment sizes in South Carolina. Therefore, excluding the median sediment size in the development of live-bed pier-scour envelope curves is appropriate.

\section{Pier Shape}

Laboratory studies indicate that pier shape can influence scour depths; pier shapes that are more streamlined (round and sharp nosed) tend to create smaller scour depths than square-shaped piers. When the pier is uniform in shape in the vertical direction, which is common in South Carolina, Melville and Coleman (2000) note that the influence of shape is relatively insignificant, and a square-nosed pier produces a scour depth about 10 percent greater than that of a cylinder of the same width. To account for this phenomenon, the HEC-18 pier-scour equation (Richardson and Davis, 2001) includes a correction coefficient for shape: round piers have a coefficient of 1 , sharp-nosed piers have a coefficient of 0.9 , and square-nosed piers have a coefficient of 1.1. The influence of pier shape becomes negligible when pier skew is greater than 5 degrees, and a shape coefficient of 1 can be used under such circumstances (Melville and Coleman, 2000; Richardson and Davis, 2001). (Note: The laboratory data from Yanmaz and Cicekdag [2001] are for cylindrical piers, so they cannot be used to display the effects of pier shape on scour depths.)

The relation of live-bed pier-scour depth to pier width for the South Carolina field measurements with data grouped by square and round pier shape is shown in figure 36 . The squareshaped piers are largely associated with pier widths smaller than 2 feet, and the round-shaped piers are associated primarily with pier widths larger than 2 feet. The scatter in the data makes it difficult to draw strong conclusions about the effect of pier shape on scour depth; however, data for both roundand square-shaped piers are near the upper bound of the data, indicating that effect of pier shape is probably small. Mueller and Wagner (2005) made a similar conclusion with respect to field data from the NBSD, noting that "pier shape does not

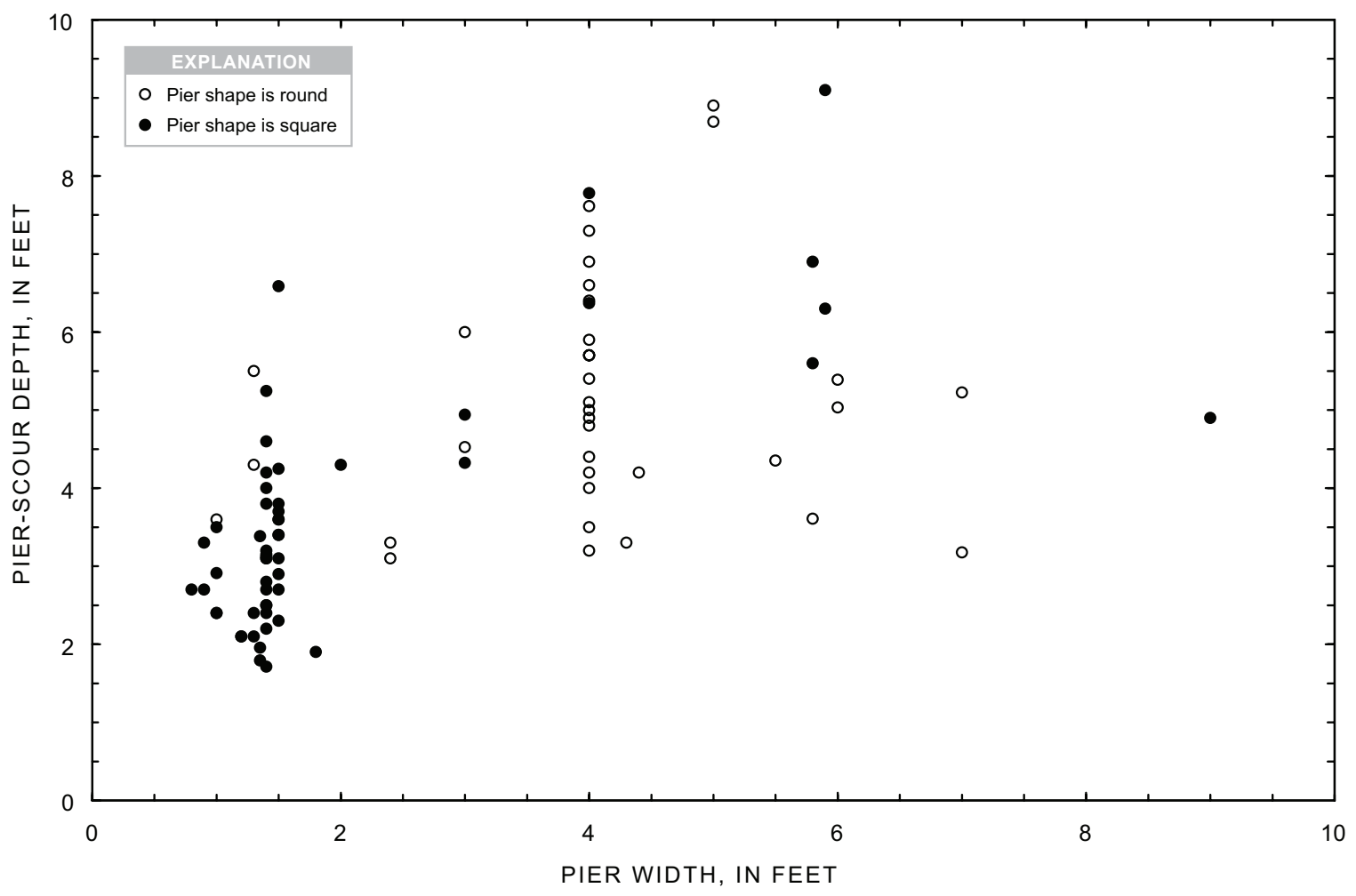

Figure 36. Relation of measured live-bed pier-scour depth and pier width grouped by pier shape for selected sites without pier skews in the Coastal Plain and Piedmont Physiographic Provinces of South Carolina. 
affect the depth of scour in the field as much as it does in the laboratory." Based on the trends of figure 36 and the observations of Mueller and Wagner (2005), it is reasonable to assume that pier shape does not have a large influence on live-bed pier-scour depths in South Carolina and can be excluded in the development of live-bed pier-scour envelope curves.

\section{Pier Skew}

Laboratory investigations indicate that alignment of the pier to flow (pier skew) can significantly influence scour depths; as the aspect ratio of pier length to pier width increases, the influence of pier skew also increases (Breusers and Raudkivi, 1991; Melville and Coleman, 2000). The influence of pier skew is attributed to the increase of the effective frontal width of the pier as the pier skew becomes larger. When the length-to-width aspect ratio is large, small changes in pier skew can significantly increase the effective frontal width of the pier, thus increasing pier-scour depth. The laboratory data indicate that with large skews and aspect ratios, pier-scour depths can be as much as 6 times those of unskewed piers. In the case of a cylinder, the aspect ratio is 1 , and pier skew has no effect.

Multiple-column piers and pile bents (figs. 13, 14, 15, and 18) are common bridge supports in South Carolina, and evaluating the influence of pier skew at such supports is more complicated than evaluating the influence of a single uniform pier. A typical column in a multiple-column pier or a pile in a pile bent has a length-to-width aspect ratio near 1; therefore, the effect of pier skew on an individual column or pile is small. However, when columns or piles are aligned near one another, the surrounding columns or piles potentially influence scour depths. This influence diminishes as the spacing between the columns and piles increases. If the spacing is relatively close, the interaction between columns and piles can be strong, and scour depth increases with increasing pier skew. Using laboratory data, Melville and Coleman (2000) tabulated pier-skew correction coefficients for pile bents (table 2) with selected pile spacing (measured from center-to-center of piles) and skews. (Note: Table 2 is applicable to pile bents and multiple-column piers.) At a pile-spacing to pile-width ratio of 10 , there is no influence from the surrounding piles. As this ratio diminishes, the influence from surrounding piles

Table 2. Pier-skew correction coefficients for pile bents (from Melville and Coleman, 2000).

[Applicable to pile bents and multi-column piers]

\begin{tabular}{|cccc}
\hline $\begin{array}{c}\text { Pile-spacing to } \\
\text { pile-width ratio }\end{array}$ & $\begin{array}{c}\text { Pier skew } \\
\text { less than } \\
\text { 5 degrees }\end{array}$ & $\begin{array}{c}\text { Pier skew } \\
\text { between } \\
\text { 5 and } \mathbf{4 5} \text { degrees }\end{array}$ & $\begin{array}{c}\text { Pier skew } \\
\text { equal to } \\
\text { 90 degrees }\end{array}$ \\
\hline 2 & 1.12 & 1.40 & 1.20 \\
4 & 1.12 & 1.20 & 1.10 \\
6 & 1.07 & 1.16 & 1.08 \\
8 & 1.04 & 1.12 & 1.02 \\
10 & 1.00 & 1.00 & 1.00 \\
\hline
\end{tabular}

increases, and the effect of pier skew is stronger. However, the influence of pier skew on a pile bent is always smaller (and often significantly smaller) than on a comparable solid pier. To account for this diminished scour depth at skewed pile bents, HEC-18 (Richardson and Davis, 2001) recommends that if piles or multiple columns are spaced 5 pier widths or greater apart (center-to-center), the pier-skew correction coefficient should be limited to 1.2 times the local scour of a single column. For spacings less than 5 pier widths, the standard skewcorrection coefficient is to be applied. This method would be more conservative than using the coefficients in table 2 .

In the current study, 120 of the 151 pier-scour measurements are associated with pile bents or multiple-column bents, with column spacings ranging from 3.1 to 35 pier widths. The five measurements having column spacings less than 5 pier widths are associated with bridge widening, where new piles were driven near the old structure supports (figs. 18 and 19), thus giving relatively small spacings between some of the columns. Typical pile bents or multiple-column piers in South Carolina that are not associated with a bridge widening (figs. 13, 14, and 15), have spacings between the piles or columns that are approximately 5 pier widths or greater, indicating that the effect of skew at such sites will be limited and that the maximum pier-skew correction coefficient should not exceed 1.2.

Of the 151 measurements of pier scour in this investigation, 100 have no pier skew; the remaining 51 measurements have pier skews ranging from 5 to 30 degrees with an average of 17 degrees. Of these 51 pier-scour measurements, 41 have pier skews associated with pile bents or multiple-column bents where the effect of skew is significantly diminished from that of a comparable solid pier. In addition, the selection of the pier-skew values has a measure of subjectivity, and the selected pier-skew angles likely have some error associated with them. These data limitations in the South Carolina database must be kept in mind when attempting to evaluate the effect of pier skew within the South Carolina data.

To provide some perspective on the relation of pierscour depth and the effect of pier skew in the South Carolina field data, the relation of pier-scour depth and pier width for data with and without pier skew was examined (fig. 37). For multiple-column piers (including pile bents), the skew angles range from 5 to 30 degrees with a median of 10 degrees. The range and scatter of the skewed multiple-column piers are similar to that of the non-skewed data, indicating that influence of skew at multiple-column bents is fairly small. Based on this trend, it is probably appropriate to combine scour measurements at skewed multiple-column piers and pile bents with the non-skewed data in the South Carolina database when developing upper-bound envelope curves for live-bed pier scour. For skewed single piers, the skew angles range from 5 to 30 degrees with a median of 25 degrees. The upper bound of the data at these piers exceeds that of the non-skewed data, indicating that the influence of skew at single-column piers can be significant. The skewed piers with scour depths exceeding the range of the scour depths of piers with no skew 


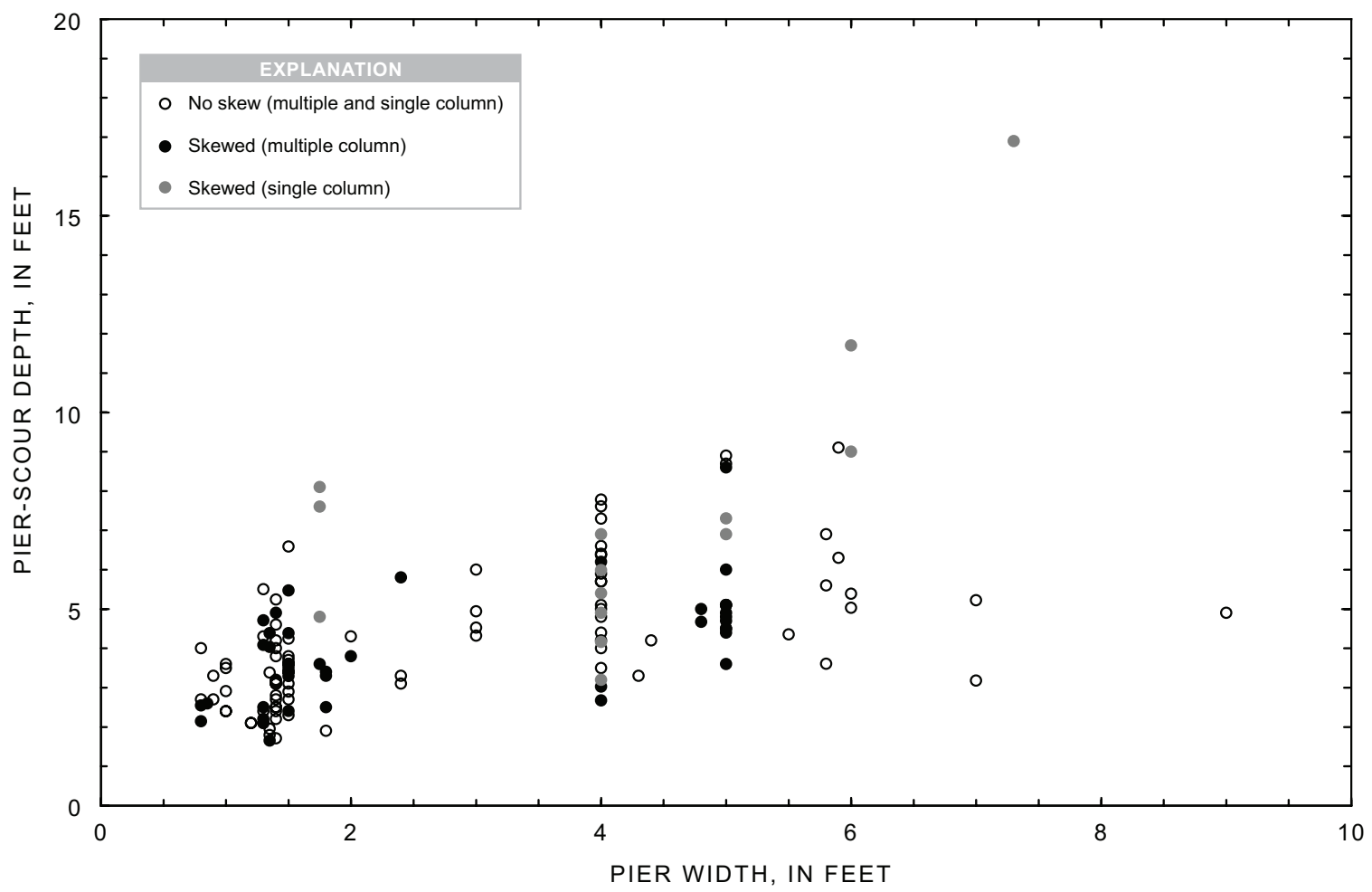

Figure 37. Relation of measured live-bed pier-scour depth, with and without pier skews, and pier width for selected sites in the Coastal Plain and Piedmont Physiographic Provinces of South Carolina.

are associated with long, solid piers with large aspect ratios, showing that the influence of skew is more significant at these piers. The larger influence of skew at such piers indicates that measurements at these types of skewed piers should be excluded from the development of the live-bed pier-scour envelope curves.

\section{Pier Width and the South Carolina Live-Bed Pier-Scour Envelope Curve}

Researchers agree that pier-scour depth is strongly related to pier width. According to Richardson and Davis (2001), "Pier width has a direct influence on depth of local scour. As pier width increases, there is an increase in scour depth." Melville and Coleman (2000) reported, “...the depth of scour at a pier is strongly dependent on the width of the pier." After analyzing 224 field measurements of pier scour from the NBSD, Mueller (1996) concluded, “...pier width shows the strongest correlation with pier scour." Although other variables, such as flow velocity, flow depth, sediment size, flow alignment, and pier shape, influence pier-scour depth, the previous analysis indicates that these influences often are small for field conditions in South Carolina. If, however, pier width is a strong explanatory variable for pier-scour depth, pier width can be used as the primary explanatory variable in the development of simple envelope curves that display the upper-bound trend of scour in South Carolina. Such envelope curves are simple but useful tools that can be used to evaluate the potential for scour, evaluate the reasonableness of predicted scour, and in general, help practitioners develop judgment regarding the range and trend of scour under given field conditions. The following section contains reviews of the upper bound relation of pier width to pier-scour depth in laboratory and field data and describes the development of the South Carolina live-bed pierscour envelope curve and its applications and limitations.

\section{Envelope Curves for Laboratory and Field Data}

The relation of pier-scour depth to pier width for laboratory data is shown in figure $38 \mathrm{~A}$. The relation includes data used to develop the original HEC-18 pier-scour equation (Richardson and others, 1991) and laboratory data from Yanmaz and Cicekdag (2001) and indicates that the upper bound of scour generally increases with increasing pier width. Figure $38 B$ shows the laboratory relation of pier width to relative scour (scour depth divided by pier width) and indicates that the upper bound of relative scour decreases with increasing pier width. (Note: The envelope curves in figure $38 B$ were projected beyond the limits of the upper-bound data to provide perspective on possible trends for larger pier widths.) The envelope curves in this plot were developed by dividing the envelope-curve equations in figure $38 \mathrm{~A}$ by pier width. The trends of the envelope curves for relative scour 

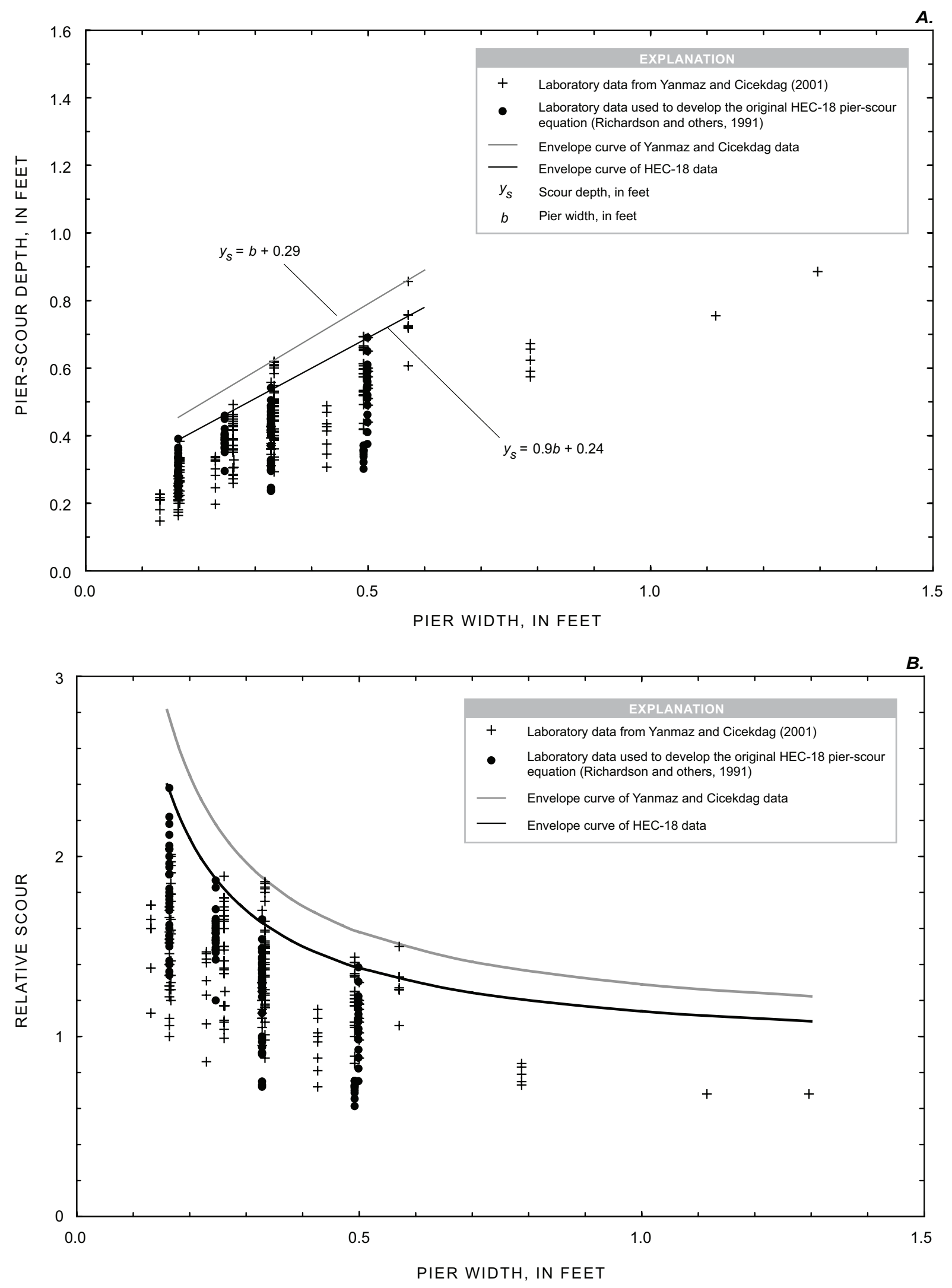

Figure 38. Relation of pier width to live-bed $(A)$ pier-scour depth and $(B)$ relative scour for selected laboratory data. 
(fig. 38B) indicate that as pier width increases, relative scour asymptotically approaches a constant. The envelope curves for the HEC-18 data and the Yanmaz and Cicekdag (2001) data have asymptotic limits for relative scour of 0.9 and 1.1 , respectively.

To provide perspective on how the trends of the South Carolina field data compare with the trends of the laboratory data, the laboratory and field data were plotted for analysis (fig. 39). The envelope curves of the laboratory data were extended to show how they compare with the envelope curve of the field data. (The extension of the laboratory envelope curves exceeds the range of the laboratory data by approximately 800 percent, and the excessive extrapolation would be considered inappropriate for many engineering applications. Although the extrapolated laboratory curves are useful in comparing with the field data, the excessive extrapolation highlights potential problems with scaling laboratory data to the field data.) The trends of the field data are similar to those of the laboratory data, having envelope curves with similar slopes and shapes, but a larger upper bound. The similarity in envelope curves indicates that the qualitative trend of the upper bound of the South Carolina data is reasonable; however, it is uncertain why the upper bound of the field data is approximately $3 \mathrm{ft}$ greater than the upper bound of the laboratory data. As noted previously (fig. 21), the South Carolina data may have some error associated with the GPR interpretation, and this, in part, may account for the larger upper bound. Additionally, the approach-flow velocities and depths associated with the field data are significantly larger than those of the laboratory data. For the South Carolina field data, the approach-flow velocities range from 0.8 to $9.6 \mathrm{ft} / \mathrm{s}$ with a median value of $4.7 \mathrm{ft} / \mathrm{s}$, while those for the laboratory data (Yanmaz and Cicekdag, 2001) range from 0.7 to $3.9 \mathrm{ft} / \mathrm{s}$ with a median value of $1.7 \mathrm{ft} / \mathrm{s}$. (Note: The approach-flow velocities for the South Carolina field data as noted here are based on the maximum historic flows as defined in the report section "Estimate of Maximum Historic Flows." These values are slightly different from the data presented in figure 5 which are based on the 100-year flow.) Flow depths for the South Carolina field data range from 2.8 to $50.8 \mathrm{ft}$ with a median value of $17 \mathrm{ft}$, while those for the laboratory data (Yanmaz and Cicekdag, 2001) range from 0.1 to $1.2 \mathrm{ft}$ with a median value of $0.3 \mathrm{ft}$. Although it has been noted that pier-scour depth is insensitive to flow velocity and depth, scour depth still mildly increases as these variables increase (figs. 29-32), and the large differences in these variables between the field and laboratory data may account, in part, for the larger upper bound of the field data. Finally, the laboratory data typically are associated with straight, rectangular, and un-contracted channels that minimize secondary flow patterns that potentially increase scour. In contrast, the field data are typically associated with meandering, non-uniform, and contracted channels that tend to produce secondary flow patterns that can increase scour potential and, therefore, increase the upper bound of scour.
To help assess the validity of the upper-bound trend for the South Carolina data, the South Carolina data were plotted along with selected live-bed data from the NBSD (fig. 40). (Note: The envelope curves for the laboratory data and South Carolina field data in figure 40 were projected beyond the limits of the data to allow comparison with the NBSD envelope curve.) The NBSD data include 92 measurements that were selected for their similarity to the South Carolina data, including measurements with no skew, insignificant influence from debris, and fine to medium sands. The NBSD data show a similar qualitative trend of increasing upper bound of scour with increasing pier width to that of the laboratory data and the South Carolina field data. This confirms that the general trend of the upper bound of the South Carolina data is reasonable. The majority of the selected NBSD data fall within, or are very close to, the South Carolina envelope curve. Three NBSD measurements significantly exceed the envelope curve. These three measurements are associated with large rivers having drainage areas that range from 52,300 to $60,700 \mathrm{mi}^{2}$, which is significantly greater than the basin sizes associated with the South Carolina data where the range is from 17.2 to $9,360 \mathrm{mi}^{2}$ and the median size is $252 \mathrm{mi}^{2}$ (fig. 4). As noted previously, live-bed pier-scour depth likely is relatively insensitive to flow duration and thus drainage area (see the report section on "Time and Flow Duration"); however, scour depth may increase mildly with increasing drainage area, and the significantly larger drainage areas associated with the three NBSD measurements of interest may provide some explanation for why they exceed the South Carolina data. Additionally, the larger drainage areas associated with the three NBSD data imply larger and more complex river channels that increase the potential for turbulence and secondary flow patterns which increase scour potential, giving some additional explanation of why they may exceed the South Carolina data. Based on these observations, it is probable that the upper bound of the South Carolina live-bed pier-scour data is reasonable for the range of field conditions (including drainage area) associated with that data and can be used to help understand live-bed pier-scour potential for sites having similar characteristics.

The upper-bound of the envelope curve of the South Carolina data may be considered questionable because the live-bed pier-scour data collected for this investigation cannot be directly associated with the flow conditions that created the scour. However, the data include estimates of the maximum historic flows at 61 of the 78 bridges, with 48 of these 61 bridges having had flows equaling or exceeding approximately 70 percent of the 100 -year flow magnitude (table 1 ). The South Carolina data and envelope curves for the 118 pierscour measurements from the 61 bridges with known maximum historic flows are shown in figure 41. The pier-scour data have been grouped into four categories: (1) data associated with maximum historic flows between 0.7 to 1.3 times the 100-year flow, (2) data associated with maximum historic flows greater than 1.3 times the 100-year flow, (3) data 

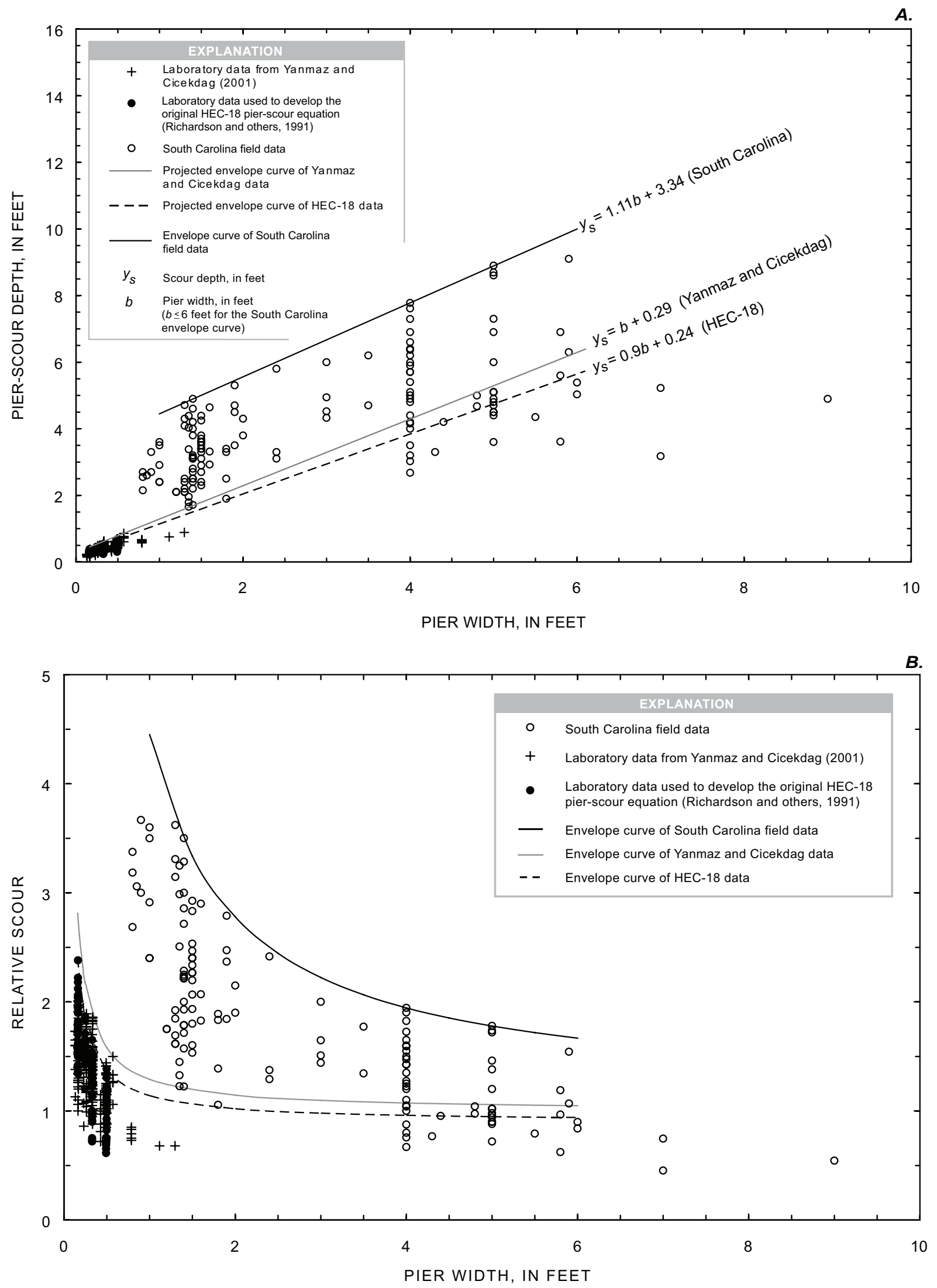

Figure 39. Relation of pier width to $(A)$ measured live-bed pier-scour depth, and $(B)$ relative scour for selected data from laboratory investigations and field data from selected sites in South Carolina. 


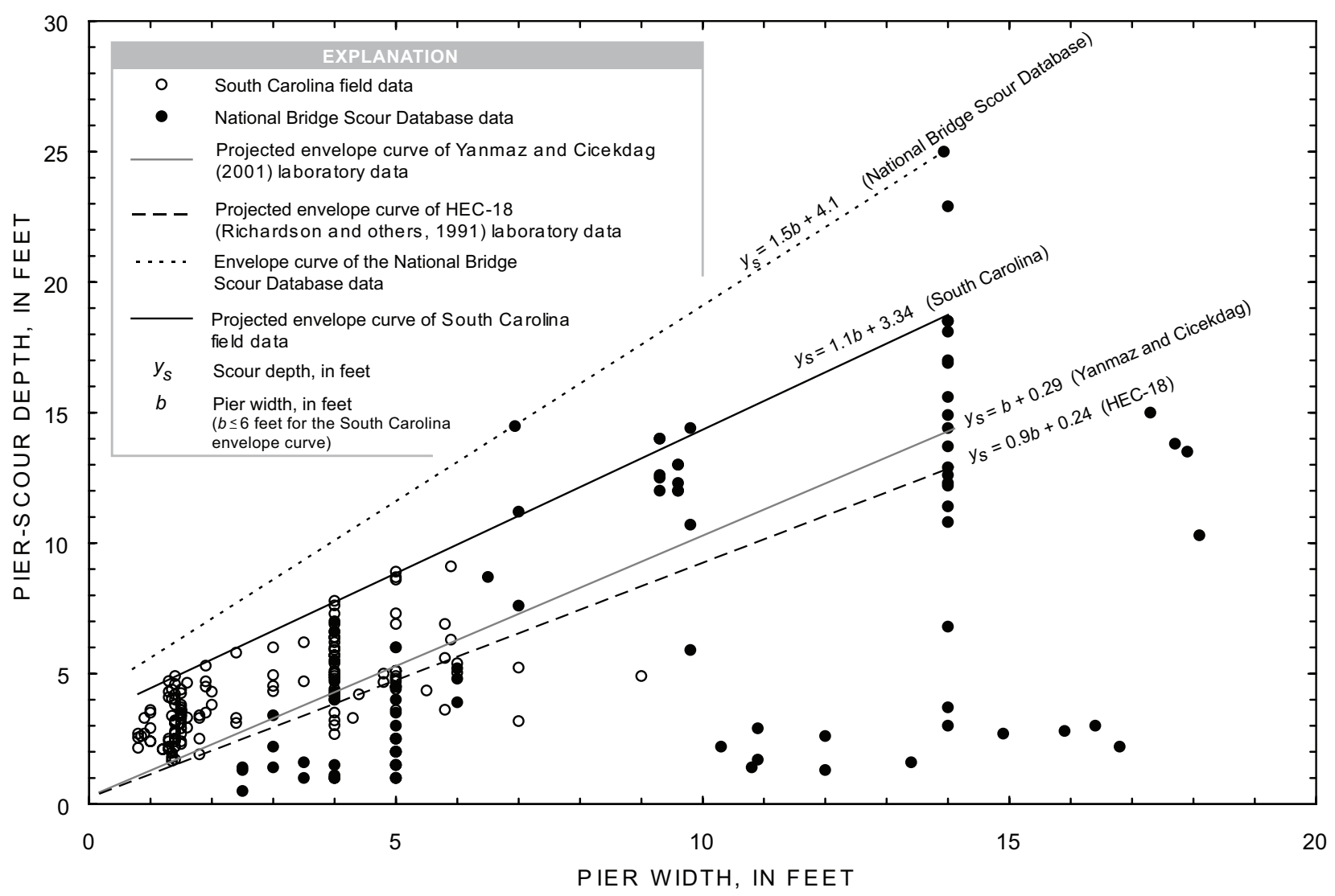

Figure 40. Relation of live-bed pier-scour depth and pier width for selected data from the National Bridge Scour Database and selected sites in South Carolina. Envelope curves for selected laboratory and field data also are shown.

associated with maximum historic flows less than 0.7 times the 100-year flow, and (4) data with unknown maximum historic flows. The trends in figure 41 show how the data associated with maximum historic flows near the 100-year flow magnitude ( 0.7 to 1.3 times the 100 -year flow) are the data that fit well within the envelope curve and define the upper bound of the data. This indicates that the South Carolina live-bed envelope curve reflects an upper bound of scour for flows near the 100-year flow magnitude and can be used to assess scour for such flow conditions.

The South Carolina pier-scour data and envelope curve were plotted for sites in the Coastal Plain and Piedmont of South Carolina (fig. 42). Data from both regions fall along the envelope curve, indicating that the South Carolina envelope curve can provide an estimate of the upper bound of live-bed pier scour for both regions.

It must be kept in mind that the envelope curve in figure $39 A$ does not imply that all live-bed pier scour in South
Carolina eventually will reach the upper bound of the envelope curve. Each site has unique field and hydraulic characteristics that determine the progression and the limit of scour depth. At some sites, these characteristics will prevent scour depths from reaching the upper-bound envelope curve. The South Carolina live-bed pier-scour envelope curve (fig. 39A) represents an upper bound of pier scour that infrequently will be exceeded for flows near the 100-year flow magnitude. Thus, if one is evaluating scour for an unskewed, 2-ft-wide pier with field conditions similar to those of the current investigation, the envelope curve indicates that live-bed pier scour for such a pier infrequently will exceed a value of $5.6 \mathrm{ft}$. Therefore, the envelope curve can be used to quickly evaluate the potential for live-bed scour for a given pier width, as well as to evaluate the reasonableness of predicted scour. In general, the South Carolina live-bed pier-scour envelope curve can help practitioners develop judgment regarding the range and trend of scour under given field conditions. 


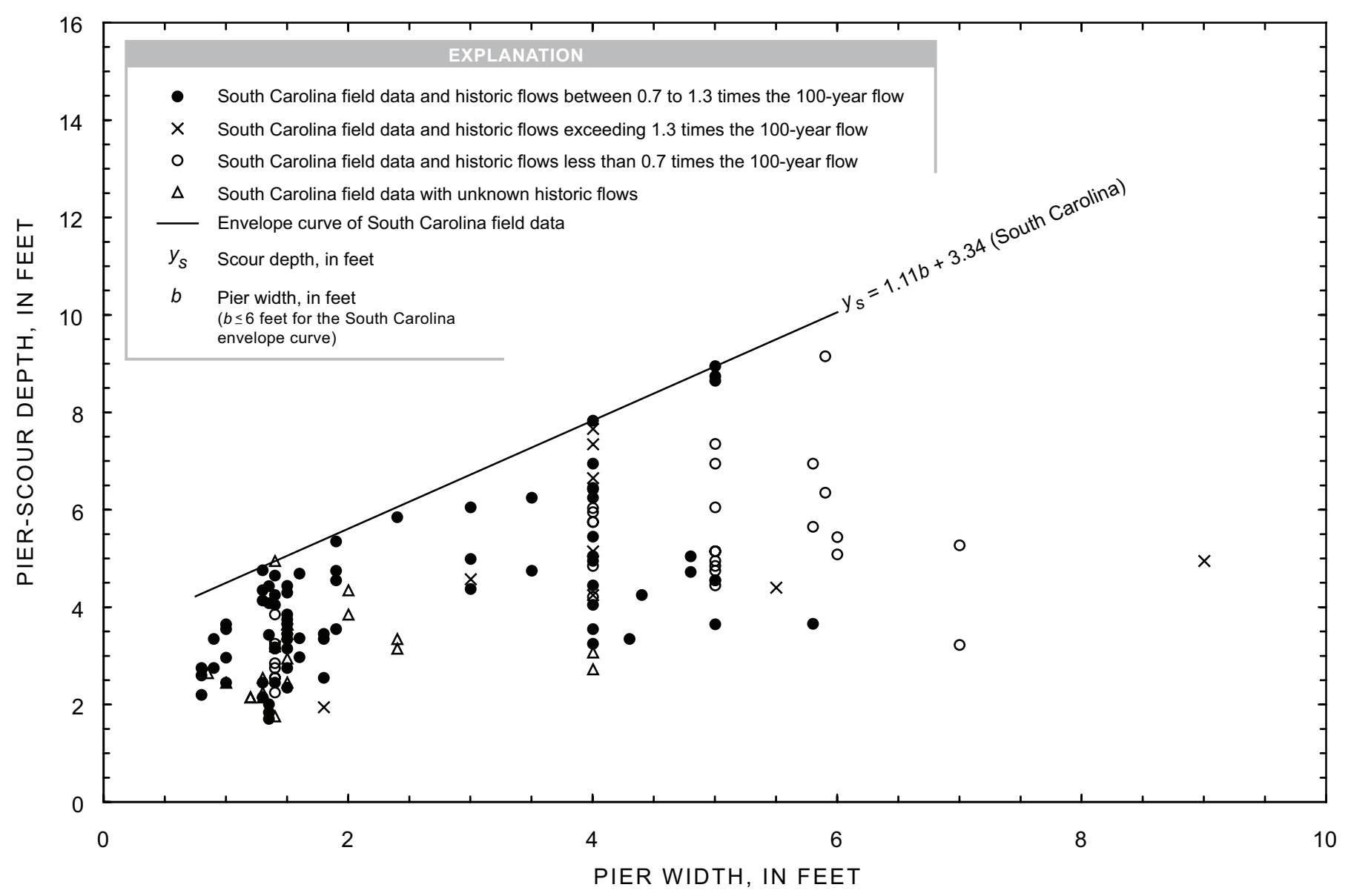

Figure 41. Relation of pier width to measured scour depth for selected sites with known maximum historic flows in South Carolina.

\section{Equation for the South Carolina Pier-Scour Envelope Curve}

The equation for the South Carolina live-bed pier-scour envelope curve is as follows:

$$
y_{s}=1.11 b+3.34
$$

where

$$
\begin{aligned}
& y_{s} \quad \text { is the upper bound of local live-bed pier- } \\
& \text { scour depth, in feet; and } \\
& b \quad \text { is pier width, in feet, and is limited to a value } \\
& \text { of } 6 \text { or less. }
\end{aligned}
$$

This equation can be applied to unskewed, round- and square-shaped piers, and to pile bents with moderate skews (approximately 15 degrees or less) and spacings between piles of approximately 5 pier widths or greater. When skews are thought to influence scour (such as for long, solid piers, severely skewed pile bents, or pile bents with relatively small spacing between piles), a skew-correction coefficient as defined in HEC-18 (Richardson and Davis, 2001) can be applied to equation 6 . Equation 6 was developed for pier widths of $6 \mathrm{ft}$ or less and is not recommended for use outside the limits of the South Carolina data. The South Carolina live-bed envelope curve reflects an upper bound of scour for flows near the 100-year flow magnitude and should be limited to assessing scour for such flows. Additionally, equation 6 was developed from a limited sample of bridges in the Coastal Plain and Piedmont, and scour depths could exceed the envelope curve; therefore, applying a safety factor to equation 6 may be prudent. Using equation 6 initially may appear to be an oversimplified approach to evaluating pier scour, but Benedict and Caldwell (2006) noted that other researchers have proposed equations based on envelope curves of laboratory data that have a similar form to equation 6 , giving justification for this approach. 


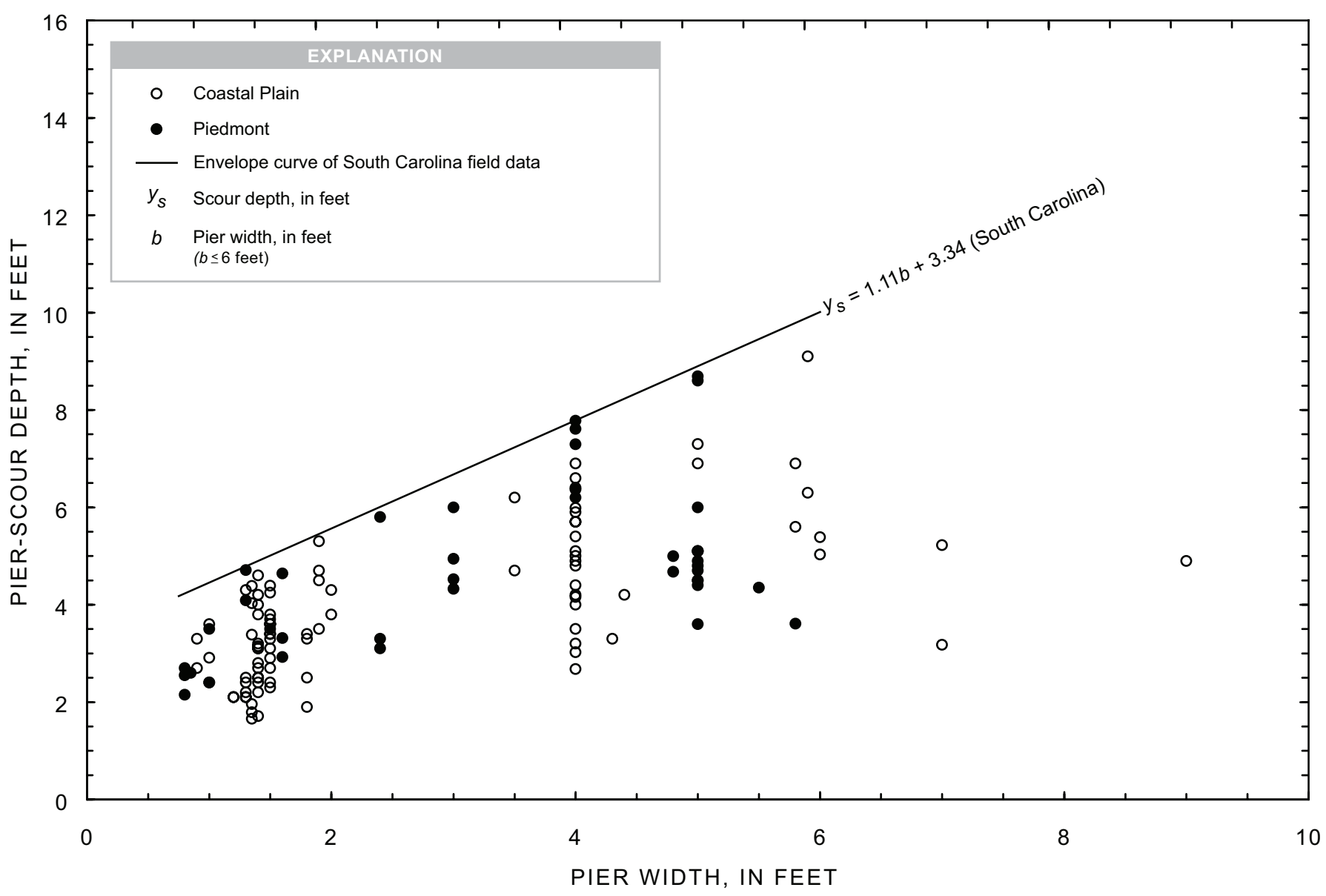

Figure 42. Relation of live-bed pier-scour depth and pier width for selected sites in the Coastal Plain and Piedmont Physiographic Provinces of South Carolina.

\section{Evaluation of Selected Methods for Predicting Live-Bed Pier Scour in South Carolina}

Evaluation tools that consistently provide conservative yet realistic estimates for scour are needed for designing new bridges or evaluating existing bridges for scour. The current methods for predicting scour, as described in HEC-18 (Richardson and Davis, 2001), are in need of field verification and possible modifications to increase accuracy. Additionally, tools derived from field data are needed to help practitioners develop judgment regarding the range and trend of scour within a given region and to help evaluate the reasonableness of predicted scour. The following report sections evaluate the performance of (1) the HEC-18 pier-scour equation (Richardson and Davis, 2001), (2) the modified South Carolina clearwater pier-scour equation (Benedict and Caldwell, 2006), and (3) the South Carolina live-bed pier-scour envelope curve.

\section{The HEC-18 Pier-Scour Equation}

To predict pier-scour depth for live-bed scour conditions, Richardson and Davis (2001) recommend using the HEC-18 pier-scour equation (eq. 2) that initially was derived from laboratory data for noncohesive sediments and later was modified with correction coefficients to account for coarse sediments and wide piers. Using hydraulic variables estimated from the WSPRO model with the estimated historic flows at all sites (78 bridges), predicted pier-scour depths were computed using the HEC-18 pier-scour equation. As noted previously (see report section "Predicted Live-Bed Pier Scour"), 25 pier-scour measurements required a complex pier-scour computation as described in HEC-18 (Richardson and Davis, 2001), and at these piers, both the standard (eq. 2) and complex pier-scour computations were made. Predicted pier-scour depths were compared with measured pier-scour depths for the Coastal Plain and Piedmont regions, as shown in figure 43 . Figure $43 A$ shows the results of predicted scour 

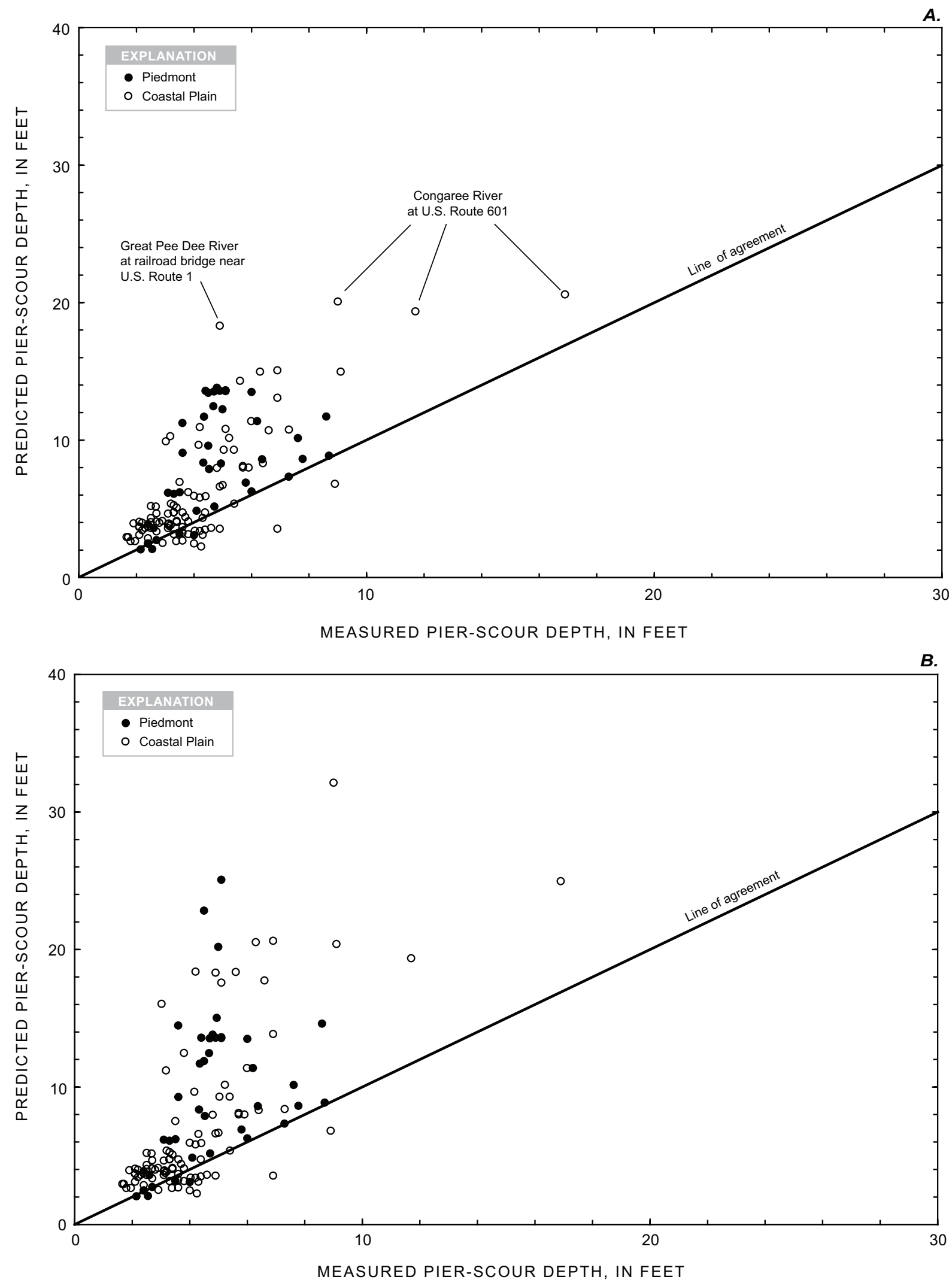

Figure 43. Relation of measured live-bed pier-scour depth to predicted pier-scour depth $(A)$ neglecting the complex pier computation and $(B)$ using the complex pier computation for the maximum historic flows at selected sites in South Carolina. [Predicted pier-scour depth was calculated with the HEC-18 equation (Richardson and Davis, 2001)]. 
based on the standard pier-scour computation (eq. 2), and figure $43 B$ includes data from the 25 complex pier computations. The trends of figure $43 \mathrm{~A}$ indicate that the standard HEC-18 pier-scour equation (eq. 2) underpredicts approximately 16 percent of the data, with underprediction ranging from 0.1 to $3.4 \mathrm{ft}$ with a median value of $0.8 \mathrm{ft}$. The frequency of overprediction is approximately 84 percent of the data, with overprediction ranging from 0.1 to $13.4 \mathrm{ft}$ with a median value of $2.0 \mathrm{ft}$. Benedict and Caldwell (2006) and Mueller and Wagner (2005) noted similar trends for clear-water pier scour in South Carolina and selected data from the NBSD, respectively, with lower rates of underprediction ( 0 and 7 percent, respectively). The higher rate of underprediction in the current investigation (2009) can be attributed, in part, to site-specific features that will be noted in more detail later in this section. In addition to underprediction related to site-specific features, the potential error associated with the GPR interpretation (see previous report section "Selected Data Used in Analysis" and figure 21) also may contribute to the rate of underprediction shown in figure $43 \mathrm{~A}$. Figure $43 \mathrm{~B}$ includes predicted scour associated with the 25 complex pier-scour computations and indicates that when this procedure is applied to complex piers, it tends to produce larger estimates of scour than the standard equation (eq. 2). Based on the results of the current investigation and those of Benedict and Caldwell (2006) and Mueller and Wagner (2005), it is reasonable to conclude that using the HEC-18 standard and complex pier-scour equation generally provides conservative estimates of pier scour that, at times, can produce excessive overprediction (as large as $23 \mathrm{ft}$ for the current investigation [2009]) with occasional underprediction.

Two noteworthy trends are shown in figure $43 \mathrm{~A}$. The three pier-scour measurements associated with the Congaree River at U.S. Route 601 (fig. 43A) are at long, solid piers with approach-flow skew angles of 25 degrees. These were the largest pier-scour depths measured in this investigation, and the large skew at these piers plays a significant role in producing the scour. The 25-degree skew-correction coefficient in the HEC-18 pier-scour equation for these piers is approximately 2 , and without this adjustment, the scour would be underpredicted for two of the three piers. This highlights the importance of the skew-correction coefficient at skewed solid piers. The pier-scour measurement associated with the railroad bridge crossing the Great Pee Dee River near U.S. Route 1 (fig. $43 A$ ) occurs at a 9-ft-wide masonry pier. Based on the SCDOT borings at U.S. Route 1, a hard marl is approximately $5 \mathrm{ft}$ below the channel bed, and this subsurface layer likely is limiting the pier-scour depth at this pier. The significant overprediction $(13.4 \mathrm{ft})$ at this pier is partly caused by this hard subsurface layer.

The relation of pier width to prediction error (predicted scour minus measured scour) for the HEC-18 pier-scour equation is shown in figure 44. Figure $44 A$ shows the results of prediction error based on the standard (eq. 2) pier-scour computation, and figure $44 B$ includes the 25 complex pier computations. The general trend is that prediction error increases with pier width. Additionally, most of the underpredictions can be associated with pier widths of $1.5 \mathrm{ft}$ or less. Seven of the 13 underpredictions at piers with widths of $1.5 \mathrm{ft}$ or less have site features such as contraction scour or indications of past debris accumulations that may increase the pier-scour depth. The piers with underpredictions at S.C. Route 22 crossing the Waccamaw River (fig. 44A) are located on the outside of a large channel bend which tends to increase the scour at these piers. The pier with underpredictions at U.S. Route 15 crossing the Edisto River (fig. 44A) has the remains of an old coffer dam located at the pier which tends to increase the scour at this pier. Based on these observations, it can be helpful when evaluating pier scour to consider site conditions, such as significant contraction scour, channel bends, and remains of old structures, that may increase scour potential.

\section{The South Carolina Modified Pier-Scour Equation}

Benedict and Caldwell (2006) presented the South Carolina modified pier-scour equation for assessing clearwater pier-scour potential on the floodplains of South Carolina streams. The modified equation primarily consisted of removing the correction coefficients from the original HEC-18 pier-scour equation (Richardson and others, 1991). Rearranging the modified equation into a dimensionless power function, Benedict and Caldwell (2006) plotted the laboratory data used to develop the original HEC-18 equation along with the clear-water pier-scour data collected in South Carolina. Using this same procedure, the HEC-18 laboratory data were plotted with the live-bed pier-scour data collected in South Carolina at unskewed piers (fig. 45). (Hydraulic variables for the field data were estimated with the WSPRO model for the estimated maximum historic flow.) The HEC-18 laboratory data represent cylindrical piers, so adjustments for skew or pier shape are not necessary. The power trend line through the laboratory data represents the original regression line developed for the HEC-18 equation.

The South Carolina live-bed pier-scour data have a larger scatter than that of the laboratory data (fig. 45); however, the trend line for the field data is similar to that of the laboratory data, indicating that the South Carolina field data are capturing the anticipated trends for live-bed pier-scour. In the investigation by Benedict and Caldwell (2006), very few of the clear-water pier-scour field data exceeded the trend line of the HEC-18 pier-scour equation shown in figure 45 . The limited number of data exceeding the trend line indicated that for clear-water pier scour on the floodplains of South Carolina (with noted limitations), the correction coefficients in the HEC-18 pier-scour equation could be removed while maintaining limited underprediction and reducing overprediction. The trends in figure 45, however, show that a significant number of the live-bed pier-scour data for South Carolina exceed the line of the HEC-18 pier-scour equation, indicating that the modified equation presented by Benedict and Caldwell (2006) is not appropriate for live-bed pier scour in South Carolina. 

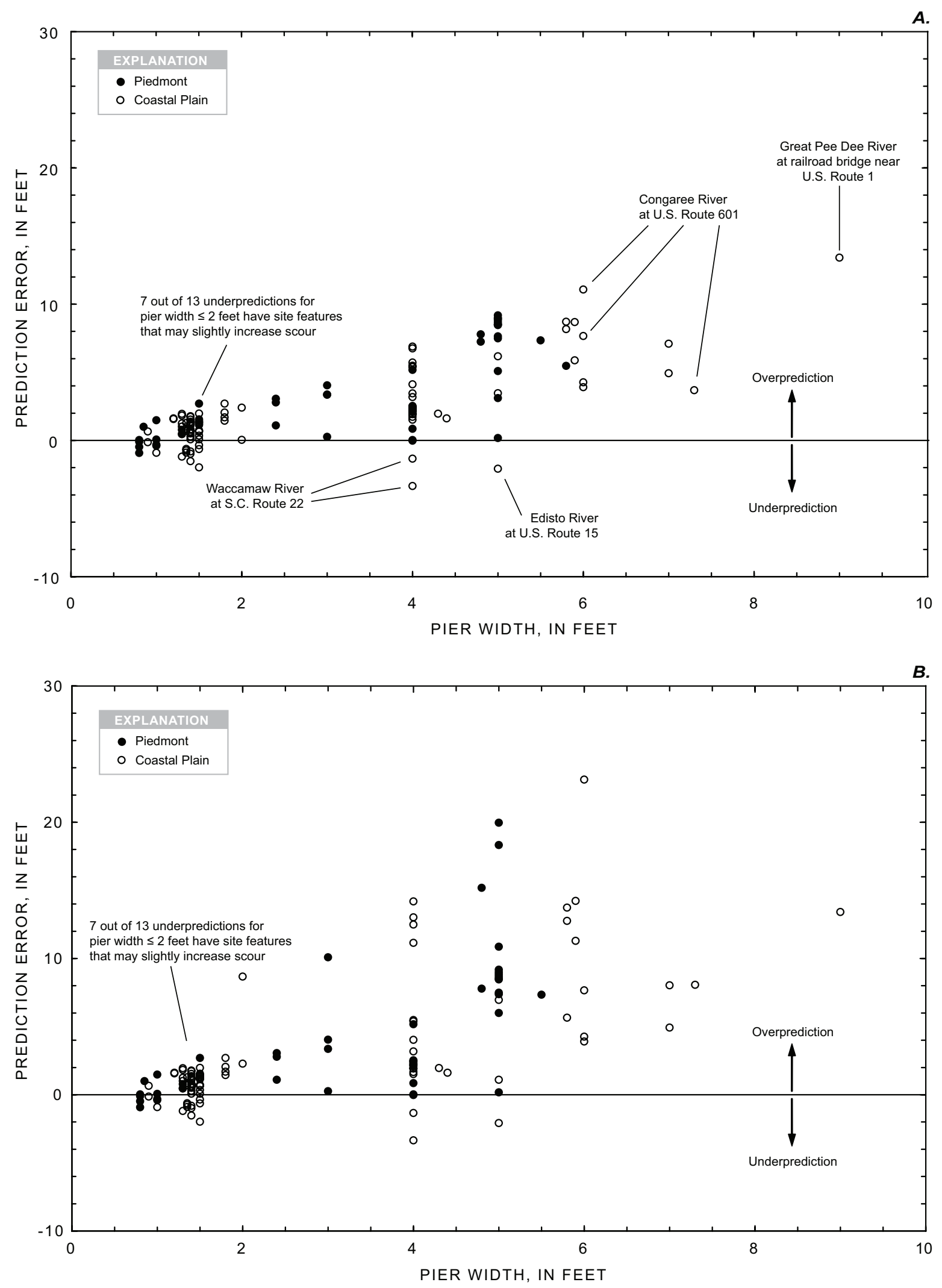

Figure 44. Relation of pier width to prediction error $(A)$ neglecting the complex pier computation and $(B)$ using the complex pier computation for live-bed pier-scour depth using the HEC-18 pier-scour equation (Richardson and Davis, 2001) for selected sites in the Coastal Plain and Piedmont Physiographic Provinces of South Carolina. 


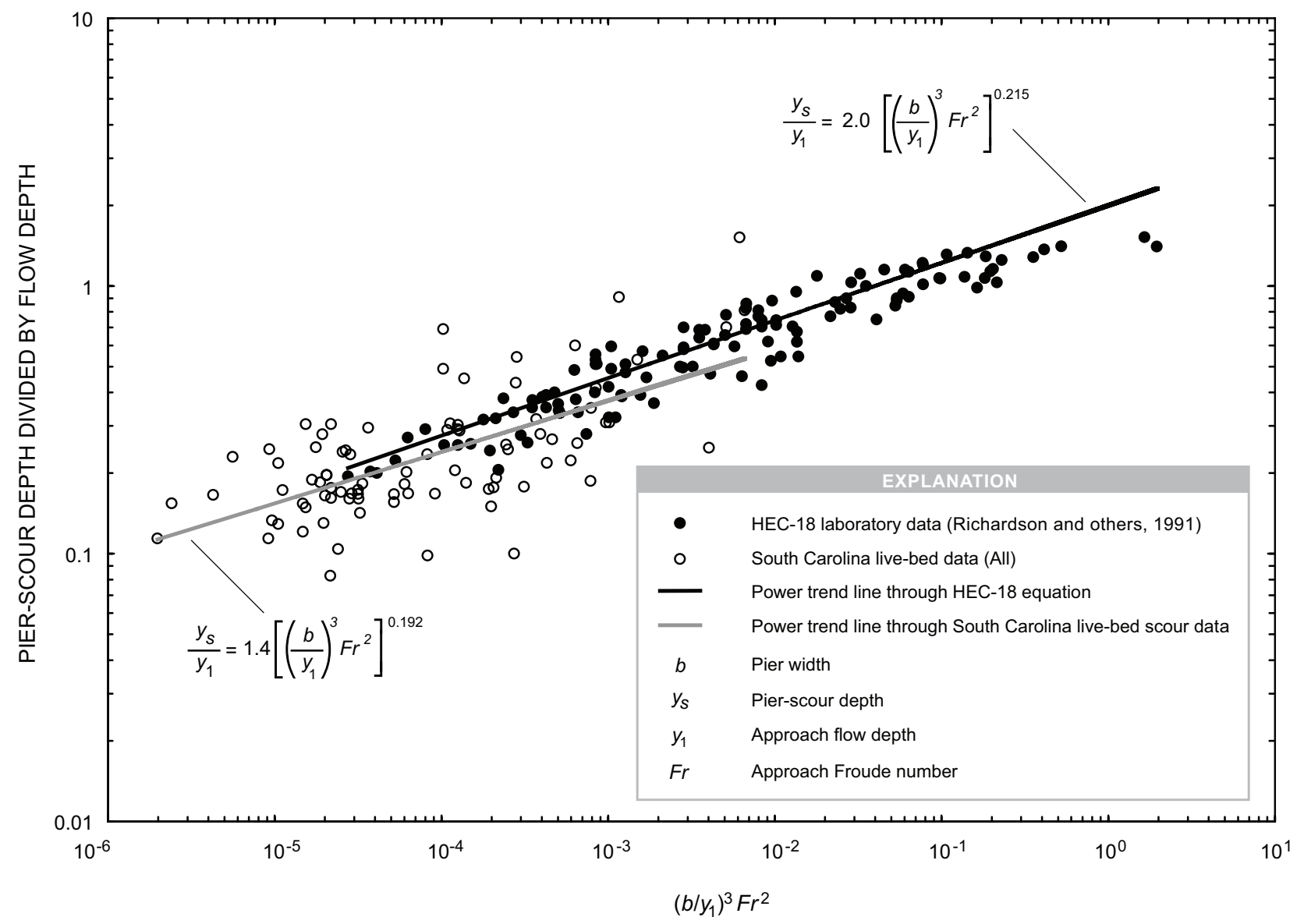

Figure 45. Relation of relative scour to the dimensionless variable, $\left(b / y_{1}\right)^{3} \mathrm{Fr}^{2}$, for laboratory data used to develop the original HEC-18 pier-scour equation (Richardson and others, 1991) and data from selected sites in South Carolina.

The relation of the predicted and measured pier scour using the South Carolina modified pier-scour equation (Benedict and Caldwell, 2006) is shown in figure 46. For pile bents with skews of 15 degrees or less, no adjustment for skew was made. For pile bents with skews greater than 15 degrees and for solid piers with any skew, the skew-correction coefficient from the HEC-18 pier-scour equation (Richardson and Davis, 2001) was applied to the South Carolina modified pier-scour equation (Benedict and Caldwell, 2006). While excessive overprediction was slightly improved, the number of underpredictions increased in comparison to the HEC-18 pier-scour equation (fig. 43), indicating that the South Carolina modified pier-scour equation (Benedict and Caldwell, 2006) should not be used for assessing live-bed pier scour in South Carolina.

\section{The South Carolina Live-Bed Pier-Scour Envelope Curve}

The South Carolina live-bed pier-scour envelope curve (fig. 39; eq. 6) can be used to evaluate potential scour in South Carolina. Because the envelope curve represents the upper bound of observed data, it tends to overpredict pier scour, and at times this overprediction may be excessive. The relation of measured to predicted scour, determined with the South Carolina envelope curve (eq. 6), is plotted in figure 47 . For pile bents with skews of 15 degrees or less, no adjustment for skew was made. For pile bents with skews greater than 15 degrees and for solid piers with any skew, the 


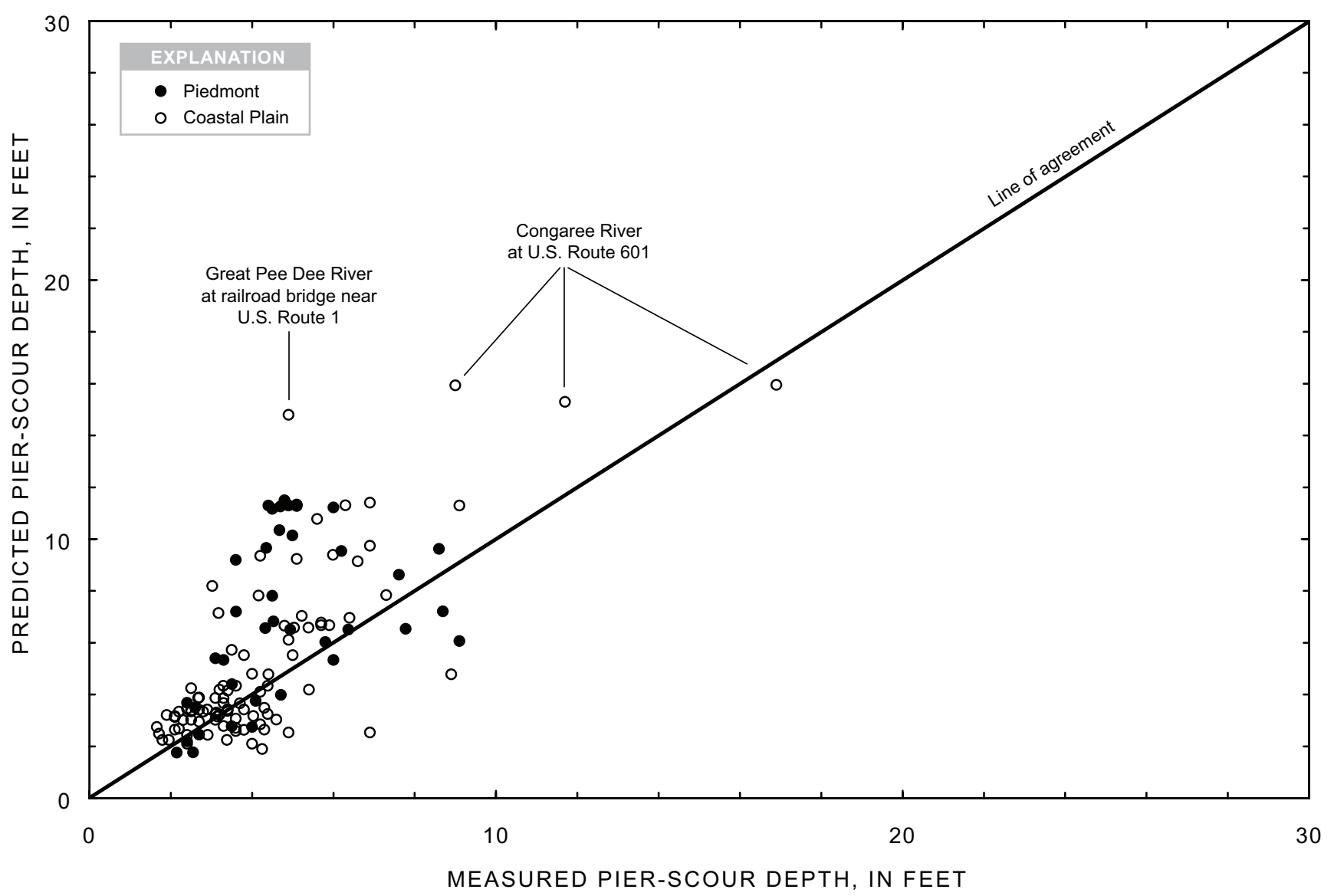

Figure 46. Relation of measured live-bed pier-scour depth to the predicted pier-scour depth for maximum historic flows at selected sites in South Carolina. [Predicted pier scour was calculated with the South Carolina modified pier-scour equation (Benedict and Caldwell, 2006).]

skew-correction coefficient from the HEC-18 pier-scour equation (Richardson and Davis, 2001) was applied to the South Carolina live-bed pier-scour envelope curve. Comparison of the results of the envelope curve (fig. 47) with those of the HEC-18 pier-scour equation (Richardson and Davis, 2001; fig. 43) indicates that the South Carolina live-bed pier-scour envelope curve performs in a similar manner to the HEC-18 pier-scour equation, with the range of overprediction for the HEC-18 pier-scour equation being 0.1 to $13.4 \mathrm{ft}$ with a median of $2 \mathrm{ft}$, and the overprediction for the South Carolina live-bed pier-scour envelope curve being 0.1 to $12.0 \mathrm{ft}$ with a median of $2.5 \mathrm{ft}$. The benefit of the envelope curve is that there is no underprediction.

To validate the South Carolina pier-scour envelope curve (eq. 6) as a tool for obtaining quick, yet conservative, estimates of pier-scour depth, all data from the NBSD (500 measurements) were used for verification. Pier width for these data range from 0.95 to $18.1 \mathrm{ft}$ with measured pier-scour depth ranging from 0 to $25.1 \mathrm{ft}$. The relation of measured to predicted scour, based on equation 6 , is shown in figure 48 . Of the 500 measurements of pier-scour depth, 14 were underpredicted by equation 6 , with a maximum underprediction of $6.2 \mathrm{ft}$, a minimum underprediction of $0.1 \mathrm{ft}$, and an average underprediction of $2.0 \mathrm{ft}$. Overprediction was excessive at times, with a maximum value of $19.8 \mathrm{ft}$ and an average of $5.2 \mathrm{ft}$. Figure 48 also displays selected NBSD data with pier widths of $6 \mathrm{ft}$ or less. For this width category, overprediction ranges from 0.8 to $8.9 \mathrm{ft}$, and only one measurement was underpredicted, with a value of $0.6 \mathrm{ft}$. The trends in figure 48 indicate that the South Carolina live-bed pier-scour envelope curve (eq. 6) will, in general, provide quick and conservative estimates of pier-scour depth with infrequent and minimal underprediction, but excessive overprediction at times. Based on the trends shown in figure 48, the live-bed pier-scour envelope-curve equation appears to perform well when pier widths are $6 \mathrm{ft}$ or less. 


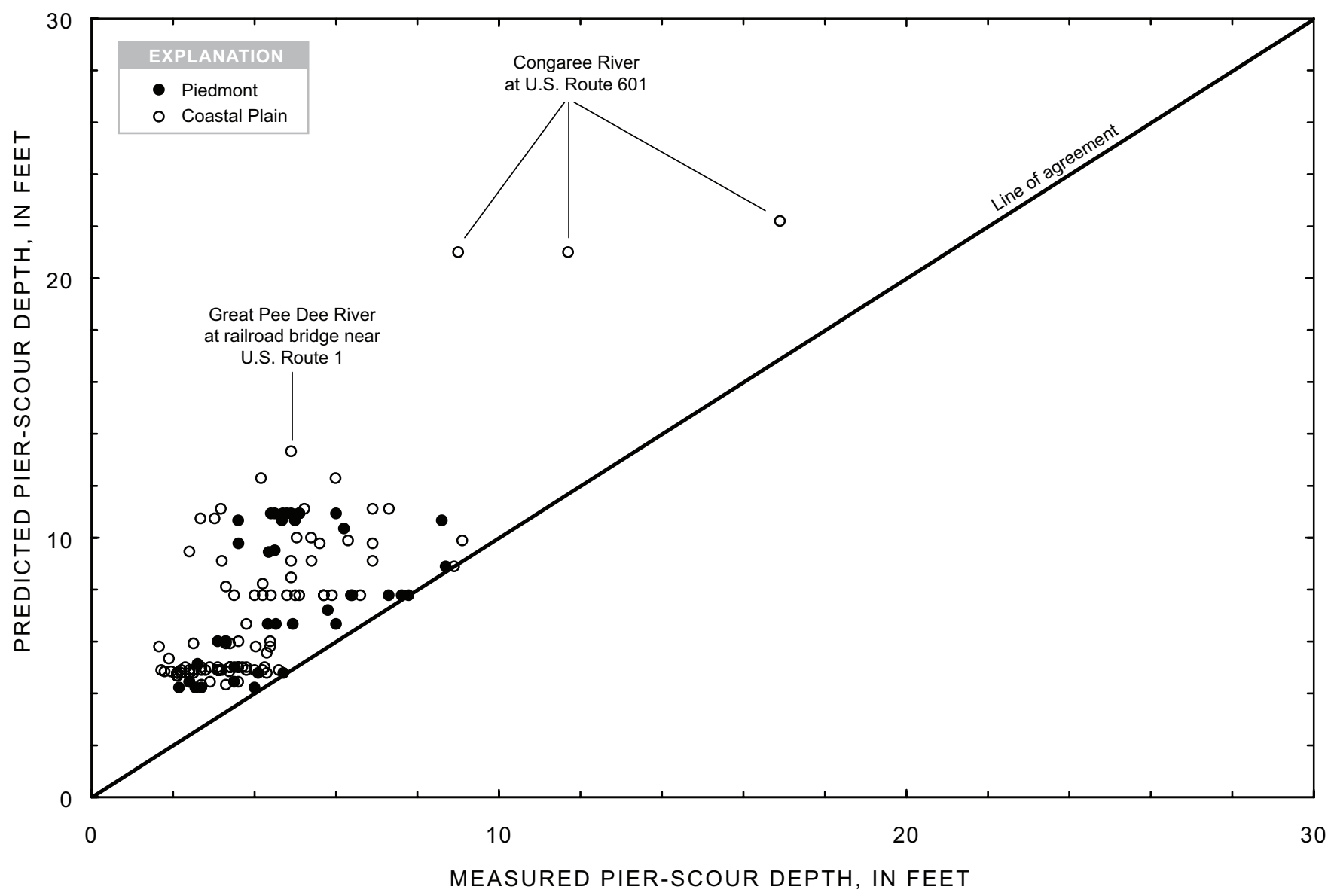

Figure 47. Relation of measured to predicted live-bed pier-scour depth for selected sites in the Coastal Plain and Piedmont Physiographic Provinces of South Carolina. [Predicted pier scour was calculated with the South Carolina live-bed pier-scour envelope-curve equation using the skew correction coefficients from the HEC-18 pier-scour equations (Richardson and Davis, 2001).]

\section{Guidance for Evaluating Live-Bed Pier-Scour Depth in South Carolina}

Based on the findings of this investigation, the following guidance is provided for evaluating potential live-bed pierscour depths in South Carolina. Scour prediction is an imprecise science, and the practitioner must rely on judgment when making a final estimate of pier scour. Current scour-prediction methods along with the field evaluation tools developed in this investigation should be used to make such evaluations. The methods developed in this investigation for evaluating scour are empirical, and application of the methods should be limited to sites with similar characteristics to those used in this investigation. Additionally, the envelope curves were developed from a limited sample of bridges in the Coastal Plain and Piedmont, and scour depths could exceed the envelope curves. Therefore, applying a safety factor to the envelope curves may be prudent. Because live-bed pier-scour data collected during this investigation were limited to pier widths of approximately $6 \mathrm{ft}$ and less, guidance is separated into categories for pier widths less than or equal to $6 \mathrm{ft}$ and categories for pier widths greater than $6 \mathrm{ft}$.

\section{Evaluating Scour Depth at Pier Widths Less Than or Equal to 6 Feet}

For pier widths less than or equal to $6 \mathrm{ft}$, empirical methods developed in this investigation can be used to help evaluate the potential for live-bed pier scour. It is important, however, to initially determine if the site of interest has characteristics similar to those used in this study. This can be accomplished by comparing characteristics at the site of interest to those presented in tables 3 and 4 and figures 3 and 4, which display the ranges and trends of selected site 


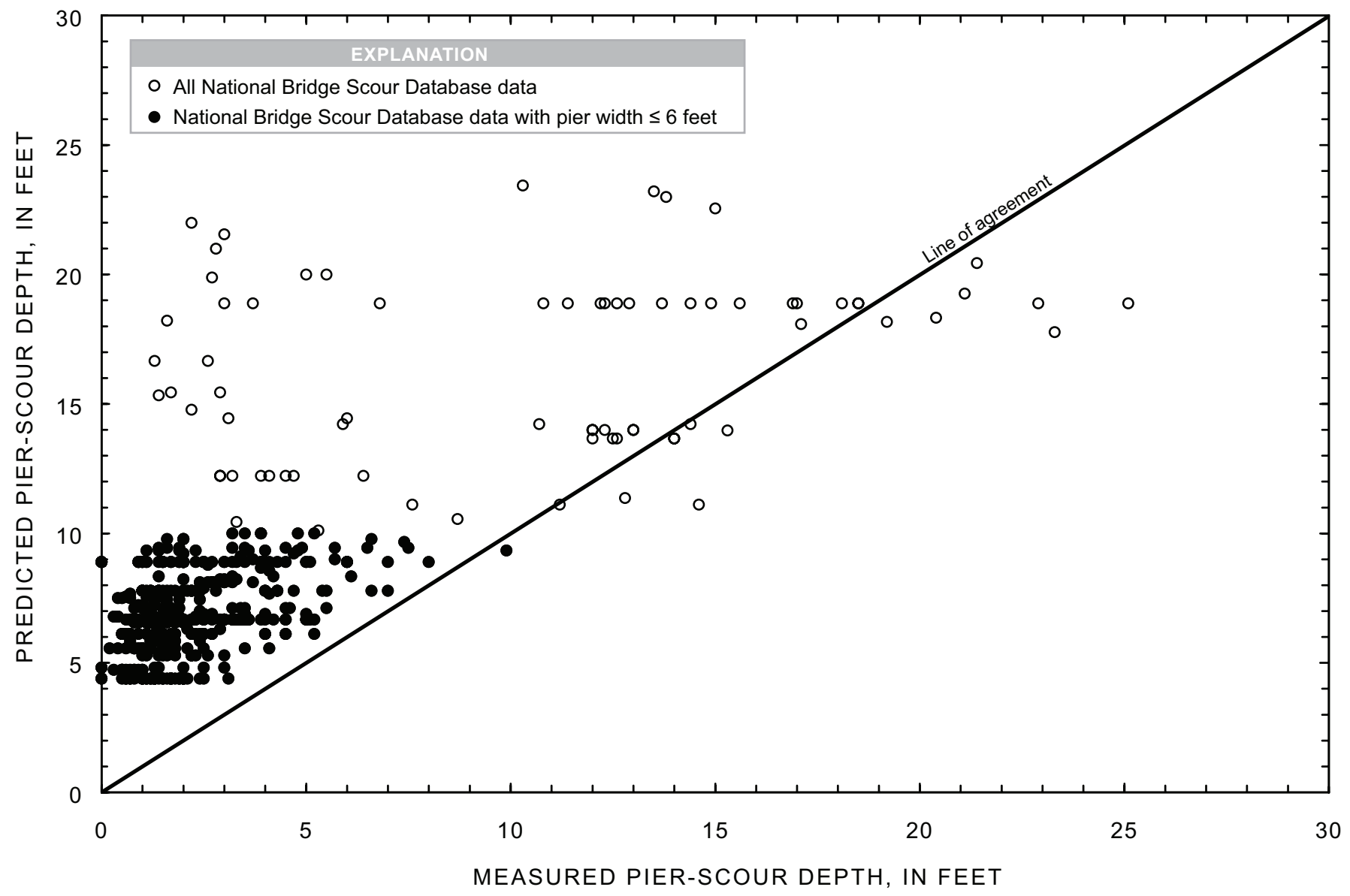

Figure 48. Relation of measured to predicted pier scour using the South Carolina live-bed pier-scour envelope-curve equation for all data in the National Bridge Scour Database.

characteristics for the data used in this investigation. The methods presented in this report are not intended for tidally influenced sites or for sites where pier scour may be influenced by debris. If site conditions are similar to those used in this investigation, the following guidance can be applied.

For quick evaluations of potential live-bed pier scour at unskewed solid piers and at pile bents with skews of approximately 15 degrees or less and pile spacings of approximately 5 pile widths, the South Carolina live-bed pier-scour envelope curve (eq. 6) can be used. When the pier or pile bent does not comply with the skew conditions noted above, it is important to apply the HEC-18 pier-scour-equation skew-correction coefficient to equation 6 , following the guidance in HEC-18 (Richardson and Davis, 2001). Based on results shown in figures 43 and 47, equation 6 will provide estimates of scour similar to those of the HEC-18 pier-scour equation (Richardson and Davis, 2001) and possibly with less frequent underprediction. After estimating potential scour by using equation 6 , the South Carolina Live-Bed Scour Database (SCLBSD; appendix 1) and the NBSD should be queried for comparison sites that can be used to evaluate the reasonableness of the estimated scour. The results of this evaluation should be compared with the HEC-18 pier-scour equation (Richardson and Davis, 2001) before a final estimate of scour potential is made.

Because of the limitations associated with both the South Carolina live-bed pier-scour envelope curve and the HEC-18 pier-scour equation (Richardson and Davis, 2001), judgment must be used when selecting the final estimate of scour. The South Carolina pier-scour envelope curve was developed using field data from sites with flows near the 100-year flow and should not be used to evaluate live-bed pier-scour depths for extreme conditions, such as the 500-year flow.

\section{Evaluating Scour Depth at Pier Widths Greater Than 6 Feet}

When pier widths in South Carolina exceed $6 \mathrm{ft}$, the South Carolina live-bed pier-scour envelope curve may not be applicable. The plotted data in figure 48 indicate that the South Carolina live-bed pier-scour envelope curve (eq. 6) performs fairly well with the NBSD data; however, some underprediction occurs when pier width exceeds $6 \mathrm{ft}$, bringing into question its use for such piers. Other alternatives for evaluating 
Table 3. Range of selected characteristics for 42 measurements of live-bed pier scour collected at 30 bridges in the Piedmont Physiographic Province of South Carolina.

$\left[\mathrm{mi}^{2}\right.$, square mile; $\mathrm{ft} / \mathrm{ft}$, foot per foot; $\mathrm{ft} / \mathrm{s}$, foot per second; $\mathrm{ft}$, foot; $\mathrm{mm}$, millimeter]

\begin{tabular}{lccc}
\hline \multicolumn{1}{c}{ Characteristic } & $\begin{array}{c}\text { Minimum } \\
\text { value }\end{array}$ & $\begin{array}{c}\text { Median } \\
\text { value }\end{array}$ & $\begin{array}{c}\text { Maximum } \\
\text { value }\end{array}$ \\
\hline $\begin{array}{l}\text { Drainage area }\left(\mathrm{mi}^{2}\right) \\
\text { Channel slope determined } \\
\text { from topographic map } \\
(\mathrm{ft} / \mathrm{ft})\end{array}$ & 0.00015 & 0.00070 & $5,250^{\mathrm{a}}$ \\
& & & 0.00156 \\
\end{tabular}

\begin{tabular}{llcc}
$\begin{array}{l}\text { Average approach-flow } \\
\text { velocity at pier face } \\
\text { based on maximum } \\
\text { historic flow (ft/s) }\end{array}$ & 1.7 & 7.1 & 9.6 \\
$\begin{array}{c}\text { Average approach-flow } \\
\text { depth at pier face based } \\
\text { on maximum historic } \\
\text { flow (ft) }\end{array}$ & 6.8 & 19.3 & 27.1 \\
$\begin{array}{l}\text { Pier width (ft) } \\
\text { Pier skew (degrees) }\end{array}$ & 0.8 & 4 & 5.8 \\
$\begin{array}{l}\text { Median grain size (mm) } \\
\begin{array}{l}\text { Observed pier-scour } \\
\text { depth (ft) }\end{array}\end{array}$ & 0.5 & 8 & 30 \\
\hline
\end{tabular}

${ }^{a}$ Approximately 94 percent of the study sites in the Piedmont have drainage areas less than $760 \mathrm{mi}^{2}$ (figure 4).

b Values were estimated from the one-dimensional water-surface profile model, WSPRO (Shearman, 1990).

scour at pier widths greater than $6 \mathrm{ft}$ are the HEC-18 equation (eq. 2) and the envelope of the NBSD data as presented in figure 40. (Note: Skew-correction coefficients should be applied to the envelope of the NBSD data.) Potential scour should be evaluated with both of these methods, and the practitioner should select the most reasonable estimate based on judgment. After potential scour is estimated, the NBSD should be queried for comparison sites that can be used to evaluate the reasonableness of the estimated scour. Because of the limitations associated with both the NBSD pier-scour envelope curve and the HEC-18 pier-scour equation (Richardson and Davis, 2001), judgment must be used when selecting the final estimate of scour.

\section{Evaluating Top Widths of Pier-Scour Holes}

In addition to pier-scour depth at a given site, the geometry and location of the pier-scour hole also are important. Laboratory and field data indicate that pier-scour holes are located near the pier, and for practical purposes, pier-scour holes are assumed to be symmetrical around the pier. HEC-18
Table 4. Range of selected characteristics for 99 measurements of live-bed pier scour collected at 45 bridges in the Coastal Plain Physiographic Province of South Carolina.

$\left[\mathrm{mi}^{2}\right.$, square mile; $\mathrm{ft} / \mathrm{ft}$, foot per foot; $\mathrm{ft} / \mathrm{s}$, foot per second; $\mathrm{ft}$, foot; $\mathrm{mm}$, millimeter]

\begin{tabular}{|c|c|c|c|}
\hline Characteristic & $\begin{array}{l}\text { Minimum } \\
\text { value }\end{array}$ & $\begin{array}{l}\text { Median } \\
\text { value }\end{array}$ & $\begin{array}{l}\text { Maximum } \\
\text { value }\end{array}$ \\
\hline Drainage area $\left(\mathrm{mi}^{2}\right)$ & 17.2 & 1,030 & $9,360^{\mathrm{a}}$ \\
\hline $\begin{array}{l}\text { Channel slope determined } \\
\text { from topographic map } \\
(\mathrm{ft} / \mathrm{ft})\end{array}$ & 0.00007 & 0.00028 & 0.00200 \\
\hline $\begin{array}{l}\text { Average approach-flow } \\
\text { velocity at pier face } \\
\text { based on maximum } \\
\text { historic flow }(\mathrm{ft} / \mathrm{s})^{\mathrm{b}}\end{array}$ & 0.8 & 4.2 & 8.8 \\
\hline $\begin{array}{l}\text { Average approach-flow } \\
\text { depth at pier face based } \\
\text { on maximum historic } \\
\text { flow (ft) }{ }^{b}\end{array}$ & 2.8 & 15.6 & 50.8 \\
\hline Pier width (ft) & 0.9 & 1.5 & 9 \\
\hline Pier skew (degrees) & 0 & 0 & 30 \\
\hline Median grain size (mm) & 0.24 & 0.64 & 1.7 \\
\hline $\begin{array}{l}\text { Observed pier-scour } \\
\text { depth (ft) }\end{array}$ & 1.7 & 3.8 & 16.9 \\
\hline \multicolumn{4}{|c|}{$\begin{array}{l}{ }^{\text {a }} \text { Approximately } 80 \text { percent of the study sites in the Coastal Plain have } \\
\text { drainage areas less than } 1,860 \mathrm{mi}^{2} \text { (figure } 4 \text { ). }\end{array}$} \\
\hline
\end{tabular}

(Richardson and Davis, 2001) recommends the following equation for estimating the top width of a pier-scour hole.

$$
T W=4 y_{s}+b
$$

where

$$
\begin{array}{cl}
T W & \text { is the top width of the pier-scour hole, in feet; } \\
y_{s} & \text { is the pier-scour depth, in feet; and } \\
b & \text { is the pier width, in feet. }
\end{array}
$$

The top widths of pier-scour holes, when readily defined in the GPR data, were estimated for the current investigation, and these data can be used to evaluate the performance of equation 7. Horizontal distances in the GPR data are approximated from limited reference points; therefore, the pier-scour hole top widths will have error associated with them. This error should be kept in mind when viewing the following relations. The relation of measured pier-scour hole top width to predicted pier-scour hole top width (estimated with equation 7) and the measured pier-scour depth in the Coastal Plain and Piedmont of South Carolina were plotted (figs. 49 and 50, respectively). The HEC-18 equation (eq. 7) for estimating the top width of a pier-scour hole has significant scatter around 


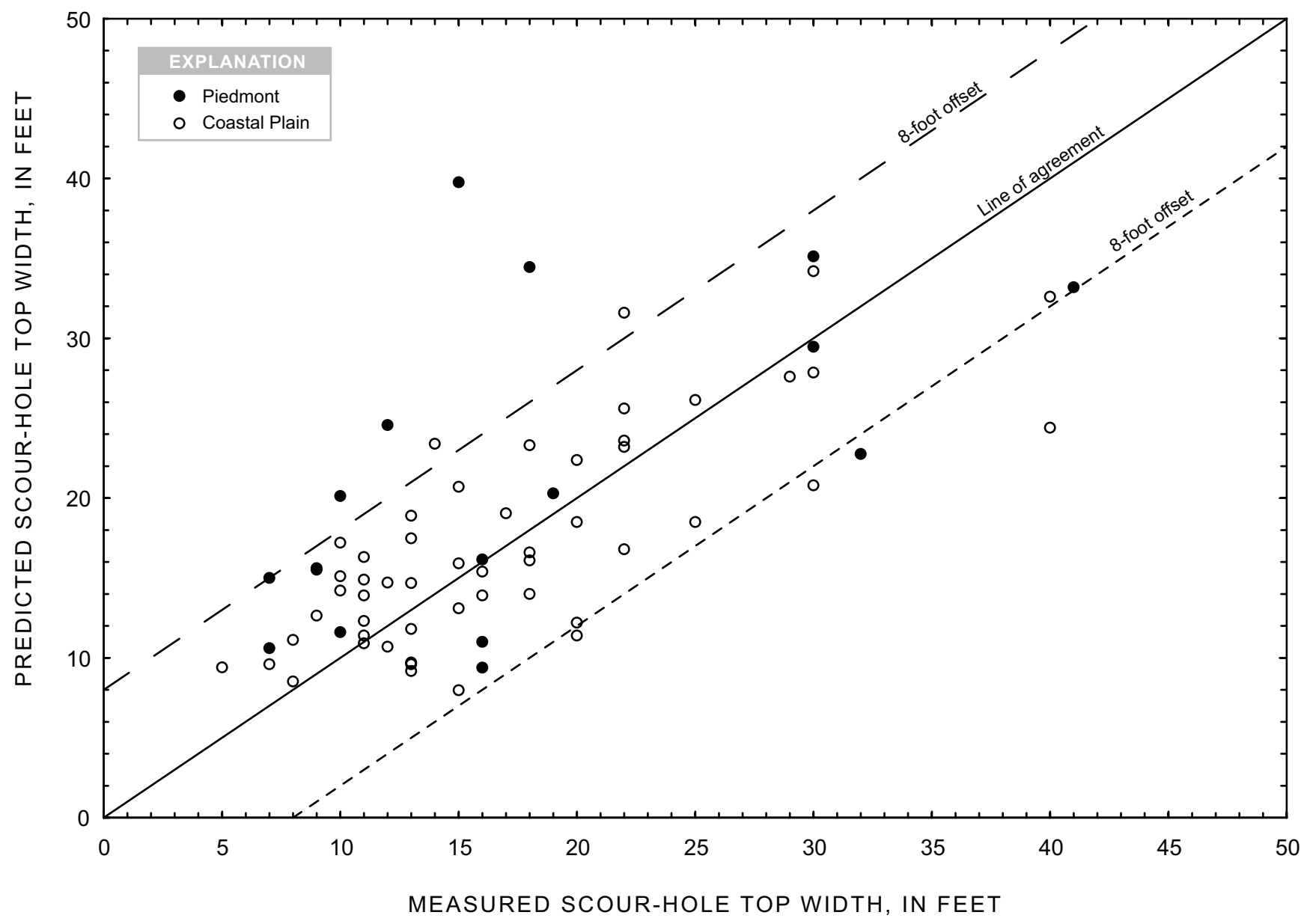

Figure 49. Relation of measured scour-hole top width to predicted scour-hole top width based on the HEC-18 equation (Richardson and Davis, 2001) for selected sites in the Coastal Plain and Piedmont Physiographic Provinces of South Carolina.

the line of agreement; however, the scatter is well distributed about the line of agreement, indicating that the equation is capturing the general trend of the field data. Additionally, most of the error is within $\pm 8 \mathrm{ft}$ from the line of agreement, indicating that equation 7 may be useful for obtaining insights to scour-hole top widths for live-bed pier scour in South Carolina. Figure 50 shows the relation of the measured pier-scour depth to measured top width minus the pier width $(T W-b)$.

The pier width was subtracted from the top width to determine if the value of 4 used as the slope in equation 7 is reasonable. Forcing the y-intercept to 0 , the trend line through the data has a slope of 3.6; therefore, it may be appropriate to modify equation 7 as follows:

$$
T W=3.6 y_{s}+b
$$

where variables are as previously defined. Equation 8 is an average line with an underprediction rate of about 50 percent, and it should be used with caution.

The relation of pier width to scour-hole top width for the measured pier scour in the Coastal Plain and Piedmont of
South Carolina was plotted (fig. 51). The trend line through the data indicates that the top width of the pier-scour hole increases with pier width. The upper-bound envelope curve was developed by arbitrarily shifting the trend line to encompass all of the data (fig. 51). The trend line can be used to estimate an average top width of the scour hole for pier widths of $6 \mathrm{ft}$ or less. For a more conservative estimate of the top width, the upper-bound envelope curve can be used.

\section{Development of the South Carolina Live-Bed Contraction-Scour Envelope Curves}

Previous investigations of clear-water contraction scour in South Carolina (Benedict, 2003; Benedict and Caldwell, 2006) identified weaknesses in the clear-water contractionscour prediction methods presented in HEC-18 (Richardson and Davis, 2001) and presented field-derived envelope curves 


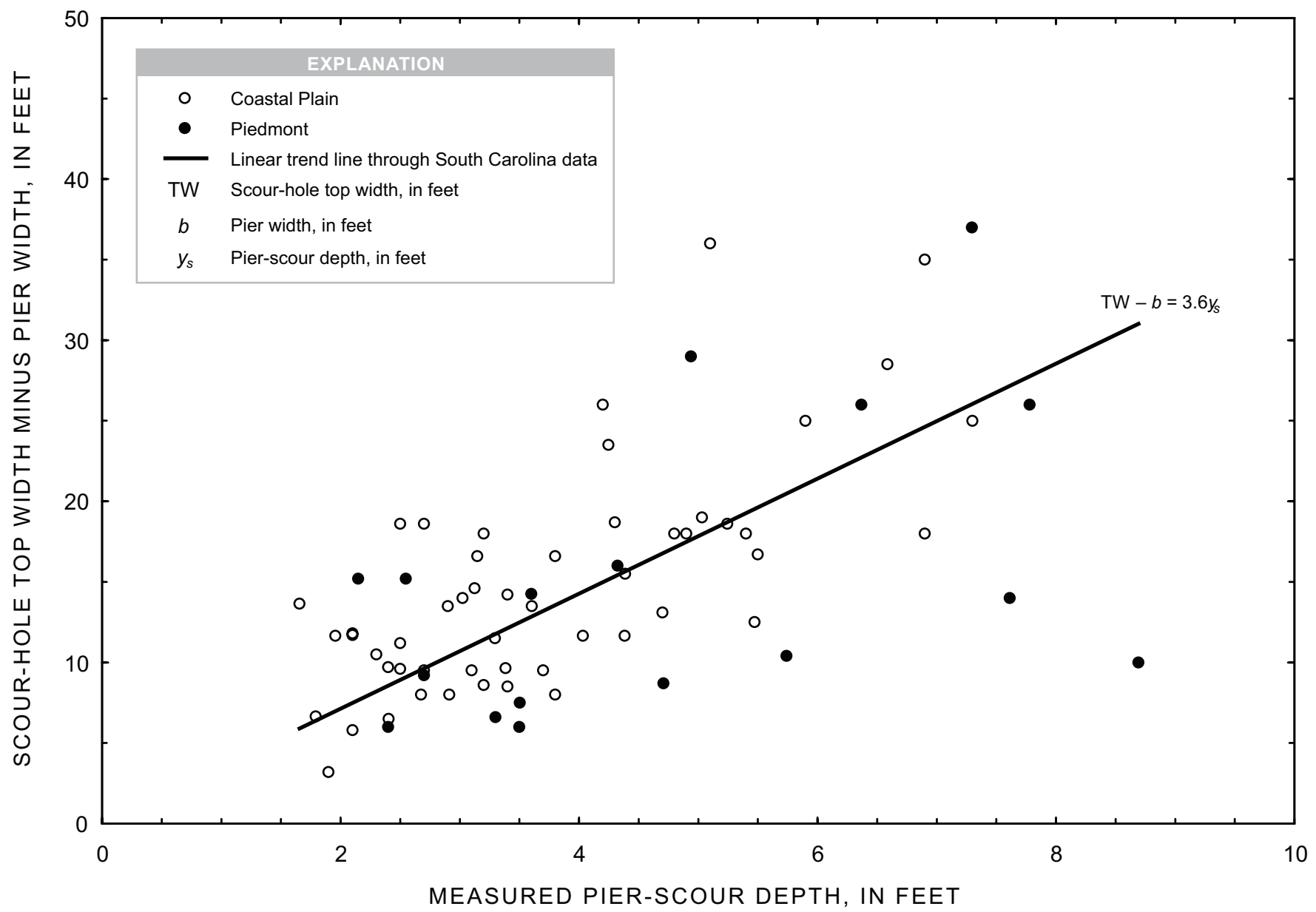

Figure 50. Relation of measured pier-scour depth to scour-hole top width minus the pier width for selected sites in the Coastal Plain and Piedmont Physiographic Provinces of South Carolina.

to help assess the potential for clear-water contraction scour in the Piedmont and Coastal Plain of South Carolina. Using a similar approach, live-bed contraction-scour data collected in the Piedmont and Coastal Plain of South Carolina were analyzed, and envelope curves that display the range and trend of live-bed contraction scour in South Carolina were investigated. The following sections present (1) a description of the field data and its limitations; (2) a comparison of measured and predicted scour using the HEC-18 prediction equation (Richardson and Davis, 2001); (3) a review of selected dimensionless relations in the data; (4) a description of the field-derived envelope curve; and (5) guidance for evaluating the potential for live-bed contraction scour in the Coastal Plain and Piedmont of South Carolina.

\section{Live-Bed Contraction Scour in the Coastal Plain and Piedmont}

Bridge contraction scour occurs when a bridge significantly constricts the natural flow of a stream and causes the streambed to erode in the general region of the bridge. The mechanisms that create the contraction scour are associated with increased flow velocities and vortices generated by the constriction of flow. Contraction scour is generally classified as clear-water or live-bed, which refer to the sedimenttransport conditions at the time of scour (Richardson and Davis, 2001). Clear-water contraction scour occurs when approach-flow velocities are insufficient to transport sediments along the bed and into the scoured region. Equilibrium conditions for clear-water contraction scour are attained when flow velocities in the contraction have been reduced by bed degradation to the critical velocity of the bed sediments. In contrast, live-bed contraction scour occurs when approach-flow velocities are sufficient to transport bed sediments into the scoured region. Equilibrium conditions for live-bed contraction scour are attained when bed-sediment transport into and out of the scoured region are equal. As noted previously for pier scour, the prevailing sediment-transport conditions will influence the rate at which scour develops (fig. 23); therefore, researchers have typically distinguished between live-bed and clear-water contraction scour in their investigations. Understanding the 


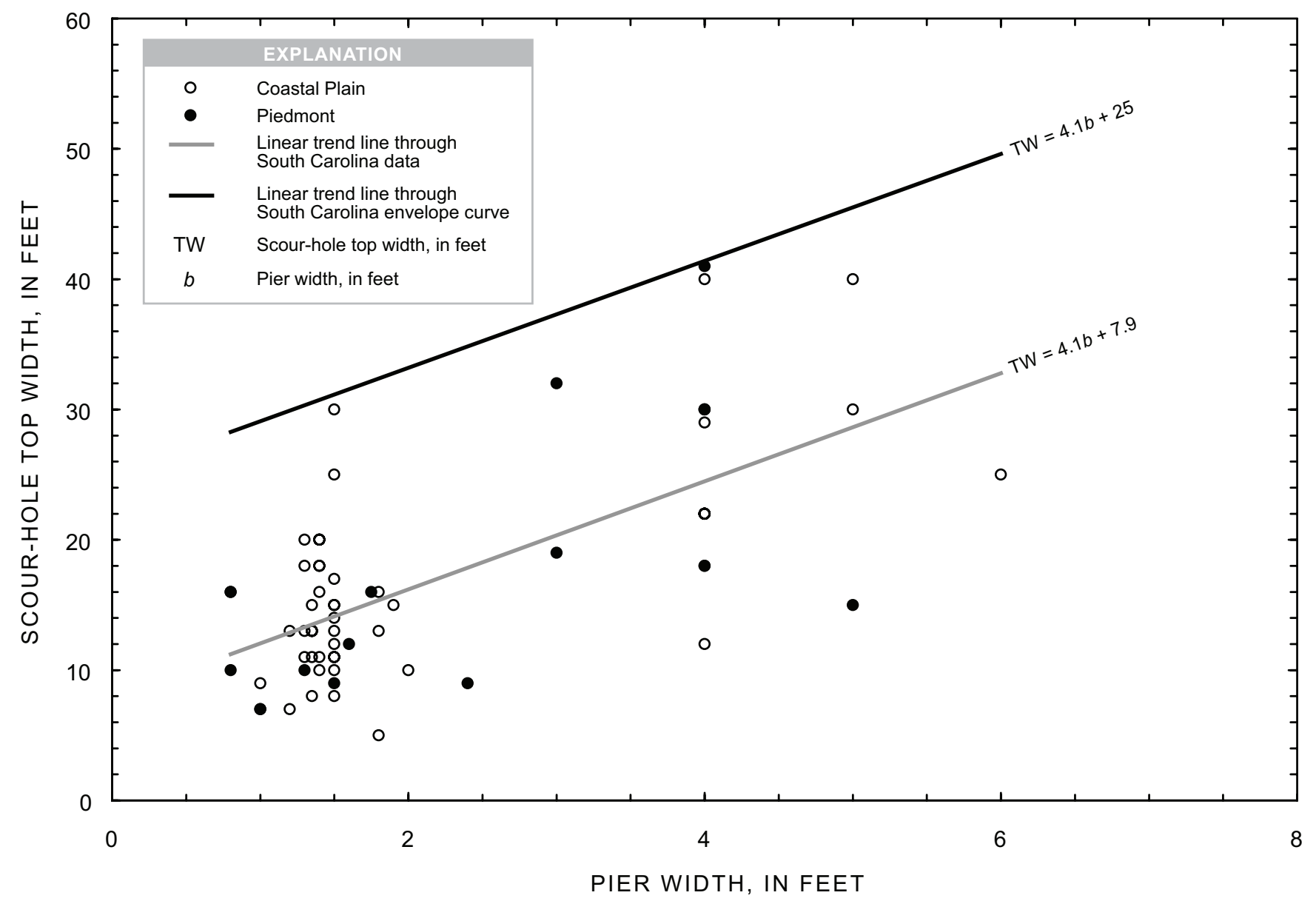

Figure 51. Relation of pier width to scour-hole top width for selected sites in the Coastal Plain and Piedmont Physiographic Provinces of South Carolina.

differences between live-bed and clear-water scour conditions is important; however, it should be noted that the scour processes are similar and the maximum contraction-scour depths associated with these types of scour also are similar. As documented in previous investigations (Benedict, 2003; Benedict and Caldwell, 2006), clear-water contraction scour in South Carolina typically occurs on the floodplain where flow velocities are relatively small and the soils are relatively stable. In contrast, live-bed contraction scour in South Carolina typically occurs in the main channel of a stream where flow velocities are relatively large and loose sediments are readily available for transport.

The field data in the current investigation includes 89 measurements of live-bed contraction scour collected at 89 bridges. Twelve of the 89 bridges are old abandoned highway bridges, other highway bridges, or railroad bridges located near a primary bridge of interest. The remaining 77 bridges are the primary bridge sites where live-bed scour data were collected. (Note: Data were collected at 78 bridges; however, one site had features that prevented the determination of live-bed contraction scour and was not included in the analysis.) Because of the difficulty and uncertainty of defining live-bed contraction scour, two estimates of scour were often determined from the GPR data. The "most likely estimate of measured scour" represents the interpreter's judgment of the maximum historic live-bed contraction scour that most likely had occurred at that site. At sites where the GPR data were ambiguous, a second and more conservative interpretation of live-bed contraction scour was made and was called the "worst-case estimate of measured scour." These terms will be defined in more detail later in the report.

A total of 54 measurements of live-bed contraction scour were collected at 54 bridges in the Coastal Plain of South Carolina, including 17 bridges in the upper Coastal Plain and 37 in the lower Coastal Plain. Nine of the 54 bridges were old abandoned bridges or railroad bridges near the primary bridge of interest. Scour depths for the most likely scour measurements ranged from 0 to $17.1 \mathrm{ft}$ with a median value of $4.6 \mathrm{ft}$ (table 5). The worst-case estimate of the scour depths ranged from 2.7 to $17.1 \mathrm{ft}$ with a median value of $5.4 \mathrm{ft}$. Approach channel widths ranged from 21 to $785 \mathrm{ft}$ with a median width of $92.5 \mathrm{ft}$. The median size of the channel bed materials ranged from 0.18 to $1.7 \mathrm{~mm}$ with a median of $0.59 \mathrm{~mm}$. Values for 
Table 5. Range of selected characteristics for 54 measurements of live-bed contraction scour collected at 54 bridges in the Coastal Plain Physiographic Province of South Carolina.

$\left[\mathrm{mi}^{2}\right.$, square mile; ft/ft, foot per foot; $\mathrm{ft} / \mathrm{s}$, foot per second; ft, foot; $\left(\mathrm{ft}^{3} / \mathrm{s}\right) / \mathrm{ft}$, cubic foot per second per foot; $\mathrm{mm}$, millimeter]

\begin{tabular}{|c|c|c|c|}
\hline Characteristic & $\begin{array}{l}\text { Minimum } \\
\text { value }\end{array}$ & $\begin{array}{c}\text { Median } \\
\text { value }\end{array}$ & $\begin{array}{l}\text { Maximum } \\
\text { value }\end{array}$ \\
\hline Drainage area $\left(\mathrm{mi}^{2}\right)$ & 17.2 & 521 & $9,360^{\mathrm{a}}$ \\
\hline $\begin{array}{l}\text { Channel slope determined } \\
\text { from topographic map } \\
(\mathrm{ft} / \mathrm{ft})\end{array}$ & 0.00007 & 0.00031 & 0.00200 \\
\hline $\begin{array}{l}\text { Average velocity in ap- } \\
\text { proach channel based on } \\
\text { maximum historic flow } \\
(\mathrm{ft} / \mathrm{s})^{\mathrm{b}}\end{array}$ & 1.1 & 2.7 & 7.1 \\
\hline $\begin{array}{l}\text { Average depth in approach } \\
\text { channel based on maxi- } \\
\text { mum historic flow (ft) }{ }^{b}\end{array}$ & 4.7 & 12.45 & 39.0 \\
\hline $\begin{array}{l}\text { Approach channel width } \\
\text { (ft) }\end{array}$ & 21 & 92.5 & 785 \\
\hline $\begin{array}{l}\text { Unit width flow in ap- } \\
\text { proach channel } \\
{\left[\left(\mathrm{ft}^{3} / \mathrm{s}\right) / \mathrm{ft}\right]^{\mathrm{b}}}\end{array}$ & 6.7 & 34.6 & 267.5 \\
\hline Median grain size $(\mathrm{mm})$ & 0.18 & 0.59 & 1.7 \\
\hline $\begin{array}{l}\text { Observed contraction- } \\
\text { scour depth based on } \\
\text { most likely estimate of } \\
\text { scour }(\mathrm{ft})\end{array}$ & 0 & 4.6 & 17.1 \\
\hline $\begin{array}{l}\text { Observed contraction- } \\
\text { scour depth based on } \\
\text { worst-case estimate of } \\
\text { scour }(\mathrm{ft})\end{array}$ & 2.7 & 5.4 & 17.1 \\
\hline
\end{tabular}

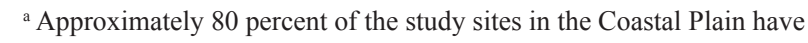
drainage areas less than $1,860 \mathrm{mi}^{2}$ (figure 4).

${ }^{b}$ Values were estimated from the one-dimensional water-surface profile model, WSPRO (Shearman, 1990).

hydraulic data were estimated with the WSPRO model using the maximum historic flows as previously defined.

A total of 35 measurements of live-bed contraction scour were collected at 35 bridge sites in the Piedmont of South Carolina, including 3 bridges in the high-flow region (fig. 2) (Guimaraes and Bohman, 1992). Three of the 35 bridges were old abandoned bridges or another highway bridge near the primary bridge of interest. Scour depths for the most likely scour measurements ranged from 0 to $16.7 \mathrm{ft}$ with a median value of $3.4 \mathrm{ft}$ (table 6). The worst-case estimate of the scour depths ranged from 2.8 to $16.7 \mathrm{ft}$ with a median value of $7.7 \mathrm{ft}$. Approach channel widths ranged from 41 to $788 \mathrm{ft}$ with a median width of $87 \mathrm{ft}$. The median size of the channel bed materials ranged from 0.51 to $1.7 \mathrm{~mm}$ with a median of $0.78 \mathrm{~mm}$. Values for hydraulic data were estimated with the WSPRO model using the maximum historic flows as previously defined.
Table 6. Range of selected characteristics for 35 measurements of live-bed contraction scour collected at 35 bridges in the Piedmont Physiographic Province of South Carolina.

$\left[\mathrm{mi}^{2}\right.$, square mile; $\mathrm{ft} / \mathrm{ft}$, foot per foot; $\mathrm{ft} / \mathrm{s}$, foot per second; $\mathrm{ft}$, foot; $\left(\mathrm{ft}^{3} / \mathrm{s}\right) / \mathrm{ft}$, cubic foot per second per foot; mm, millimeter]

\begin{tabular}{lccc}
\hline \multicolumn{1}{c}{ Characteristic } & $\begin{array}{c}\text { Minimum } \\
\text { value }\end{array}$ & $\begin{array}{c}\text { Median } \\
\text { value }\end{array}$ & $\begin{array}{c}\text { Maximum } \\
\text { value }\end{array}$ \\
\hline $\begin{array}{l}\text { Drainage area }\left(\mathrm{mi}^{2}\right) \\
\text { Channel slope determined } \\
\text { from topographic map } \\
\text { (ft/ft) }\end{array}$ & 0.00015 & 0.00100 & $0.250^{\mathrm{a}}$ \\
\hline $\begin{array}{l}\text { Average velocity in ap- } \\
\text { proach channel based } \\
\text { on maximum historic } \\
\text { flow (ft/s) }\end{array}$ & 2.4 & 5.6 & 11.6 \\
$\begin{array}{l}\text { Average depth in approach } \\
\text { channel based on maxi- } \\
\text { mum historic flow (ft) }{ }^{\mathrm{b}}\end{array}$ & 7.7 & 15.7 & 28.3 \\
\hline $\begin{array}{l}\text { Approach channel width } \\
\text { (ft) }\end{array}$ & 41 & 87 & 788 \\
\hline
\end{tabular}

(ft)

\begin{tabular}{lllr}
$\begin{array}{l}\text { Unit width flow in ap- } \\
\text { proach channel } \\
{\left[\left(\mathrm{ft}^{3} / \mathrm{s}\right) / \mathrm{ft}\right]^{\mathrm{b}}}\end{array}$ & 19.5 & 88.6 & 291.2 \\
$\begin{array}{l}\text { Median grain size }(\mathrm{mm}) \\
\begin{array}{l}\text { Observed contraction- } \\
\text { scour depth based on } \\
\text { most likely estimate of } \\
\text { scour }(\mathrm{ft})\end{array}\end{array}$ & 0.51 & 0.78 & 1.7 \\
$\begin{array}{l}\text { Observed contraction- } \\
\text { scour depth based on } \\
\text { worst-case estimate of } \\
\text { scour (ft) }\end{array}$ & 2.8 & 3.4 & 16.7 \\
\hline
\end{tabular}

a Approximately 94 percent of the study sites in the Piedmont have drainage areas less than $760 \mathrm{mi}^{2}$ (figure 4).

b Values were estimated from the one-dimensional water-surface profile model, WSPRO (Shearman, 1990).

\section{Data Limitations}

In the previous investigations of scour in South Carolina (Benedict, 2003; Benedict and Caldwell, 2006), focus was given to the occurrence of clear-water scour on floodplains. In general, the floodplains of South Carolina are relatively flat and stable, providing a good environment for assessing historic clear-water scour. In particular, the floodplain provides a readily discernable reference surface for determining depths associated with clear-water abutment, contraction, and pier scour. In the case of live-bed bridge scour in the river channel, however, the bed topography is more complex and highly unstable, making it difficult to determine the most appropriate reference surface for estimating the depth of scour. The challenge of selecting a reference surface in a river channel has been noted in other field investigations (Landers and Mueller, 
1993; Mueller and Wagner, 2005; Wagner and others, 2006). The uncertainty associated with selecting the appropriate reference surface for live-bed scour introduces some error into the field measurements for this investigation. In this investigation, the average thalweg elevation was used to estimate a reference surface to determine the live-bed contraction-scour depth. The thalweg, or low point of the channel, should represent the natural conditions of the channel bed with minimal effect from bridge scour. The reference surface can be estimated by plotting the thalweg elevation at selected cross sections along the channel profile and then placing a best-fit line through that data. In certain field situations, the best-fit line may need to be adjusted to better reflect the average thalweg elevation.

In addition to the uncertainty associated with selecting a reference surface, the complex topography of the channel bed can make it difficult to discern which bed features are associated with live-bed contraction scour. Significant changes in the channel-bed topography can be created by various field conditions including confluences (small or large), bends, natural channel constrictions, channel migration, debris, dune bedforms, and the natural thalweg meander (Breusers and Raudkivi, 1991; Melville and Coleman, 2000; Richardson and Davis, 2001). These natural phenomena are typically classified as general scour, and their channel-bed features are similar to those associated with bridge scour. Therefore, when a bridge crosses a stream having field conditions that create general scour, determining which channel-bed features are primarily related to the bridge can be difficult. This can be further complicated when general and bridge scour bed features are concurrent and overlap. In the case of live-bed pier scour, the extent of the scour is relatively small and typically is located near the pier. These characteristics provide a means to more readily identify live-bed pier scour in contrast to general scour. In the case of live-bed contraction scour created by the bridge, however, the extent of the scour can be relatively large and does not necessarily occur at the bridge. These characteristics can make it difficult to determine if the observed scour is created by the bridge, by a natural field condition, or a combination of the two. The complexity and interaction of these scour phenomenon introduce an additional measure of uncertainty and error in estimating live-bed contraction-scour depths in the field.

The uncertainty for estimating live-bed contraction scour is further increased by the subjectivity associated with interpreting the GPR data. The GPR does well in determining the bed topography at the time of the field visit, and the bed topography often identifies the remnants of the historic scour holes that have only been partially refilled (Benedict and others, 2007). However, the determination of the historic scour surfaces that have been refilled with sediments is subjective and at times unclear. As noted previously (see report section "Techniques for the Collection and Interpretation of Field Data"), the GPR data in South Carolina typically show a discernable interface between the sandy river sediments and a subsurface soil layer that often has some resistance to scour (fig. 10). This interface often identifies the historic scour limits. When the existing channel topography identifies a remnant scour hole, and (or) the thickness of the sandy river sediments along the bottom of the scour hole is relatively small (several feet), the estimate of the historic scour depth can be made with more confidence. This pattern is often associated with Coastal Plain streams. However, when the existing channel topography is relatively flat with little evidence of remnant scour holes, and (or) the thickness of the sandy river sediments along the channel is relatively large (over several feet), the estimate of the historic scour depth is less certain. While this pattern can occur in the Coastal Plain, it is found more frequently with Piedmont streams.

In the Coastal Plain, the subsurface soil below the sandy river sediments often is an older marine deposit that has varying degrees of clay and cohesion. The larger scour depths commonly cut into this clayey layer. This same scour pattern was noted by Benedict (2003) in the larger clear-water abutment-scour holes in the Coastal Plain. In the Piedmont, the subsurface layer below the sandy river sediments is often bedrock or decomposed rock with clay that is relatively resistant to scour. The GPR data indicate that while scour may reach this subsurface layer, it is uncommon for scour depths to cut into this rocky, clayey material. A comparison of the relative elevation differences between the bottom of the livebed contraction-scour holes and the scour-resistant subsurface layers as identified in the SCDOT bridge plan borings shows these differing scour patterns (fig. 52). The SCDOT borings typically do not correspond to the same locations as those of the live-bed contraction-scour measurements; therefore, the data are not ideal for the comparison. However, the data are considered sufficient to show the general trends. The estimate of the live-bed contraction-scour depth that is called the "most likely estimate of measured scour" represents the interpreter's judgment of the maximum historic scour that most likely has occurred at that site based on the GPR data (fig. 52A). The pattern shows that scour in the channels of the Coastal Plain frequently cuts into the subsurface layer. In the Piedmont, however, this pattern is less frequent. The Piedmont data indicate that some scour holes cut into the rocky, clayey subsurface layers. However, this seems improbable and the pattern likely can be associated with the non-concurrent location of the SCDOT borings and scour measurements, as well as the error associated with the GPR interpretation. With this in mind, the pattern in figure $52 \mathrm{~A}$ indicates that the scour depths for the Piedmont essentially do not exceed the subsurface layer. The estimate of the live-bed contraction-scour depth that is called the "worst-case estimate of measured scour," was used in fig. 52B, and at sites where the GPR data are ambiguous, scour is assumed to be cut down to and stopped at the subsurface layer. In many cases, the most likely and worst-case estimate of scour were the same. At some sites (mostly in the Piedmont), the most likely and worst-case values significantly differed. On the vertical axis of figure $52 \mathrm{~A}$, many sites have contraction-scour depths of $0 \mathrm{ft}$ for the most likely estimate of measured live-bed contraction scour. The worst-case estimate of measured scour typically was based on the depth to the 


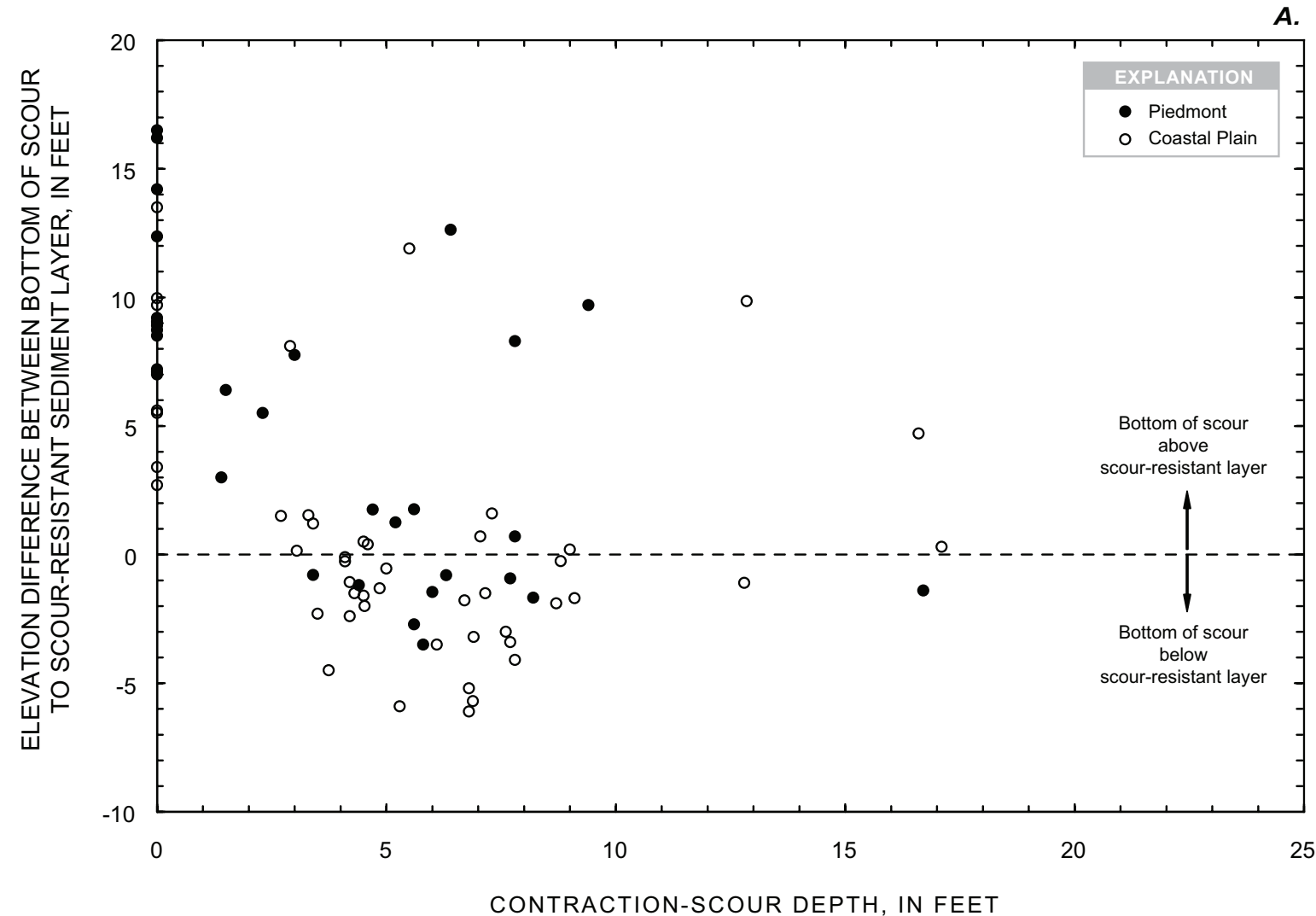

B.

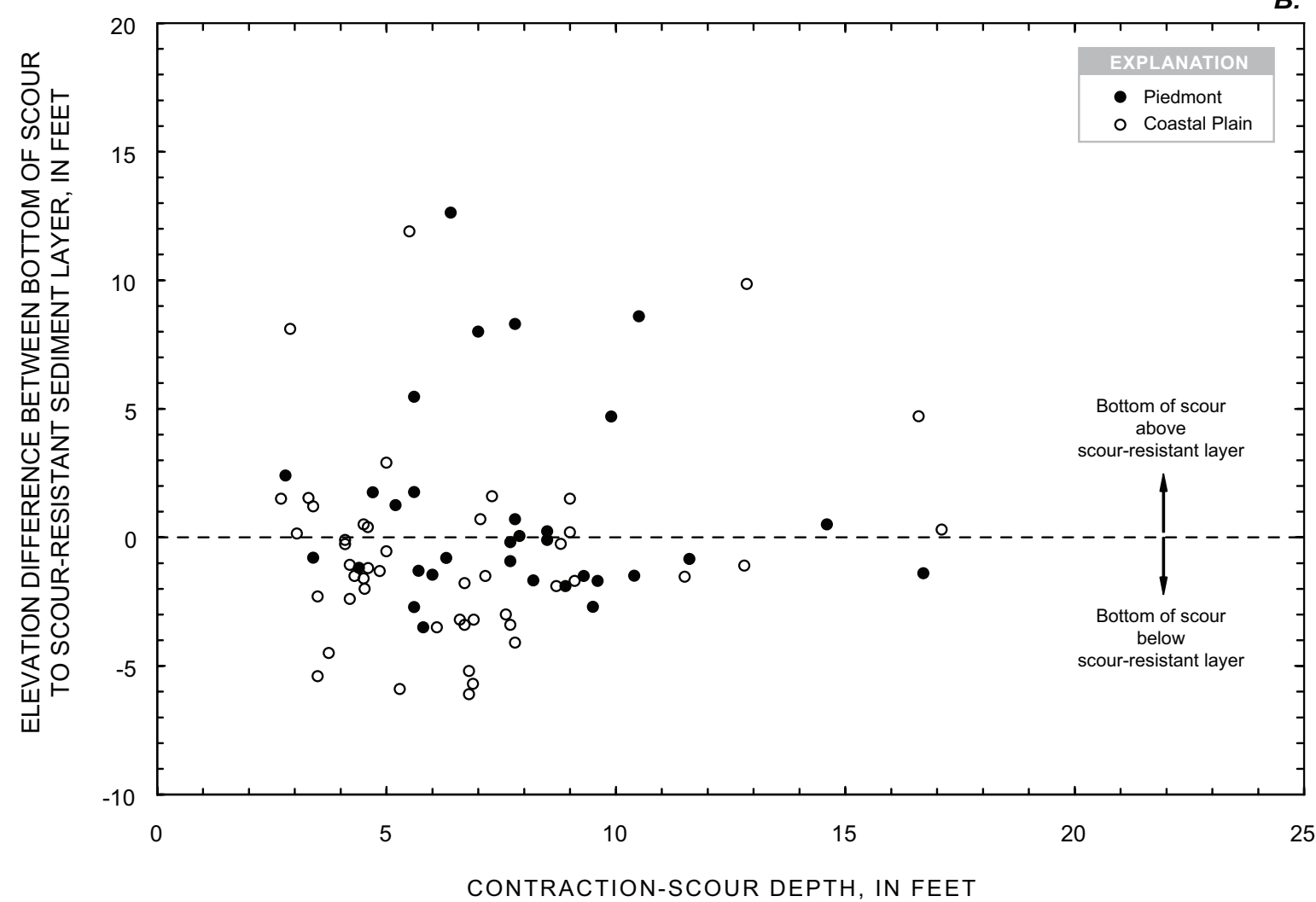

Figure 52. Relation of elevation difference between the bottom of live-bed contraction-scour hole and the scour-resistant subsurface layer to $(A)$ the most likely estimate of the measured live-bed contraction-scour depth, and $(B)$ the worst-case estimate of the measured live-bed contraction-scour depth at selected sites in South Carolina. 
subsurface layer, as can be seen in figure $52 B$, where many of the data points from figure $52 A$ have shifted to a location near the location of the subsurface layer. The scour measurements for the most likely estimate of measured scour (or most likely scour) are considered to be the best estimate and will be the primary data used in the analysis.

The complexities associated with assessing live-bed contraction scour in conjunction with the subjectivity of the GPR interpretations introduces uncertainty and error into the live-bed contraction-scour estimates for this investigation. These limitations should be kept in mind when assessing the trends associated with these data.

\section{Other Sources of Field Data}

In a review of the published literature, Mueller and Wagner (2005) and Wagner and others (2006) found limited field measurements of live-bed contraction scour. Several sources identified in these previous investigations include the USGS National Bridge Scour Database (NBSD; U.S. Geological Survey, 2001) and data published in Hayes (1996). Data from these sources were used to supplement the current investigation (2009) to help assess the validity of the trends observed in the South Carolina field data. The NBSD includes 15 measurements of live-bed contraction scour; however, 6 measurements had insufficient hydraulic and (or) supplementary data and were excluded from this analysis. The nine NBSD measurements included in this analysis were taken at seven bridge sites located in five States (Alaska, Iowa, Minnesota, Mississippi, and South Dakota). These data have similar median grain sizes to those of the South Carolina field data, having a range from 0.1 to $1.6 \mathrm{~mm}$. Drainage areas also are similar, ranging from 10.3 to $16,010 \mathrm{mi}^{2}$. Live-bed contraction-scour depths for the selected NBSD data range from 0 to $15 \mathrm{ft}$, and eight of the measurements are associated with floods that were near to or exceeded the 100-year flow magnitude. Some of the nine NBSD measurements used in the analysis have missing supplementary and (or) hydraulic data, which limits their use in certain parts of this analysis. Based on these selected relations, not all of the NBSD data could be used. The selected field data from Hayes (1996) included 14 measurements of live-bed contraction scour collected at the same bridge site (Pamunkey River near Hanover, Virginia), with a median sediment size of $0.7 \mathrm{~mm}$ and a drainage area of 1,078 $\mathrm{mi}^{2}$. Because the data were collected at the same bridge site, only the three largest measurements were used for comparison in this investigation. Live-bed contractionscour depths for these three measurements ranged from 6.9 to $7.4 \mathrm{ft}$, and the associated flows ranged from approximately 50 to 60 percent of the 100-year flow magnitude. Hydraulic data for the NBSD and Hayes (1996) scour measurements were primarily based on flow measurements at the time of the scour measurement. In some cases, a one-dimensional flow model calibrated to the measured flow was used to estimate hydraulic variables at the approach cross section. Table 7 lists the range of selected characteristics associated with the NBSD and Hayes (1996) data used in this (2009) investigation.
Table 7. Range of selected characteristics for 12 measurements of live-bed contraction scour collected at 8 bridges in the National Bridge Scour Database and from Hayes (1996).

$\left[\mathrm{mi}^{2}\right.$, square mile; $\mathrm{ft} / \mathrm{s}$, foot per second; $\mathrm{ft}$, foot; $\left(\mathrm{ft}^{3} / \mathrm{s}\right) / \mathrm{ft}$, cubic foot per second per foot; mm, millimeter]

\begin{tabular}{|c|c|c|c|}
\hline Characteristic & $\begin{array}{l}\text { Minimum } \\
\text { value }\end{array}$ & $\begin{array}{l}\text { Median } \\
\text { value }\end{array}$ & $\begin{array}{l}\text { Maximum } \\
\text { value }\end{array}$ \\
\hline Drainage area $\left(\mathrm{mi}^{2}\right)$ & 10.3 & 1,078 & 16,010 \\
\hline $\begin{array}{l}\text { Average velocity in approach } \\
\text { channel associated with mea- } \\
\text { sured scour }(\mathrm{ft} / \mathrm{s})^{\mathrm{a}}\end{array}$ & 0.7 & 3.4 & 5.2 \\
\hline $\begin{array}{l}\text { Average depth in approach chan- } \\
\text { nel associated with measured } \\
\text { scour }(\mathrm{ft})^{\text {a }}\end{array}$ & 7.9 & 22.6 & 43 \\
\hline Approach channel width (ft) & 42 & 150 & 300 \\
\hline $\begin{array}{l}\text { Unit width flow in approach } \\
\text { channel associated with mea- } \\
\text { sured scour }\left[\left(\mathrm{ft}^{3} / \mathrm{s}\right) / \mathrm{ft}\right]^{\text {a }}\end{array}$ & 25.7 & 120.7 & 242.9 \\
\hline Median grain size (mm) & 0.1 & 0.3 & 1.6 \\
\hline $\begin{array}{l}\text { Observed contraction-scour } \\
\text { depth (ft) }\end{array}$ & 0 & 7 & 15 \\
\hline
\end{tabular}

${ }^{a}$ Values were estimated from discharge measurements and one-dimensional flow models using flows associated with measured scour.

(Note: Hayes [1996] published a geometric-contraction ratio of 0.29 for the live-bed contraction-scour data collected at the Pamunkey River site. This value represents the contraction created by the bridge and was determined from the WSPRO [Shearman, 1990] model. To estimate the geometriccontraction ratio, the WSPRO model uses a standard location of the approach cross section at one bridge length upstream from the bridge. However, the bridge at the Pamunkey River site is located in a natural contraction that begins beyond the standard location of the approach cross section, and the natural contraction has a geometric-contraction ratio of approximately 0.9. Based on this field condition, it is reasonable to expect that the combined effect of the natural constriction and the bridge will create a more severe geometric-contraction ratio than the WSPRO value of 0.29 . Therefore, for the purposes of this investigation, the average geometric-contraction ratio of 0.6 was used to approximate the contraction conditions at this site.)

In addition to the NBSD and Hayes (1996) data, 42 measurements of clear-water contraction scour selected from the previous field investigation of clear-water scour in South Carolina (Benedict, 2003) were used to help verify the trends in the live-bed contraction-scour measurements. The selected clear-water data are associated with shorter bridges (approximately $240 \mathrm{ft}$ or less in length) that typically create large contractions of flow and often have significant scour. These sites include floodplain relief bridges and bridges crossing swamps with poorly defined channels. These bridges typically develop a large single scour hole with a top width that often encompasses the entire bridge opening (figs. 53 and 54). The 


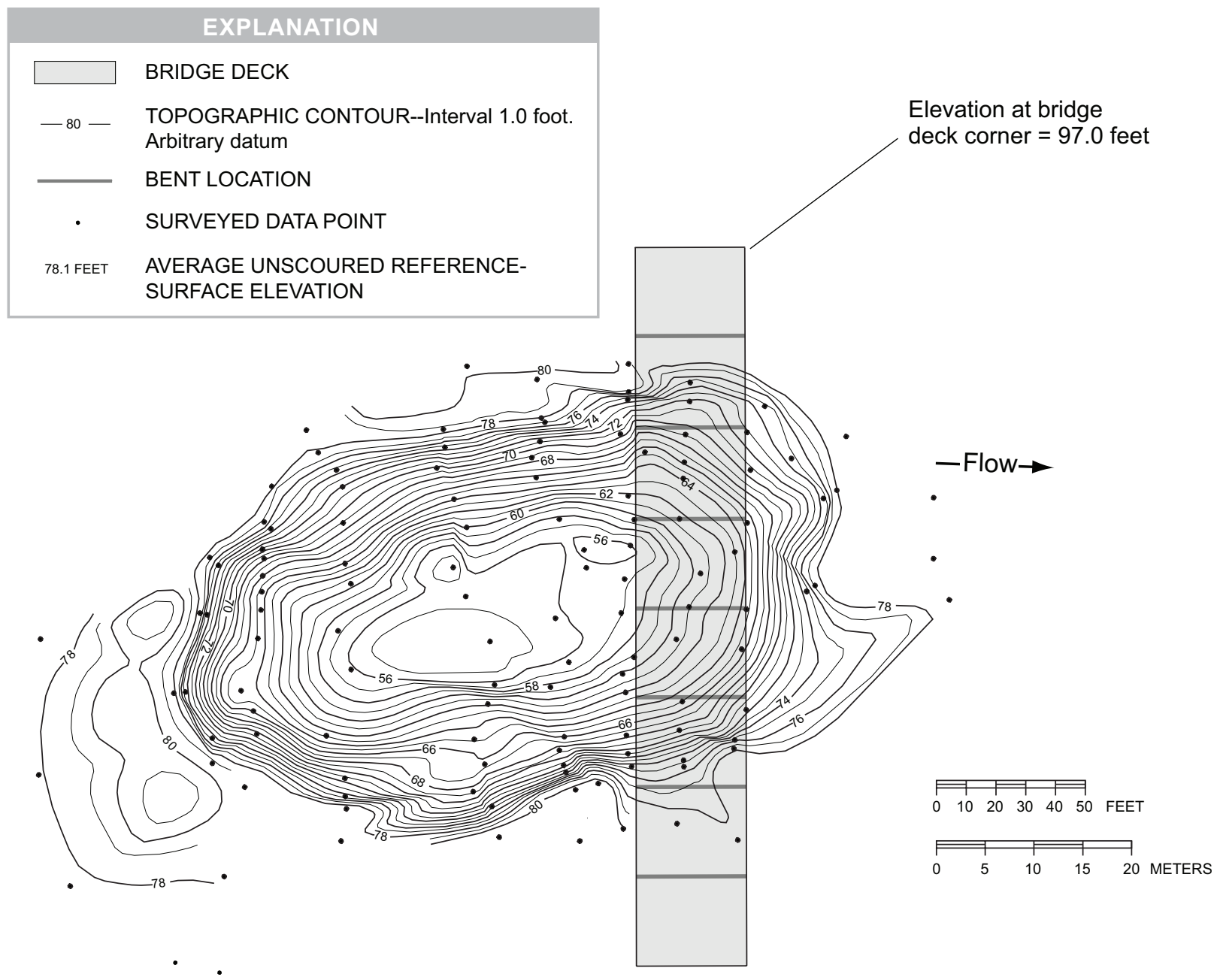

Figure 53. Example of clear-water contraction scour created by a severe contraction at structure 211009511400 on Interstate 95, crossing the Pee Dee River floodplain in Florence County, South Carolina, August 19, 1996 (from Benedict, 2003).

severe contractions associated with these bridges significantly increase flow velocities at the bridge and tend to create turbulent flow patterns similar to abutment scour. Because of the similarity of flow patterns to those for abutment scour, Benedict (2003) considered these data as special cases of clearwater abutment scour. However, because of the short bridge lengths and the large contractions created by these bridges, it is also appropriate to consider these data as cases of severe clear-water contraction scour, which is how the data were classified for the current investigation (2009). The selected South Carolina clear-water contraction-scour data have similar median grain sizes to those of the live-bed data, having a range from 0.06 to $0.78 \mathrm{~mm}$. Drainage areas range from 6.1 to $8,230 \mathrm{mi}^{2}$ (table 8 ), but data are primarily associated with smaller drainage areas less than $265 \mathrm{mi}^{2}$. The clear-water contraction-scour depths for the selected South Carolina data range from 0.9 to $23.6 \mathrm{ft}$, and most sites likely have experienced floods equaling or exceeding 70 percent of the 100 -year flow magnitude (Benedict, 2003). Values for hydraulic data were estimated with the WSPRO model using the 100-year flow magnitude to approximate the flow conditions that may have created the observed scour.

Because researchers have traditionally separated the analyses of clear-water and live-bed scour, the combining of live-bed and clear-water contraction-scour data in this analysis initially may seem inappropriate. However, if the purpose of this study is to understand the upper bound of contraction scour on a regional basis, making some comparisons with these data is appropriate. Some justification for this approach can be found in laboratory data. Gill (1981) conducted a laboratory investigation of scour at a long contraction, collecting 26 live-bed and 19 clear-water contraction-scour measurements. Sorting the laboratory data by sediment size, contraction ratio, and similar flow rates and comparing the live-bed and clear-water data indicate that the upper bounds for both types of scour are similar. This laboratory trend indicates that 


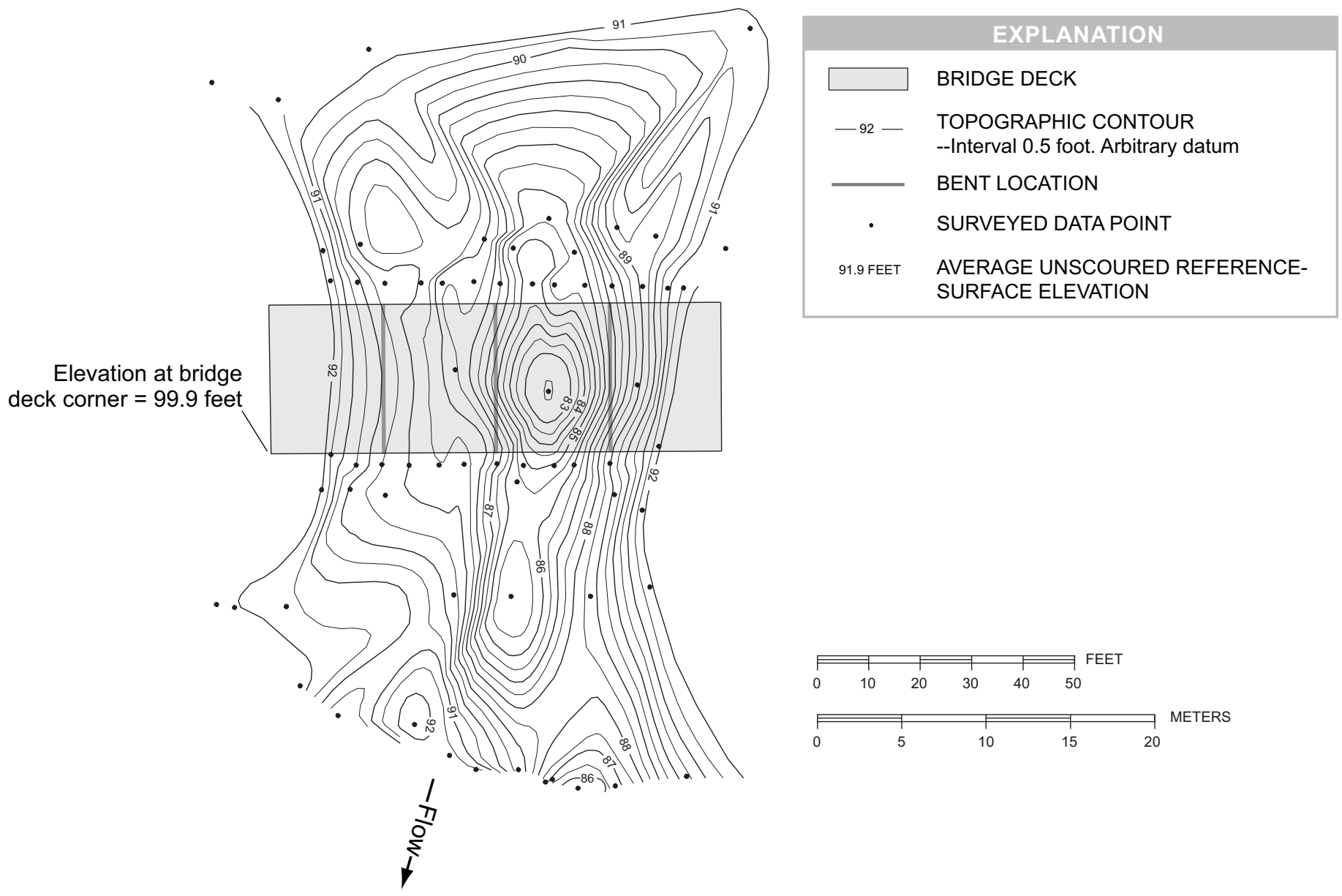

Figure 54. Example of clear-water contraction scour created by severe contraction at structure 212030100100 on U.S. Route 301, crossing Douglas Swamp in Florence County, South Carolina, July 31, 1996 (from Benedict, 2003).

on a regional basis, where sediments and flow rates would be similar, the upper bounds of live-bed and clear-water contraction scour likely will be similar. A comparison of the average velocities in the contracted sections for the South Carolina live-bed and the selected clear-water contraction-scour data indicates that the ranges and medians are similar. For the South Carolina live-bed contraction-scour data, the velocity in the contracted channel ranges from 1.2 to $10.5 \mathrm{ft} / \mathrm{s}$ with a median value of $4.8 \mathrm{ft} / \mathrm{s}$. For the selected South Carolina clear-water contraction-scour data, the velocity in the contracted channel ranges from 1.8 to $10.0 \mathrm{ft} / \mathrm{s}$ with a median value of $5.2 \mathrm{ft} / \mathrm{s}$. The flow similarity, in conjunction with grain-size similarity for the South Carolina live-bed and clear-water contraction-scour data, indicates regional similarity. This result suggests that the upper bound of the contraction-scour depths for these datasets will be similar and could be combined to help assess the upper bound of contraction scour in South Carolina. While these datasets have some differences, the general trends of the clear-water contraction-scour data should be similar to the live-bed scour data, providing a means to help validate the trends of the livebed contraction-scour data.
To provide some perspective on how the sets of live-bed contraction-scour data compare with each other, figure 55 shows the relation of geometric-contraction ratio to live-bed contraction-scour depth for the NBSD, Hayes (1996), and South Carolina live-bed contraction-scour data. (The South Carolina clear-water contraction-scour data [Benedict, 2003] are not included in this figure but will be discussed later in the report.) Although the number of measurements in the NBSD and Hayes (1996) data are limited, they do fall within the range of the South Carolina data, indicating that the range of the South Carolina data likely is reasonable.

\section{Comparison of Measured and Predicted Contraction-Scour Depths Using the HEC-18 Equation}

To predict potential contraction-scour depths for livebed scour conditions, HEC-18 (Richardson and Davis, 2001) recommends the use of a modified version of Laursen's (1960) equation (eq. 3). The Laursen (1960) live-bed 
Table 8. Range of selected characteristics for 42 measurements of clear-water contraction scour created by severe contractions collected at 40 bridges in the Coastal Plain Physiographic Province and 2 bridges in the Piedmont Physiographic Province of South Carolina.

$\left[\mathrm{mi}^{2}\right.$, square mile; $\mathrm{ft} / \mathrm{ft}$, foot per foot; $\mathrm{ft} / \mathrm{s}$, foot per second; $\mathrm{ft}$, feet; $(\mathrm{ft} / \mathrm{s}) / \mathrm{ft}$, cubic foot per second per foot; mm, millimeter]

\begin{tabular}{|c|c|c|c|}
\hline Characteristic & $\begin{array}{l}\text { Minimum } \\
\text { value }\end{array}$ & $\begin{array}{l}\text { Median } \\
\text { value }\end{array}$ & $\begin{array}{l}\text { Maximum } \\
\text { value }\end{array}$ \\
\hline Drainage area $\left(\mathrm{mi}^{2}\right)$ & 6.1 & 32.2 & $8,230^{\mathrm{a}}$ \\
\hline $\begin{array}{l}\text { Channel slope determined } \\
\text { from topographic map } \\
(\mathrm{ft} / \mathrm{ft})\end{array}$ & 0.00015 & 0.00100 & 0.00210 \\
\hline $\begin{array}{l}\text { Average velocity in ap- } \\
\text { proach floodplain based } \\
\text { on the } 100 \text {-year flow } \\
(\mathrm{ft} / \mathrm{s})^{\mathrm{b}}\end{array}$ & 0.05 & 0.5 & 0.94 \\
\hline $\begin{array}{l}\text { Average depth in approach } \\
\text { floodplain based on the } \\
100 \text {-year flow (ft) }{ }^{b}\end{array}$ & 2 & 4.3 & 11.7 \\
\hline $\begin{array}{l}\text { Unit width flow in approach } \\
\text { floodplain based on the } \\
100 \text {-year flow }\left[\left(\mathrm{ft}^{3} / \mathrm{s}\right) / \mathrm{ft}\right]^{\mathrm{b}}\end{array}$ & 0.4 & 2.1 & 6.3 \\
\hline Median grain size (mm) & 0.06 & 0.2 & 0.78 \\
\hline $\begin{array}{l}\text { Observed contraction-scour } \\
\text { depth (ft) }\end{array}$ & 0.9 & 9.6 & 23.6 \\
\hline
\end{tabular}

${ }^{a}$ Approximately 95 percent of the clear-water sites have drainage areas less than $265 \mathrm{mi}^{2}$ (Benedict, 2003).

b Values were estimated from the one-dimensional water-surface profile model, WSPRO (Shearman, 1990).

contraction-scour equation was analytically derived for a simple long contraction in a rectangular channel. The original Laursen (1960) equation is identical to the HEC-18 equation (Richardson and Davis, 2001), but includes a term to account for changes in roughness coefficients between the approach and contracted sections. Laursen (1960) notes that this term will usually be close to a value of one and can be omitted as is the recommendation in HEC-18 (Richardson and Davis, 2001). The application of the Laursen (1960) equation to a bridge setting can, in general, be difficult, especially when abutments are set back from the main channel (Melville and Coleman, 2000; Richardson and Davis, 2001). All of the South Carolina live-bed contraction-scour data are associated with setback abutments, indicating that the application of the equation may be beyond the scope of its original design.

The relation of measured to predicted live-bed contraction-scour depths for the South Carolina, NBSD, and Hayes (1996) data is shown in figure 56. (Note: The 10 South Carolina field measurements collected at abandoned highway bridges and railroad bridges and 3 NBSD measurements were not included because sufficient data for calculating predicted scour were not available.) The two interpretations of the South Carolina GPR field data, the most likely estimate and worst-case estimate of measured scour, are represented in figures $56 A$ and $56 B$, respectively. Predicted scour was calculated using the maximum historic flows for the South Carolina data and the measured flows for the NBSD and Hayes (1996) data. A large scatter around the line of agreement indicates a significant difference between the predicted and measured scour. The error associated with the South Carolina field data and the estimated hydraulics from one-dimensional flow models likely account for some of the prediction error in figure 56. However, the limited field data from the NBSD has a similar trend to that of the South Carolina data, indicating that the scatter, in part, is associated with the equation.

A review of the relation between the prediction error (predicted scour minus measured scour) and variables from equation 3 shows that the scatter of the under and overprediction is fairly well distributed around the prediction error of zero (fig. 57). This indicates that the HEC-18 equation (Richardson and Davis, 2001) tends to capture the average trend through the field data rather than the upper bound of the data.

The flow and width ratios $\left(Q_{2} / Q_{1}\right.$ and $W_{1} / W_{2}$, respectively, as defined in equation 3 ) for the field data are at times less than a value of one (fig. 57). When these ratios are less than one and applied to equation 3 , they will tend to reduce predicted scour and occasionally produce negative scour depths. To minimize underprediction with the live-bed contractionscour equation (eq. 3), the flow and width ratios can be limited so that ratios less than one are rounded up to a value of one. This modification was applied to the data in figure $57 \mathrm{~A}$ and results are displayed in figure 58. (Note: The field data for the most likely estimate of live-bed contraction-scour depth are probably the more reasonable data; therefore, these will be the primary data used for the remainder of the report.) The effect of the applied modification is to increase predicted scour at those sites where the flow and (or) width ratios were rounded up to a value of one. Overall, the number of overpredictions is increased, the number of underpredictions is reduced, and all negative estimates of scour depth are eliminated. The prediction error associated with the modification is plotted in figure 59 in the same manner as in figure 57. The relation between the $W_{1} / W_{2}$ ratio and the prediction error (fig. 59B) still indicates that there is not a strong relation between the error and this equation variable. However, the relation between the $Q_{2} / Q_{1}$ ratio and the prediction error (fig. $59 \mathrm{~A}$ ) is more defined with the modified ratios, indicating that some error may be associated with this variable.

The significant scatter and frequent underprediction associated with the live-bed contraction-scour equation (Richardson and Davis, 2001; eq. 3; figs. 56 and 58) suggest that the equation is a poor predictor for scour at Coastal Plain and Piedmont sites and that additional methods are needed to assist the practitioner in evaluating live-bed contraction scour in these regions. In the previous investigations of clear-water scour, envelope curves of field data were found to be useful tools for assisting in the evaluation of scour potential. The 


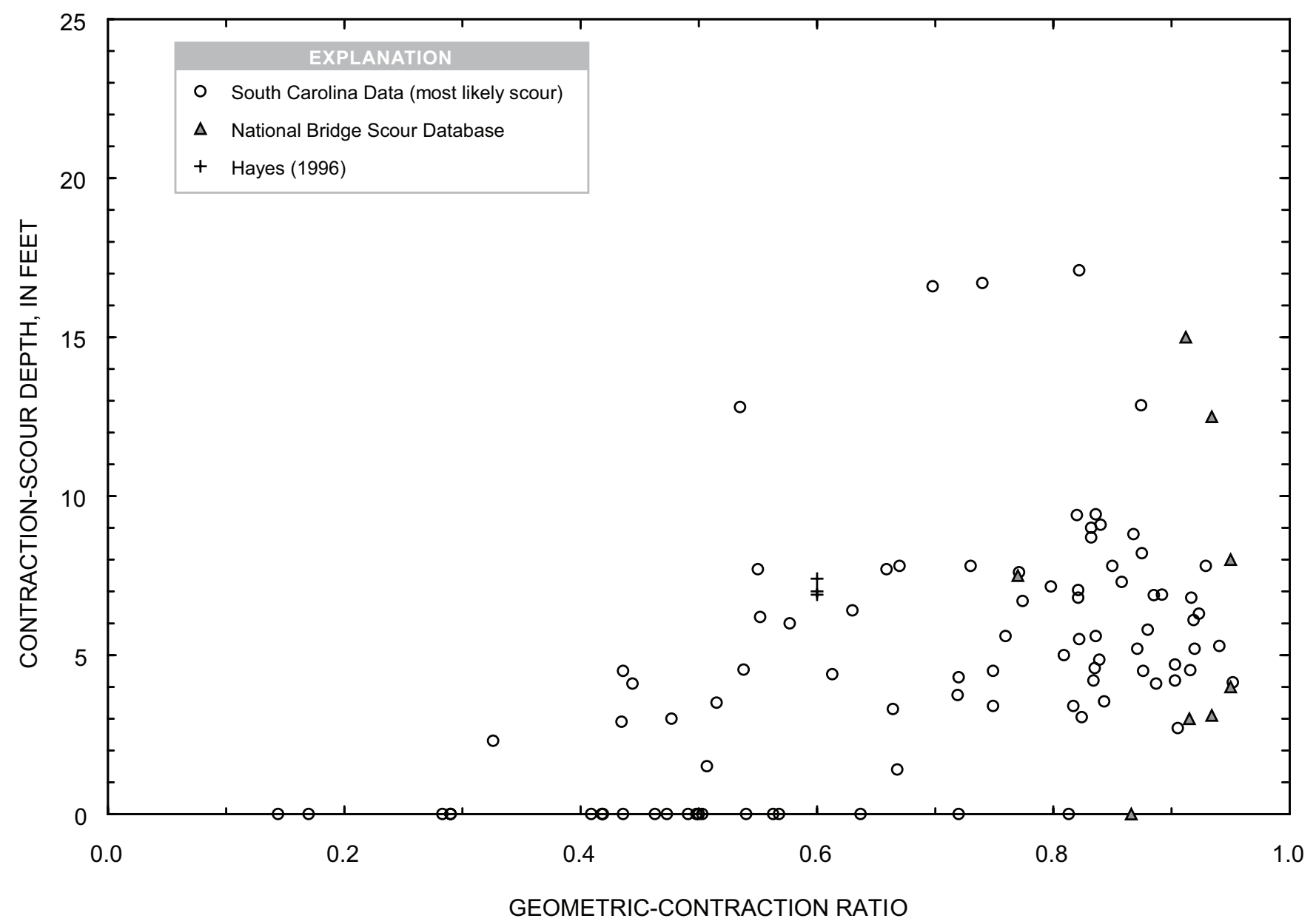

Figure 55. Relation of measured live-bed contraction-scour depth and the geometric-contraction ratio for selected field data.

following sections of the report contain reviews of several envelope curves to assist in evaluating live-bed contraction scour in South Carolina.

\section{Dimensionless Envelope Curves for Live-Bed Contraction Scour}

The modified Laursen (1960) equation in HEC-18 (Richardson and Davis, 2001) can be presented in a graphical form that shows theoretical envelope curves associated with the dimensionless variables in the equation. By rearranging equations 3 and 4, the following equation can be obtained:

$$
\frac{y_{s}}{y_{1}}=\left[\frac{Q_{2}}{Q_{1}}\right]^{6 / 7}\left[\frac{W_{1}}{W_{2}}\right]^{k_{1}}-1,
$$

where all variables are as previously defined. (Note: The $k_{1}$ exponent was assumed to be the average value of 0.64.) Theoretical envelope curves can be developed from equation 9 by arbitrarily setting the channel width ratio $\left(W_{1} / W_{2}\right)$ to a constant and varying the channel flow ratio $\left(Q_{2} / Q_{1}\right)$ to compute theoretical values of the dimensionless variable $y_{s} / y_{1}$. Figure 60 shows selected theoretical envelope curves for equation 9 for channel width ratios $\left(W_{1} / W_{2}\right)$ of 1 and 1.5. The width ratios were selected based on the range of the field data (greater than 0.5 and less than 1.5) as displayed in figure $57 B$. The vertical axis in figure 60 represents scour depth normalized by the approach channel flow depth $\left(y_{s} / y_{1}\right)$, and the horizontal axis represents the channel flow ratio $\left(Q_{2} / Q_{1}\right)$ as defined in the modified Laursen (1960) equation (Richardson and Davis, 2001; eq. 3). Along with the theoretical envelope curves, figure 60 shows dimensionless variables determined for the South Carolina and NBSD field data that correspond to the theoretical envelope curves. (Note: The Hayes [1996] data were not included because of insufficient supporting information.) The data indicate that field sites with width ratios greater than 1 have a higher upper bound for the dimensionless scour than do those with width ratios 1 or less, therefore, conforming in some measure to the expected trends of the modified Laursen (1960) equation (Richardson and Davis, 2001). Additionally, the upper bound of the data increases as the channel 
A.

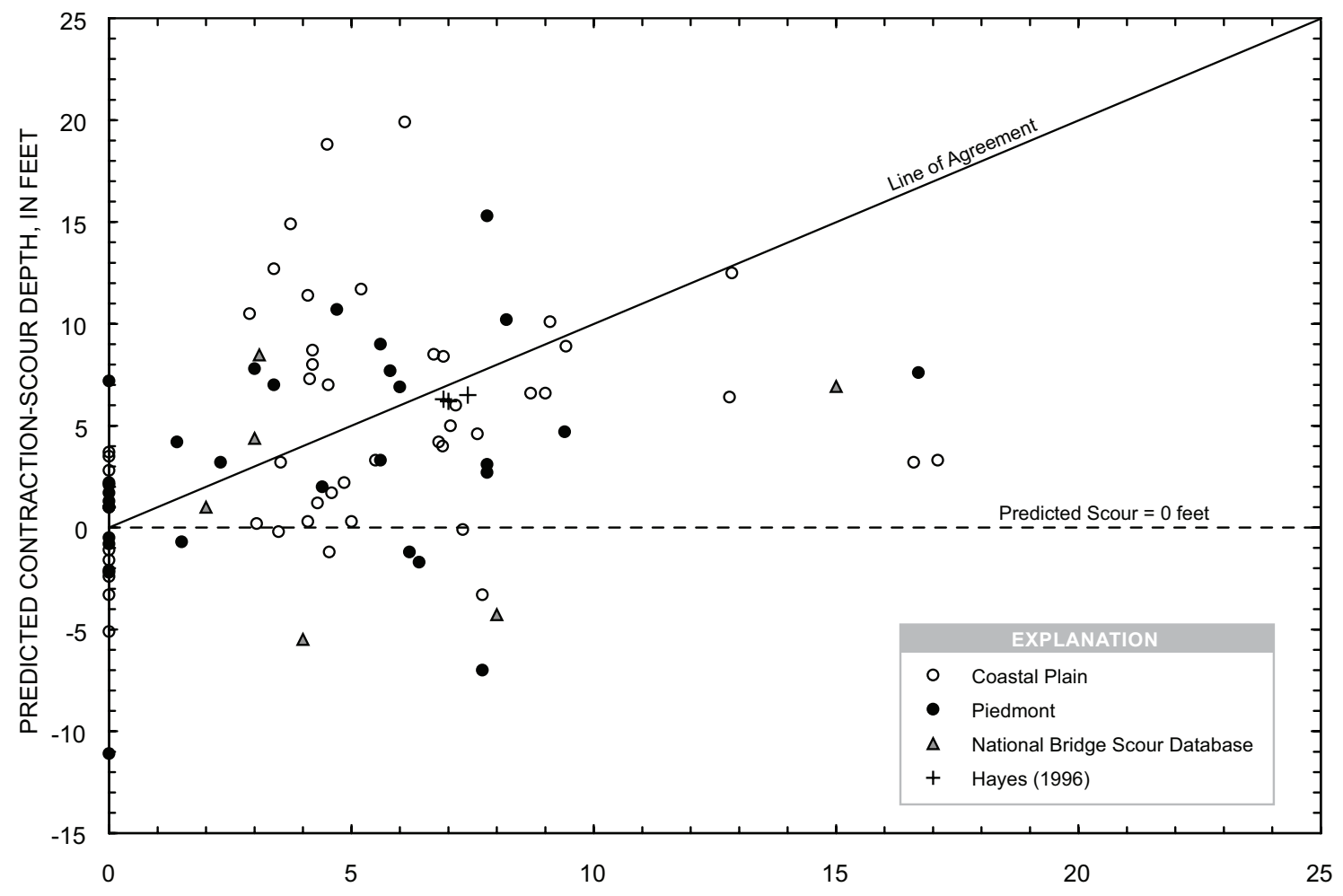

MEASURED CONTRACTION-SCOUR DEPTH, IN FEET

B.

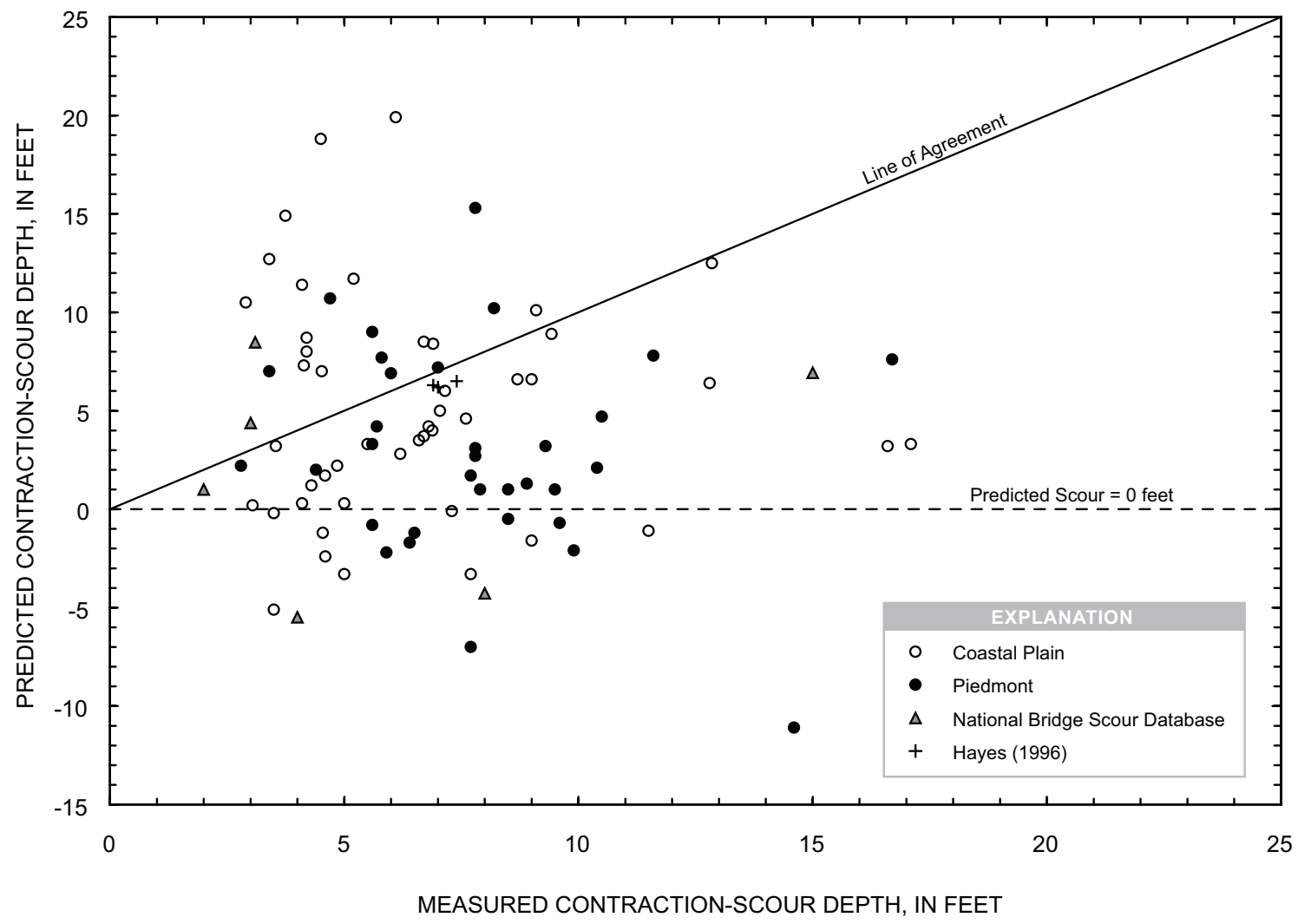

Figure 56. Relation of measured to predicted live-bed contraction-scour depth for $(A)$ the most likely estimate of measured scour, and $(B)$ the worst-case estimate of measured scour at selected sites in South Carolina and selected data from the National Bridge Scour Database and Hayes (1996). [Predicted contraction scour calculated with the modified Laursen equation (Richardson and Davis, 2001).] 

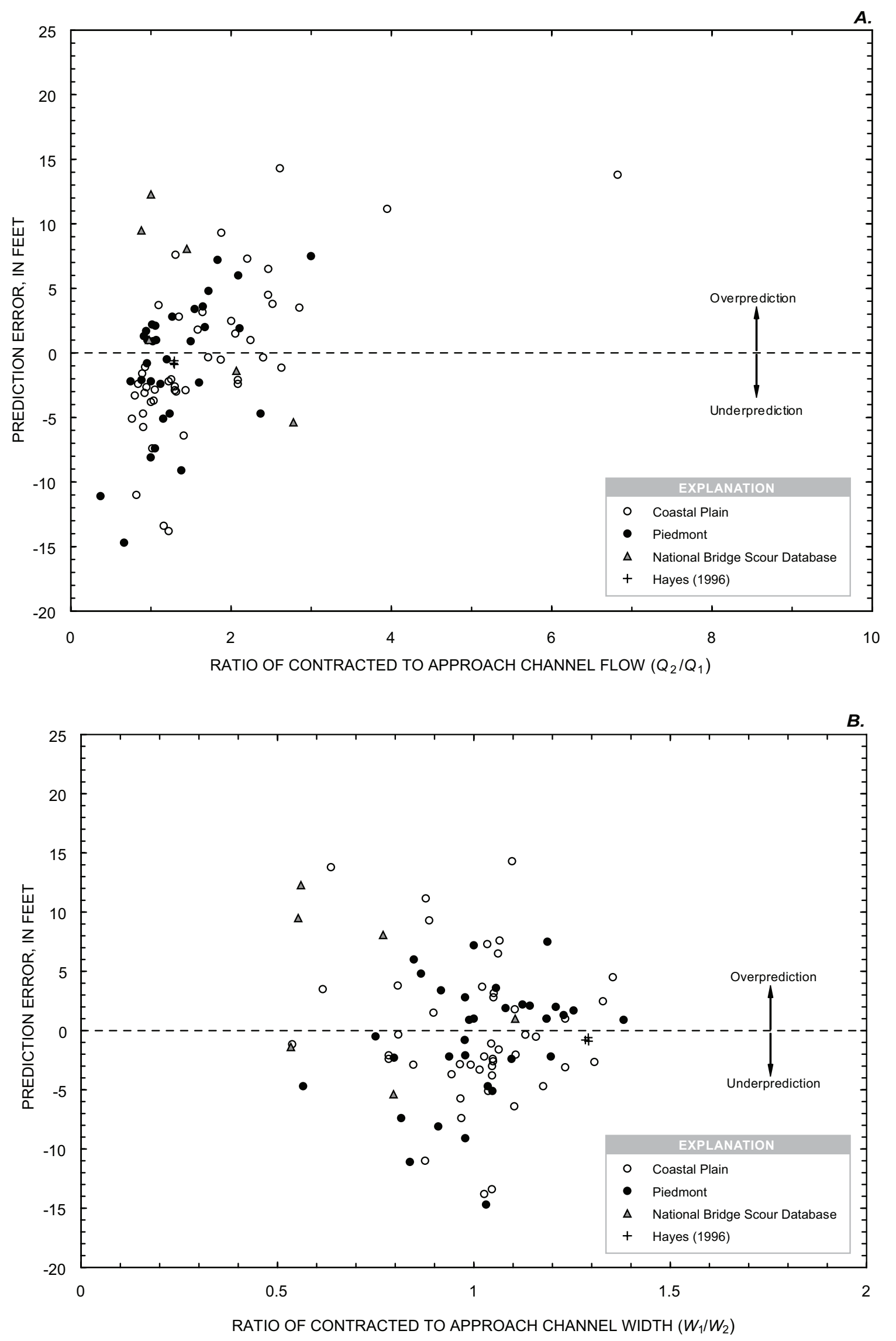

Figure 57. Relation of prediction error for live-bed contractionscour depth to $(A)$ the ratio of contracted to approach channel flow $\left(Q_{2} / Q_{1}\right)$, and $(B)$ the ratio of approach to contracted channel width $\left(W_{1} / W_{2}\right)$, at selected sites in South Carolina and selected data from the National Bridge Scour Database and Hayes (1996). [Prediction error was determined by subtracting the most likely estimate of measured scour from the predicted scour calculated with the modified Laursen equation (Richardson and Davis, 2001).] 


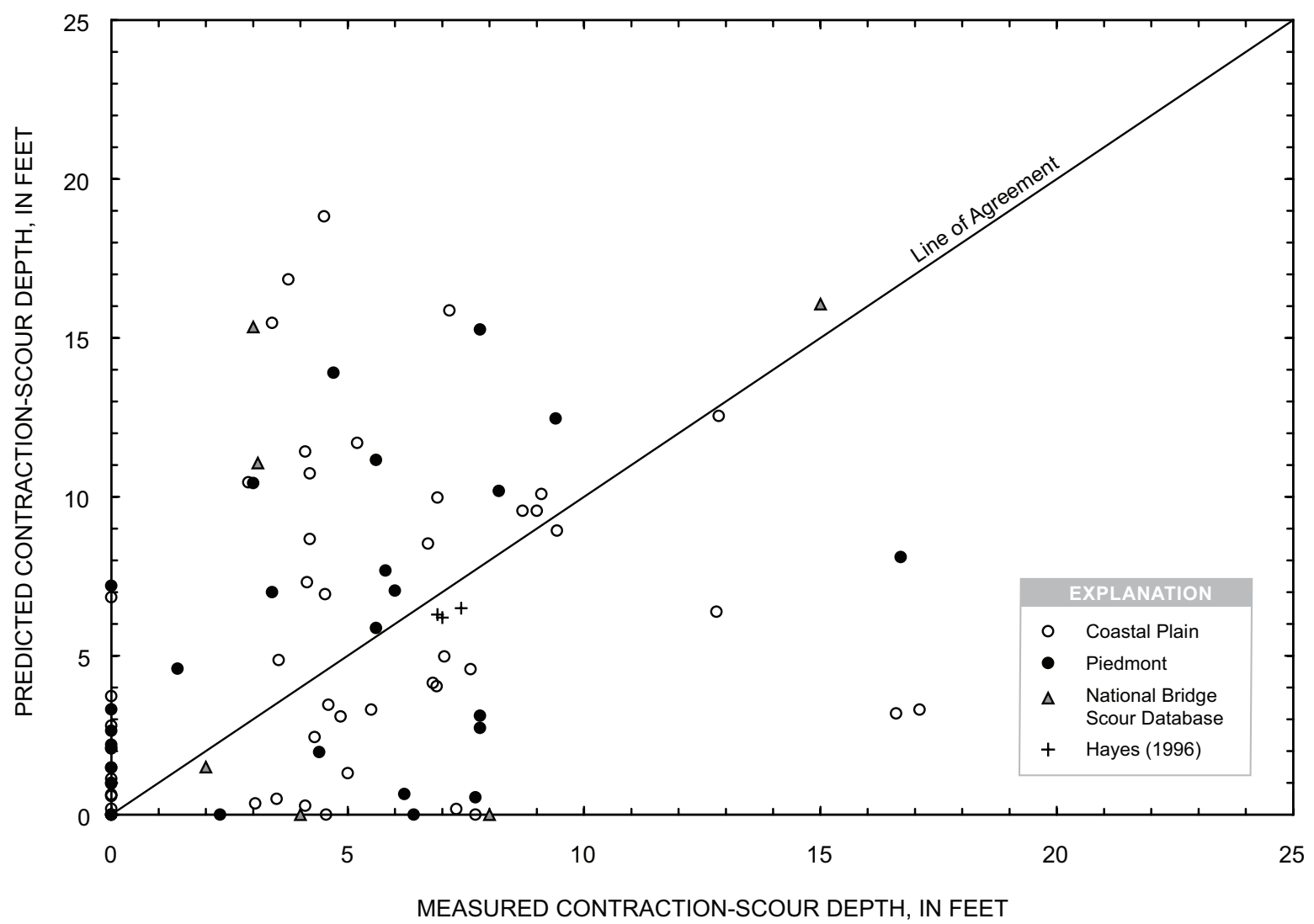

Figure 58. Relation of measured to predicted live-bed contraction-scour depth at selected sites in South Carolina and selected data from the National Bridge Scour Database and Hayes (1996). [Predicted contraction scour was calculated with the modified Laursen equation (Richardson and Davis, 2001) and with the limitation that the flow and width ratios be rounded up to a value of 1 if they are less than 1.]

flow ratio increases, which is consistent with the expected equation trends. The rate of increase in the upper bound of the field data is not as steep as the equation envelope curves, however, and at lower values of the channel flow ratio, a number of data points exceed the curves, indicating that the equation will underpredict at those sites. The field data begin to exceed the equation envelope curves at sites with channel flow ratios of about 2 or less. When using the modified Laursen (1960) equation (Richardson and Davis, 2001) at sites having a width ratio less than 1.5 and a channel flow ratio less than 2 , it may be prudent to set the channel flow ratio to a value of 2 to minimize underprediction.

All field data are shown in figure 61 in a similar manner to that of figure 60 . It is interesting to note that the upper bound of the Coastal Plain data exceeds that of the Piedmont. The reason for this trend is uncertain; however, the differing field characteristics between these regions may account for this, in part. The Coastal Plain tends to have longer flow durations, more severe bridge flow contractions, and subsurface layers that are more susceptible to scour than the Piedmont. These characteristics tend to produce the larger dimensionless scour depths in the Coastal Plain. Another factor that may contribute to the larger dimensionless scour depths in the Coastal Plain is the lower flow depths in that region. The relation of live-bed contraction-scour depth to approach channel flow depth indicates that the Coastal Plain flow depths tend to be smaller than those of the Piedmont (fig. 62). Under these trends, for the same live-bed contraction-scour depth, the Coastal Plain tends to produce a larger dimensionless scour depth than does the Piedmont, giving some explanation for the trend shown in figure 61. Envelope curves of the dimensionless field data can be drawn for the Coastal Plain and Piedmont of South Carolina (fig. 63). These dimensionless envelope curves and their associated equations can be used to help assess live-bed contraction-scour potential in the Coastal Plain and Piedmont of South Carolina. The application of these curves should be used with caution and limited to sites well within the range of the data used to develop the dimensionless envelope curves.

It is possible to apply the modified Laursen (1960) equation (Richardson and Davis, 2001) to a bridge contraction by assuming the approach and bridge cross sections can be approximated as simple rectangular channels. Under this simplifying assumption, the flow in the approach channel and at the bridge will be equal to the total flow, and the channel flow ratio will be equal to 1. (Note: For a multiple bridge crossing, 

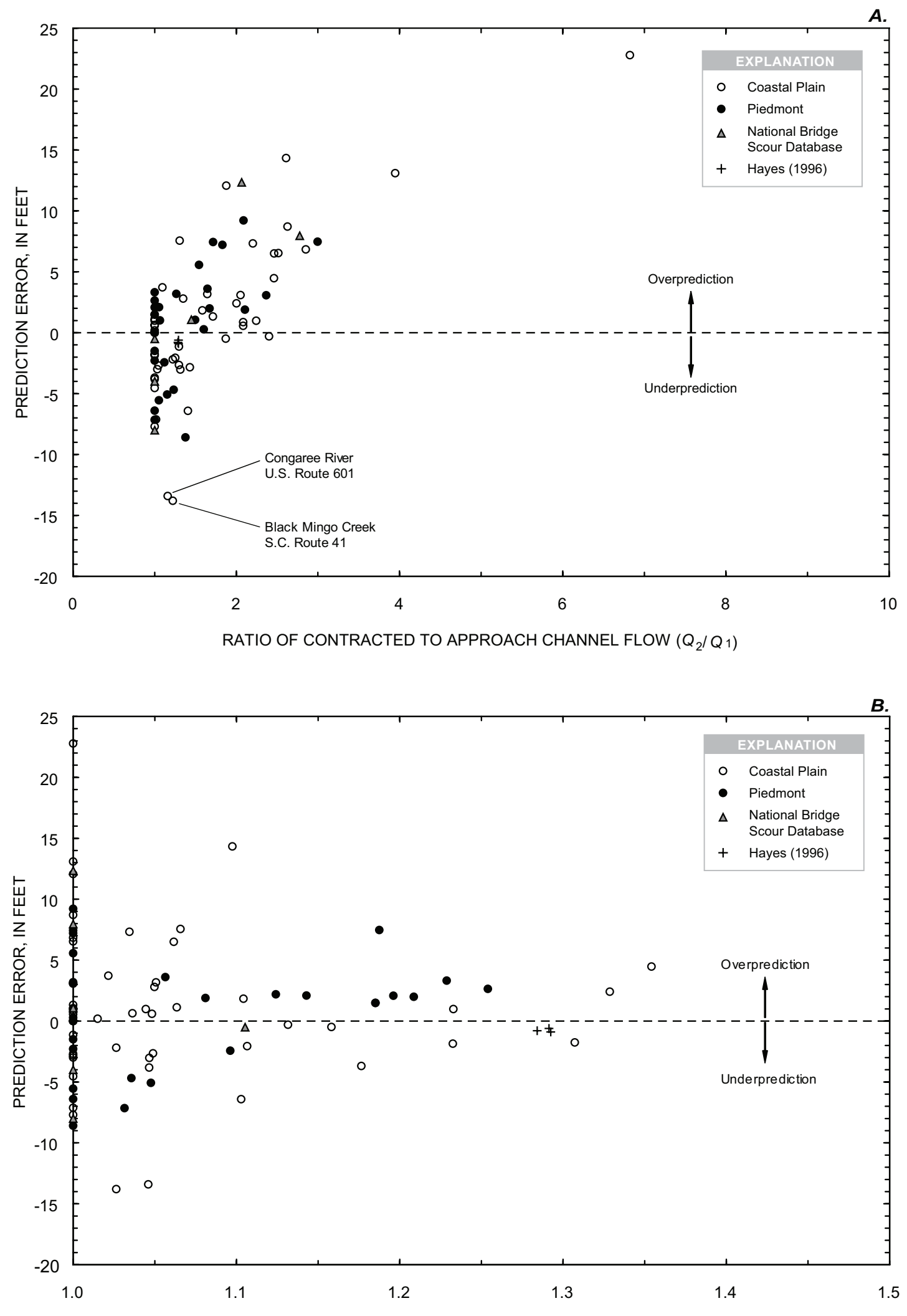

Figure 59. Relation of prediction error for livebed contraction-scour depth to $(A)$ the ratio of contracted to approach channel flow $\left(Q_{2} / Q_{1}\right)$ and $(B)$ the ratio of approach to contracted channel width $\left(W_{1} / W_{2}\right)$ at selected sites in South Carolina and selected data from the National Bridge Scour Database and Hayes (1996). [Prediction error was determined by subtracting the most likely estimate of measured scour from the predicted scour calculated with the modified Laursen equation (Richardson and Davis, 2001) and with the limitation that the flow and width ratios be rounded up to a value of 1 if they are RATIO OF APPROACH TO CONTRACTED CHANNEL WIDTH $\left(W_{1} / W_{2}\right)$ less than 1.] 

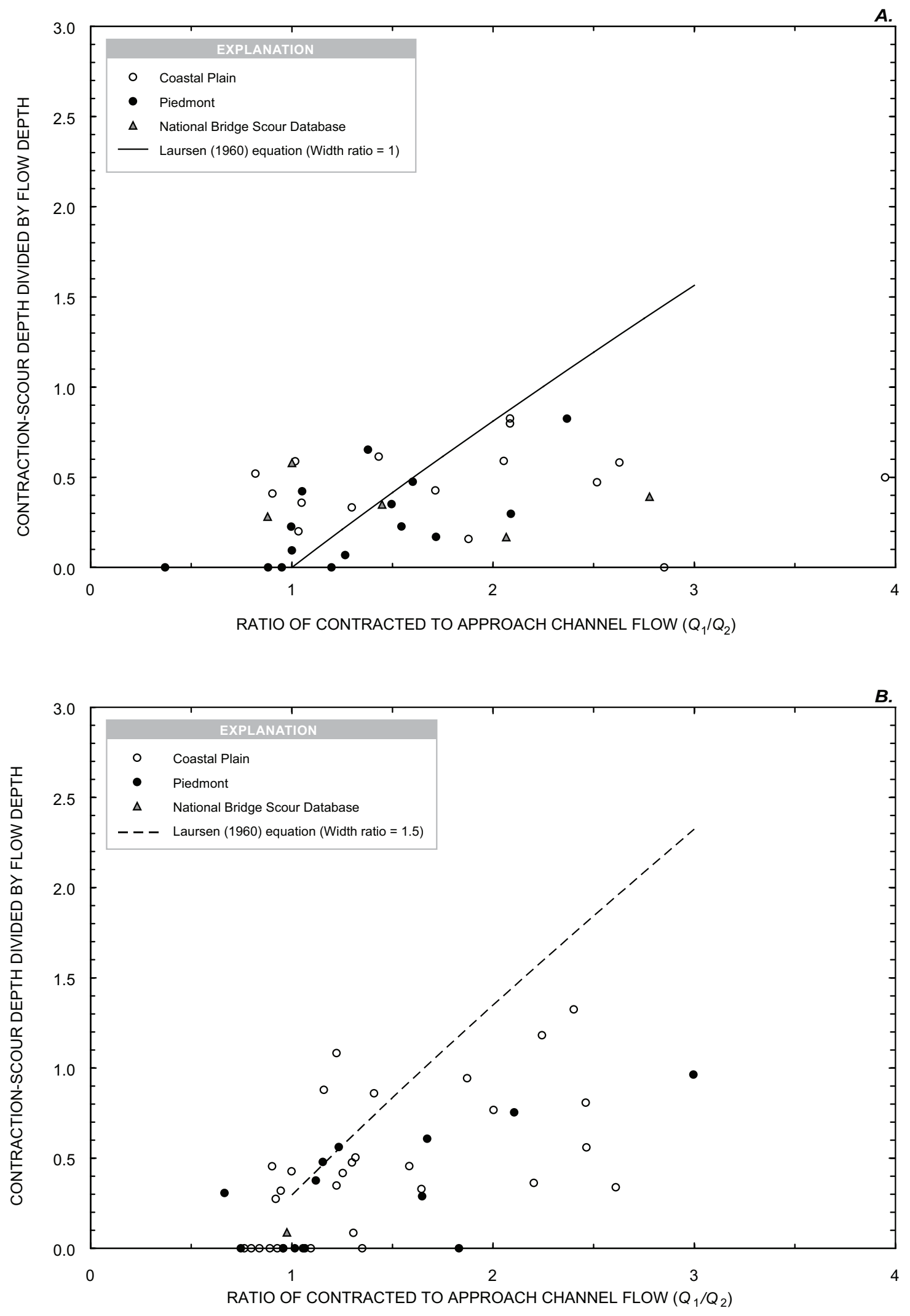

Figure 60. Relation of normalized live-bed contraction-scour depth to the contracted flow ratio $\left(Q_{2} / Q_{1}\right)$, at selected sites in South Carolina and selected data from the National Bridge Scour Database compared with theoretical envelope curves generated with the Laursen (1960) equation for ( $A$ ) field data having width ratios less than or equal to 1 and $(B)$ field data having width ratios less than 1.5 and greater than 1. 


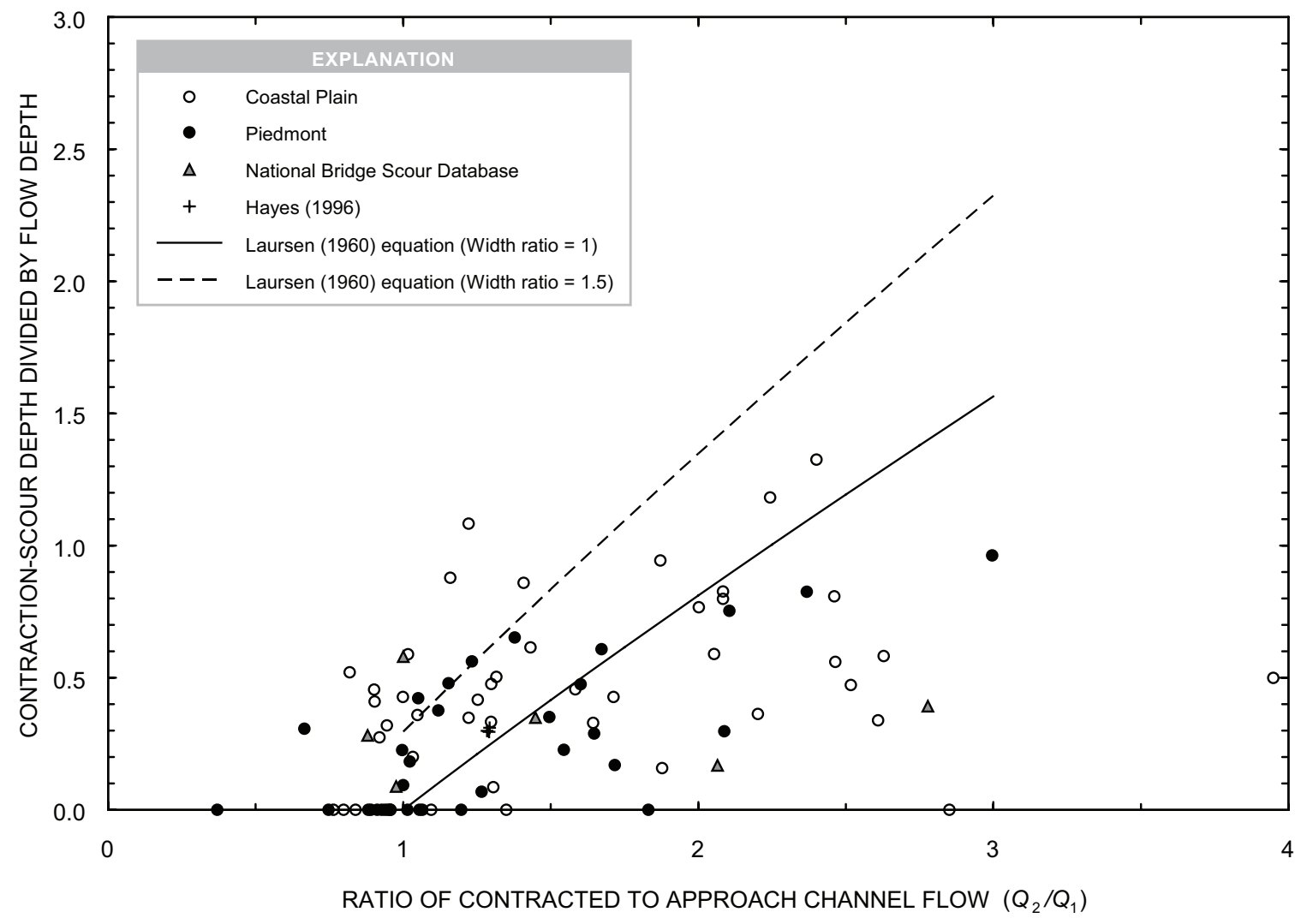

Figure 61. Relation of normalized live-bed contraction-scour depth to the contracted flow ratio $\left(Q_{2} / Q_{1}\right)$, at selected sites in South Carolina and selected data from the National Bridge Scour Database and Hayes (1996) compared with theoretical envelope curves generated with the Laursen (1960) equation.

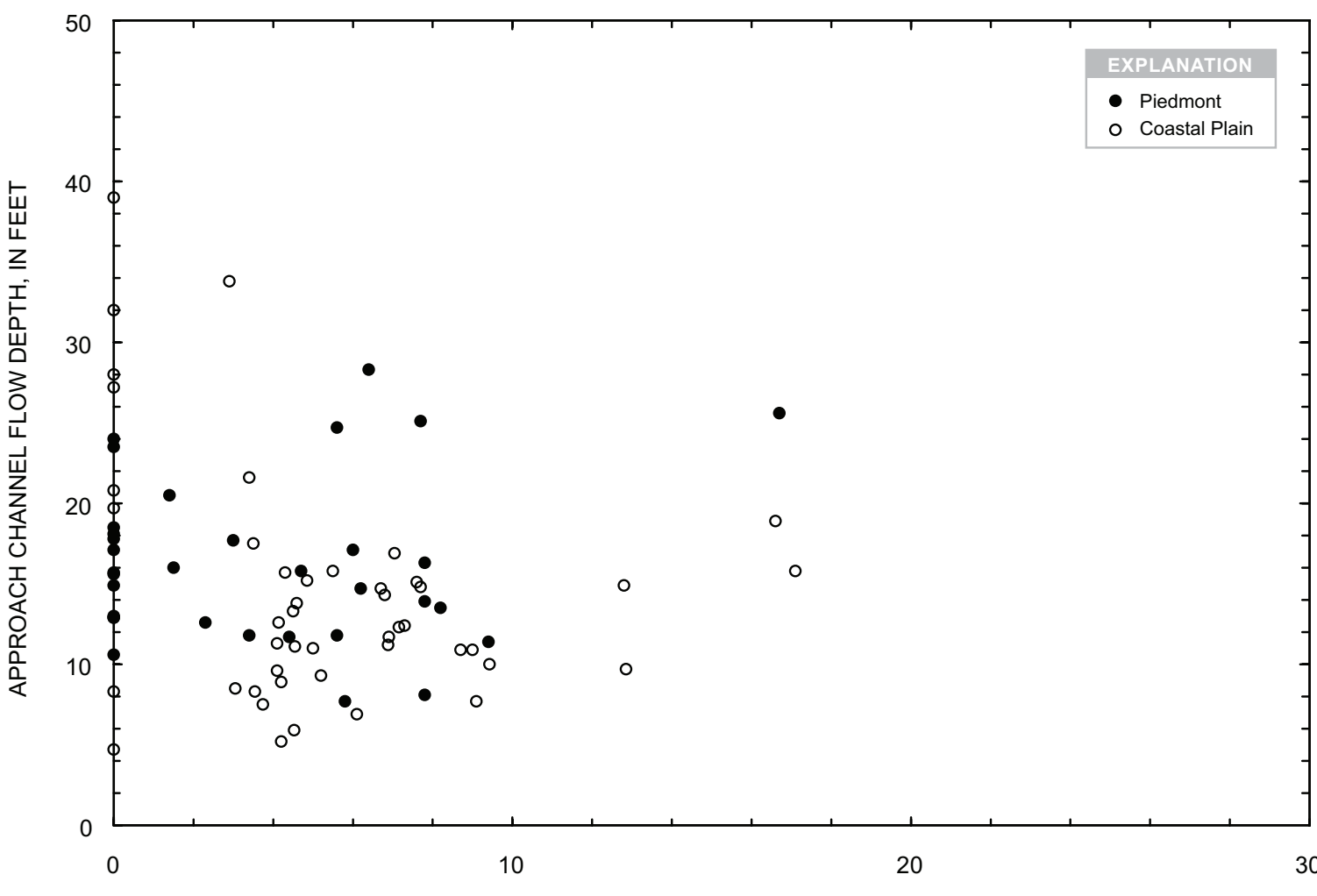

Figure 62. Relation of measured livebed contractionscour depth and the approach channel flow depth for selected sites in the Coastal Plain and Piedmont Physiographic Provinces of South Carolina. 


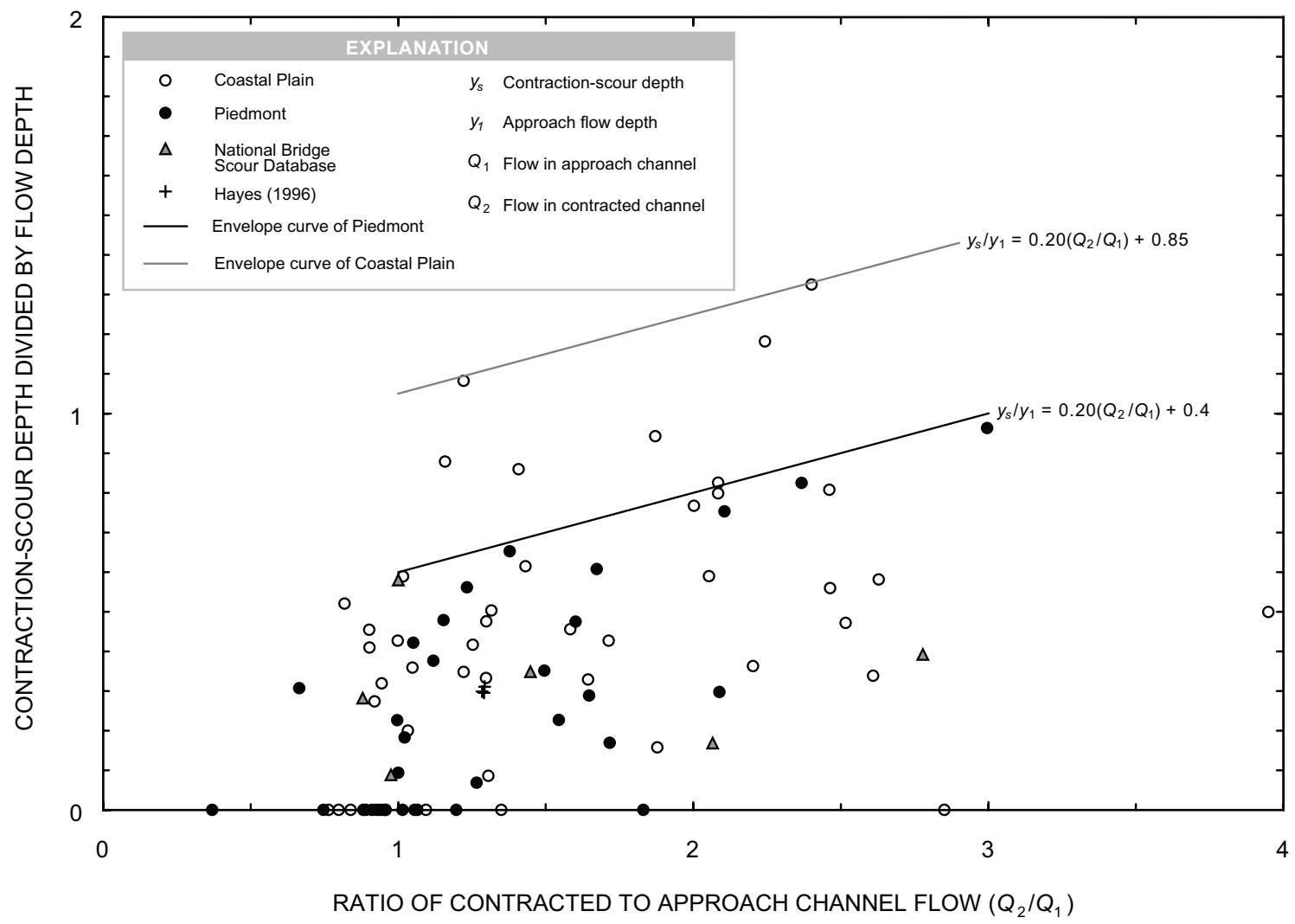

Figure 63. Relation of normalized live-bed contraction-scour depth to the contracted flow ratio $\left(Q_{2} / Q_{1}\right)$, at selected sites in South Carolina and selected data from the National Bridge Scour Database and Hayes (1996) with envelope curves for the Coastal Plain and Piedmont Physiographic Provinces of South Carolina.

the total flow at the approach and bridge sections would be equal to the flow passing through the bridge of interest rather than the flow across the entire floodplain.) Therefore, the channel flow ratio can be removed from the equation, making the live-bed scour a direct function of the bridge contraction and flow depth. Applying these assumptions to equation 9, leads to the following relation:

$$
\frac{y_{s}}{y_{1}}=\left[\frac{W_{1}}{W_{2}}\right]^{k_{1}}-1,
$$

where all variables are as previously defined. With the assumption of rectangular cross sections, the flow top widths at the approach and bridge cross sections can be used to determine the channel width ratio. Rearranging equation 10 , the channel width ratio can be replaced with the geometric-contraction ratio, which is a common variable in bridge hydraulics that defines the severity of flow contraction created by a bridge. The geometric-contraction ratio $(m)$ is defined as $m=1-b / B$, where $B$ is the approach flow top width in feet and $b$ is the bridge-opening top width in feet. Substituting $W_{2}$ for $b$ and $W_{1}$ for $B$, equation 10 can be rearranged to the following:

$$
\frac{y_{s}}{y_{1}}=\left[\frac{1}{1-m}\right]^{k_{1}}-1 \text {, }
$$

where all variables are as previously defined. (Note: The $k_{1}$ exponent was assumed to be the average value of 0.64.) Figure 64 shows the theoretical curve for equation 11, along with the dimensionless values determined for the South Carolina, the NBSD, and Hayes (1996) live-bed contraction-scour field data. Additionally, the selected clear-water contractionscour data (Benedict, 2003), as described previously, are included. The vertical axis represents scour depth normalized by the approach channel flow depth, and the horizontal axis represents the geometric-contraction ratio. (Note: The geometric-contraction ratios were primarily determined from one-dimensional flow models using the historic flows and, in several cases, were estimated from topographic maps.) The theoretical curve for equation 11 is essentially an envelope curve for the upper bound of the field data with only one data point exceeding the curve. The point that exceeds the curve is not excessive and is associated with a channel bend that may tend to increase scour depths. The relations in the field data and dimensionless envelope curve of equation 11 indicate that larger contraction scour depths should be associated with larger geometric-contraction ratios.

The simplifying assumptions used to develop equation 11 may bring into question the validity of its use; however, the conformity of the upper bound of the field data to the equation curve in figure 64 indicates that the equation is capturing the upper-bound trends of the field data. Equation 11 may be capturing the field trends because the geometric-contraction ratio is related to the channel flow ratio $\left(Q_{2} / Q_{1}\right)$ as defined 


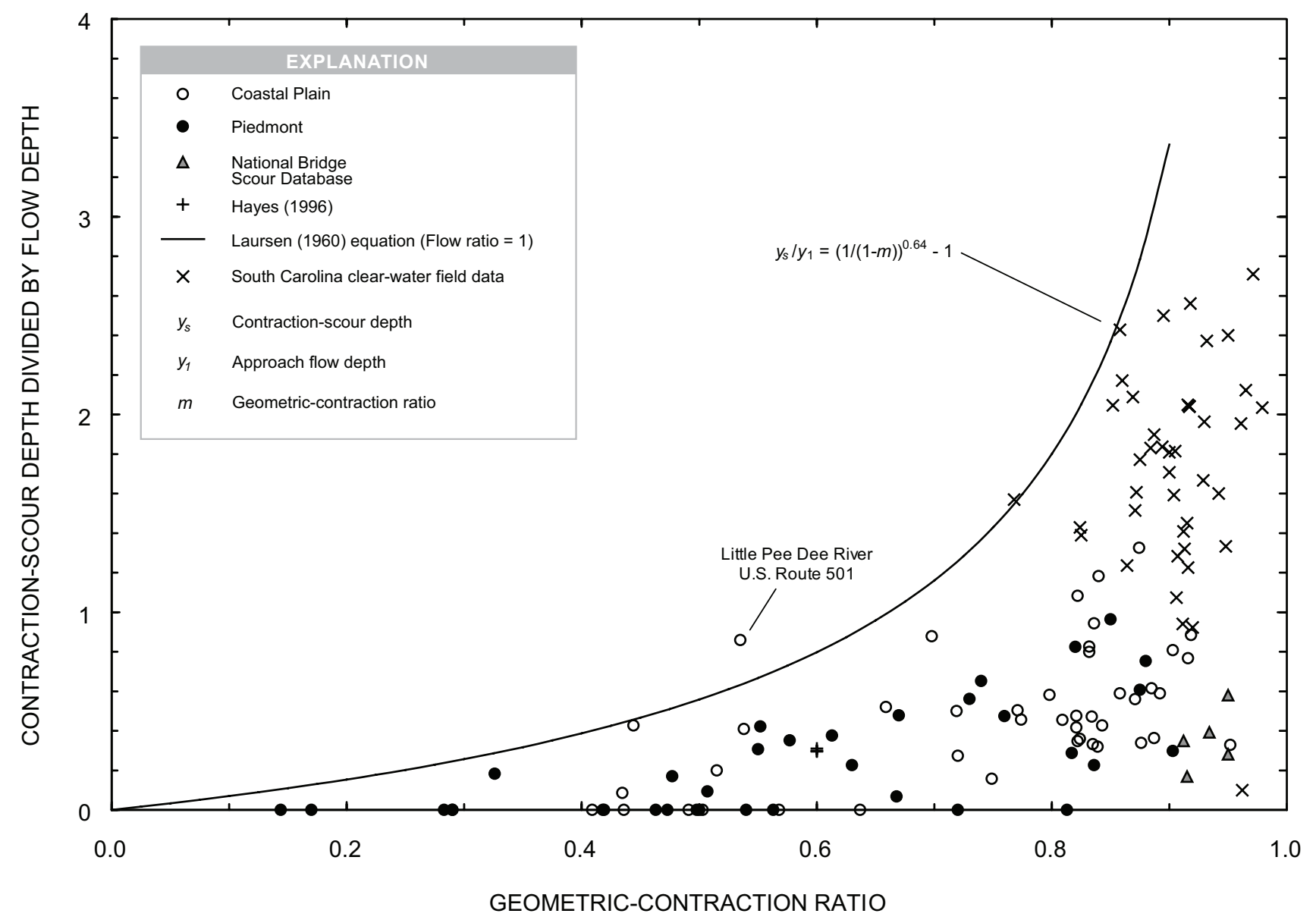

Figure 64. Relation of normalized live-bed contraction-scour depth to the geometric-contraction ratio at selected sites in South Carolina and selected data from the National Bridge Scour Database and Hayes (1996) compared with the theoretical envelope curve generated with the Laursen (1960) equation with the flow ratio set to 1.

in the modified Laursen (1960) equation (Richardson and Davis, 2001). Figure 65 shows the relation of the geometriccontraction ratio to the channel flow ratio for the South Carolina live-bed contraction-scour data. While there are a few outliers in figure 65 , the general trend shows a curve shaped similar to that of figure 64 . For geometric-contraction ratios less than approximately 0.6 , the rate of change for the curves in figures 64 and 65 is small. For geometric-contraction ratios greater than approximately 0.6 , the rate of change significantly increases for both curves. If the channel flow ratio is considered an important hydraulic variable that drives contraction scour, then the geometric-contraction ratio can be viewed as a geometric variable that functions as a surrogate for that hydraulic variable. This perhaps gives some explanation for why the curve of equation 11 does well in encompassing the upper bound of the field data.

The South Carolina clear-water contraction-scour data are encompassed well by the dimensionless envelope curve defined by equation 11 (fig. 64), suggesting that the equation may have application to clear-water contraction scour. However, this would need further investigation prior to recommending it for such application. It is of interest that the dimensionless scour depths for the South Carolina clear-water contractionscour data, in general, exceed the live-bed contraction-scour data. This is primarily caused by the significantly smaller flow depths associated with the clear-water contraction-scour data. The clear-water contraction-scour data occur on the floodplain where flow depths are smaller than in the channel where the live-bed contraction-scour data were collected. The relation of measured contraction-scour depth to the approach-flow depth for the South Carolina live-bed and clear-water contractionscour data is shown in figure 66. The range of scour depths is similar; however, the range of flow depths substantially differs between the live-bed and clear-water contraction-scour data. Therefore, for comparable contraction-scour depths, the clearwater contraction-scour data will have larger dimensionless scour depths than the live-bed contraction-scour data. If the clear-water contraction-scour data were normalized by flow depths comparable to those of the live-bed contraction-scour data, they would have dimensionless scour depths similar to 


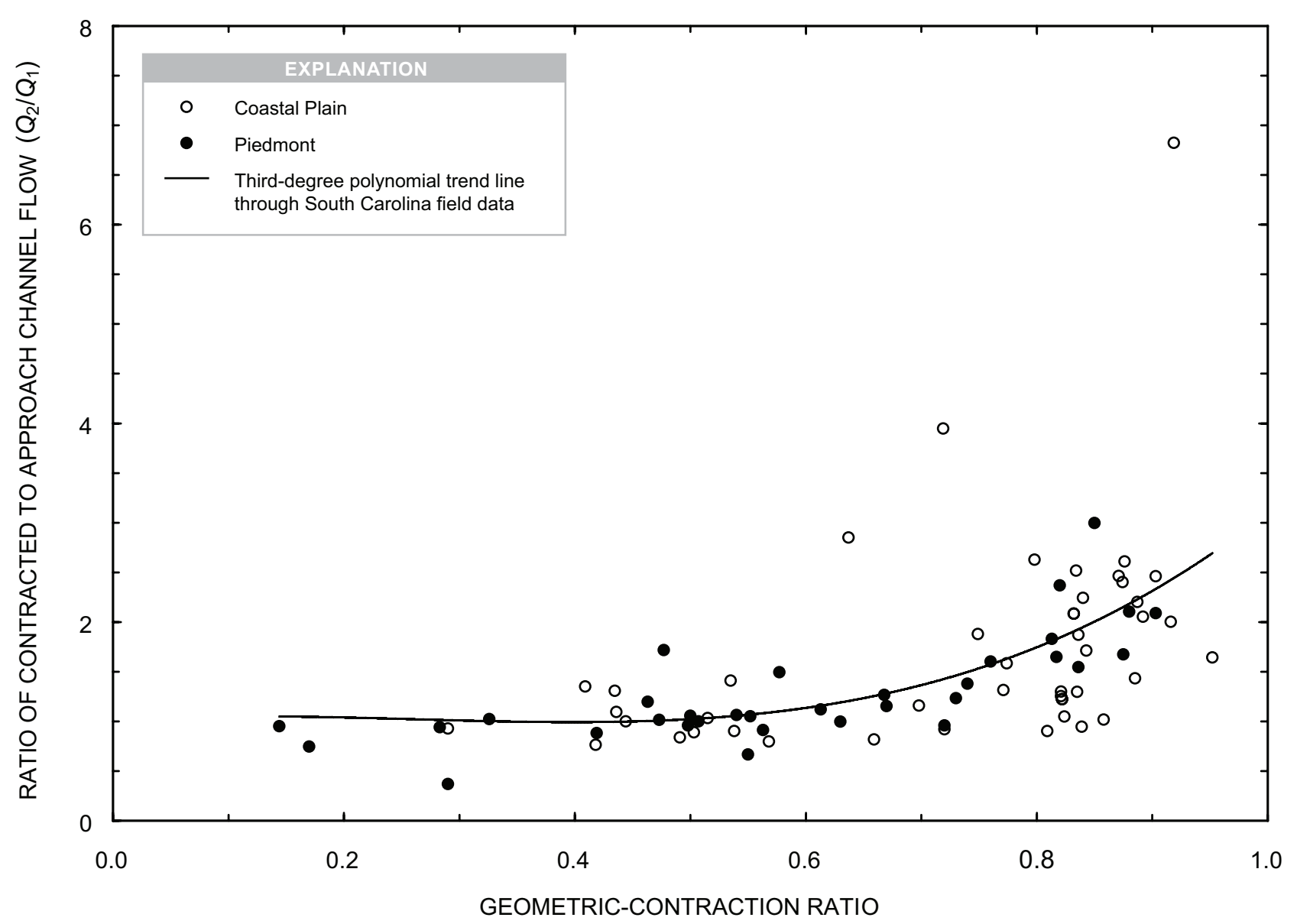

Figure 65. Relation of the channel flow ratio $\left(Q_{2} / Q_{1}\right)$ to the geometric-contraction ratio at selected sites in the Coastal Plain and Piedmont Physiographic Provinces of South Carolina.

those of the live-bed contraction-scour data. These observations highlight how equation 11 can be sensitive to the selection of the approach-flow depth and likely will be influenced by regional hydraulic trends.

The live-bed contraction-scour data are shown in figure 67 in a similar manner to that of figure 64 . As noted previously, the upper bound of the Coastal Plain data exceeds that of the Piedmont. Possible reasons for this trend are noted in the text describing figure 63. Envelope curves of the dimensionless field data for the Coastal Plain and Piedmont of South Carolina can be drawn (fig. 67). (Note: The one Coastal Plain data point that exceeds the envelope curve can be associated with a channel bend that may tend to increase scour depths.) Equations 12 and 13 represent the dimensionless envelope curves for the Coastal Plain and Piedmont of South Carolina, respectively.

Coastal Plain equation

$$
\frac{y_{u b s}}{y_{1}}=1.27 m^{2}+0.43 m
$$

Piedmont equation

$$
\frac{y_{u b s}}{y_{1}}=1.21 m^{2}+0.19 m,
$$

where

$$
y_{u b s}=\text { the upper bound of scour, in feet, }
$$
and all other variables are as previously defined.

The dimensionless envelope curves in figure 67 and their associated equations (eq. 11-13) can be used to help assess live-bed contraction-scour potential in the Coastal Plain and Piedmont of South Carolina. Equation 11 reflects the Laursen equation (1960) with the assumptions of rectangular channels and is a general equation that can be applied to the Coastal Plain and the Piedmont. Equations 12 and 13 reflect the trends for the upper bound of the field data for the Coastal Plain and Piedmont, respectively, and can be used to refine the assessment of scour potential in those regions. The upper bound of the field data for the Coastal Plain and Piedmont (fig. 67) have geometric-contraction ratios limited to approximately 0.87 and 0.85 , respectively; therefore, the application of equations 12 


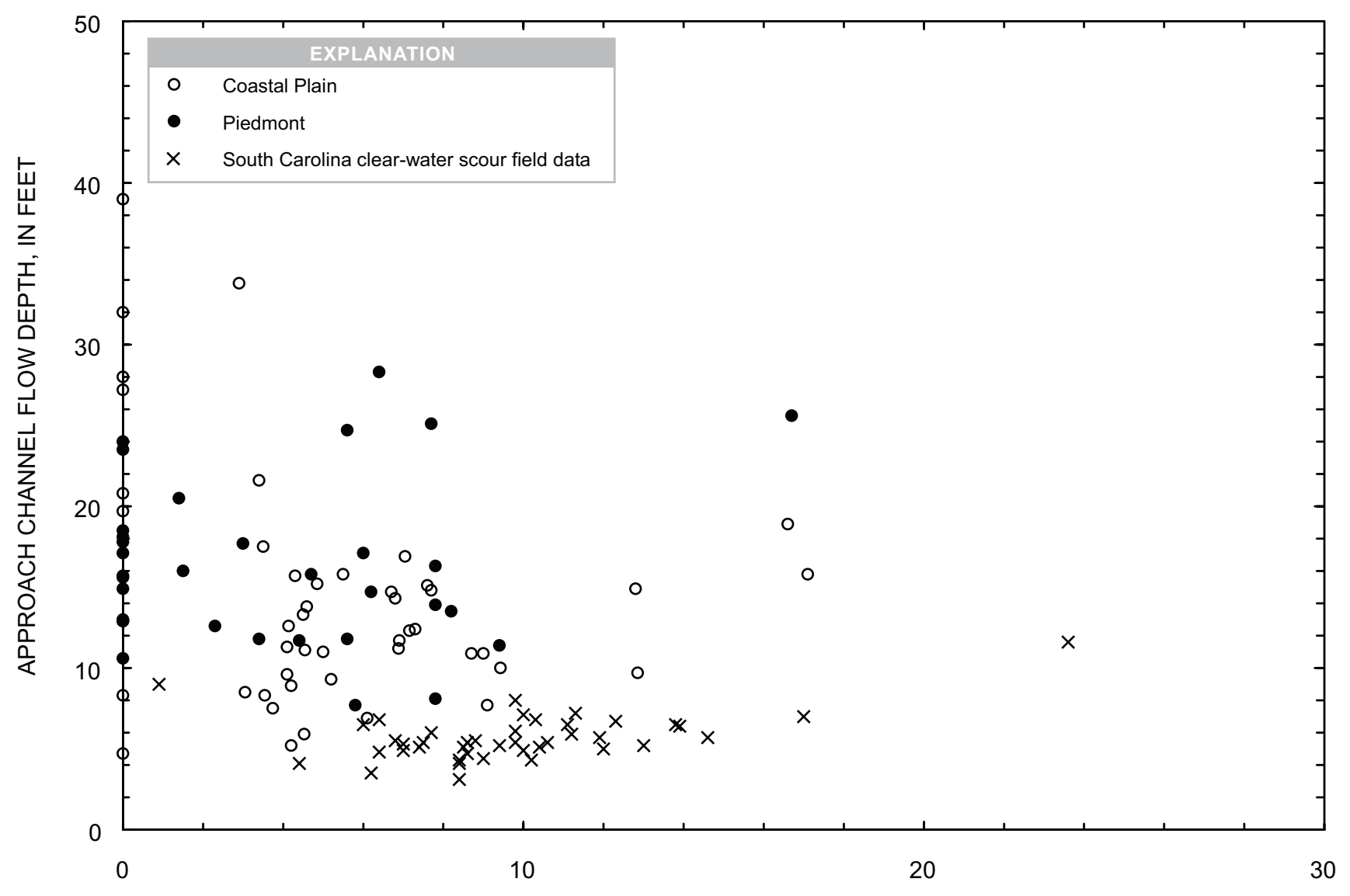

CONTRACTION-SCOUR DEPTH, IN FEET

Figure 66. Relation of measured contraction-scour depth and the approach channel flow depth for live-bed and clear-water contraction-scour data at selected sites in South Carolina.

and 13 beyond these values is questionable. In general, the application of these equations should be used with caution and should be limited to sites well within the range of the data used to develop the dimensionless envelope curves.

To understand how the dimensionless envelope curves in figure 67 will perform, they were applied to the South Carolina, the NBSD, and Hayes (1996) live-bed contraction-scour field data (fig. 68). The NBSD and Hayes (1996) data were assumed to be best represented by the Piedmont envelope curve. Underprediction is small and occurs only at the one site that exceeds the envelope curve. The overprediction for the South Carolina data can be large at times with an overprediction range from 0.1 to $19.2 \mathrm{ft}$ and a median value of $6.4 \mathrm{ft}$. Overprediction is generally smaller in the Piedmont than in the Coastal Plain. The relation of prediction error (predicted minus measured scour) to the channel flow and channel width ratios is shown in figure 69 , and the trends indicate that there is not a strong relation between the prediction error and the primary explanatory variables in the modified Laursen (1960) equation (Richardson and Davis, 2001). The relation of prediction error to the geometric-contraction ratio and the approach channel flow depth is shown in figure 70 and the trends indicate that the prediction error slightly increases with both variables. This gives some explanation for the excessive overprediction associated with one of the NBSD data where both the geometric-contraction ratio and flow depth associated with that data point are at or near the upper bound for the range of those variables. 

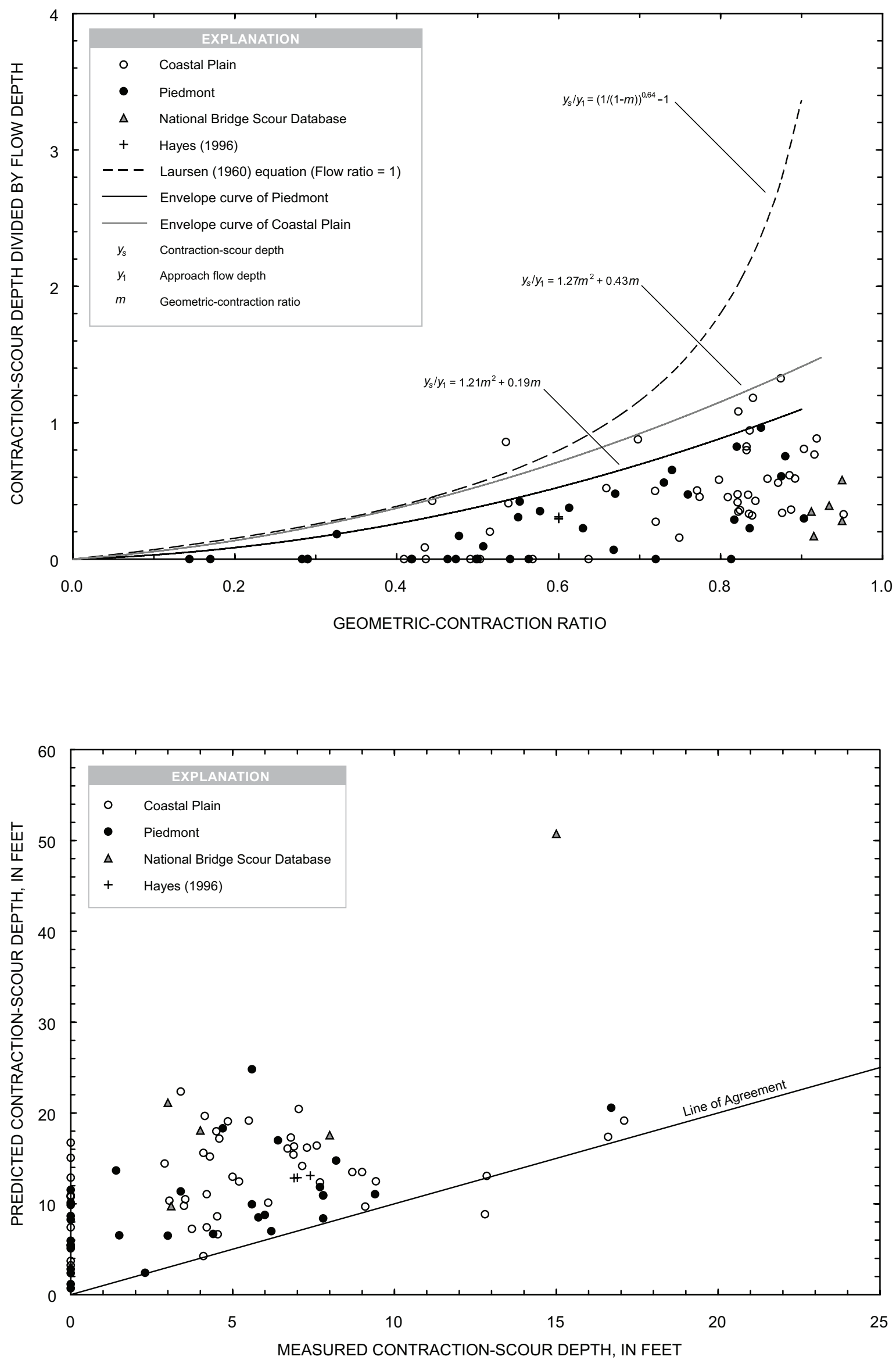

Figure 67. Relation of normalized livebed contractionscour depth to the geometriccontraction ratio at selected sites in South Carolina and selected data from the National Bridge Scour Database and Hayes (1996) with envelope curves for the Coastal Plain and Piedmont Physiographic Provinces of South Carolina.

Figure 68. Relation of measured to predicted livebed contractionscour depth at selected sites in South Carolina and selected data from the National Bridge Scour Database and Hayes (1996). (Predicted contraction scour was calculated with the dimensionless envelope curves in figure 67.) 


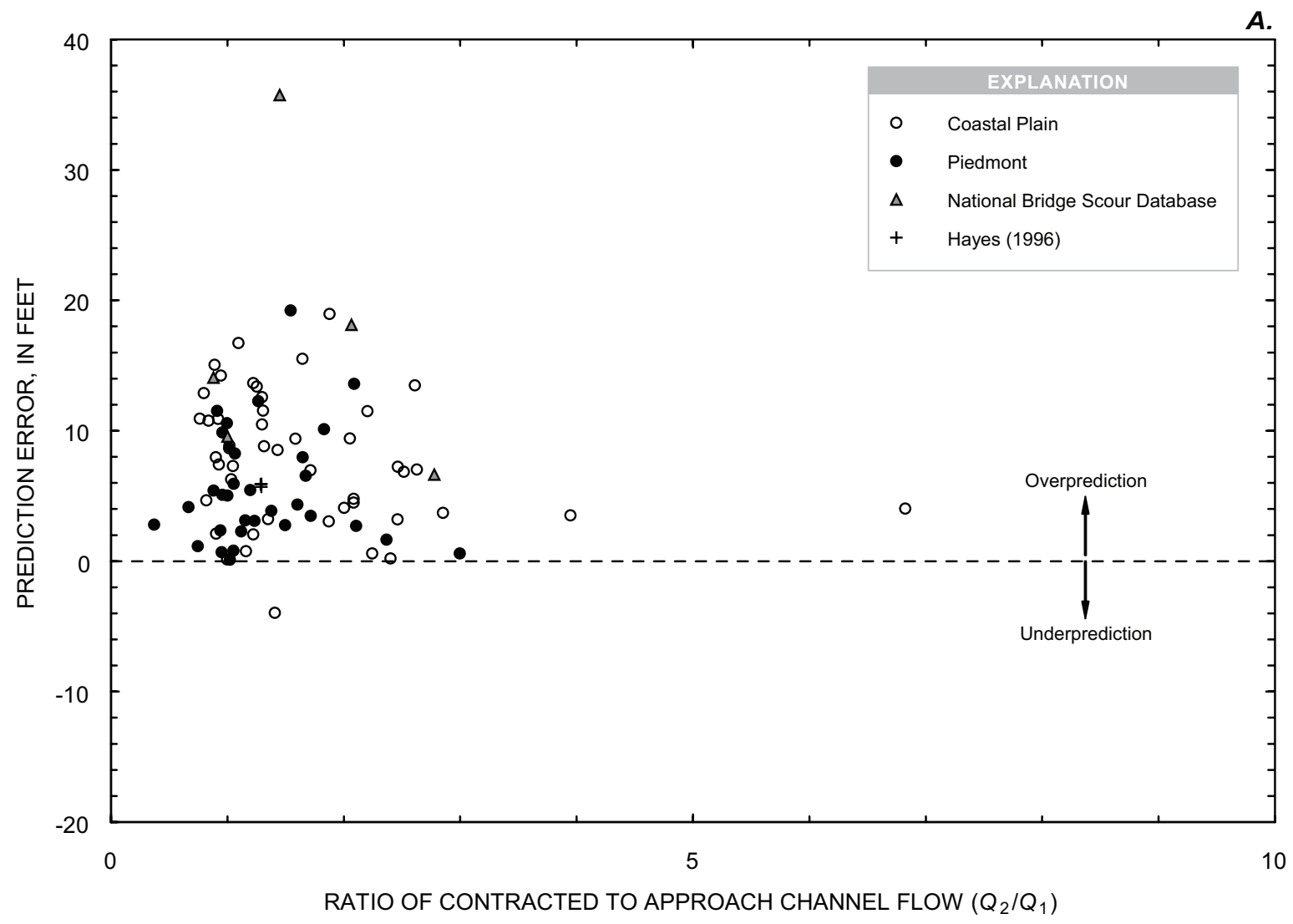

Figure 69. Relation of prediction

B. error for live-bed

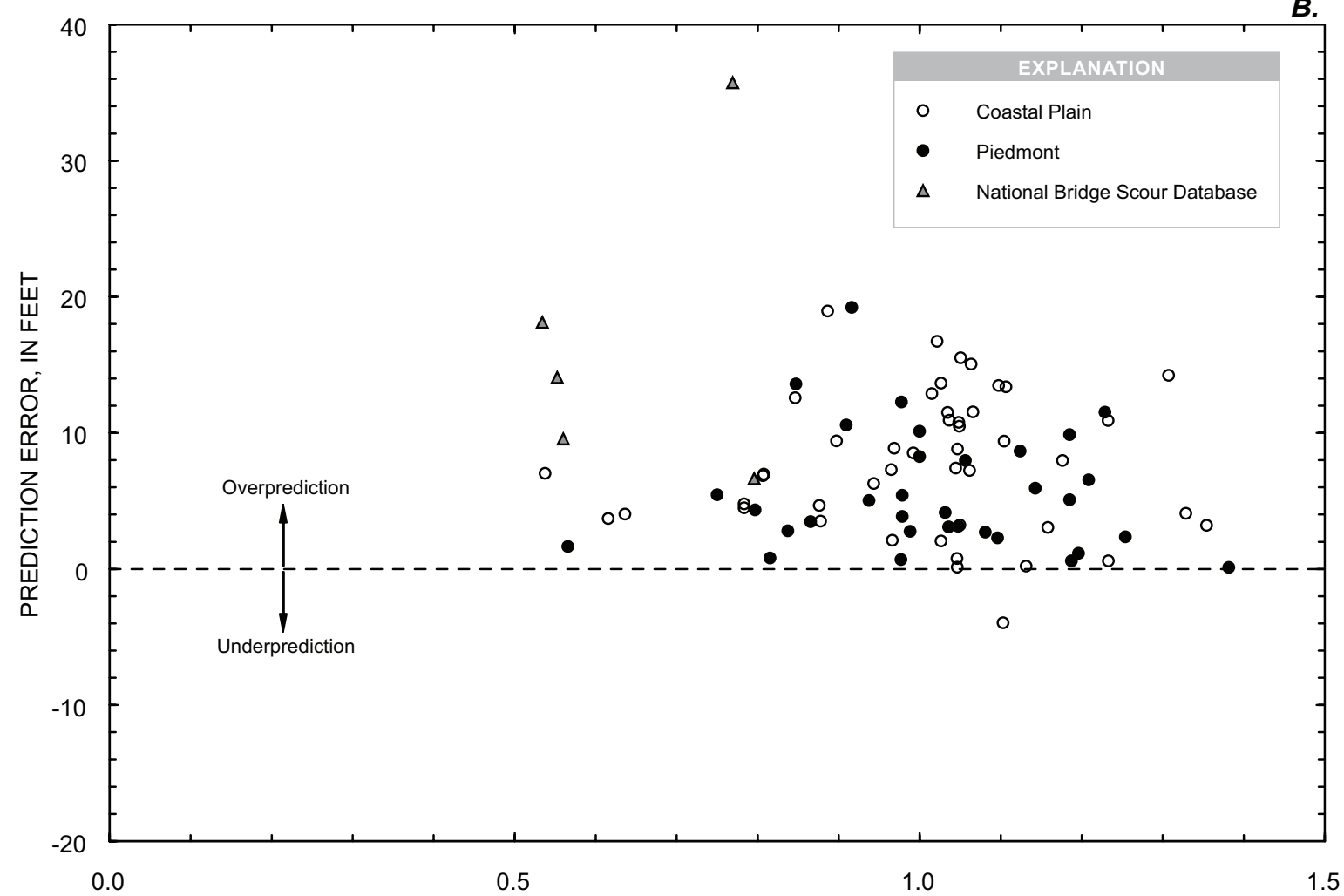
contraction-scour depth to $(A)$ the ratio of contracted to approach channel flow $\left(Q_{2} / Q_{1}\right)$ and $(B)$ the ratio of approach to contracted channel width $\left(W_{1} / W_{2}\right)$ at selected sites in South Carolina and selected data from the National Bridge Scour Database and Hayes (1996). (Prediction error was determined by subtracting the most likely estimate of measured scour from the predicted contraction scour calculated with the dimensionless envelope curves in RATIO OF APPROACH TO CONTRACTED CHANNEL WIDTH $\left(W_{1} / W_{2}\right)$ figure 67.) 
A.

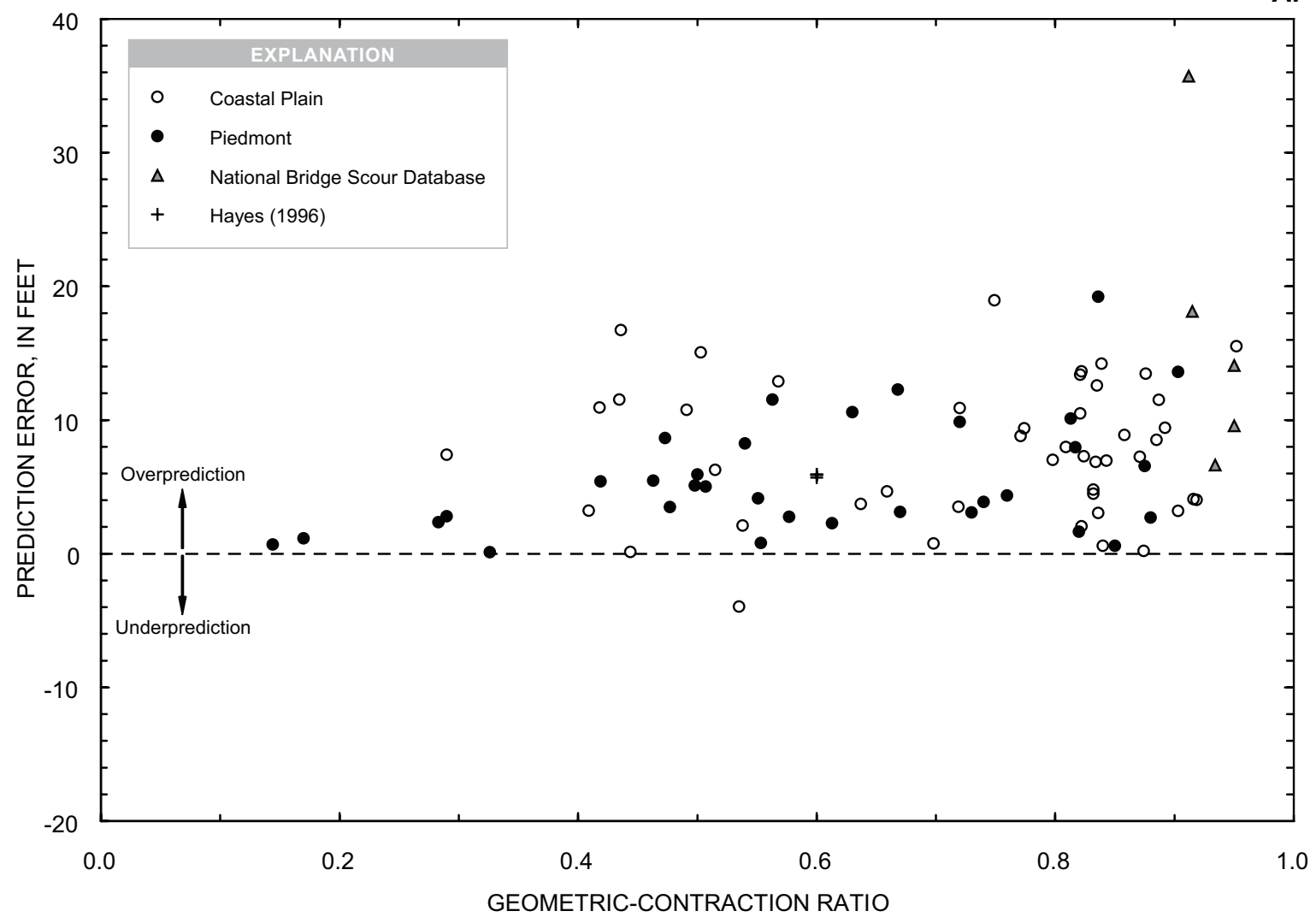

B.

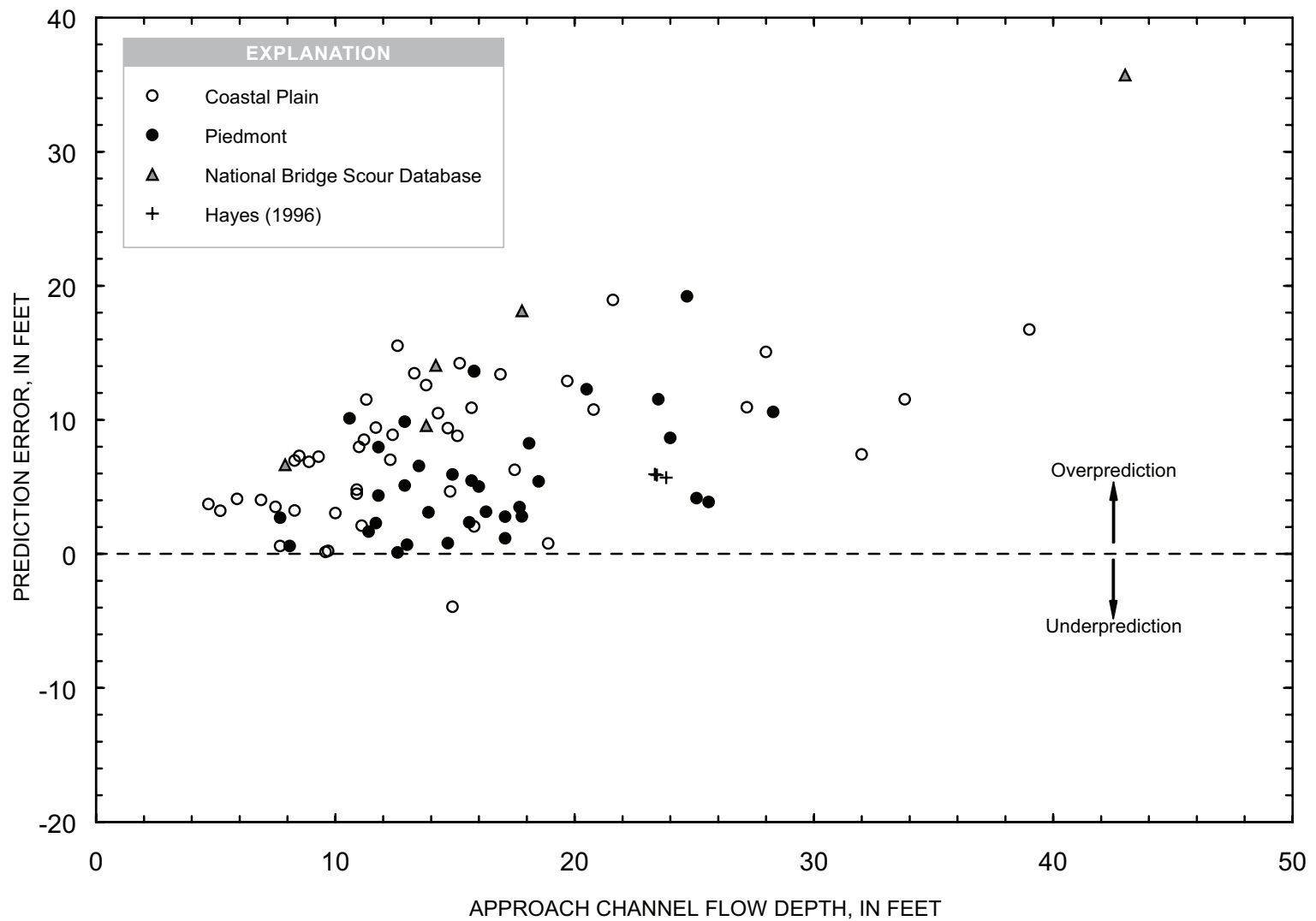

Figure 70. Relation of prediction error for live-bed contractionscour depth to $(A)$ the geometric-contraction ratio, and $(B)$ the approach flow depth, at selected sites in South Carolina and selected data from the National Bridge Scour Database and Hayes (1996). (Prediction error was determined by subtracting the most likely estimate of measured scour from the predicted contraction scour calculated with the dimensionless envelope curves in figure 67.$)$ 


\section{Field Envelope Curve for Live-Bed Contraction Scour}

The geometric-contraction ratio $(m)$, as previously defined, is an indicator of the severity of flow contraction created by a bridge. In general, as the geometric-contraction ratio increases, the potential for scour also increases (Das, 1973). This general trend was observed in the investigations of clear-water abutment and contraction scour in South Carolina (Benedict, 2003; Benedict and Caldwell, 2006). This general pattern also has been seen in the dimensionless envelope curves reviewed in the previous section of this report where the upper bound of dimensionless contraction scour increased with increasing geometric-contraction ratio. Based on these trends, it is reasonable to expect that the field measurements (dimensional values) of live-bed contraction-scour depth will show a similar pattern. The relation of the geometriccontraction ratio to measured live-bed contraction scour for the field data in South Carolina, the NBSD, and Hayes (1996) is shown in figure 71. (Note: The geometric-contraction ratios were primarily determined from one-dimensional flow models using the maximum historic flows and, in several cases, were estimated from topographic maps.) Figure $71 A$ shows the data and envelope curve for the most likely estimate of measured live-bed contraction scour for South Carolina. The two Coastal Plain measurements that exceed the envelope curve are associated with channel bends that will increase the potential for scour. The one Piedmont measurement that exceeds the curve is associated with debris. The scour measurement at Black Mingo Creek at S.C. Route 41 is the largest measurement of scour, and although possibly influenced by a channel bend, it was considered to be a good measurement for defining the upper bound of the envelope curve. Figure $71 B$ shows the data and envelope curve for the worst-case estimate of measured live-bed contraction scour for South Carolina. For comparison, the envelope curve for the most likely estimate of measured scour also is included in figure $71 B$. (Note: Figures $71 A$ and $71 B$ have the same number of scour measurements. The plotting positions of the scour measurement in figure $71 B$ may vary from those of figure $71 A$ if the worst-case [or more conservative] estimate of live-bed contraction scour differed from the most likely estimate of scour. As noted previously, the worst-case estimate of live-bed contraction scour accounts for possible uncertainty in the reference surface, GPR results, or both.) The three measurements that exceed the envelope curve are associated with sites where the worst-case estimate of measured scour was determined by assuming the scour reached the subsurface layer below the sandy channel sediments. The geometric-contraction ratio at these three sites is small, and significant live-bed contraction scour likely has not occurred at these sites. The envelope curve of the worst-case estimate of measured live-bed contraction scour (fig. $71 B$ ) is similar to the most likely scour envelope curve (fig. 71A) with only the addition of a value of $5.5 \mathrm{ft}$. Data from the Coastal Plain and Piedmont fall near both of the envelope curves in figure 71, indicating that separate envelope curves for these regions is not appropriate. Some regional differences may exist, but error associated with the field data likely obscures these differences.

While uncertainty is associated with both envelope curves, the upper bound of the data for the most likely measurement of live-bed contraction scour conforms well to the theoretical dimensionless envelope curves for the geometriccontraction ratio (fig. 64), suggesting that the envelope curve of these data is the most reasonable. This conclusion is supported by the limited field data from the NBSD and Hayes (1996) that fall within the envelope curve of the most likely measurement of live-bed contraction scour. Additionally, figure 72 shows the same relation as figure $71 A$ with the South Carolina clear-water contraction-scour data included. Interestingly, the clear-water contraction-scour data have a similar pattern to the most likely measurements of live-bed contraction scour. While the clear-water contraction-scour data are different in nature from live-bed scour data, the similarities in scour processes make the comparison useful to validate the trends of the live-bed contraction-scour data. (See report section "Other Sources of Field Data" for justification for using clear-water contraction-scour data.) The comparison suggests that the most likely live-bed contraction-scour measurements are reasonable and indicates that extending the envelope curve beyond the limits of the live-bed contraction-scour data may be appropriate. Based on these observations, it seems that the envelope curve for the most likely measurement of live-bed contraction scour appears to be a reasonable envelope curve for live-bed contraction scour in South Carolina.

Figure 73 shows the field envelope curve for the most likely measurement of live-bed contraction scour along with the field data, identifying the 64 contraction-scour measurements with known maximum historic flows. The contractionscour data have been grouped into four categories: (1) data associated with maximum historic flows from 0.7 to 1.3 times the 100-year flow, (2) data associated with maximum historic flows less than 0.7 times the 100-year flow, (3) data associated with maximum historic flows greater than 1.3 times the 100-year flow, and (4) data with unknown maximum historic flows. There are no streamflow gages on Black Mingo Creek for estimating the maximum historic flow at S.C. Route 41; however, the bridge was in place at the time of the 1945 flood and likely experienced a flow near the 100-year flow magnitude. (Table 1 lists six sites that experienced the 1945 flood with most sites having flow magnitudes near the 100-year flow.) If the Black Mingo Creek contraction-scour measurement (fig. 73) is grouped with the data associated with flow magnitudes between 0.7 to 1.3 times the 100 -year flow, the trends in figure 73 indicate that the data associated with maximum historic flows near the 100 -year flow magnitude ( 0.7 to 1.3 times the 100 -year flow) are the data that fit well within the envelope curve and define the upper bound of the data. This trend for the data associated with flow magnitudes between 0.7 and 1.3 times the 100-year flow indicates that the South Carolina live-bed contraction-scour envelope curve reflects an upper bound of scour for flows near the 100-year 
A.

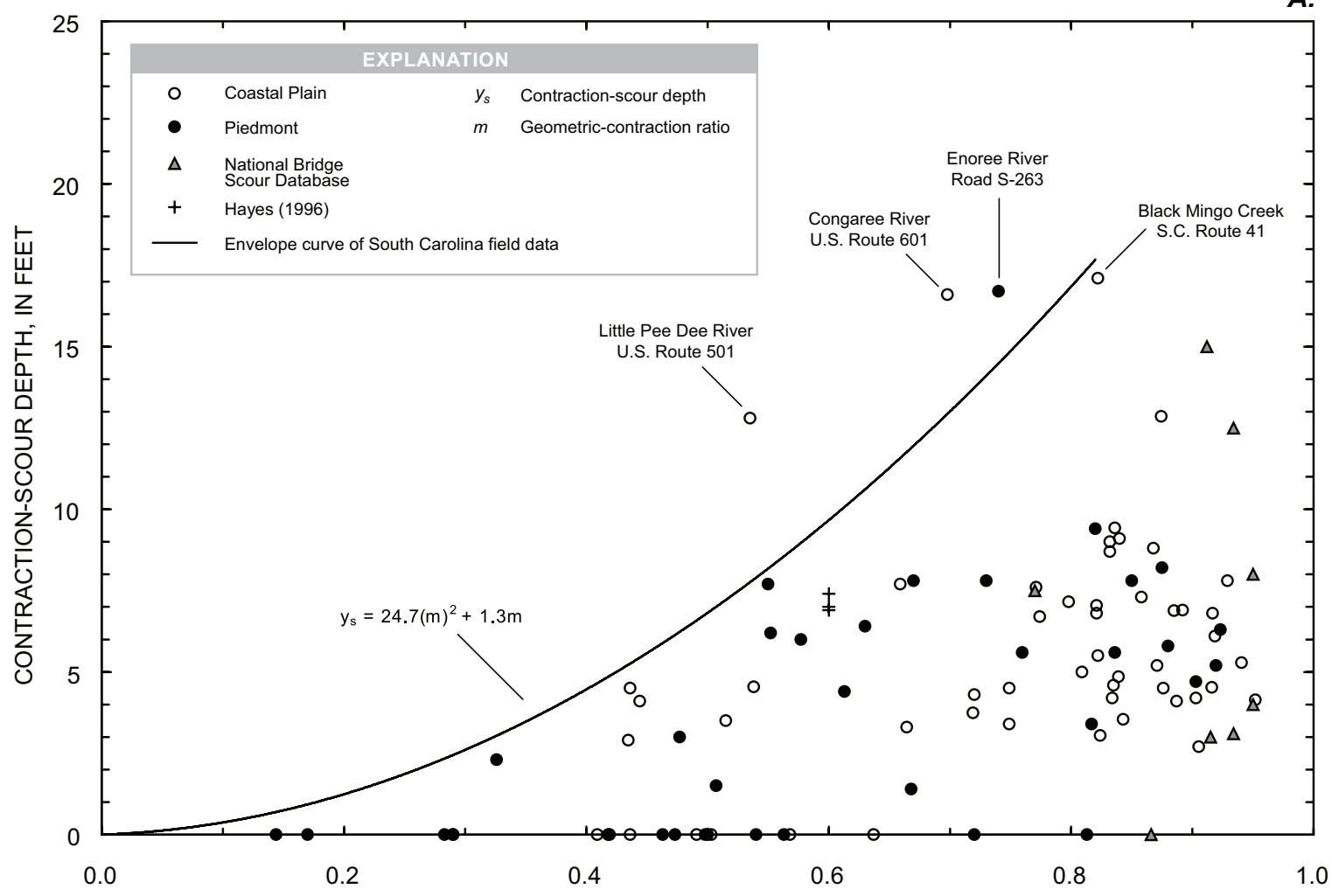

GEOMETRIC-CONTRACTION RATIO

B.

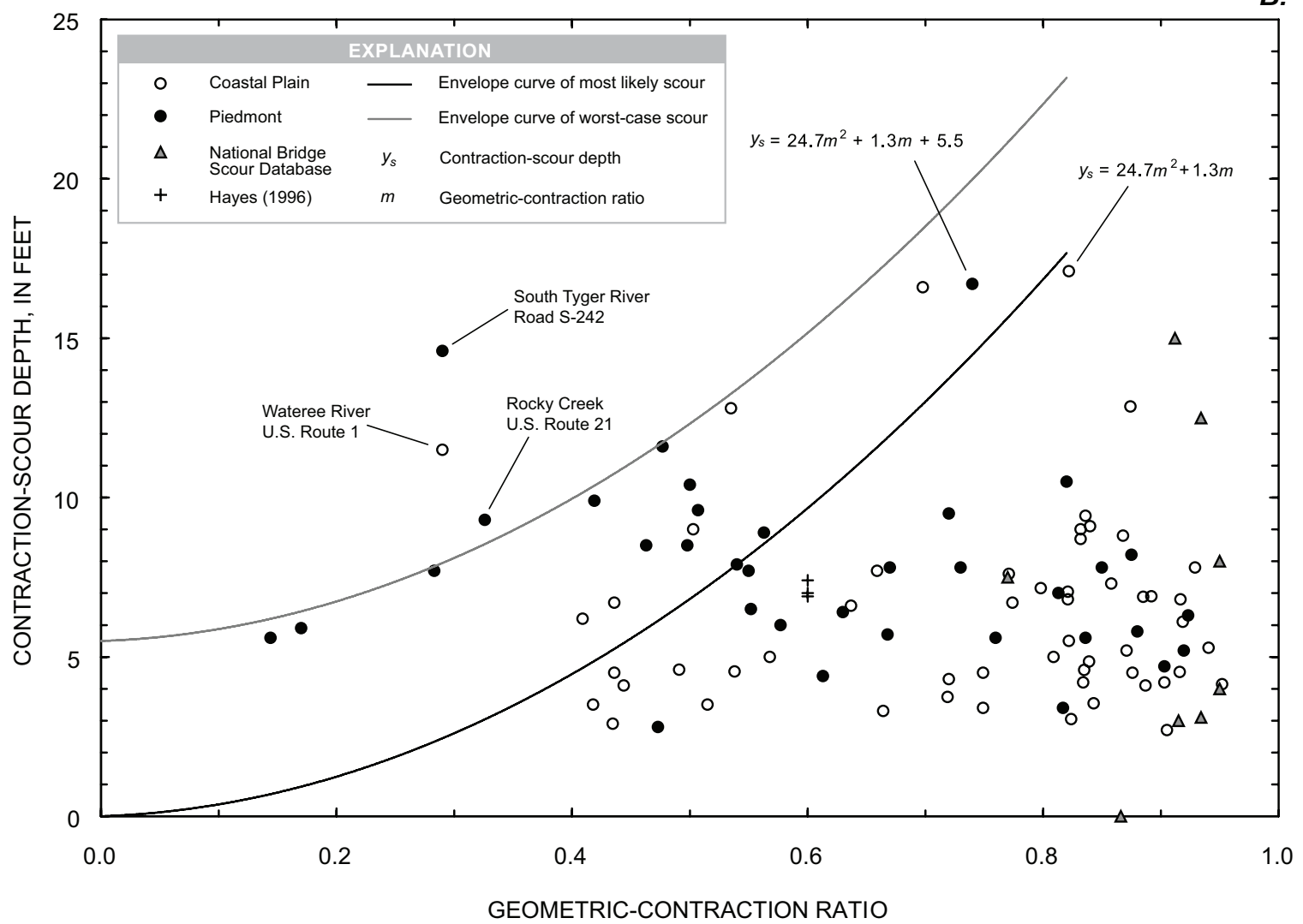

Figure 71. Relation of the geometric-contraction ratio and measured live-bed contraction-scour depth with envelope curves for $(A)$ the most likely estimate of measured scour depth and $(B)$ the worstcase estimate of measured scour depth at selected sites in South Carolina and selected data from the National Bridge Scour Database and Hayes (1996). 


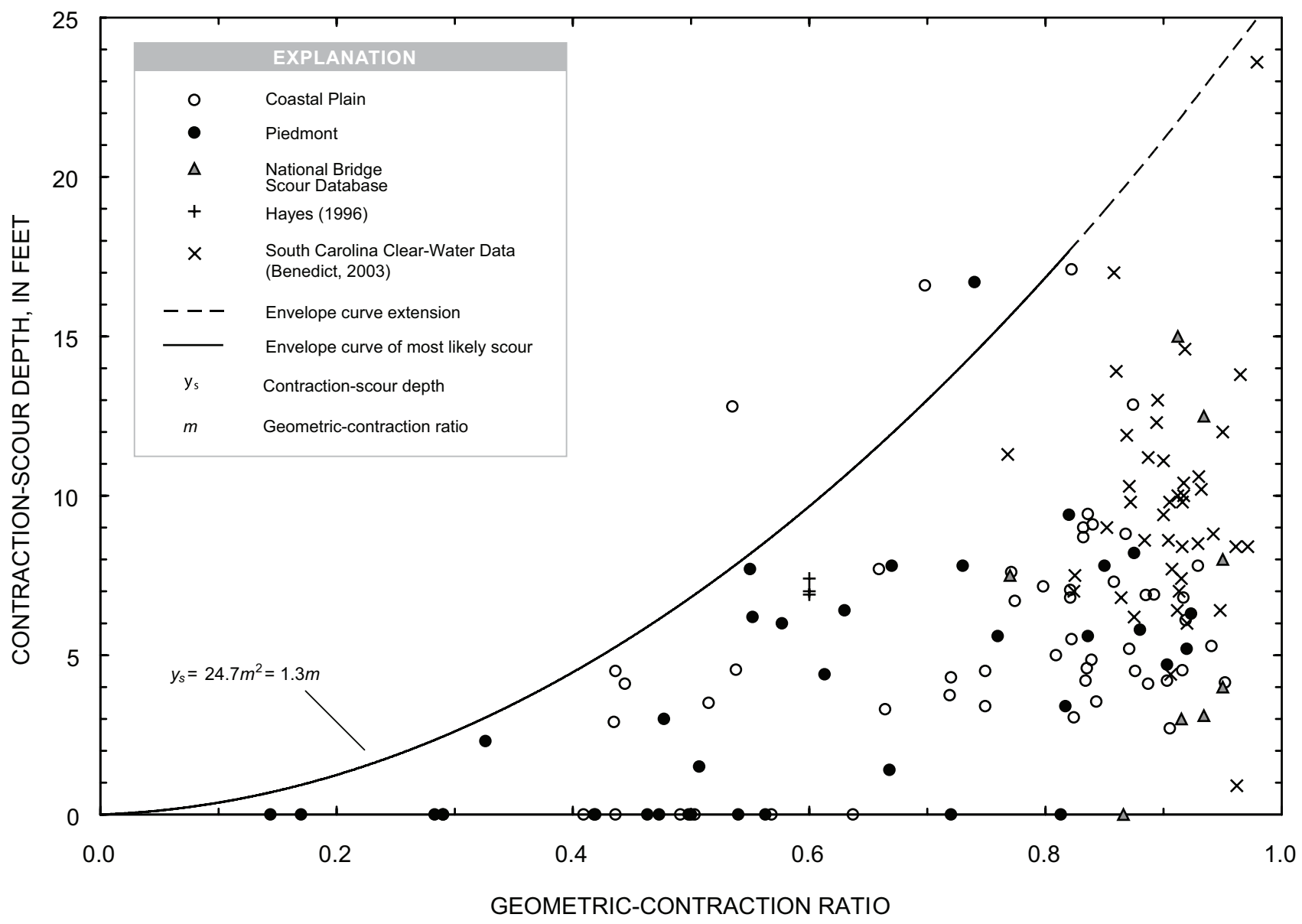

Figure 72. Comparison of the live-bed contraction-scour envelope for the South Carolina data to selected clear-water contraction-scour data collected in South Carolina.

flow magnitude and can be used to assess scour for such flow conditions. The equation for the field envelope curve of livebed contraction scour is as follows:

$$
y_{s}=24.7 m^{2}+1.3 m
$$

where all variables are as previously defined. The field envelope curve and its associated equation (eq. 14) can be used to help assess live-bed contraction-scour potential in the Coastal Plain and Piedmont of South Carolina. The upper bound of the field data for the Coastal Plain and Piedmont (fig. 71A) have geometric-contraction ratios limited to approximately 0.82 , indicating that the application of equation 14 beyond this value is questionable. However, the clear-water contraction-scour data (fig. 72) suggest that it may be appropriate to extend the envelope curve of the live-bed field data beyond a geometriccontraction ratio of 0.82 . The trend in figure 72 is not conclusive, and the envelope-curve extension should be used with caution. In general, the application of equation 14 should be used with caution and limited to sites well within the range of the data used to develop the envelope curves.

To understand how the envelope curve in figure $71 \mathrm{~A}$ will perform, it was applied to the South Carolina (most likely measurements), the NBSD, and Hayes (1996) livebed contraction-scour field data (fig. 74). Underprediction is small and occurs only at those sites that exceed the envelope curve as identified in figure 71A. (As noted previously, these sites are associated with field conditions that tend to create deeper scour depths.) The overprediction can be large at times (as large as $19.7 \mathrm{ft}$ ), with similar ranges of error in both the Coastal Plain and Piedmont. The range of overprediction for the NBSD and Hayes (1996) is within the range of the overprediction for the South Carolina data. The relation of prediction error to the geometric-contraction ratio and the approach channel flow depth is shown in figure 75, and the trends indicate that the prediction error increases with the geometric-contraction ratio but decreases with the approachflow depth. 


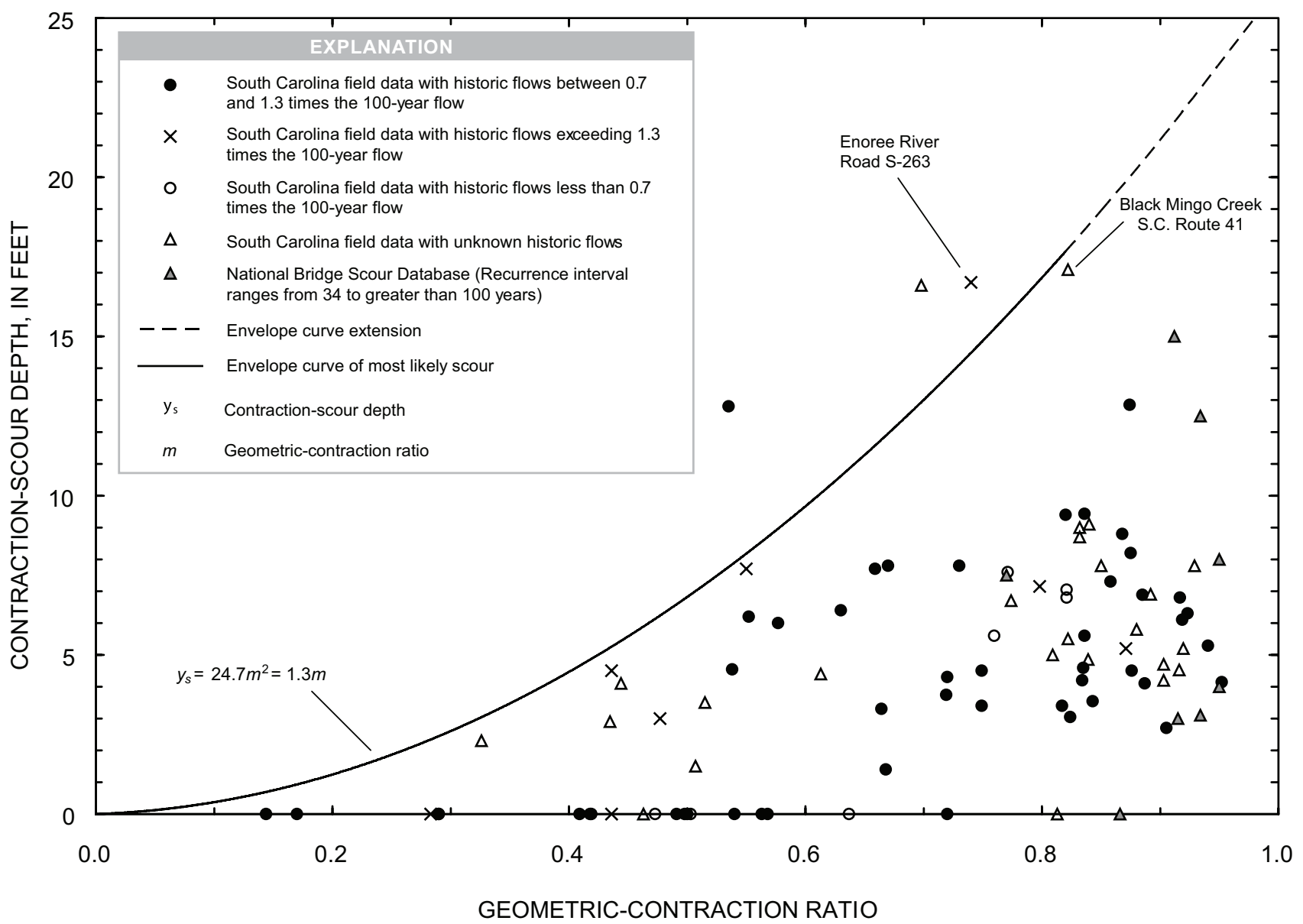

Figure 73. Selected data associated with maximum historic flows compared with the South Carolina field envelope curve.

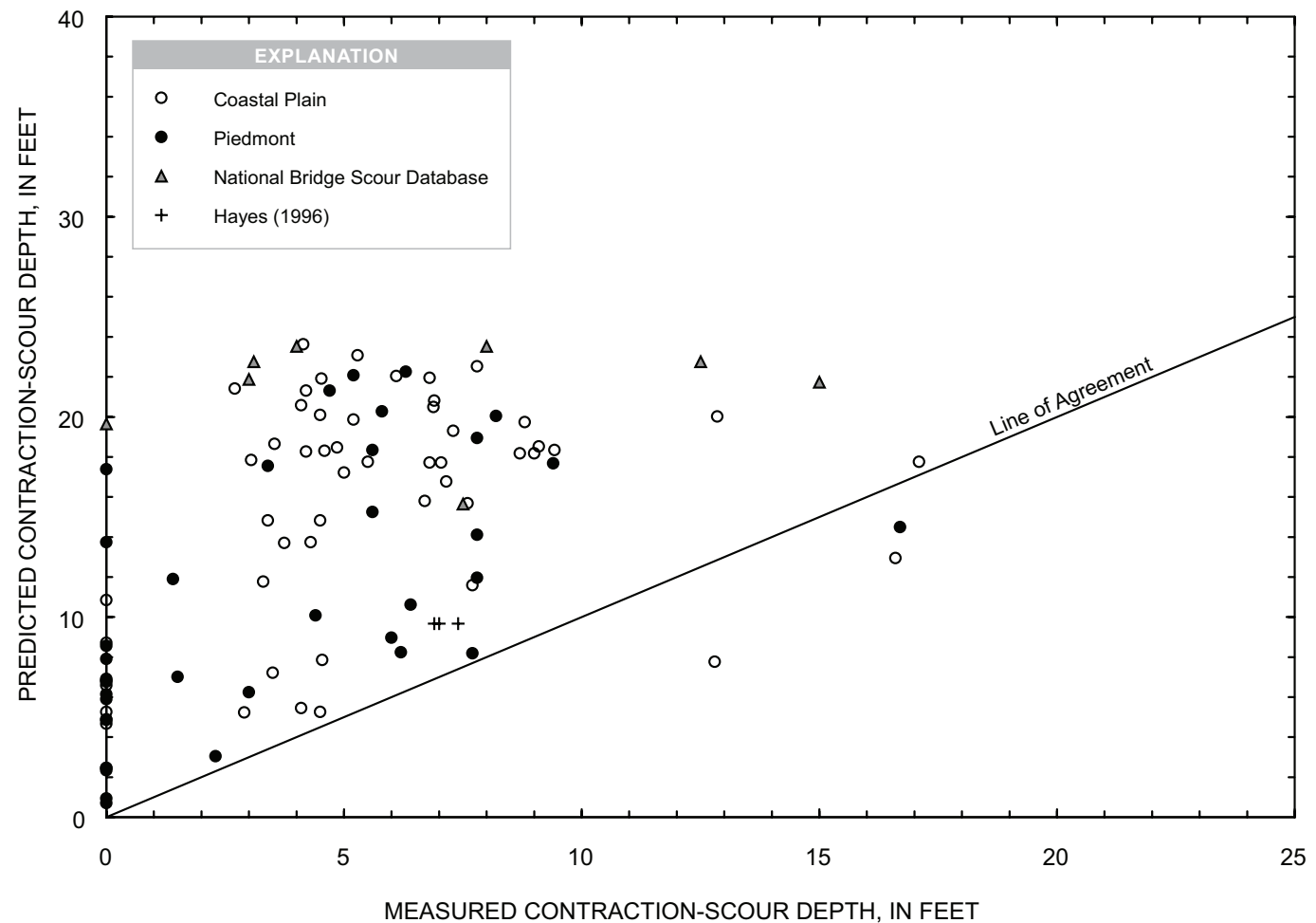

Figure 74. Relation of measured to predicted livebed contraction-scour depths at selected sites in South Carolina and selected data from the National Bridge Scour Database and Hayes (1996). (Predicted contraction scour was calculated with the South Carolina live-bed contractionscour field envelope equation.) 

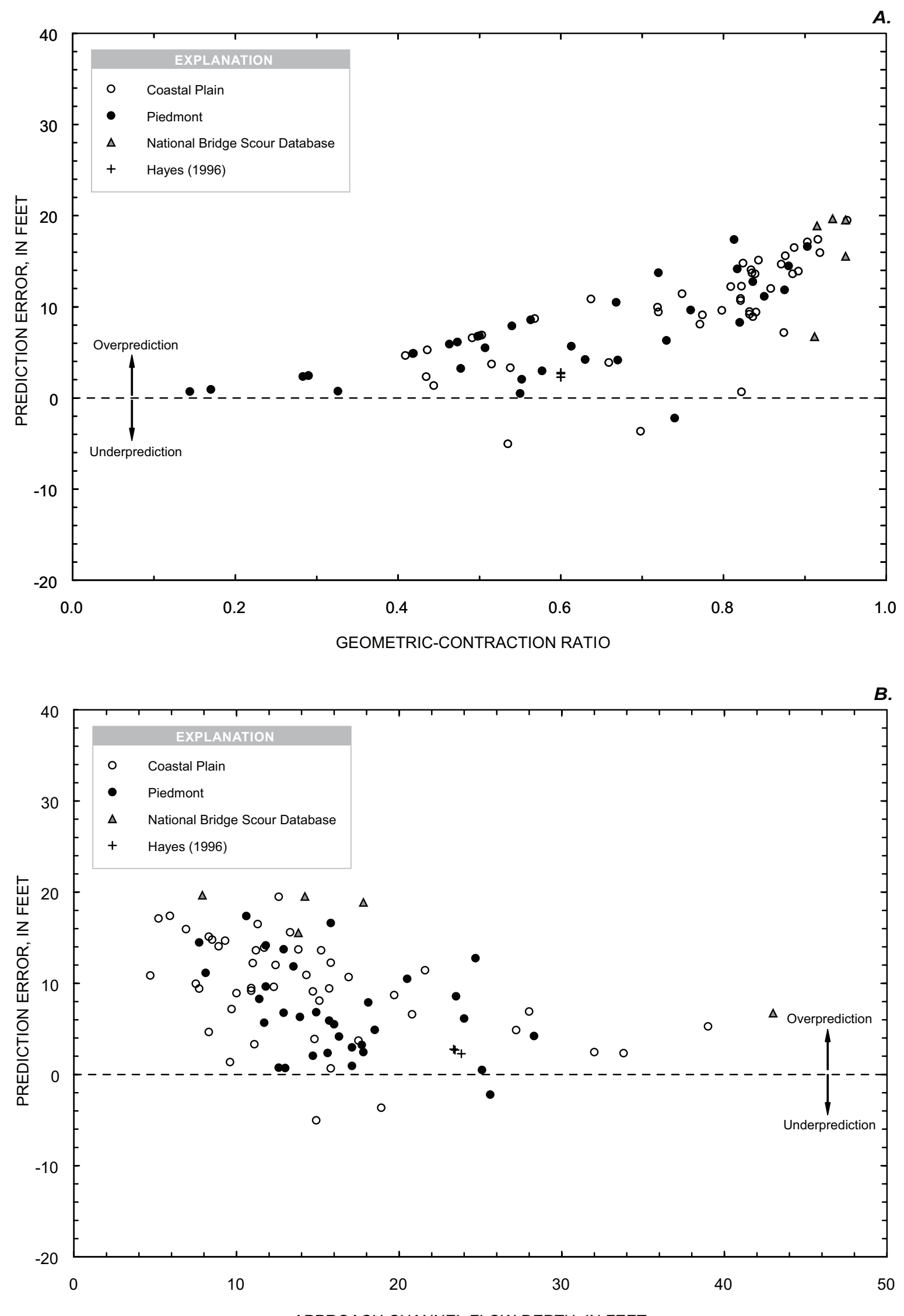

Figure 75. Relation

of prediction error for live-bed contraction-scour depth to $(A)$ the geometriccontraction ratio, and $(B)$ the approach-flow depth at selected sites in South Carolina and selected data from the National Bridge Scour Database and Hayes (1996). (Prediction error was determined by subtracting the most likely estimate of measured scour from the predicted scour calculated with the South Carolina live-bed contraction-scour field envelope equation.) 


\section{Comparison of Methods for Assessing Live-Bed Contraction Scour}

The dimensionless envelope curves in figure 67 (eqs. 12 and 13) and the field envelope curve in figure $71 A$ (eq. 14) represent an upper limit of measured live-bed contraction scour, and when used to evaluate live-bed contraction scour in South Carolina, they will tend to overpredict scour depth for many site conditions, even excessively at times (figs. 68 and 74). However, the envelope curves will not predict scour that exceeds the upper bound of the measured field data. In contrast, predicted scour computed with the HEC-18 modified Laursen (1960) equation (Richardson and Davis, 2001) can have frequent underprediction and at times excessive overprediction (fig. 56), indicating that the South Carolina dimensionless and field envelope curves for live-bed contraction scour may provide more reasonable evaluations of scour potential for streams in the Piedmont and Coastal Plain of South Carolina. To provide a comparison of the performances of the HEC-18 equation (Richardson and Davis, 2001), the dimensionless envelope curves (fig. 67), and the field envelope curve (fig. $71 \mathrm{~A}$ ), a box plot of the prediction error for these three methods is shown in figure 76 . The box plot highlights the frequent underpredictions of the HEC-18 equation (Richardson and Davis, 2001). In contrast, the dimensionless envelope curves (fig. 67) and the field envelope curve (fig. 71A) have similar performances with infrequent underprediction and occasional excessive overprediction. Based on the box plots, it may be more prudent to use the dimensionless and (or) field envelope curves than HEC-18 to assess the potential for livebed contraction scour in the Coastal Plain and Piedmont of South Carolina.

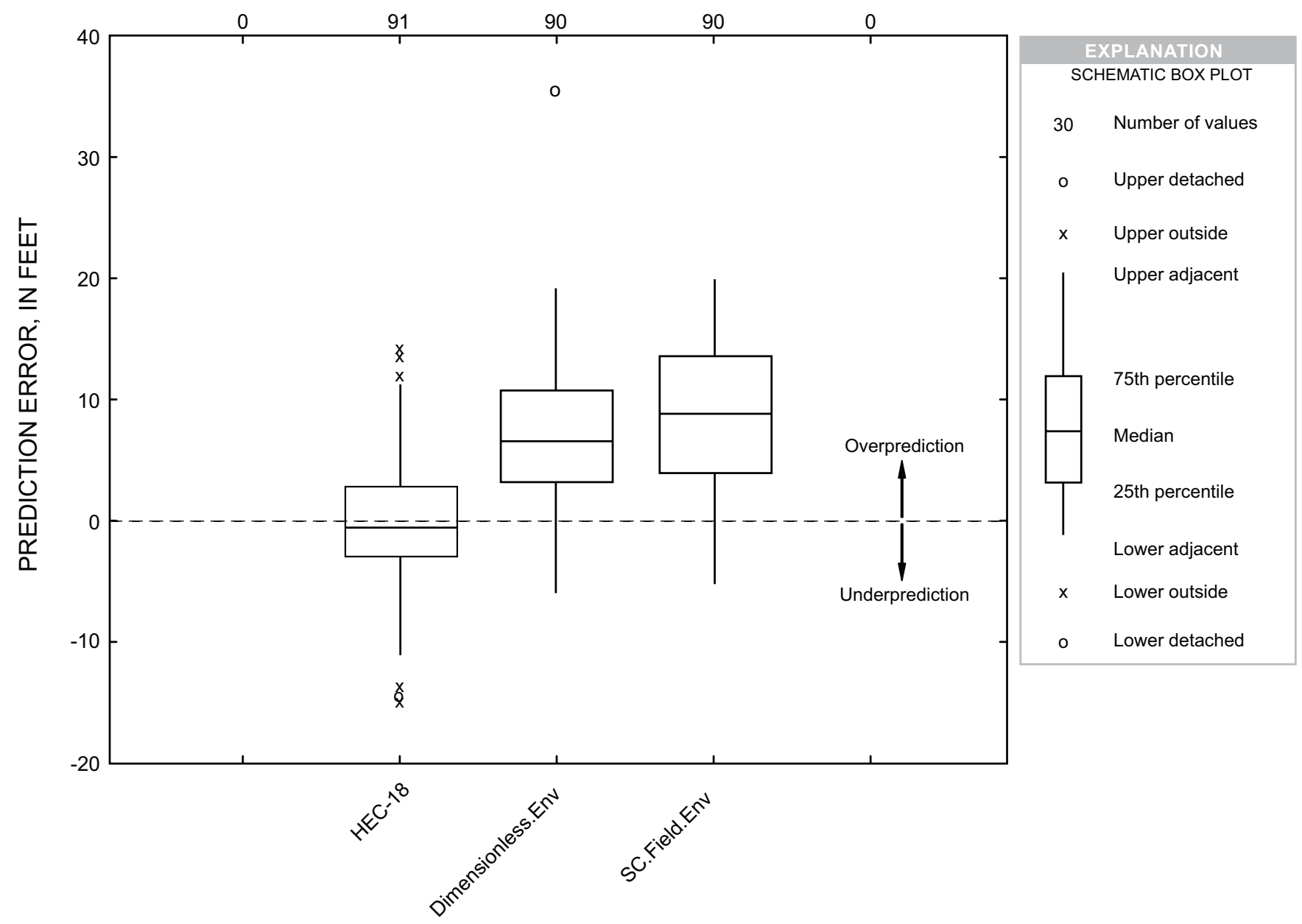

Figure 76. Box plots for the prediction error associated with the HEC-18 modified Laursen (1960) equation (Richardson and Davis, 2001), the dimensionless envelope curves in figure 67, and the South Carolina field envelope curve in figure $71 A$, when applied to field measurements from selected sites in South Carolina and selected data from the National Bridge Scour Database and Hayes (1996). 


\section{Guidance and Limitations for Assessing Live-Bed Contraction Scour}

The results of this investigation indicate that a significant measure of uncertainty can be associated with assessing the potential for live-bed contraction scour in South Carolina. The uncertainty extends to the Laursen (1960) equation (Richardson and Davis, 2001) as seen in figure 56. Additionally, because of the uncertainty associated with the field measurements (see report section "Data Limitations"), the dimensionless and field envelope curves (figs. 67 and 71, respectively) also have a measure of uncertainty. Therefore, using judgment is critical when estimating live-bed contraction-scour depths for bridges in South Carolina. The results of this investigation do not identify a definitive method for assessing live-bed contraction scour; however, the following guidance may provide some assistance.

\section{Channel Bends and Natural Constrictions of Flow}

Certain field conditions tend to increase the potential for live-bed contraction scour, and the identification of these features can help the practitioner qualitatively understand the potential for scour at a given site. As noted previously, general scour can create significant scour holes in the main channel and is caused by various field conditions including confluences (small or large), bends, natural channel constrictions, channel migration, debris, dune bedforms, and the natural thalweg meander. (Note: This is not intended to be an exhaustive list, and other features exist that will likely contribute to general scour.) When these field conditions occur at or near a bridge site, they are qualitative indicators that the potential for scour at the bridge may be larger than if these features were absent. (Note: Such field conditions do not assure that larger scour depths will occur, but only indicate the possibility of larger scour depths.) For more information regarding some of these types of general scour, refer to Breusers and Raudkivi (1991), Melville and Coleman (2000), Richardson and Davis (2001), and Richardson and others (2001). In the current investigation (2009), channel bends, natural channel or floodplain constrictions, and debris were field conditions that could be associated with large scour depths.

The two Coastal Plain sites that exceed the field envelope curve in figure $71 \mathrm{~A}$ are associated with channel bends, suggesting that the potential for scour increases under these conditions. Aerial photographs for both of these sites provide some perspective on the types of channel bends that may increase the potential for scour (fig. 77). The outside of the channel bend tends to have the largest amount of general scour, and piers located in this area tend to have more severe local scour. A channel bend, apart from the effects of a bridge constriction, will create general scour (Breusers and Raudkivi, 1991; Melville and Coleman, 2000; Richardson and Davis, 2001; Richardson and others, 2001). Therefore, even if a bridge does not create a significant contraction of flow, it will likely be subjected to general scour in the channel if it is located near a channel bend. Because the scouring effects of a channel bend can extend beyond the specific location of the bend, consideration must be given to channel bends near the bridge. While the interaction of a channel bend with a bridge constriction is difficult to quantify, it is important that the practitioner note the increased potential for scour resulting from a bend. Breusers and Raudkivi (1991), Melville and Coleman (2000), and Richardson and others (2001) provide limited qualitative and quantitative guidance on assessing scour associated with a channel bend; consulting these (or other engineering references) may be helpful when evaluating scour at a bridge that crosses near a channel bend.

It is interesting to note that the channel for the Little Pee Dee River at U.S. Route 501 (fig. 77A) has a natural constriction in addition to the channel bend. This natural channel constriction likely increases the scour potential at this site, emphasizing the need to take note of such field conditions when evaluating scour potential. In addition to a natural channel constriction, a floodplain could have a natural constriction that may constrict flow above and beyond that of the bridge. (This condition was previously noted for the bridge associated with the Hayes [1996] data.) This natural constriction of the floodplain will function similarly to a bridge constriction and will increase the potential for scour. In such cases, evaluating the geometric-contraction ratio associated with the natural constriction from the topographic map (or field data) and using it with the dimensionless or field envelope curves (figs. 67 and 71 , respectively), will provide some insights to the scour potential associated with the natural floodplain constriction.

\section{Debris}

The Piedmont site that exceeds the field envelope curve in figure $71 \mathrm{~A}$ is associated with debris, emphasizing that the potential for scour increases under these conditions. HEC-18 (Richardson and Davis, 2001) readily acknowledges that debris is a cause for increased scour, but current guidance for assessing the effects of debris is limited. (For more information on debris and scour, refer to Melville and Coleman [2000] and Bradley and others [2005].) Debris accumulation occurs frequently at bridges in South Carolina; therefore, the practitioner must give some consideration to this matter. Examples of debris accumulation are shown in figures 78 through 81 , indicating how massive the accumulations can become. To provide some perspective on the scour that may result from debris, some of the sites shown in figures 78 through 81 are discussed in more detail.

In August 1995, a major flood occurred on the Enoree River in the Piedmont of South Carolina (fig. 2). Figures 78 and 79 show debris accumulations at three sites along the Enoree River, including Roads S-112 and S-263 in Laurens County, and Road S-45 in Newberry County. During the August 1995 flood, these sites had flow magnitudes that were approximately $2.8,2.8$, and 0.7 times the 100 -year flow magnitude, respectively. (Note: These figures do not display 


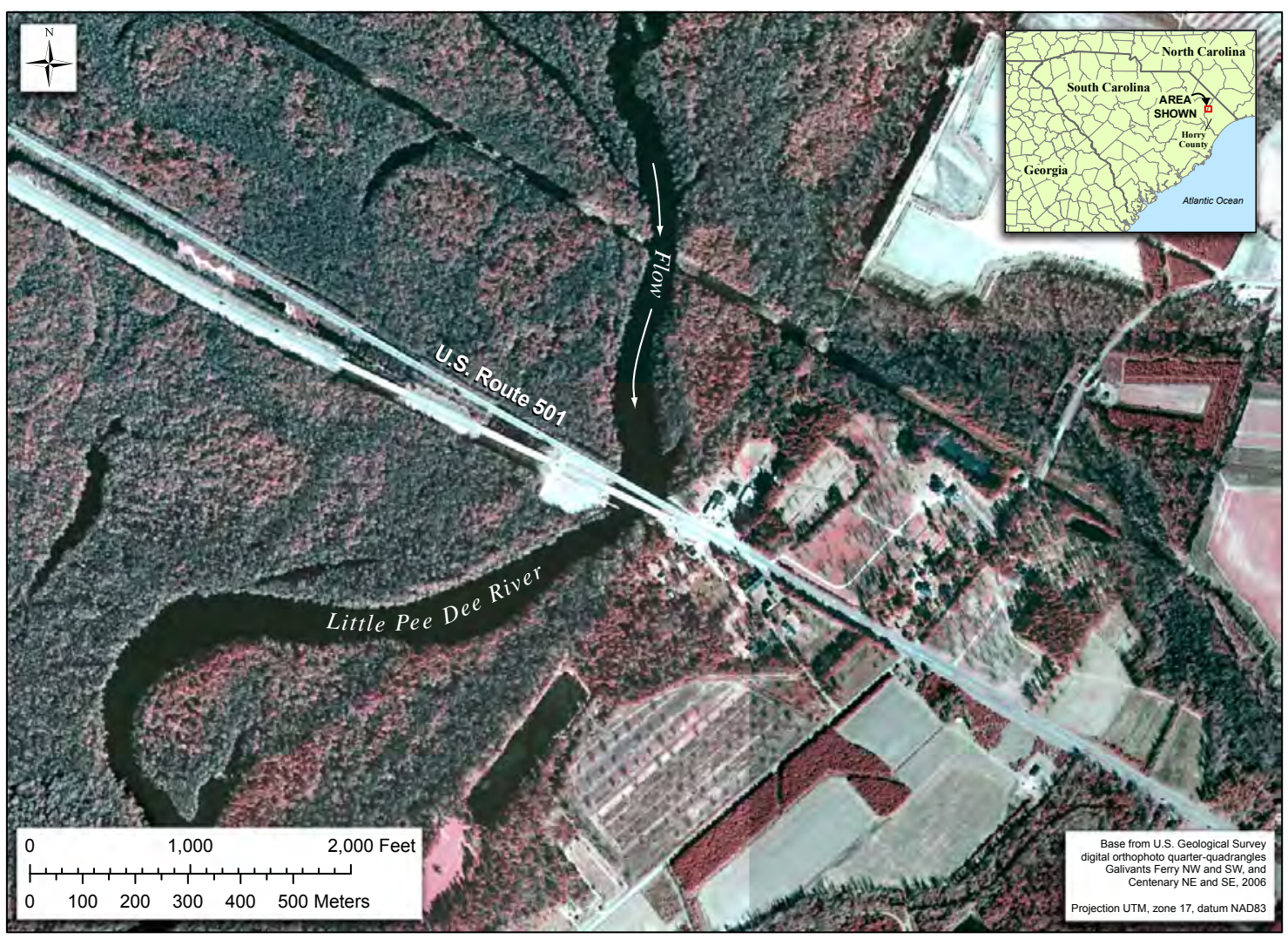

A.

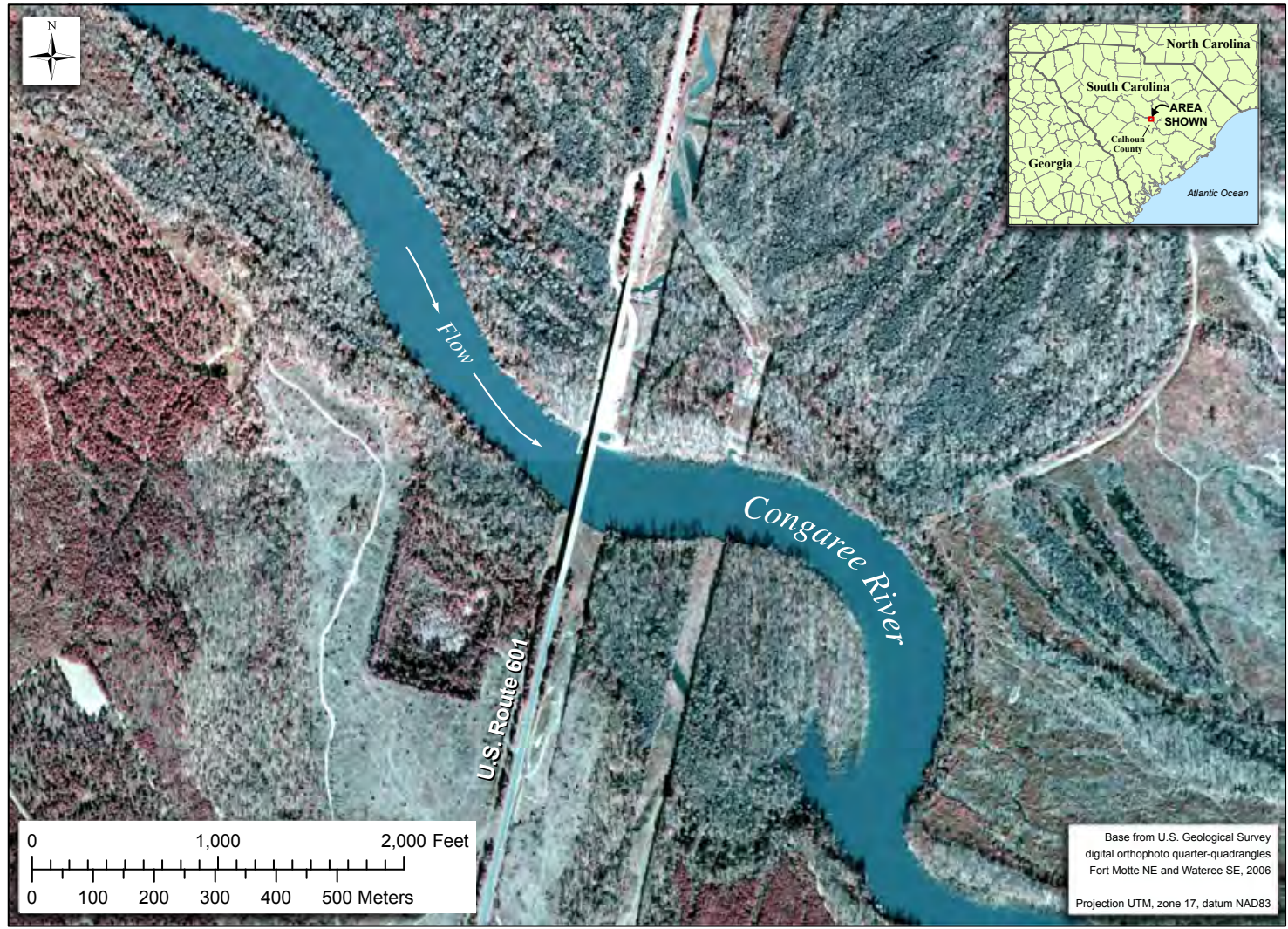

$B$.

Figure 77. Examples of channel bends that can increase scour potential at $(A)$ structure 262050110100 on U.S. Route 501 crossing the Little Pee Dee River in Horry County, South Carolina, and (B) structure 092060100300 on U.S. Route 601 crossing the Congaree River in Calhoun County, South Carolina. 


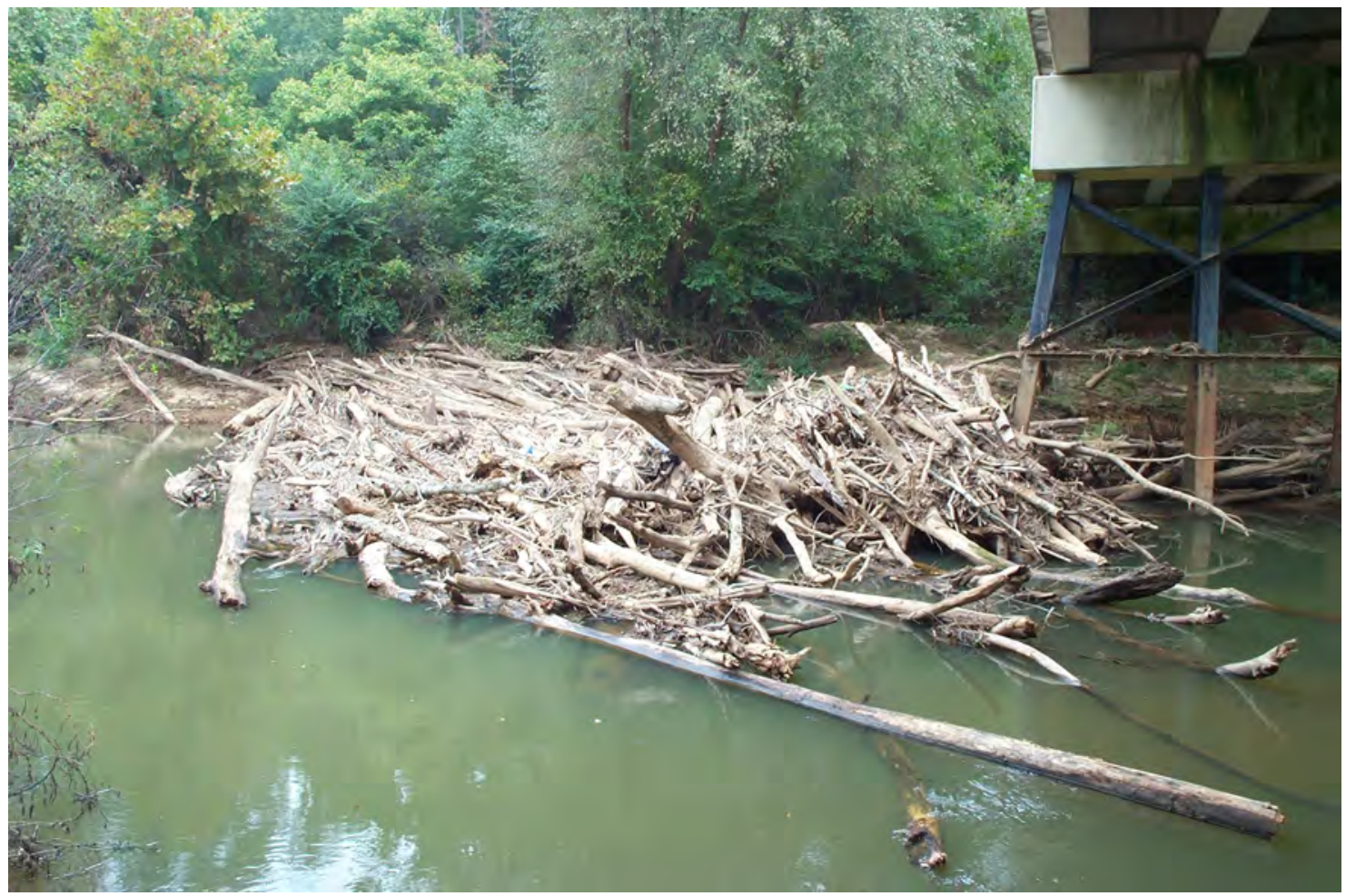

A.

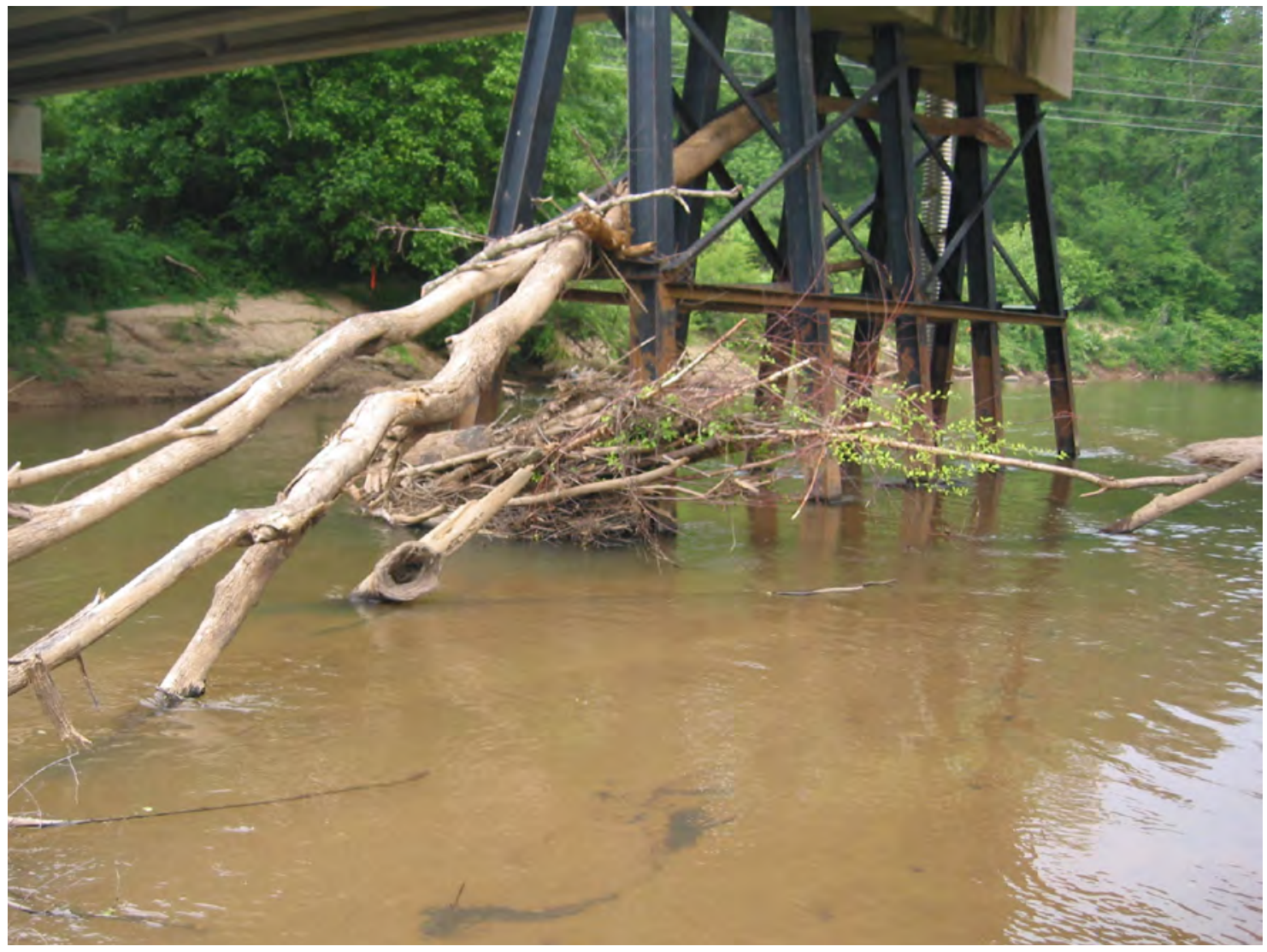

$B$.

Figure 78. Examples of debris accumulation that can increase scour potential at $(A)$ structure 307011200100 on Road S-112 crossing the Enoree River in Laurens County, South Carolina (October 9, 2002), and (B) structure 307026300100 on Road S-263 crossing the Enoree River in Laurens County, South Carolina (May 10, 2005). (Photography by the U.S. Geological Survey, South Carolina Water Science Center.) 


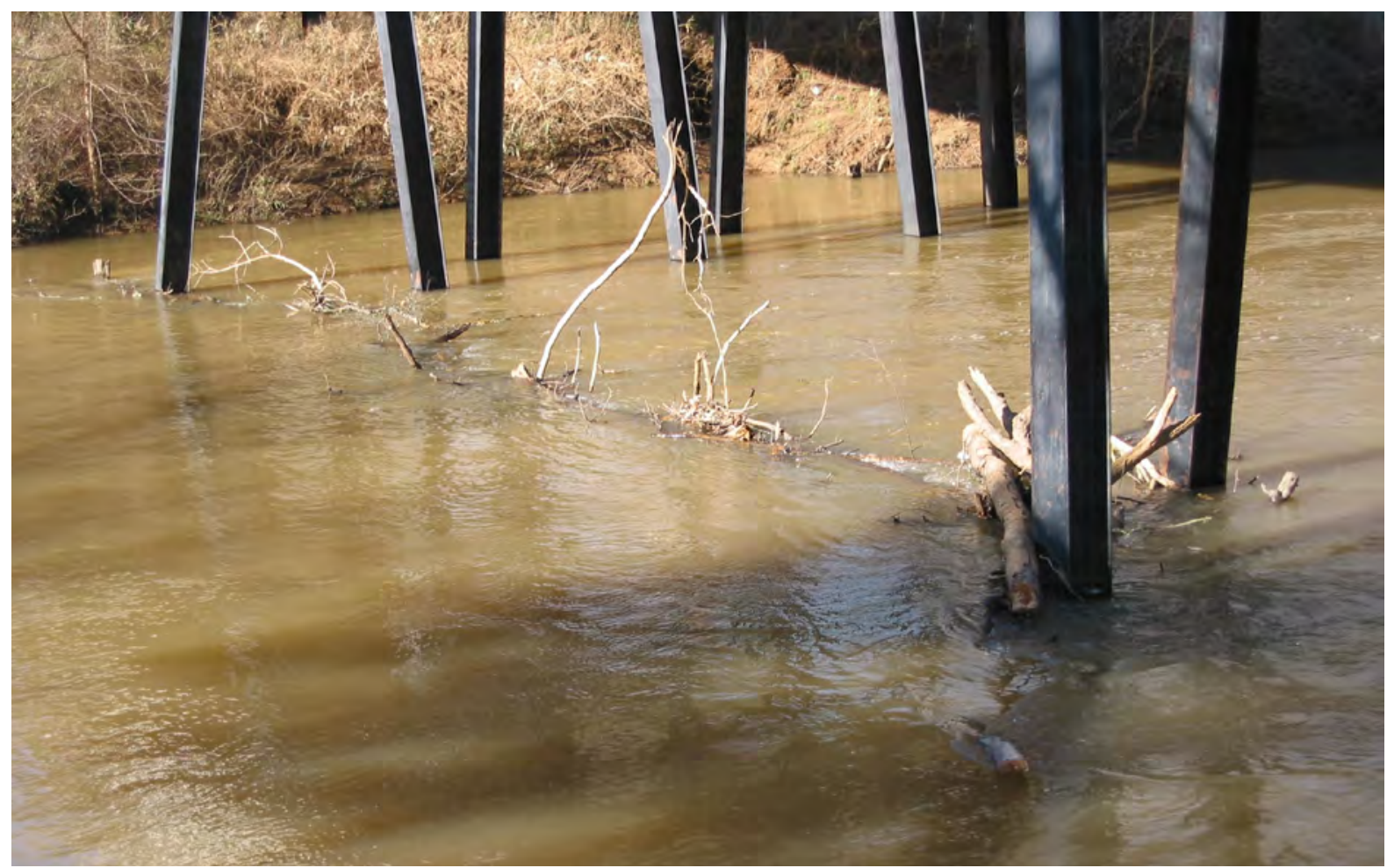

A.

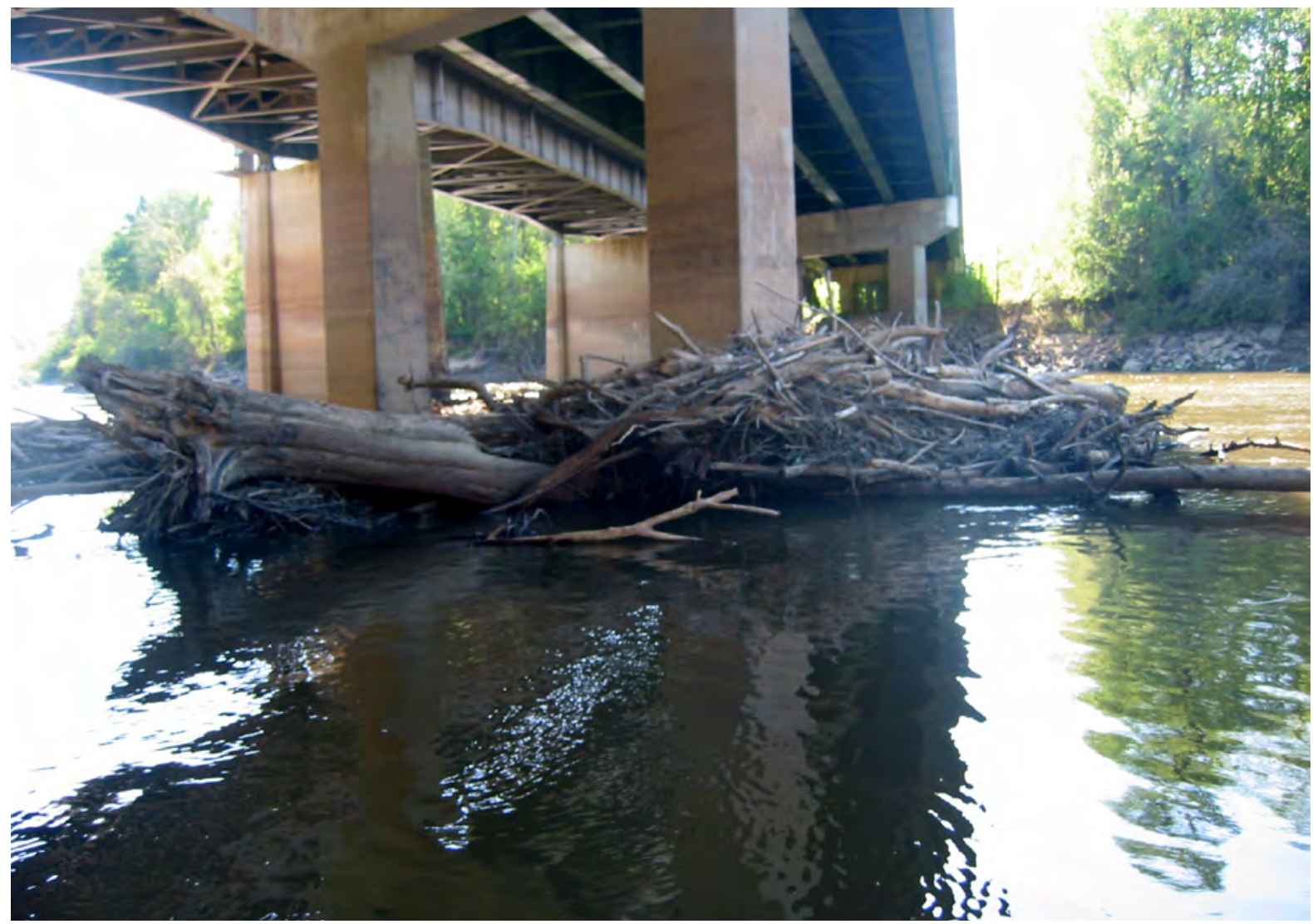

Figure 79. Examples of debris accumulation that can increase scour potential at $(A)$ structure 367004500100 on Road S-45 crossing the Enoree River in Newberry County, South Carolina (March 8, 2005), and (B) structure 342007620100 on U.S. Route 76 crossing the Great Pee Dee River in Marion County, South Carolina (April 11, 2006). (Photography by the U.S. Geological Survey, South Carolina Water Science Center.) 


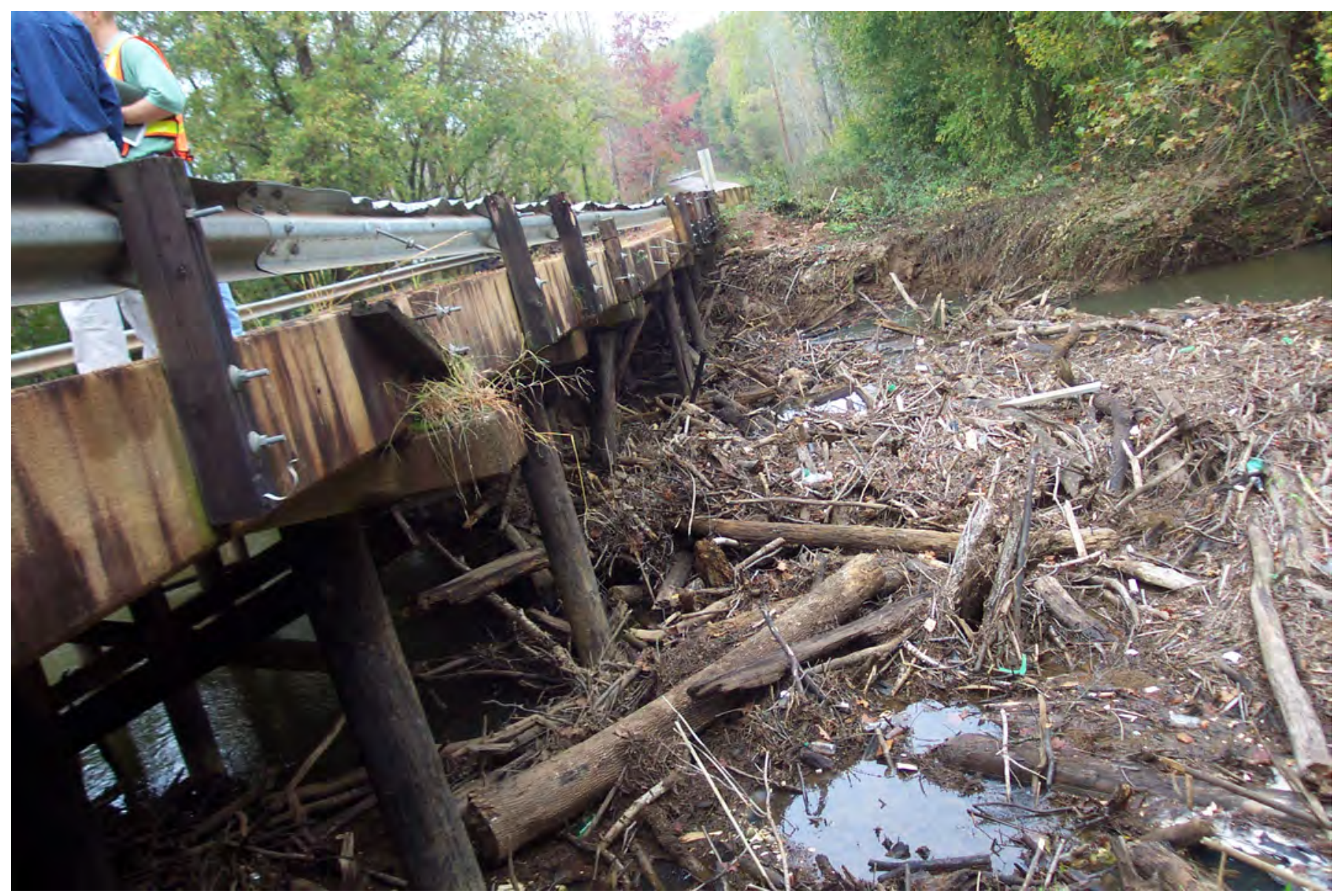

Figure 80. Example of debris accumulation that can increase scour potential at structure 427095600100 on Road S-956 crossing the North Pacolet River in Spartanburg County, South Carolina (October 9, 2004). (Photograph provided by the South Carolina Department of Transportation.)

the actual debris accumulation associated with the 1995 flood.) As can be seen in figures 78 and 79, these sites have pile bents located in the channel, and the bents contain battered piles that significantly increase the potential for debris accumulation. While the amount of debris accumulation at these sites during the August 1995 flood is not known, examples of debris accumulation at these sites as seen in figures 78 and 79 and the evidence of heavy debris accumulation at the S.C. Route 418 bridge during this flood (fig. 81) imply that significant debris accumulation did occur. Figures 82 through 84 provide some perspective on the magnitude of scour that can occur as a result of debris.

During the site visit of March 8, 2005, debris accumulation was observed at the Road S-45 bridge crossing the Enoree River in Newberry County (fig. 79A). The debris accumulation spanned the channel pile bents, but the full extent of the debris accumulation was not discernable because of submergence. The scour generated by the debris at the time of the site visit was approximately $5 \mathrm{ft}$, and the GPR data indicate that the maximum historic scour likely reached the rock line (fig. 82). It is assumed that the August 1995 flood created the maximum historic scour, and debris probably influenced the scour. A comparison of pre- and post-flood bridge cross sections at Roads S-112 and S-263 crossing the Enoree River (figs. 83 and 84 ) indicates that significant scour (approximately 9 and $16 \mathrm{ft}$, respectively) occurred at both sites during the August 1995 flood. The post-flood cross sections show that scour extended across the entire channel and that channel widening occurred, most notably at Road S-263. Also, the lower limits of the scour extended to rock at both sites.

In September 1945, a major flood occurred on the Great Pee Dee River in the Coastal Plain of South Carolina (fig. 2). Debris accumulations in 2006 at the Great Pee Dee River at U.S. Route 76 in Marion County indicate a significant potential for debris (fig. 79B). During the September 1945 flood, this site had flows approximately 1.4 times the 100 -year flow magnitude. The old westbound bridge was under construction at the time of the flood, and a post-flood survey of the channel was included in the plans (see SCDOT plans Docket Number 2134.201; fig. 85) (Note: The life span of the old westbound bridge was from approximately 1945 until 1992.) The plans indicate that the temporary trestle and coffer dam 


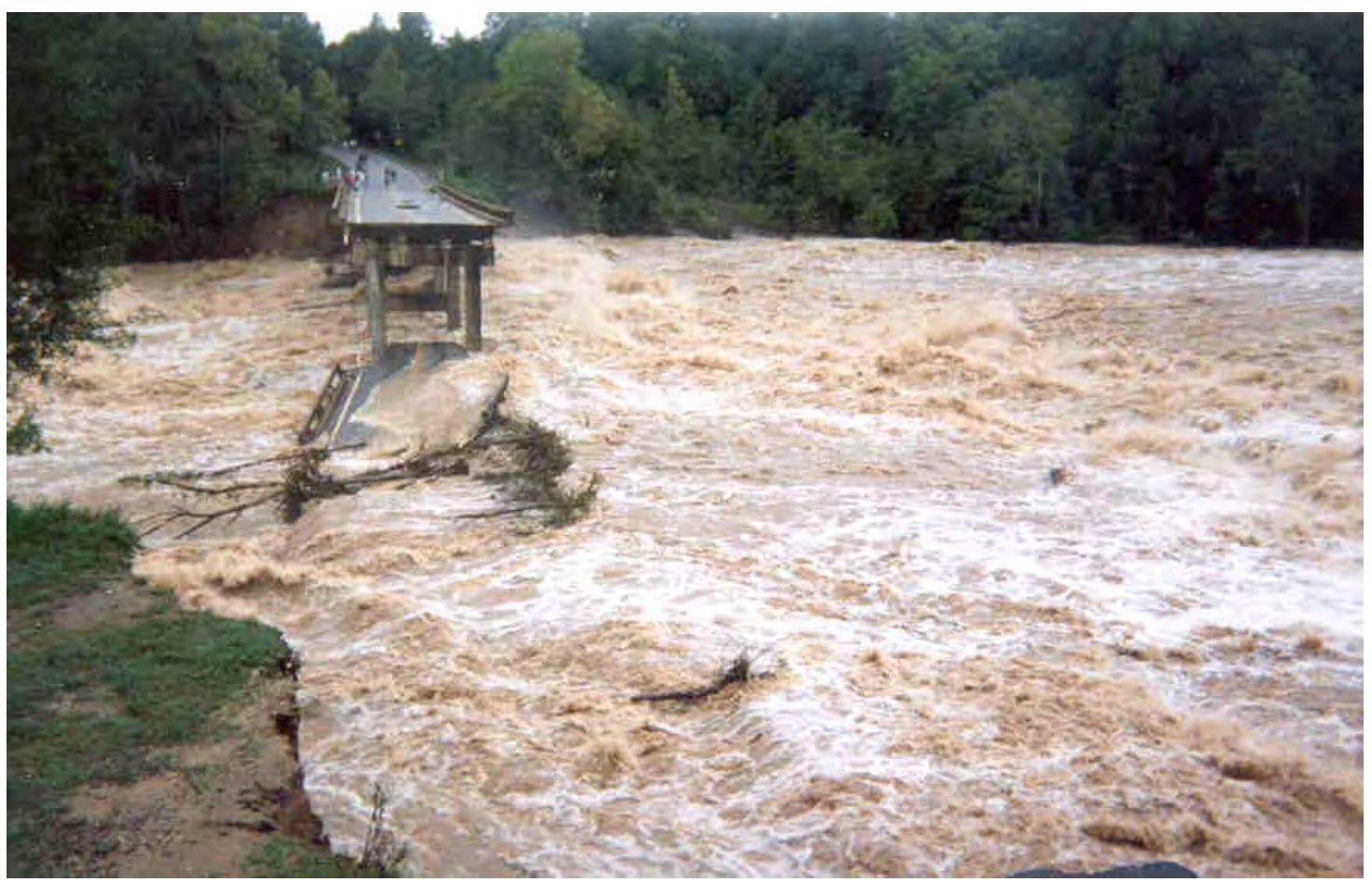

$A$.

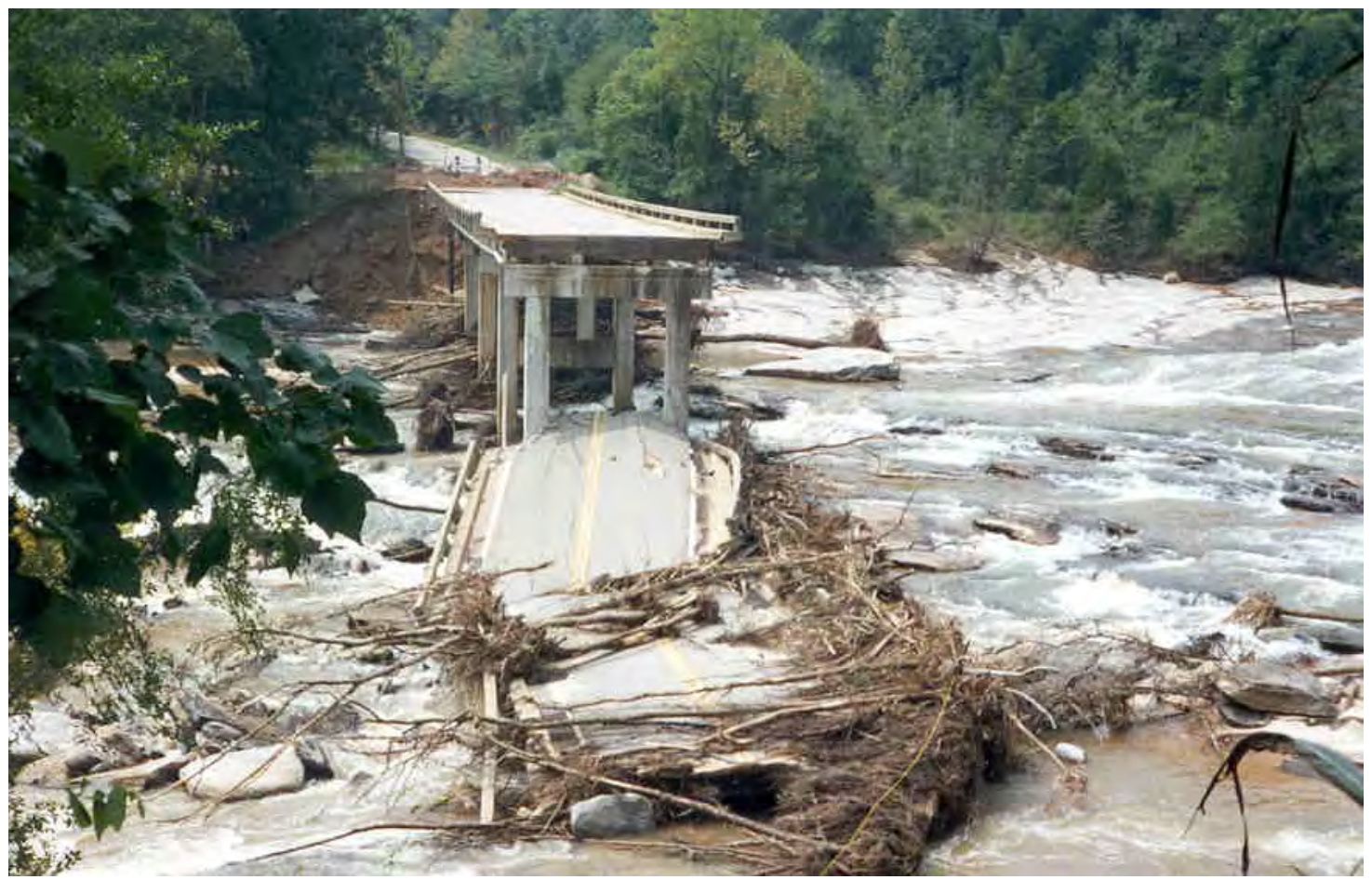

B.

Figure 81. Failure of structure 304041800300 on S.C. Route 418 crossing the Enoree River in Laurens County, South Carolina (A) during the August 1995 flood (August 27, 1995), and (B) after the flood (September 1995). (Photography by the U.S. Geological Survey, South Carolina Water Science Center.) 


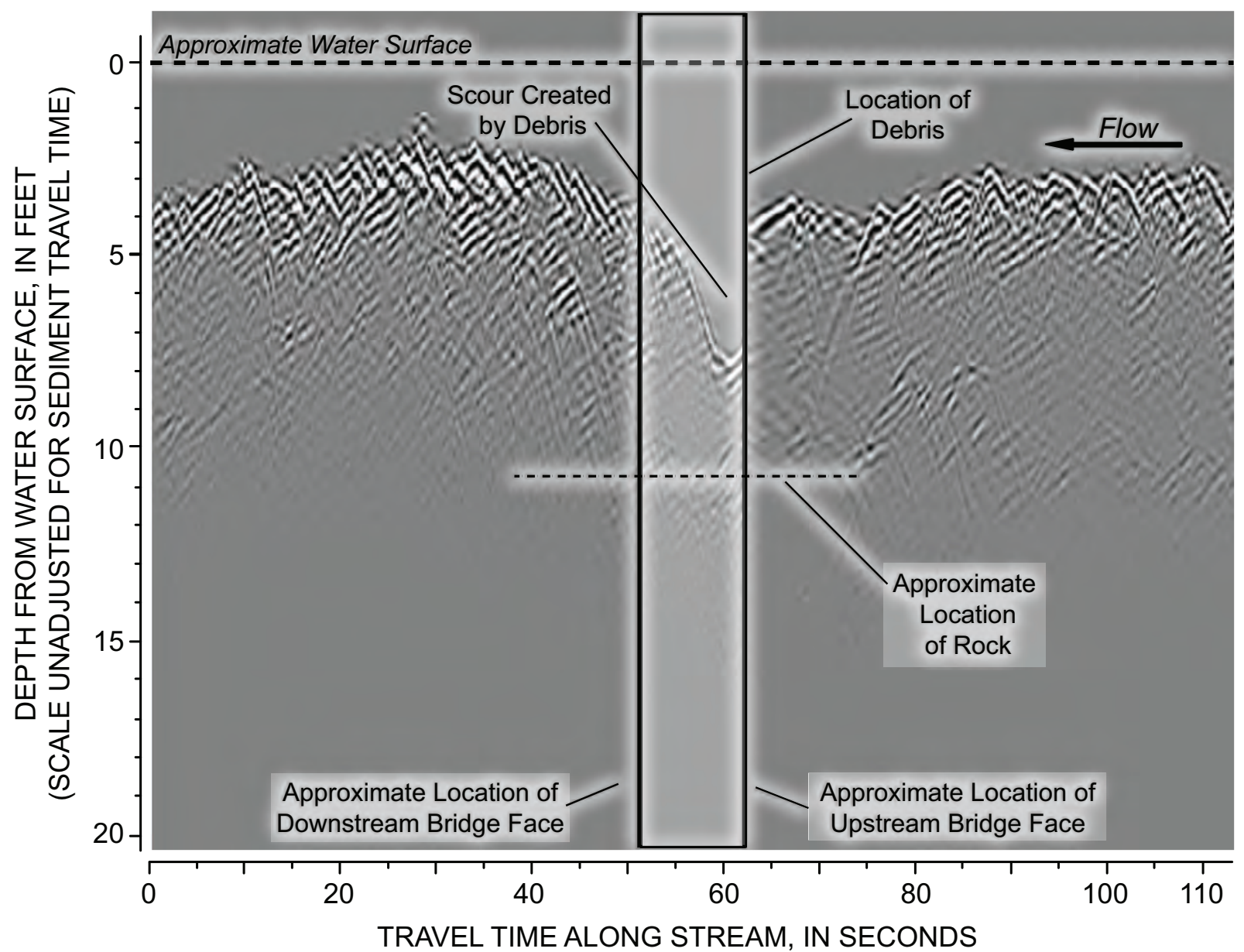

Figure 82. Example of ground-penetrating radar longitudinal profile showing scour created by debris accumulation at structure 367004500100 on Road S-45 crossing the Enoree River in Newberry County, South Carolina (March 8, 2005). (Depth scale through sediments is unadjusted and approximate only.)

contributed to the scour shown in figure 85 . Based on the potential for debris accumulation on this river, debris likely contributed to the scour. A comparison of pre- and post-flood bridge cross sections for this site (fig. 85) indicates that significant scour (approximately $9 \mathrm{ft}$ ) occurred during the September 1945 flood. The post-flood cross section shows that scour extended across the entire channel and that the lower limits of the scour approximately extended to the Black Creek formation, which is a scour-resistant clay.

Trends indicate that large scour depths do occur in the channels of South Carolina streams during large floods (figs. 82-85). The trends also indicate that debris likely is a significant factor in promoting this type of scour and must be considered when evaluating live-bed contraction-scour potential. Additionally, the trends indicate that significant channel widening can occur (fig. 84) during large floods, which may create adverse circumstances for bridge foundations on the floodplain near the channel banks. Benedict (2003, p. 115) also makes note of this potential problem and the need to use judgment when assessing scour at overbank piers near the channel banks.

\section{Elevation of Scour-Resistant Subsurface Soils}

Perhaps the most interesting and potentially useful trend in figures $82-85$ is that the extent of scour at these sites was limited by the scour-resistant subsurface soil. In the case of the three Piedmont sites along the Enoree River, the maximum historic scour was limited to bedrock. In general, the data from this investigation for Piedmont sites indicate that live-bed contraction scour in the channel does not exceed the scour-resistant subsurface soil layer identified in the SCDOT bridge-plan borings. Of the 35 live-bed contraction-scour measurements in the Piedmont, 3 had no boring data, 3 identified gravel, 7 identified clay, and 22 identified rock as the scour-resistant subsurface layer. These subsurface layers tend to be scour resistant and likely will not be eroded by live-bed contraction scour. Live-bed contraction scour for the Piedmont does not significantly cut into the scour-resistant layer (fig. 52). For the Piedmont, where scour data appear to cut into the scour-resistant layer, error from the GPR scour estimate and the boring interpretation may be to blame. In general, GPR data indicate that in the Piedmont, live-bed contraction 


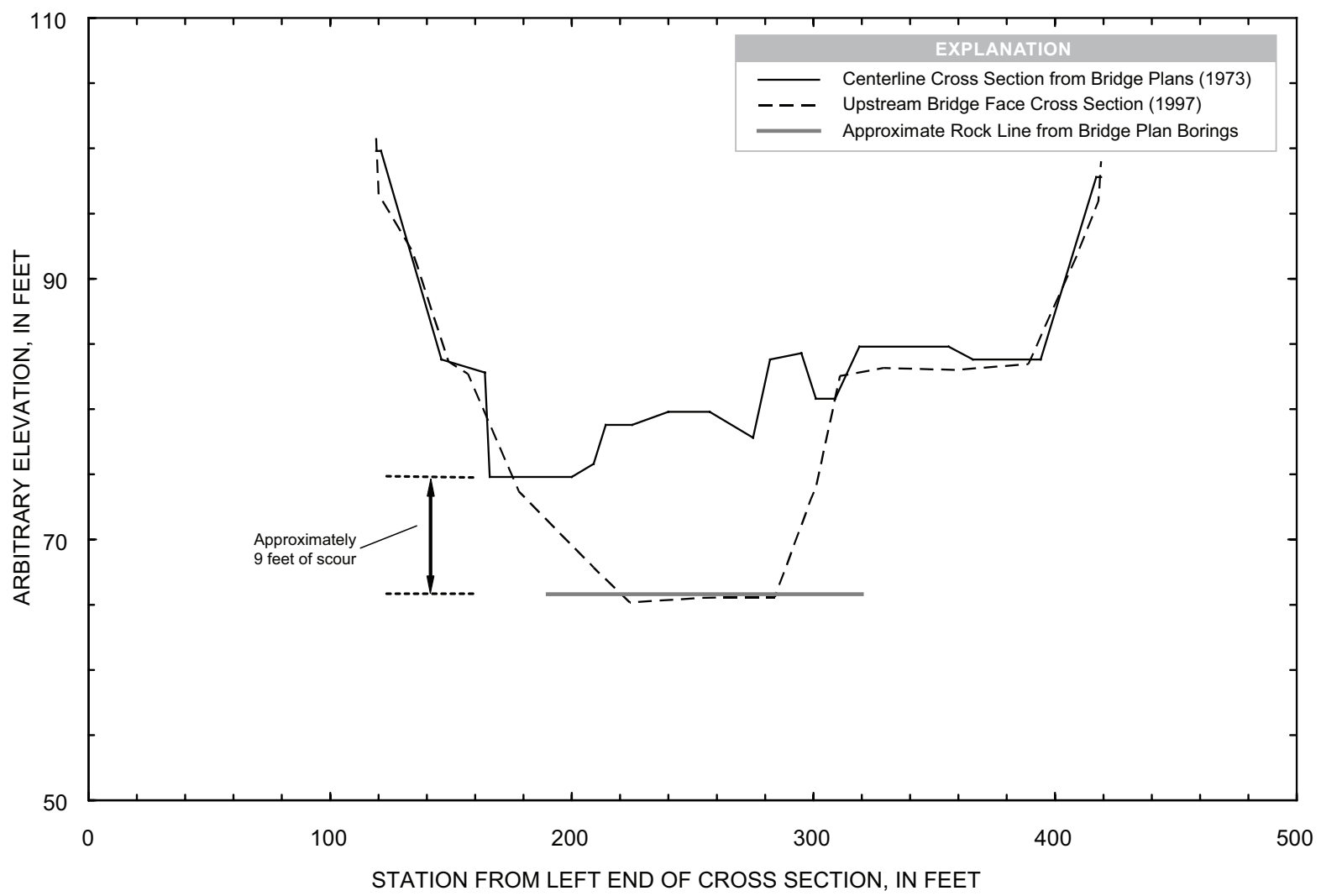

Figure 83. Scour from the August 1995 flood likely created by debris accumulation at structure 307011200100 on Road S-112 crossing the Enoree River in Laurens County, South Carolina.

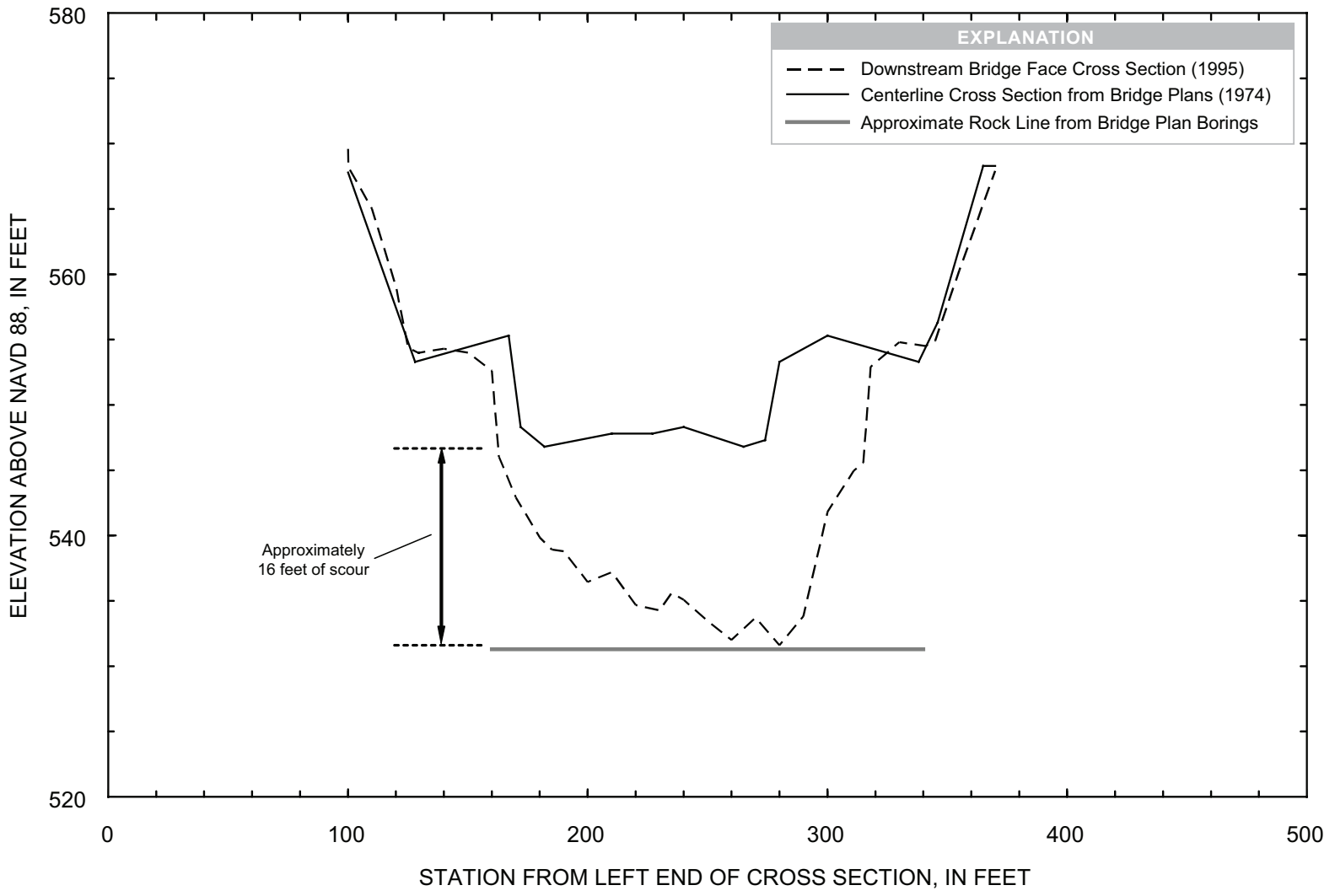

Figure 84. Scour from the August 1995 flood likely created by debris accumulation at structure 307026300100 on Road S-263 crossing the Enoree River in Laurens County, South Carolina. 


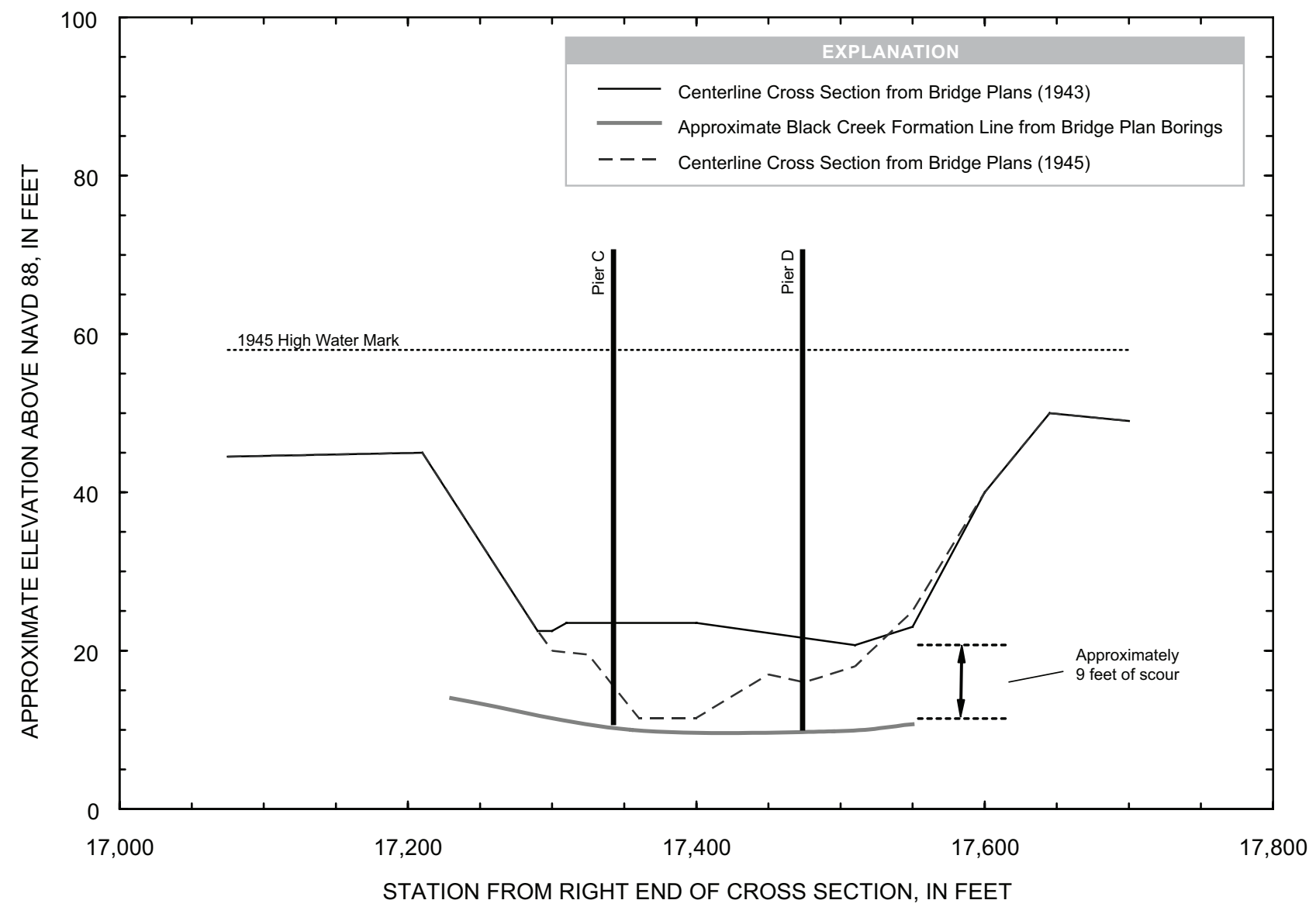

Figure 85. Scour from the September 1945 flood likely created by debris accumulation and coffer dam at structure 342007620100 on U.S. Route 76 crossing the Great Pee Dee River in Marion County, South Carolina.

scour will not cut beyond this scour-resistant layer, and this trend can be used to define the worst-case limits of scour in the Piedmont.

The trends of the Coastal Plain are slightly different from the Piedmont. Live-bed contraction scour will often cut into the subsurface layer (fig. 52). As with the Piedmont data, there is error in the Coastal Plain data and the relation shown on figure 52 will not be fully correct. However, because of the less resistant subsurface layers of the Coastal Plain, it is thought that the data on figure 52 reflect the general trends that occur in the Coastal Plain. Of the 57 live-bed contractionscour measurements in the Coastal Plain, the SCDOT borings indicated the following subsurface layers: 7 had no boring data, 5 identified gravel, 43 identified clay, and 2 identified rock as the scour-resistant subsurface layer. The clayey materials identified in the SCDOT borings range from soft clayey soils that are less resistant to scour to stiff clayey soils that are highly resistant to scour. In the case of the Great Pee Dee River at U.S. Route 76 (fig. 85), the subsurface layer (Black Creek Formation) is a hard clayey material that has a measure of resistance to scour, and the data suggest that scour did not penetrate that layer. In general, GPR data indicate that in the Coastal Plain, live-bed contraction scour can cut beyond the scour-resistant subsurface layer, but not excessively. The relation of the relative elevation differences between the bottom of the live-bed contraction-scour holes and the scour-resistant subsurface layers (the same data as shown in figure 52) to the geometric-contraction ratio is shown in figure 86 . While error exists in this relation because of the associated error in the data, the trend is helpful in showing that as the geometriccontraction ratio increases, the severity of cutting into the scour-resistant subsurface layer of the Coastal Plain streams also increases. The trend in figure 86 can be used to help qualitatively assess the potential for scouring the subsurface layers based on the geometric-contraction ratio. While the Coastal Plain trend is not as definitive in defining the worst-case limits of scour as does the Piedmont trend, the trends shown in figures 52 and 86 can be used to gain insights on the approximate worst-case limit for this region. 


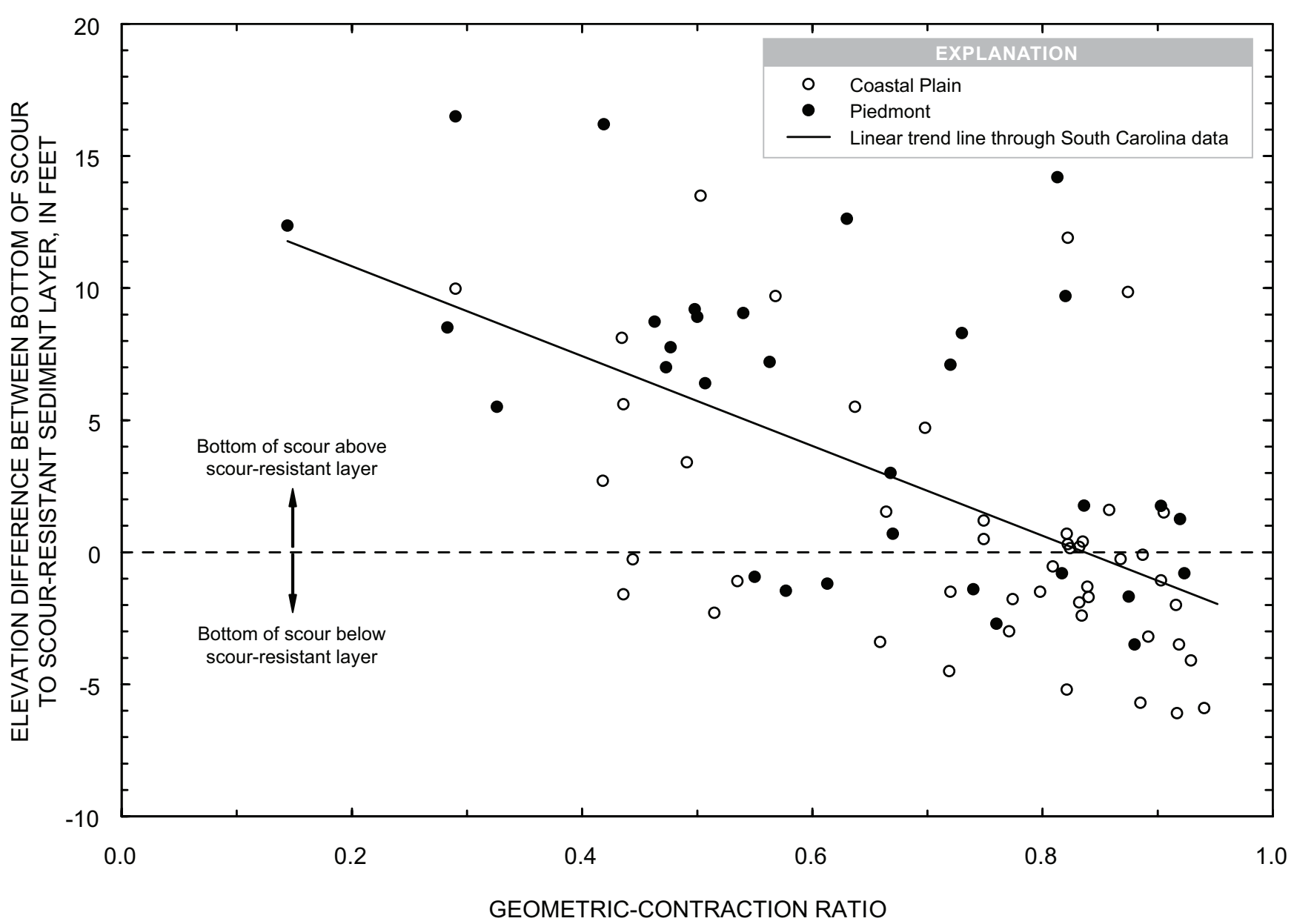

Figure 86. Relation of elevation differences between the bottom of live-bed contraction scour holes and the scour-resistant subsurface layer to the geometric-contraction ratio at selected sites in South Carolina.

\section{The Geometric-Contraction Ratio}

The relations in figures 67 and 71 clearly show that as the severity of the bridge contraction (or geometric-contraction ratio) increases, the upper bound of live-bed contraction scour also increases. This general trend has been confirmed in laboratory investigations of clear-water contraction scour (Das, 1973). Additionally, the simplified Laursen (1960) live-bed contraction-scour equation (eq. 11), as shown in figure 67 , confirms the general trend that contraction scour increases with the increasing of the geometric-contraction ratio. The geometric-contraction ratio, therefore, can be used to qualitatively assess the potential for live-bed contraction scour at a given bridge to be small or large.

\section{The Quantitative Assessment of Live-Bed Contraction Scour}

The results of this investigation do not identify a definitive method for qualitatively assessing the potential for livebed contraction scour. Therefore, the practitioner must use caution and judgment when qualitatively assessing this type of scour. The following guidance is suggested.

1. Initially evaluate live-bed contraction scour using the guidance of HEC-18 and the modified Laursen (1960) equation (Richardson and Davis, 2001; eq. 3).

2. Re-evaluate live-bed contraction scour (eq. 3), limiting the flow and width ratios $\left(Q_{2} / Q_{1}\right.$ and $W_{1} / W_{2}$, respectively) to 1 or greater. (See report section "Comparison of Measured and Predicted Contraction-Scour Depths Using the HEC-18 Equation.’) 
3. Re-evaluate live-bed contraction scour (eq. 3), limiting the flow ratio to 2 or greater and the width ratio to 1 or greater. (See report section "Dimensionless Envelope Curves for Live-Bed Contraction Scour.")

4. Evaluate live-bed contraction scour using the dimensionless envelope curves (eqs. 11-13; fig. 67), with equation 11 representing the worst-case theoretical scour for the simplifying assumptions applied to the Laursen (1960) equation and equations 12 (Coastal Plain) and 13 (Piedmont) representing the upper limits of the field data.

5. Evaluate live-bed contraction scour using the field envelope curves (eq. 14; fig. 71). (Use both envelope curves shown in figure 71.)

6. Review boring data and determine the approximate elevation of any scour-resistant subsurface layers. The degree of resistance of this layer must be evaluated to assess if scour can cut into this layer.

7. Determine the elevation of the appropriate reference surface and subtract the scour estimates from steps 1 through 5 to determine the elevation at the bottom of the scour hole.

8. Compare the elevations at the bottom of the scour hole from step 7 with the elevation of the scour-resistant subsurface layer; using judgment, select the most appropriate scour depth or adjust as deemed prudent. Factors that increase the potential for scour, as noted previously, should be considered when selecting a final estimate of scour.

9. Consider a factor of safety because of the uncertainty associated with these quantitative methods for assessing live-bed contraction scour.

\section{Limitations of the Envelope Curves}

The evaluation of live-bed contraction scour using the South Carolina dimensionless and (or) field envelope curves (figs. 67 and 71, respectively) should be limited to sites having similar characteristics to those of sites used in this study. To assist in this evaluation, characteristics of Coastal Plain and Piedmont sites can be compared to those presented in tables 5 and 6 and figures 3 and 4 that display the range and trend of characteristics for sites used in this investigation. The limitations of the envelope curves that were described in the previous sections should be carefully followed, and caution should be used when characteristics at a bridge approach the limits of the site characteristics used to develop the envelope curves. Because the envelope curves were developed from a limited sample of bridges in the Coastal Plain and Piedmont, scour depths could exceed the envelope curves. Additionally, the potential error and uncertainty associated with the livebed contraction-scour measurements (see report section "Data Limitations") introduce uncertainty into the envelope curves. The envelope curves, therefore, must be used with considerable caution. Applying a safety factor to the envelope curves would be prudent. When using the envelope curves, it is critical to properly estimate the channel flow depth and (or) the geometric-contraction ratio associated with the site of interest. Because the South Carolina dimensionless and field envelope curves (figs. 67 and 71, respectively) were derived from measured data, with many of the sites having historic flows close to the 100-year flow magnitude (fig. 73), the determination of hydraulic variables should be based on flows near this magnitude. To ensure that the geometric-contraction ratio is properly evaluated, various sources of data should be reviewed, including, but not limited to, topographic maps, hydraulic models, road plans, and field measurements. Because the envelope curves in figures 67 and 71 were developed using field data, with many sites having historic flows near the 100 -year flow magnitude, the envelope curves should not be used to evaluate live-bed contraction-scour depths for extreme conditions, such as the 500 -year flow.

\section{Selecting a Reference Surface for Live-Bed Contraction Scour}

In this study, the average thalweg elevation along the profile of the channel was used to determine live-bed contractionscour depths. The thalweg is defined as the low point of the channel bed and should represent the natural conditions unaffected by scour. This reference surface should be used when evaluating live-bed contraction scour with the South Carolina live-bed contraction-scour envelope curves (figs. 67 and 71). This reference surface can be determined by plotting the thalweg elevation at selected cross sections along the channel profile and then placing a best-fit line through that data to determine a reference surface. In many cases, defining the average thalweg elevation should not be a difficult task; however, the channel-bed topography is complex in some cases, making the determination of a reference surface more difficult. In such cases, judgment should be applied, bearing in mind that lower reference-surface elevations will produce lower scour-hole elevations and more conservative scour assessments.

\section{Pier Scour Within and the Location of Live-Bed Contraction Scour}

Because of the complex nature of live-bed contractionscour holes, isolating the components of contraction and pier scour was not always possible. Therefore, it is difficult to know whether the envelope curves in figures 67 and 71 represent only contraction scour or total scour. The uncertainty of the live-bed contraction-scour data requires the use of judgment when applying the envelope curves to account for any additional scour created by piers and pile bents. The complexity of scour patterns for live-bed contraction scour makes it difficult to determine the location at which the deepest scour will occur; therefore, for scour-assessment purposes, the scour-hole low point must be assumed to be located directly at the bridge. 


\section{The South Carolina Live-Bed Pier- and Contraction-Scour Database}

Selected data from this study have been compiled into the South Carolina Live-Bed Scour Database (SCLBSD), which can be viewed using Microsoft Access ${ }^{\circledR}$. The SCLBSD includes photographs, selected field data, variables used to compute predicted scour, predicted scour depths, limited basin characteristics, limited soil data, and selected hydraulic data estimated with the WSPRO model. These raw data were compiled in various data tables in the database, and automated forms have been developed to allow extraction of selected data for a bridge of interest. Appendix 1 contains a description of the SCLBSD automated forms, raw data tables, and variable definitions.

The SCLBSD was developed using Microsoft Access ${ }^{\circledR}$ 2007. The electronic file for the database requires approximately 850 megabytes of computer storage and is available for download from http://pubs.usgs.gov/sir/2009/5099/. To install the database, the file "SCLBSD.accdb" should be copied to the user's directory of choice. After the file is copied to the user's computer, the properties of the file should be changed from "Read-only" by (1) right clicking on the file and selecting "Properties" on the pop-up menu, (2) unselecting the "Readonly" option in the Properties menu box, and (3) clicking "OK" at the bottom of the menu box. To open the SCLBSD, the file "SCLBSD.mdb" should be opened in Microsoft Access $^{\circledR}$. Upon opening this file, the form-selection menu box with the heading, "The South Carolina Live-Bed Scour Database" will appear. This menu box lists four automated formsbridge information, pier-scour data for the historic flow, contraction-scour data for the historic flow, and photographic displays for each bridge. The pier- and contraction-scour forms are used to display the predicted scour for the historic flow, along with field measurements of scour and selected site information. The forms are retrieved by clicking on the appropriate button in the form-selection menu box. Near the top, right corner of each form, a drop-down menu is designated by a menu button with an arrow pointing downward. Clicking on this button will produce a list of bridges or scour observations included in this study. From this list, the user should select a bridge or scour observation of interest. Once a specific bridge or scour observation has been selected, the form will retrieve the data.

The SCLBSD is a valuable tool for use in investigating live-bed pier scour and contraction scour. The SCLBSD provides a tool for making site comparisons regarding scour at bridges in South Carolina. Sites under investigation but not included in the current study can be compared with sites in the SCLBSD to gain insights about the range of anticipated scour depths. The SCLBSD also provides a source of data to evaluate various methods for predicting live-bed pier and contraction scour. Most equations for predicting scour are driven by hydraulic variables, such as flow depth and velocity. These variables can be extracted from the SCLBSD and used in various equations to compute predicted scour depths. The predicted scour depths can then be compared with measured scour and the field-data envelope curves to evaluate the chosen equation's performance. (Hydraulic data in the SCLBSD may need to be manipulated to obtain specific variables required for a given predictive equation.)

The hydraulic data in the SCLBSD were generated from a model and, therefore, do not necessarily represent the flow conditions that created the measured scour. As a result, some error is likely to be introduced into the comparison of predicted and measured scour because of inaccuracies in the hydraulic data. However, the numerous data points in the SCLBSD do allow such comparisons to show the general trends of a predictive equation and provide some indication of the equation's performance.

The SCLBSD provides only limited information at each study site and, therefore, cannot be relied on to provide a complete understanding of the sites. If more detailed information is required to understand conditions at a given site, other data sources should be consulted, such as topographic maps and bridge plans. Under certain circumstances, site visits may be required to gain a full appreciation of the measured scour and the conditions that created it. 


\section{Summary}

The U.S. Geological Survey, in cooperation with the South Carolina Department of Transportation, used groundpenetrating radar to collect measurements of live-bed pier scour and contraction scour at 78 bridges in the Piedmont and Coastal Plain Physiographic Provinces of South Carolina. The 151 measurements of live-bed pier-scour depth ranged from 1.7 to $16.9 \mathrm{ft}$, and the 89 measurements of live-bed contraction-scour depth ranged from 0 to $17.1 \mathrm{ft}$. The collected data represent the maximum live-bed pier-scour and (or) livebed contraction-scour depths that have occurred at selected bridges since construction. While ground-penetrating radar is a useful tool for investigating historic scour patterns, the data interpretation process introduces uncertainty and error into the estimate of scour depths. This uncertainty should be kept in mind when reviewing relations in the data. Flow conditions creating the measured scour are not known. To estimate the flow conditions that may have created the measured scour, the maximum historic flows based on gage data or indirect measurements were estimated at 61 of the bridges. At the remaining 17 bridges where gage records were not available, the 100-year flow was used to approximate maximum historic flows that may have created the scour. Of the 61 sites having historic flow records, 48 had maximum historic flows equaling or exceeding approximately 70 percent of the 100 -year flow magnitude; 27 sites had maximum historic flows approximately equaling or exceeding the 100 -year flow magnitude. Because the collected data include a number of sites where relatively large flows have occurred, the data can provide insights for the range of anticipated scour depths at bridges with similar site characteristics.

To further understand hydraulic conditions that may have created the measured scour, hydraulic models were developed for each site using the one-dimensional step-backwater model, Water Surface-PROfile (WSPRO). The maximum historic flows, based on gage data or approximated with the 100-year flow, were used in the WSPRO models. Hydraulic data generated from the WSPRO models were used to compute predicted scour with methods presented in the Federal Highway Administration Hydraulic Engineering Circular No. 18 (HEC-18). A comparison of predicted and measured scour showed that predicted pier-scour depths generally exceeded the measured pier-scour depths, and at times predicted pier-scour depths were excessive (overpredictions were as large as $23.1 \mathrm{ft}$ ). A comparison of predicted and measured scour for live-bed contraction-scour depths showed that predicted scour could at times be excessive (overpredictions were as large as $14.3 \mathrm{ft}$ ), but often observed contraction scour was underpredicted.

Modeled hydraulic data, predicted scour data, and field data were compiled into a database and were used to investigate relations that may help explain live-bed pier scour in South Carolina. The South Carolina live-bed pier-scour field data were compared with laboratory data and field data from the U.S. Geological Survey National Bridge Scour Database, and the similarities indicated that the South Carolina field data are capturing the trends associated with live-bed pier scour. Variables determined to be influential in creating pier scour in laboratory studies were investigated to understand their influence on the South Carolina field data. Many of these variables appeared to be weak explanatory variables under the field conditions found in South Carolina. The strongest explanatory variable for live-bed pier scour in South Carolina appeared to be pier width. Based on this trend, an envelope curve was developed using pier width as the primary explanatory variable. The envelope curve is simple to apply and can be used to obtain a quick evaluation of the upper bound of live-bed pier scour in South Carolina.

Limited field data from the U.S. Geological Survey National Bridge Scour Database and other investigations were used to supplement the South Carolina live-bed contractionscour data. Various relations within the data were investigated, and several envelope curves for evaluating the ranges of livebed contraction-scour depths in the Coastal Plain and Piedmont Physiographic Provinces of South Carolina were developed. The envelope curves use the geometric-contraction ratio as the primary explanatory variable. The envelope curves are simple to apply and can be used to obtain a quick evaluation of the upper bound of live-bed contraction scour in South Carolina.

Although the field-derived envelope curves are valuable tools for assessing live-bed scour potential in South Carolina, the limitations of the envelope curves must be carefully considered, and they should not be used at sites outside the range of data for which they were developed. General guidance for assessing the potential for live-bed pier and contraction scour in South Carolina are provided in the report.

Data for each bridge have been compiled into a database that includes photographs, measured scour depths, predicted scour depths, limited basin characteristics, limited soil data, and estimated hydraulic data. The database can be used to compare sites that have similar characteristics when evaluating the potential for scour. In addition, the database provides a large source of field data that can be used to evaluate the performance of various theoretical methods for predicting live-bed pier and contraction scour. 


\section{Selected References}

Basak, V., Baslamisli, Y., and Ergun, O., 1977, Local scour depths around circular pier groups aligned with the flow: Turkey General Directorate of State Hydraulic Works Report No. 641. (In Turkish.) (as cited in Yanmaz and Cicekdag [2001])

Bedient, P.B., and Huber, W.C., 1988, Hydrology and floodplain analysis: Reading, Mass., Addison-Wesley Publishing Co., $650 \mathrm{p}$.

Benedict, S.T., 2003, Clear-water abutment and contraction scour in the Coastal Plain and Piedmont Provinces of South Carolina, 1996-99: U.S. Geological Survey WaterResources Investigations Report 03-4064, 137 p.

Benedict, S.T., Abrahamsen, T.A., and Caldwell, A.W., 2007, Collection of historic live-bed scour data at selected bridges in South Carolina using ground-penetrating radar, in The World Environmental and Water Resources Congress 2007, Tampa, Florida, 2007, Proceedings: Reston, Virginia, American Society of Civil Engineers, p. 1-11.

Benedict, S.T., and Caldwell, A.W., 2006, Development and evaluation of clear-water pier and contraction scour envelope curves in the Coastal Plain and Piedmont Provinces of South Carolina: U.S. Geological Survey Scientific Investigations Report 2005-5289, 98 p.

Bohman, L.R., 1990, Determination of flood hydrographs for streams in South Carolina-Volume 1. Simulation of flood hydrographs for rural watersheds in South Carolina: U.S. Geological Survey Water-Resources Investigations Report 89-4087, 53 p.

Bohman, L.R., 1992, Determination of flood hydrographs for streams in South Carolina-Volume 2. Estimation of peakdischarge frequency, runoff volumes, and flood hydrographs for urban watersheds: U.S. Geological Survey WaterResources Investigations Report 92-4040, 79 p.

Bradley, J.B., Richards, D.L., Bahner, C.D., 2005, Debris control structures-evaluation and countermeasures: Federal Highway Administration Hydraulic Engineering Circular No. 9, Publication No. FHWA-IF-04-016, 179 p.

Breusers, H.N.C., Nicollet, G., and Shen, H.W., 1977, Local scour around cylindrical piers: Journal of Hydraulic Research, v. 15, no. 3, p. 211-252.

Breusers, H.N.C., and Raudkivi, A.J., 1991, Scouring: Rotterdam, A.A. Balkema, 143 p.

Chabert, J., and Engeldinger, P., 1956, Etude des affouillements autour des piles des ponts: Chatou, France, Laboratoire d'Hydraulique. (as cited in Yanmaz and Cicekdag [2001])
Das, B.P., 1973, Bed scour at end-dump channel constrictions: Journal of the Hydraulics Division, v. 99, no. 12, p. 2273-2291.

Dongol, D.M.S., 1993, Local scour at bridge abutments: New Zealand, University of Auckland, School of Engineering Report no. 544, 410 p.

Ettema, Robert, Melville, B.W., and Barkdoll, Brian, 1998, Scale effect in pier-scour experiments: Journal of Hydraulic Engineering, v. 124, no. 6, p. 639-642.

Feaster, T.D., and Tasker, G.D., 2002, Techniques for estimating the magnitude and frequency of floods in rural basins of South Carolina, 1999: U.S. Geological Survey WaterResources Investigation Report 02-4140, 34 p.

Gill, M.A., 1981, Bed erosion in rectangular long contraction: Journal of the Hydraulics Division, v. 107, no. 3, p. 273-284.

Guimaraes, W.B., and Bohman, L.R., 1992, Techniques for estimating magnitude and frequency of floods in South Carolina, 1988: U.S. Geological Survey Water-Resources Investigations Report 91-4157, 174 p.

Hancu, S., 1971, Sur le calcul des affouillements locaux dans la zone des piles de ponts, in Proceedings of the 14th International Association for Hydraulic Research Congress, v. 3, p. 299-313. (In French.) (as cited in Yanmaz and Cicekdag [2001])

Hayes, D.C., 1996, Scour at bridges in Delaware, Maryland, and Virginia: U.S. Geological Survey Water-Resources Investigations Report 96-4089, 35 p.

Hurley, N.M., Jr., 1996, Assessment of scour-critical data collected at selected bridges and culverts in South Carolina, 1990-92: U.S. Geological Survey Open-File Report 96-350, 119 p.

Jain, S.C., and Fischer, E.E., 1979, Scour around circular bridge piers at high Froude numbers: Federal Highway Administration Report FHWA-RD-79-104, available from NTIS, 5285 Port Royal Road, Springfield, Virginia 22161. (as cited in Yanmaz and Cicekdag [2001])

Landers, M.N., and Mueller, D.S., 1993, Reference surfaces for bridge scour depths: Proceedings of the 1993 National Conference on Hydraulic Engineering, American Society of Civil Engineers, v. 2, p. 2075-2080.

Laursen, E.M., 1960, Scour at bridge crossings: Journal of the Hydraulics Division, American Society of Civil Engineers, v. 89 , no. 3 .

Laursen, E.M., 1963, An analysis of relief bridge scour: Journal of the Hydraulics Division, v. 92, no. 3.

Laursen, E.M., and Toch, A., 1956, Scour around bridge piers and abutments: Iowa Highway Research Board, Bulletin No. 4, 60 p. 
MALA GeoScience. RAMAC GroundVision, Software Manual, version 1.3, $37 \mathrm{p}$.

Melville, B.W., 1984, Live-bed scour at bridge piers: Journal of Hydraulic Engineering, v. 110, no. 9, p. 1234-1247. (as cited in Yanmaz and Cicekdag [2001])

Melville, B.W., and Coleman, S.E., 2000, Bridge scour: Highlands, Colorado, Water Resources Publications, $550 \mathrm{p}$.

Mueller, D.S., 1996, Local scour at bridge piers in nonuniform sediment under dynamic conditions: Fort Collins, Colorado State University, Civil Engineering Department, Ph.D. dissertation, $212 \mathrm{p}$.

Mueller, D.S., and Wagner, C.R., 2005, Field observations and evaluations of streambed scour at bridges: Federal Highway Administration, Publication FHWA-RD-03-052, 122 p.

National Cooperative Highway Research Program, 1970, Scour at bridge waterways: Washington, D.C., Highway Research Board, National Academy of Sciences, $37 \mathrm{p}$.

Neill, C.R., 1964, Local scour around bridge piers-a comparative analysis of model experiments and field data: Highway and River Engineering Division, Research Council of Alberta, 48 p.

Placzek, Gary, and Haeni, F.P., 1995, Surface-geophysical techniques used to detect existing and infilled scour holes near bridge piers: U.S. Geological Survey Water-Resources Investigations Report 95-4009, 44 p.

Pope, B.F., Tasker, G.D., and Robbins, J.C., 2001, Estimating magnitude and frequency of floods in rural basins of North Carolina (revised): U.S. Geological Survey WaterResources Investigations Report 01-4207, 44 p.

Richardson, E.V., and Davis, S.R., 2001, Evaluating scour at bridges ( $4^{\text {th }}$ ed.): Federal Highway Administration Hydraulic Engineering Circular No. 18, Publication No. FHWA NHI 01-001, $378 \mathrm{p}$.

Richardson, E.V., Harrison, L.J, and Davis, S.R., 1991, Evaluating scour at bridges: Federal Highway Administration Hydraulic Engineering Circular No. 18, Publication No. FHWA-IP-90-017, 105 p.

Richardson, E.V., Harrison, L.J., Richardson, J.R., and Davis, S.R., 1993, Evaluating scour at bridges ( $2^{\text {nd }}$ ed.): Federal Highway Administration Hydraulic Engineering Circular No. 18, Publication No. FHWA-IP-90-017, 131 p.

Richardson, E.V., Simons, D.B., and Lagasse, P.F., 2001, River engineering for highway encroachments: Federal Highway Administration Hydraulic Design Series Number 6, Publication No. FHWA NHI 01-004, 644 p.

Shearman, J.O., 1990, User's manual for WSPRO-A computer model for water-surface profile computations: Federal Highway Administration, Report No. FHWA-IP-89-027, $175 \mathrm{p}$.
Shen, H.W., Schneider, V.R., and Karaki, S., 1966, Mechanics of local scour, data supplement. Colorado State University CER 66-67 HWS-VRS-SK-27, prepared for U.S. Department of Commerce, Bureau of Public Roads, Office of Research and Development, Structures and Applied Mechanics Division under Contract No. CPR 11-8022. (as cited in Yanmaz and Cicekdag [2001])

South Carolina Department Of Transportation road plans Docket Number 2134.201

Tarapore, Z.S., 1962, A theoretical and experimental determination of the erosion patterns caused by obstructions in an alluvial channel with particular reference to a vertical cylindrical pier: University of Minnesota, Ph.D. thesis. (as cited in Yanmaz and Cicekdag [2001])

U.S. Geological Survey, 2001, National Bridge Scour Database, accessed October 15, 2008, at http://water.usgs.gov/ osw/techniques/bs/BSDMS/index.htm

Wagner, C.R., Mueller, D.S., Parola, A.C., Hagerty, D.J., and Benedict, S.T., 2006, Scour at contracted bridges: Transportation Research Board, National Cooperative Highway Research Program Document 83 (Project 24-14), 299 p., accessed December 19, 2008, at http://onlinepubs.trb.org/ onlinepubs/nchrp/nchrp_w83.pdf

Webb, D.J., Anderson N.L., Newton Tim, and Cardimona, Steve, 2000, Bridge scour-Application of ground penetrating radar: Federal Highway Administration and Missouri Department of Transportation special publication, accessed December 6, 2006, at http://campus.umr.edu/utc/pubs/ conf/2000/scour.pdf

White, W.R., 1975, Scour around bridge piers in steep streams, in Proceedings of the 16th IAHR Congress, Sao Paulo, Brazil, v. 2, p. 279-284. (as cited in Yanmaz and Cicekdag [2001])

Yang, T.Y., 1996, Sediment transport theory and practice: New York, McGraw-Hill, 396 p.

Yanmaz, A.M., and Cicekdag, Ozgur, 2001, Composite reliability model for local scour around cylindrical bridge piers: Canadian Journal of Civil Engineering, v. 28, no. 3, p. $520-535$.

Zalants, M.G., 1990, Low-flow characteristics of natural streams in the Blue Ridge, Piedmont, and upper Coastal Plain Physiographic Provinces of South Carolina: U.S. Geological Survey Water-Resources Investigations Report 90-4188, $92 \mathrm{p}$.

Zalants, M.G., 1991, Low-flow frequency and flow duration of selected South Carolina streams through 1987: U.S. Geological Survey Water-Resources Investigations Report 91-4170, 87 p. 


\section{Appendix 1. Explanation of Variables in the South Carolina Live-Bed Pier- and Contraction-Scour Database}

Data for this investigation have been compiled into a database, including photographs, observed scour depths, predicted scour depths, limited basin characteristics, limited soil data, and theoretical hydraulic data. The database can be viewed using Microsoft Access $^{\circledast}$ and is downloadable from http://pubs.usgs.gov/sir/2009/5099/. The South Carolina Live-Bed Pier- and Contraction-Scour Database (SCLBSD) provides automated forms that can be used to view data for a given site. The raw data also can be viewed in tabular format. Although most data for a given site can be viewed through the report formats, some data can only be viewed in the raw data tables. Blank data entries that appear in the reports or in raw data tables indicate that data are either not applicable or are missing. The following is a list and brief description of the automated forms that are in the SCLBSD.

1. Bridge Information - includes site location information, bridge length, construction history, bridge age, drainage area, and channel slope.

2. Live-Bed Contraction-Scour Data - includes field measurements of scour, predicted contraction scour for the maximum historic flow based on the HEC-18 equation (Richardson and Davis, 2001), variables used to compute predicted scour, and selected site information.

3. Live-Bed Pier-Scour Data - includes field measurements of scour, predicted pier scour for the maximum historic flow based on the HEC-18 equation (Richardson and Davis, 2001), variables used to compute predicted scour, and selected site information.

4. Photographs - includes photographs and captions for most sites.

There are three raw data tables in the SCLBSD; a brief description of each table and the associated variables follows. The headings for the following sections correspond with the table names in the database and are listed in alphabetical order. It should be kept in mind that hydraulic variables in the database are estimates obtained from the WSPRO (Shearman, 1990) model, and errors could exist within these estimates.

\section{Bridge_Information Table}

This table provides basic site information including bridge identification, location, limited basin characteristics data, construction dates, SCDOT bridge-plan file numbers, and bridge age. The variables are defined below.

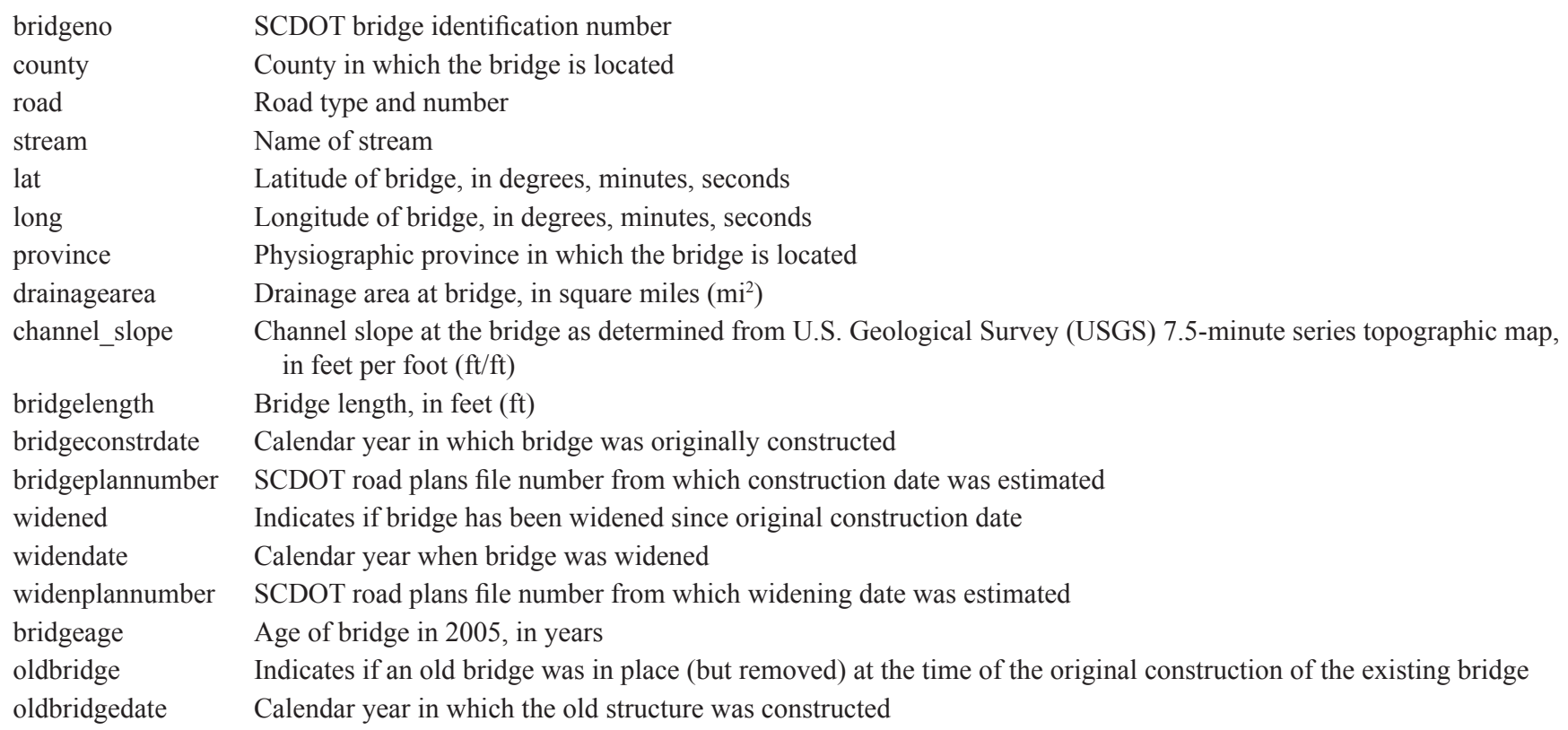




\section{Contraction_Scour Table}

This table includes field measurements of live-bed contraction scour, predicted contraction scour for the estimated maximum historic flow based on the HEC-18 equation (Richardson and Davis, 2001), variables used to compute predicted scour, and selected site information. For more details about the computation of contraction scour, refer to the "Predicted Live-Bed Contraction Scour" section of the report. The variables in the database table are briefly defined below.

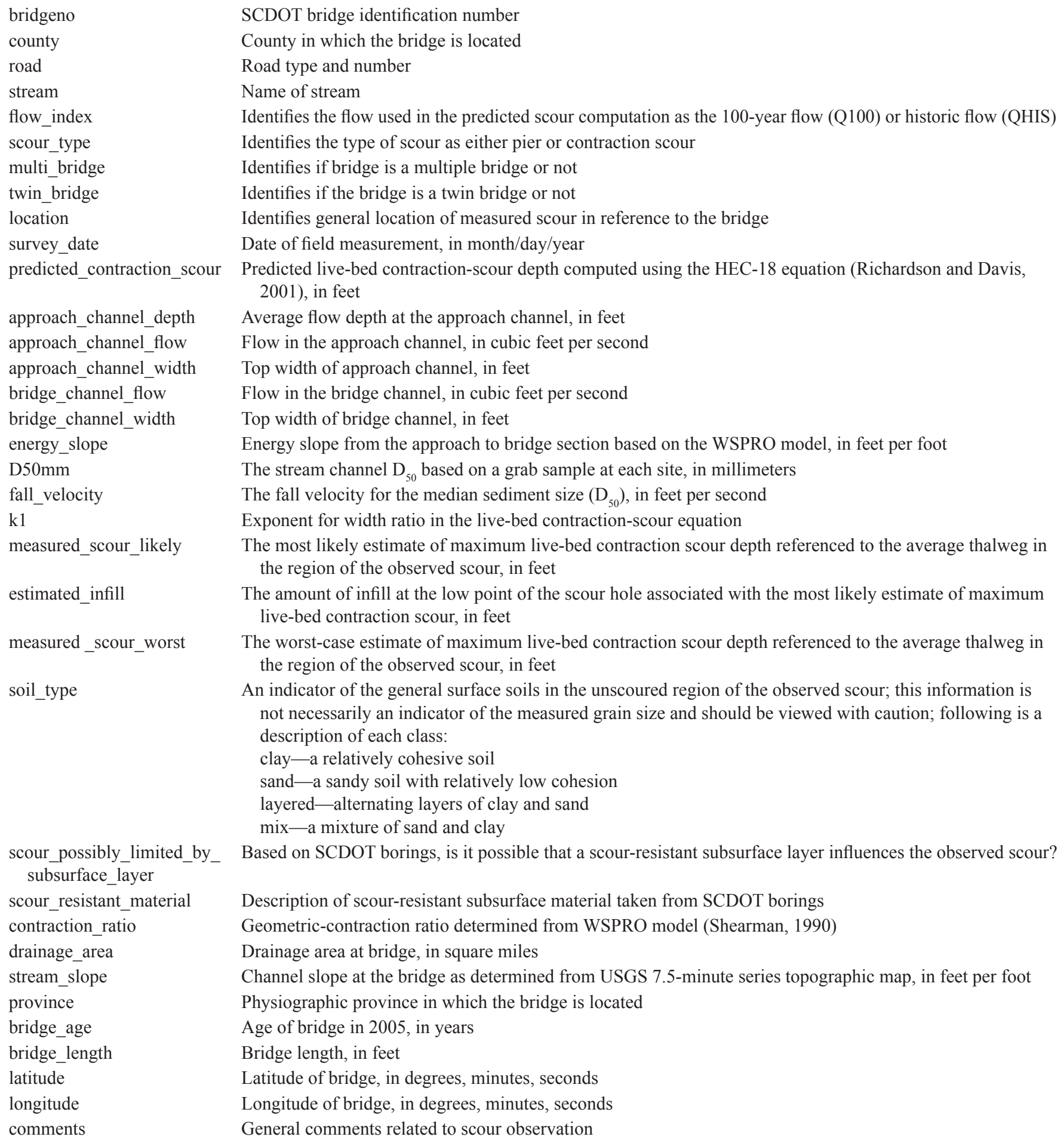




\section{Pier_Scour Table}

This table includes field measurements of live-bed pier scour, predicted pier scour for the estimated maximum historic flow based on the HEC-18 equation (Richardson and Davis, 2001), variables used to compute predicted scour, and selected site information. For more details about the computation of contraction scour, refer to the "Predicted Live-Bed Pier Scour" section of the report. The variables in the database table are briefly defined below.

bridgeno
county
road
stream
flow_index
scour_type
station
predicted_pier_scour
pier_flow_depth
pier_flow_velocity
pier_width
pier_length
skew_angle
$K_{1}$
$K_{2}$
$K_{3}$
$K_{4}$
pier_froude_number
multi_bridge
twin_bridge
bent_number
survey_date
measured_scour
pier_shape
pier_material
multi_column
number_columns
max_column_width
min_column_width
max_spacing
min_spacing
scour_hole_width
soil_type

D50mm

bridge_age

stream_slope

drainage_area

province

contraction_ratio

bridge_length

latitude

longitude
SCDOT bridge identification number

County in which the bridge is located

Road type and number

Name of stream

Identifies the flow used in the predicted scour computation as the 100-year flow (Q100) or historic flow (QHIS)

Identifies the type of scour as either pier or contraction scour

Station of pier from left end of bridge as determined by an observer looking downstream

Predicted live-bed contraction-scour depth computed using the HEC-18 equation (Richardson and Davis, 2001), in feet

Average approach flow depth at the pier, in feet

Approach flow velocity at the pier, in feet per second

Width of the pier, in feet

Length of the pier, in feet

The skew of the pier to the approaching flow, in degrees

The dimensionless correction factor for pier nose shape

The dimensionless correction factor for angle of attack

The dimensionless correction factor for bed conditions

The dimensionless correction factor for bed armoring

The approach flow Froude number

Identifies if bridge is a multiple bridge or not

Identifies if the bridge is a twin bridge or not

Identifies the bent number from the SCDOT plans

Date of field measurement, in month/day/year

Maximum live-bed pier-scour depth referenced to the average ground elevation at the top of the pier-scour hole in close proximity to the pier, in feet

Shape of the pier

Material from which pier is made

Identifies if pier has multiple columns

Number of columns in multiple-column pier

The largest column width in a multiple-column pier, in feet

The smallest column width in a multiple-column pier, in feet

The largest spacing between columns in a multiple-column pier, in feet

The smallest spacing between columns in a multiple-column pier, in feet

The width of the pier-scour hole perpendicular to flow

A subjective indicator of the general surface soils in the unscoured region of the observed scour; this information is not necessarily an indicator of the measured grain size and should be viewed with caution; following is a description of each class:

clay_a relatively cohesive soil

sand-a sandy soil with relatively low cohesion

layered - alternating layers of clay and sand

mix - a mixture of sand and clay

The stream channel $\mathrm{D}_{50}$ based on a grab sample at each site, in millimeters

Age of bridge in 2005, in years

Channel slope at the bridge as determined from USGS 7.5-minute series topographic map, in feet per foot

Drainage area at bridge, in square miles

Physiographic province in which the bridge is located

Geometric-contraction ratio determined from WSPRO model (Shearman, 1990)

Bridge length, in feet

Latitude of bridge, in degrees, minutes, seconds

Longitude of bridge, in degrees, minutes, seconds 

Appendix 2. South Carolina bridge-scour study sites and reference numbers for figure 2. (Note: At twin bridge crossings, only the structure number for the northbound or eastbound bridge is provided.)

[S-, Secondary Road; I, Interstate Highway; S.C., South Carolina Route; U.S., United States Route]

\begin{tabular}{|c|c|c|c|c|}
\hline $\begin{array}{c}\text { Reference } \\
\text { number } \\
\text { for figure } 2\end{array}$ & County & Road & Stream & $\begin{array}{c}\text { Structure } \\
\text { number }\end{array}$ \\
\hline 1 & Abbeville & S-32 & Little River & 017003200300 \\
\hline 2 & Aiken & I 20 & S. Edisto River & 021002021200 \\
\hline 3 & Aiken & I 20 & N. Edisto River & 021002021400 \\
\hline 4 & Aiken & S.C. 4 & S. Edisto River & 024000400200 \\
\hline 5 & Allendale & U.S. 301 & Salkehatchie River & 032030100800 \\
\hline 6 & Allendale & S.C. 3 & King Creek & 034000300100 \\
\hline 7 & Bamberg & U.S. 21 & Edisto River & 052002100100 \\
\hline 8 & Bamberg & U.S. 321 & S. Edisto River & 052032100500 \\
\hline 9 & Barnwell & U.S. 278 & Salkehatchie River & 062027800500 \\
\hline 10 & Calhoun & U.S. 601 & Congaree River & 092060100300 \\
\hline 11 & Chester & U.S. 21 & Rocky Creek & 122002100100 \\
\hline 12 & Chester & S.C. 72 & Sandy River & 124007200200 \\
\hline 13 & Chesterfield & U.S. 52 & Juniper Creek & 132005200200 \\
\hline 14 & Clarendon & S.C. 261 & Sammy Swamp & 144026100100 \\
\hline 15 & Colleton & S.C. 63 & Salkehatchie River & 154006300100 \\
\hline 16 & Darlington & I 95 & Black Creek & 161009510100 \\
\hline 17 & Darlington & U.S. 401 & Lynches River & 162040100100 \\
\hline 18 & Darlington & S.C. 34 & Black Creek & 164003400400 \\
\hline 19 & Dillon & I 95 & Little Pee Dee River & 171009510900 \\
\hline 20 & Dillon & U.S. 301 & Little Pee Dee River & 172030100400 \\
\hline 21 & Dillon & S.C. 9 & Little Pee Dee River & 174000900200 \\
\hline 22 & Dillon & S.C. 41 & Little Pee Dee River & 174004100200 \\
\hline 23 & Dorchester & U.S. 15 & Edisto River & 182001500100 \\
\hline 24 & Dorchester & S.C. 61 & Edisto River & 184006100100 \\
\hline 25 & Fairfield & U.S. 21 & Big Wateree Creek & 202002100400 \\
\hline 26 & Florence & U.S. 52 & Lynches River & 212005210400 \\
\hline 27 & Florence & U.S. 378 & Lynches River & 212037800900 \\
\hline 28 & Florence & S-26 & Black Creek & 217002600100 \\
\hline 29 & Greenville & S.C. 418 & Reedy River & 234041800200 \\
\hline 30 & Greenville & S-68 & Reedy River & 237006800100 \\
\hline 31 & Greenville & S-125 & Saluda River & 237012500100 \\
\hline 32 & Greenwood & U.S. 221 & Hard Labor Creek & 242022100200 \\
\hline 33 & Greenwood & S.C. 34 & Wilson Creek & 244003400100 \\
\hline 34 & Hampton & U.S. 601 & Coosawhatchie River & 252060100300 \\
\hline 35 & Hampton & U.S. 601 & Salkehatchie River & 252060100600 \\
\hline 36 & Hampton & S.C. 363 & Coosawhatchie River & 254036300100 \\
\hline 37 & Hampton & S-27 & Coosawhatchie River & 257002700100 \\
\hline 38 & Horry & U.S. 501 & Little Pee Dee River & 262050110100 \\
\hline 39 & Horry & S.C. 22 & Waccamaw River & 264002220100 \\
\hline
\end{tabular}


Appendix 2. South Carolina bridge-scour study sites and reference numbers for figure 2. (Note: At twin bridge crossings, only the structure number for the northbound or eastbound bridge is provided.) - Continued

[S-, Secondary Road; I, Interstate Highway; S.C., South Carolina Route; U.S., United States Route]

\begin{tabular}{|c|c|c|c|c|}
\hline $\begin{array}{c}\text { Reference } \\
\text { number } \\
\text { for figure } 2\end{array}$ & County & Road & Stream & $\begin{array}{c}\text { Structure } \\
\text { number }\end{array}$ \\
\hline 40 & Horry & S.C. 917 & Little Pee Dee River & 264091700100 \\
\hline 41 & Jasper & S-87 & Coosawhatchie River & 277008700100 \\
\hline 42 & Kershaw & U.S. 1 & Little Lynches River & 282000100500 \\
\hline 43 & Kershaw & U.S. 1 & Wateree River & 282000110200 \\
\hline 44 & Kershaw & S.C. 157 & Little Lynches River & 284015700100 \\
\hline 45 & Kershaw & S.C. 341 & Little Lynches River & 284034100100 \\
\hline 46 & Laurens & S.C. 560 & Little River & 304056000200 \\
\hline 47 & Laurens & S-36 & Reedy River & 307003600200 \\
\hline 48 & Laurens & S-102 & Little River & 307010200100 \\
\hline 49 & Laurens & S-112 & Enoree River & 307011200100 \\
\hline 50 & Laurens & S-263 & Enoree River & 307026300100 \\
\hline 51 & Lee & U.S. 15 & Scape Ore Swamp & 312001500400 \\
\hline 52 & Lee & U.S. 15 & Lynches River & 312001500500 \\
\hline 53 & Lee & U.S. 401 & Scape Ore Swamp & 312040100100 \\
\hline 54 & Lexington & I 77 & Congaree River & 321007710500 \\
\hline 55 & Marion & U.S. 76 & Little Pee Dee River & 342007600700 \\
\hline 56 & Marion & U.S. 76 & Great Pee Dee River & 342007620100 \\
\hline 57 & Marion & U.S. 378 & Great Pee Dee River & 342037800100 \\
\hline 58 & Marlboro & U.S. 1 & Great Pee Dee River & 352000110100 \\
\hline 59 & McCormick & S-85 & Hard Labor Creek & 337008500100 \\
\hline 60 & Newberry & S.C. 121 & Saluda River & 364012100101 \\
\hline 61 & Newberry & S-45 & Enoree River & 367004500100 \\
\hline 62 & Newberry & S-81 & Enoree River & 367008100200 \\
\hline 63 & Orangeburg & U.S. 301 & North Fork Edisto River & 382030100500 \\
\hline 64 & Pickens & S.C. 183 & Twelvemile Creek & 394018300400 \\
\hline 65 & Richland & I 20 & Broad River & 401002020100 \\
\hline 66 & Spartanburg & U.S. 29 & South Tyger River & 422002900100 \\
\hline 67 & Spartanburg & U.S. 221 & South Tyger River & 422022110300 \\
\hline 68 & Spartanburg & S.C. 146 & Enoree River & 424014600100 \\
\hline 69 & Spartanburg & S.C. 417 & South Tyger River & 424041700200 \\
\hline 70 & Spartanburg & S-62 & South Tyger River & 427006200500 \\
\hline 71 & Spartanburg & S-242 & South Tyger River & 427024200200 \\
\hline 72 & Union & S.C. 49 & Tyger River & 444004900100 \\
\hline 73 & Union & S.C. 49 & Fairforest Creek & 444004900200 \\
\hline 74 & Union & S.C. 72 & Tyger River & 444007200100 \\
\hline 75 & Union & S.C. 215 & Fairforest Creek & 444021500300 \\
\hline 76 & Union & S-16 & Tyger River & 447001600200 \\
\hline 77 & Union & S-16 & Fairforest Creek & 447001600300 \\
\hline 78 & Williamsburg & S.C. 41 & Black Mingo Creek & 454004100500 \\
\hline
\end{tabular}


Prepared by:

USGS Publishing Network

Raleigh Publishing Service Center

3916 Sunset Ridge Road

Raleigh, NC 27607

For additional information about this publication, contact:

Stephen T. Benedict, Hydrologist

USGS South Carolina Water Science Center

Field Headquarters

405 College Avenue, Suite 200

Clemson, SC 29631

email: benedict@usgs.gov

Or visit the USGS South Carolina Water Science Center Web site at: http://sc.water.usgs.gov/ 
